\title{
Análise dos parâmetros que interferem no metabolismo da microbiota anaeróbia e anóxica na remoção de bifenilas policloradas
}

VERSÃO CORRIGIDA

São Carlos, 2015 


\section{Análise dos parâmetros que interferem no metabolismo da microbiota anaeróbia e anóxica na remoção de bifenilas policloradas}

Tese apresentada à Escola de Engenharia de São Carlos da Universidade de São Paulo, como parte dos requisitos necessários para a obtenção do título de Doutora em Ciências: Engenharia Hidráulica e Saneamento

Orientadora: Profa. Dra. Maria Bernadete A. Varesche 
AUTORIZO A REPRODUÇÃO E DIVULGAÇÃO TOTAL OU PARCIAL DESTE TRABALHO, POR QUALQUER MEIO CONVENCIONAL OU ELETRÔNICO, PARA FINS DE ESTUDO E PESQUISA, DESDE QUE CITADA A FONTE.

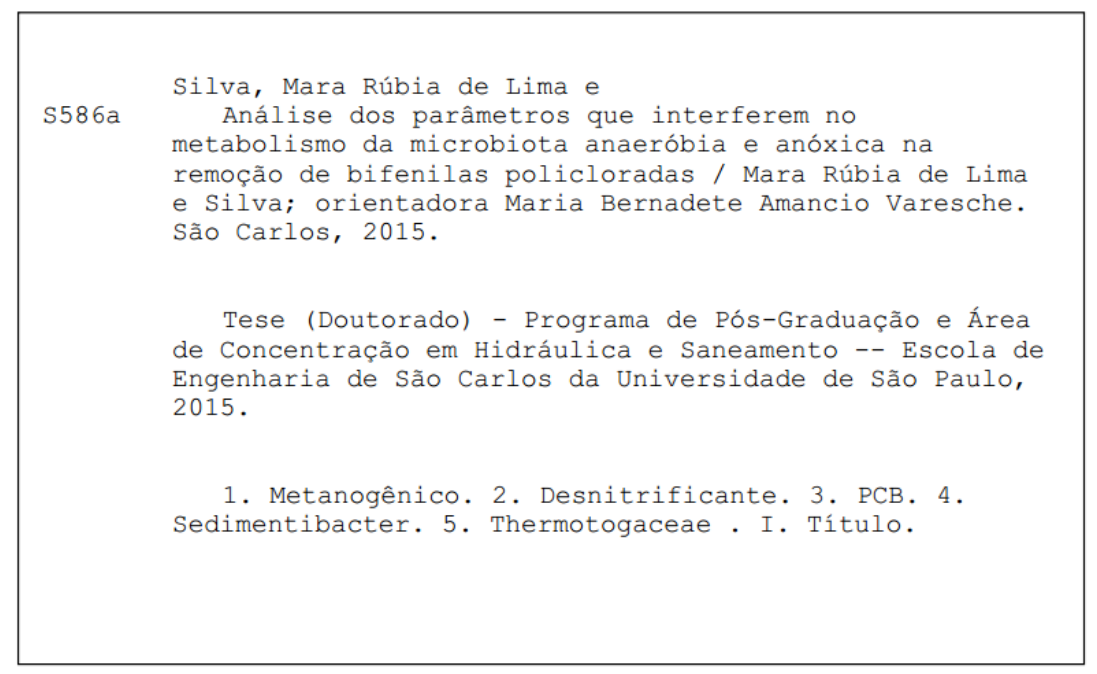




\section{FOLHA DE JULGAMENTO}

Candidata: Bacharela MARA RÚBIA DE UIMA E SILVA.

Titulo da tese: "Análise dos parâmetros que interferem no metabolismo da microbiota anaeróbia e anóxica na remoção de bifenilas policloradas".

Data da defesa: $24 / 09 / 2015$

Comissāo Julgadora:

Profa. Associada Maria Bernadete Amâncio Varesche (Orientadora)

(Escola de Engenharia de São Carlos/EESC)

Profa. Dra. Márcia Helena Rissato Zamariolli Damianovic (Escola de Engenharia de Sāo Carlos/EESC)

Prof. Dr. Álvaro José dos Santos Neło

(Instituto de Química de São Carlos/IQSC)

Prof. Dr. Gunther Brucha

(Universidade Federal de Alfenas/UNIFAL)

Profa. Dra. Kelly de Araújo Rodrigues Pessoa

(Instituto Federal de Educaçāo Ciência e Tecnologia do Ceará/IFECT)
Resultado:

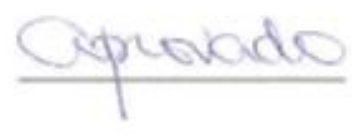

aperever APBOVADO

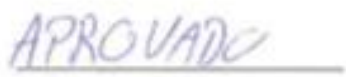

Coordenadora do Programa de Pós-Graduaçâo em Engenharia Hidráulica e Saneamento:

Profa. Associada Maria Bernadele A. Varesche Silva

Presidente da Comissão de Pós-Graduação:

Prof. Associado Paulo César Lima Segantine 
"Quando as crenças espiritas forem vulgarizadas, quando forem aceitas pelas massas, e, a, julgar pela rapidez. com que elas se propagam, esse tempo não estaria longe, ocorrerá com ela o que acorre com todas as ideias novas que encontraram oposição: os sábios se renderão à evidencia.

Eles a atingirão individualmente pela força das coisas. Até lá, é intempestivo desviá-los dos seus trabalhos especiais, para os constranger a se ocuparem de uma coisa estranha, que não está nem nas suas atribuições, nem em seu programa. À espera disso, aqueles que, sem um estudo prévio e aprofundado da matéria, se pronunciam pela negativa e zombam de quem não thes colhe a opinião, esquecem que o mesmo ocorreu na maioria das grandes descobertas que honram a Humanidade. Eles se expõem a ver seus

nomes aumentarem a lista dos ilustres proscriadores das ideias novas, $e$ inscrito as lado dos membros da douta assembleia que, em 1752, acolheram com uma imensa explosão de riso o relatório de Franklin sobre para-raios, julgando-o indigno de fissurar ao lado das comunicações que the eram endereçadas; e desse outro que ocasionou perder a França o beneficio da iniciativa da marinha a vapor, declarando o sistema de Fulton um sonho impraticável; e essas eram questões de sua alçada. Se, pois, essas assembleias que contavam em seu seio a elite dos sábios do mundo, não tiveram senão o escárnio e o sarcasmo por ideias que não compreendiam, e que alguns anos mais tarde deveriam revolucionar a Ciência, os costumes e a indústria, como esperar que uma questão estranha a seus trabalhos obtenha mais favor? Esses erros de alguns, lamentáveis por sua memória, não poderiam tirar-lhe os titulos que, por outras coisas, adquiriram a nossa estima, Mas é necessário um diploma oficial para ter bom senso e não se contam fora das poltronas acadêmicas senão tolos e imbecis?

Que se analisem os adeptos da Doutrina Espirita e se verá se nela não se encontram senão ignorantes, e se o número imenso de homens de mérito que a abraçaram permite se a relegue ao nivel das crenças populares. O caráter e o 
saber desses homens valem bem o que se disse: uma vez que eles afirmam, é preciso ao menos que haja alguma coisa.

Repetimos ainda que se os fatos que nos ocupam se encerrassem no movimento mecânico dos corpos, a procura da causa física desse fenômeno estaria no dominio da Ciência. Mas, desde que se trata de uma manifestação fora das leis da Humanidade, ela escapa da competência da ciência material, porque ela não pode exprimir nem por algarismos nem pela força mecânica. Quando surge um fato novo, que não compete a nenhuma ciência conhecida, o sábio, para estuda-lo, deve fažer abstração de sua ciência e dizer-se que é para ele um estudo novo, que não se pode fazer com ideias preconcebidas.

O homem que considera a sua razão infalivel está bem perto do erro; mesmo os que têm as ideias mais falsas se apoiam sobre sua razão e é em virtude disso que rejeitam tudo o que lhes parece impossivel. Os que outrora repeliram as admiráveis descobertas que a Humanidade se honra, faziam todo apelo a esse julgamento para as rejeitar."

Alan Kardec, Introdução Livros dos Espiritos 


\section{Agradecimentos}

Agradeço ao mundo espiritual pela minha conquista, pois nenhuma conquista é alcançada sozinha.

Agradeço a minha família que sempre me apoiou. Agradeço ao meu pai, que sei está me olhando e torcendo pelo meu sucesso.

Minha querida mãe, que mesmo longe, encontra diversas maneiras de demonstrar seu orgulho por mim.

Minhas irmãs que sempre me amaram e me apoiaram, principalmente, minha irmã Milena, que participou de todo o processo doloroso e fortificante do doutorado. Você sempre esteve do meu lado, e essa conquista é parte desse apoio.

Agradeço minha querida esposa, Elisa, que sofreu e aguentou como ninguém o peso desses anos. Mas por isso mesmo, a outra parte desse doutorado é devido a esse amor e suporte que você me oferece!

Meus queridos filhos de quatro patas, Brahma, Bolinha e Sócrates, que mesmo não entendendo por que a mamãe tinha que sair tão cedo e voltar tão tarde, me amou incondicionalmente.

Agradeço a Professora Maria Bernadete pela orientação, tanto no mestrado quando no doutorado.

Agradeço aos meu eternos amigos 2006/1. Que mesmo longe, eu torço por vocês e fico muito feliz pelas suas conquistas. E Agradeço pelas queridas Taninha, Suellen e professora Marines pela amizade e por fazerem parte de minha vida.

Aos Professores Marcelo Zaiat, Eugenio Foresti, Wiclef e Márcia Damianovick, exemplos de integridade, pela amizade e conversas agradáveis durante o cafezinho.

Ao apoio técnico de Carolina Sabatini, Eloisa Pozzi, Isabel Sakamoto e Maria Ângela Adorno, muito obrigada por estarem sempre dispostas a me ajudar nas etapas importantes de meu trabalho, com muita seriedade e competência.

Aos amigos Drica, Mari Carosia, Carlinha, professor Theo, Juliana e Fabrício pelas críticas construtivas e principalmente, pela amizade sem vocês minha vida em São Carlos seria muito séria!

Agradeço aos meus queridos amigos do LPB, que em tempos de desespero sempre tinham causos, teorias de como é a vida no doutorado e muita risada, por que zoeira never ends: Professor Dago, professor Paulo, Rachel, Priscila, Tiago Paladino, Tiagão, Eduardo, Lucas, Guilherme Vuitick, Guilherme Oliveira, Djalma, Marcus, Vanessa, Rodrigo Carneiro, Ana Flavia, Lívia, Regiane Ratti, Inaê, Cebola, Leandro, Inês, Tânia, Carol Gil, Laís, Thais.

Aos funcionários do SHS por estarem sempre prontos a ajudar, Sá, Priscila, Rose, Fernanda e André. Aos funcionários e técnicos do Campus 2, Silvana, Fernando, Juliana e Edson, muito gentis e dispostos a ajudar.

A Escola de Engenharia de São Carlos (EESC/USP) pela oportunidade de realização do doutorado.

A Cnpq pela concessão da bolsa de doutorado e apoio financeiro. 


\section{Resumo}

SILVA, M. R. de L. e (2015). Análise dos parâmetros que interferem no metabolismo da microbiota anaeróbia e anóxica na remoção de bifenilas policloradas. $210 \mathrm{f}$. Tese (Doutorado) Escola de Engenharia de São Carlos, Universidade de São Paulo, São Carlos. 2015.

A elevada concentração de cloro das bifenilas policloradas provoca alta toxicidade do composto, o qual dificulta sua biodegradação. A contaminação de PCB no Brasil foi confirmada em estudo realizado na Bahia de Santos-São Vicente (São Paulo), o qual revelou a necessidade de um plano de ação para o controle e remoção de PCB no Brasil. Pretendeu-se assim, na realização da presente pesquisa, verificar quatro hipóteses: (1) A técnica de Microextração em fase sólida é uma metodologia eficaz para avaliação de bifenilas policloradas de amostras de reatores; (2) A condição fermentativametanogênica abriga comunidade resistente ao PCB, e removê-lo; (3) A condição desnitrificante abriga comunidade resistente ao PCB, e removê-lo e (4) A remoção de PCB, bem como, a composição microbiana é distinta em cada condição metabólica. Para tanto, reatores em batelada foram montados separadamente com biomassa anaeróbia proveniente de reator UASB usado no tratamento de água residuária de avicultura e biomassa de sistemas de lodos ativados de tratamento de esgoto sanitário. Os reatores operados em condição mesófila foram alimentados com meio sintético, co-substratos, sendo etanol (457 mg. $\left.\mathrm{L}^{-1}\right)$ e formiato de sódio $\left(680 \mathrm{mg} . \mathrm{L}^{-1}\right)$ para os reatores anaeróbios, e somente etanol (598 mg. $\mathrm{L}^{-1}$ ) para os reatores anóxicos, além de PCB padrão Sigma (congêneres PCBs 10, 28, 52, 153, 138 e 180) em diferentes concentrações, dependendo do objetivo do ensaio. A aplicação do método de extração por SPME com análise em cromatógrafo gasoso com detector por captura de elétrons foi adequada para a determinação dos seis congêneres de PCB. Obteve-se ampla faixa de linearidade, seletividade frente aos vários interferentes, além da robustez do método, utilidade e confiabilidade na identificação e quantificação específica dos seis congêneres de PCB. A Hipótese 1 foi aceita; ou seja, por meio da aplicação da metodologia SPME foi possível quantificar os PCB nos reatores em batelada. Apesar de ter sido comprovada a inibição metanogênica na presença de PCB, com $\mathrm{IC}_{50}$ de $0,03 \mathrm{mg} . \mathrm{L}^{-1}$ (concentração na qual $50 \%$ da atividade metanogênica é inibida), a partir da análise dos reatores metanogênicos no Ensaio de Remoção, foi confirmada a remoção de $0,92 \mathrm{mg} . \mathrm{L}^{-1}, 0,19 \mathrm{mg} . \mathrm{L}^{-1}, 0,18$ mg.L $\mathrm{L}^{-1}, 0,07 \mathrm{mg} . \mathrm{L}^{-1}, 0,55 \mathrm{mg} . \mathrm{L}^{-1}$ e $0,47 \mathrm{mg} . \mathrm{L}^{-1}$ para os PCBs 10, 28, 52, 153, 138 e 180, respectivamente, para 1,5 mg.L $\mathrm{L}^{-1}$ inicial. Thermotogaceae, Sedimentibacter, Anaerolinaceae e Pseudomonas, foram identificadas nos reatores anaeróbios por meio da plataforma Illumina. Representantes de Thermotogaceae e Sedimentibacter foram identificados em sistemas com elevada taxa de remoção de PCB, e representantes do filo Chloroflexi (grupo no qual representantes da Anaerolineae estão inseridos) foram os primeiros microrganismos desalogenadores de PCB identificados. Assim a Hipótese 2 foi aceita; ou seja, por meio de ensaios em batelada foi comprovada a toxicidade do PCB sobre a comunidade anaeróbia, a alteração da composição microbiana influenciada pela presença de PCB e a remoção nesta condição. Verificou-se ainda que na presença de PCB ocorreu a desnitrificação e comparando-se diferentes relações $\mathrm{C} / \mathrm{N}_{-} \mathrm{NO}_{3}{ }^{-}$, foi estipulado a relação 6,95 como ideal na presença de PCB. Mesmo sendo confirmada a inibição da comunidade anóxica na presença de PCB com IC $\mathrm{I}_{50}$ de 1,0 mg. $\mathrm{L}^{-1}$, verificou-se remoção de 1,02 mg. $\mathrm{L}^{-1}, 0,85 \mathrm{mg} . \mathrm{L}^{-1}, 1,31 \mathrm{mg} . \mathrm{L}^{-1}, 1,02 \mathrm{mg} . \mathrm{L}^{-1}, 0,03 \mathrm{mg} . \mathrm{L}^{-1}$ e 0,09 mg. $\mathrm{L}^{-1}$ para os PCBs $10,28,52,153,138$ e 180, respectivamente, para 1,5 mg.L $\mathrm{L}^{-1}$ inicial. Bactérias semelhantes a Aeromonadaceae, Lutispora, Sedimentibacter e Thermotogaceae foram identificadas nos reatores desnitrificantes. Representantes de Aeromonadaceae e Lutispora estão relacionados com o metabolismo desnitrificante e representantes de Thermotogaceae e Sedimentibacter foram identificados em sistemas com elevada taxa de remoção de PCB. A Hipótese 3 foi também aceita; ou seja, por meio de ensaios em batelada foi calculada a relação $\mathrm{C} / \mathrm{N}-\mathrm{NO}_{3}{ }^{-}$ideal na presença de $\mathrm{PCB}$ e foi comprovada a 
toxicidade do PCB sobre a comunidade anóxica, a alteração da composição microbiana influenciada pela presença de PCB e a remoção nesta condição. A maior remoção de PCB foi verificada para a condição anaeróbia (entre $45 \%$ a 100\%), quando comparada com a condição anóxica (entre 10\% a 95\%). Bactérias semelhantes a Sedimentibacter e pertencentes a família Thermotogaceae foram identificadas nas duas condições nutricionais. Entretanto, mesmo verificando-se elevada abundancia relativa desses grupos nos reatores, evidenciou-se distinção entre as biomassas em cada condição. Assim, a Hipótese 4 foi aceita; ou seja, por meio de ensaios em batelada foi comprovada maior eficiência de remoção sob condição anaeróbia e distinta composição microbiana em cada condição.

Palavras-chave: Metanogênico, Desnitrificante, PCB, Sedimentibacter, Thermotogaceae 


\begin{abstract}
SILVA, M. R. de L. e (2015). Analysis of the parameters that affect the metabolism of microorganisms in the anaerobic and anoxic removing polychlorinated biphenyls. $210 \mathrm{p}$. Thesis (Ph.D.) - School of Engineering of São Carlos, University of São Paulo, São Carlos. 2015.

The high chlorine concentration in polychlorinated biphenyls improves its toxicity, complicating their biodegradation. A study conducted in Santos-São Vicente Bay (São Paulo) confirmed the PCB contamination in Brazil and reveled the need of an action plan to control e remove the PCB in Brazil. In this sense the aim of this study was to evaluate four hypotheses: (1) The Solid Phase Micro Extraction is an efficient methodology to evaluate biphenyl polychlorinated in reactors; (2) The fermentative-methanogenic microorganisms are resistant to PCB and capable to consume it; (3) The denitrifying microorganisms are resilient to the PCB and capable to remove it; (4) The PCB removal, as well the microbial composition is distinct in each condition. Therefore, batch reactors were operated separately inoculated with anaerobic biomass from UASB reactor treating poultry wastewater and biomass from activated sludge treating sewage wastewater. The reactors were feed with synthetic medium, co-substrates, as ethanol (457 mg. $\left.\mathrm{L}^{-1}\right)$ and sodium formate $\left(680 \mathrm{mg} . \mathrm{L}^{-1}\right)$ for the anaerobic reactors, and ethanol $\left(598 \mathrm{mg} . \mathrm{L}^{-1}\right)$ for the anoxic reactors and different concentrations of six congeners of PCB (PCBs 10, 28, 52, 153, 138 and 180) depending on the aim of the assay. The applicability of SPME technique in gas chromatography with electrons capture detection was attested in the analysis of six PCB congeners. Higher linearity, selectivity, accuracy, reproducibility and robustness was obtained in the PCB quantification analyses. The Hypothesis 1 was accepted; since the PCB congeners in the reactors were quantified by the SPME methodology. Although the PCB causes methanogenic inhibition, with $\mathrm{IC}_{50}$ of $0.03 \mathrm{mg} . \mathrm{L}^{-1}$ (concentration in which $50 \%$ of the methanogenic metabolism is inhibited), by the Removal Assay was confirmed the anaerobic removal of $0.92 \mathrm{mg} . \mathrm{L}^{-1}, 0.19 \mathrm{mg} . \mathrm{L}^{-1}, 0.18 \mathrm{mg} . \mathrm{L}^{-1}, 0.07$ mg.L $\mathrm{L}^{-1}, 0.55 \mathrm{mg} . \mathrm{L}^{-1}$ and $0.47 \mathrm{mg} . \mathrm{L}^{-1}$ to PCB $10,28,52,153,138$ and 180 , respectively, for $1.5 \mathrm{mg} . \mathrm{L}^{-1}$ initial. By means of platform Illumina Thermotogaceae, Sedimentibacter, Anaerolinaceae and Pseudomonas, were identified in the anaerobic reactors. The Thermotogaceaeand Sedimentibacter were related to systems with high PCB removal and the Chloroflexi members (Anaerolineae phylum) were the first PCB-dechlorination microorganisms identified. Therefore, the Hypothesis 2 was accepted since the PCB leads to anaerobic inhibition and in the reactors were verified the PCB removal and changes in the microbial composition. Even with $\mathrm{PCB}$, the denitrification metabolism occurs and evaluating different $\mathrm{C} / \mathrm{N}-\mathrm{NO}_{3}{ }^{-}$relations, the 6.95 was stipulated the ideal in the presence of PCB. Even though the PCB causes inhibition in the denitrification bacteria, with $\mathrm{IC}_{50}$ of $1.0 \mathrm{mg} . \mathrm{L}^{-1}$, by the Removal Assay in the denitrifying reactors, was confirmed the anoxic removal $1.02 \mathrm{mg} . \mathrm{L}^{-1}, 0.85 \mathrm{mg} . \mathrm{L}^{-1}, 1.31$ mg.L $\mathrm{L}^{-1}, 1.02 \mathrm{mg} . \mathrm{L}^{-1}, 0.03 \mathrm{mg} . \mathrm{L}^{-1}$ and $0.09 \mathrm{mg} . \mathrm{L}^{-1}$ to PCB 10, 28, 52, 153, 138 and 180, respectively, for $1.5 \mathrm{mg} . \mathrm{L}^{-1}$ initial. Aeromonadaceae, Lutispora, Sedimentibacter and Thermotogaceae were identified in the denitrifying reactors. Members of Aeromonadaceae e Lutispora were related to the denitrification metabolism and Thermotogaceae e Sedimentibacter were identified in systems with high PCB removal rate. The Hypothesis 3 was accepted since the PCB leads to anoxic inhibition and in the reactors were verified the PCB removal and changes in the microbial composition. The anaerobic reactors presented the higher PCB removal percentage (between $45 \%$ and 100\%) when compared to the anoxic reactors (between 10\% and 95\%). Member of Sedimentibacter and Thermotogaceae were identifyied in both conditions. However, even with high relative abundance of these two groups in the reactors, it was shown distinct composition in each biomass. Thus, the Hypothesis 4 was accepted since the PCB removal was more efficient in the anaerobic condition and were verified different changes in the microbial composition in each condition.
\end{abstract}

Palavras-chave: Methanogenic, Denitrifying, PCB, Sedimentibacter, Thermotogaceae 


\section{LISTA DE ABREVIATURAS}

$\begin{array}{ll}\% \mathrm{I}_{\mathrm{D}}: & \text { Inibição desnitrificante } \\ \% \mathrm{I}_{\mathrm{M}}: & \text { Inibição metanogênica }\end{array}$

ATA: $\quad$ Análise de toxicidade anaeróbia (Anaerobic Toxicity Assay)

BphA: enzima 2,3-dioxigenase

BphB: enzima dihidrodiol desidrogenase

BphC: $\quad$ enzima 2,3-dihidroxibifenil dioxigenase

BphD: $\quad$ enzima hidrolase

CAR/PDMS: Carboxen/Polydimethylsiloxane ou Carboxen/Polidimetilsiloxano

CLAE: $\quad$ Cromatografia Líquida de Alta Eficiência

CG-ECD: Cromatógrafo Gasoso com Detector com captura de Elétrons

CV: $\quad$ Coeficiente de variação

CW/DVB: Carbowax/Divinylbenzene ou Carbowax/Divinilbenzeno

DCE: dicloroetano

DQO: $\quad$ Demanda Química de Oxigênio

$\mathrm{E}_{\mathrm{D}}$ : $\quad$ Eficiência de desnitrificação

IUPAC: $\quad$ International Union of Pure and Applied Chemistry

$\mathrm{NaCl}: \quad$ Cloreto de sódio

$\mathrm{NO}_{3}{ }^{-}: \quad$ Íon Nitrato

$\mathrm{NO}_{2}^{-:} \quad$ Íon Nitrito

$\mathrm{NO}_{\mathrm{x}}{ }^{-}: \quad$ Íons Nitrato e Nitrito

PCB: $\quad$ Bifenila policlorada

PDMS: Polydimethylsiloxane ou Polidimetilsiloxano

PDMS/DVB: Polydimethylsiloxane/Divinylbenzene ou Polidimetilsiloxano/ divinilbenzeno

pH: potencial hidrogênionico

SPE: $\quad$ Solid-phase extraction ou Extração em fase sólida 
SPME: $\quad$ Solid-phase Microextraction ou Microextração em fase Sólida

SPME $E_{H S}$ Microextração em fase Sólida por meio do headspace

SPMEi: $\quad$ Microextração em fase Sólida imersa no líquido

SSV: $\quad$ Sólidos suspensos voláteis

STV: $\quad$ Sólidos totais voláteis

TCE: $\quad$ tricloroetano

UASB: $\quad$ Upflow Anaerobic Sludge Blanket ou Reator anaeróbio de manta de lodo de fluxo ascendente

UTO: $\quad$ Unidade Taxonômica Operacional 


\section{LISTA DE FIGURAS}

Figura 3-1. (a) Estruturas da bifenila; (b) PCB 138 (2,2',3,4,4',5'-hexaclorobifenila) 7

Figura 3-2 Rota de biodegradação aeróbia do bifenil e PCB com baixo teor de cloro. (1) Bifenil/ PCB; (2) cis 2,3-dihidroxibifenil; (3) 2,3-dihidroxibifenil; (4) ácido 2-hidroxi-6-oxo-6-fenilexa-2,4- dienóico; (5) ácido 2-hidroxipent-2,4- dienóico; (6) ácido benzoico/ clorobenzóico. bphA: bifenil 2,3-dioxigease; bphB: cis-2,3-dihidroxibifenil desidrogenase; bphC: 2,3-dihidroxibifenil 1,2-dioxigenase; bphD: 2hidroxi-6-oxo-6-fenilexa-2,4-dienoato hidrolase.

Figura 3-3. Representação genérica da reação de desalogenação catalisada por microrganismos. .............13

Figura 3-4 Desalogenação anaeróbia redutiva de 2,3,4,5,6-pentaclorobifenil. (a) Desalogenação redutiva na posição meta mediada por Dehalococcoides ethenogenes 195. (b) Desalogenação na posição orto mediada pela bactéria 0-17.

Figura 3-5 Desnitrificação completa ou redução de nitrato a nitrogênio gasoso. ........................................19

Figura 4-1 Fluxograma experimental dos ensaios em batelada, extração do PCB e caracterização da comunidade microbiana

Figura 4-2 Amostrador e fibras utilizadas para a extração do PCB por meio da técnica de SPME. (a) amostrador manual; (b) Fibra exposta do amostrador; (c) Frasco para amostrador automático por headspace; (d) aparato para extração do PCB; (e) amostrador acoplado ao Cromatógrafo gasoso; (f) Fibras testadas, PDMS/DVB (azul), PDMS (vermelha) e carboxen/PDMS (preta); (g) Caixa de fibras testadas.

Figura 4-3 Fluxograma da etapa de sequenciamento massivo das amostras. ..............................................41

Figura 4-4 Reatores em batelada e agitador elétrico utilizados nos ensaios em batelada. (a) reator em batelada com meio sintético, co-substrato, PCB e inóculo utilizados em todos os ensaios; (b) espuma de poliuretano, evidenciando a biomassa aderida no material suporte utilizada apenas no ensaio de Inibição Metanogênica e (c) agitador elétrico utilizado operação dos reatores........................................ 44

Figura 4-5 Fluxograma do Ensaio de Inibição Metanogênica ................................................................45

Figura 4-6 Etapas do Ensaio de Inibição Desnitrificante...........................................................................550

Figura 5-1 Análise da seletividade da extração por meio da técnica de SPME. (a) Cromatograma da análise da matriz isenta de PCB (Tempo de extração 15 minutos, temperatura ambiente de extração); (b) matriz adicionada de PCB (0,2 mg.L ${ }^{-1}$ PCB, tempo de extração 15 minutos, temperatura ambiente de extração). PCB 10 (Pico 1), PCB 28 (Pico 2), PCB 52 (Pico 3), PCB 153 (Pico 4), PCB 138 (Pico 5) e PCB 180 (Pico 6).

Figura 5-2 Área cromatográfica de cada congênere de PCB em diferentes concentrações de NaCl na extração por SPME

Figura 5-3 Cromatogramas dos seis congêneres de PCB com diferentes tipos de fibras na extração por meio da técnica de SPME, (a) Carboxen/PDMS, (b) PDMS/DVB e (c) PDMS. PCB 10 (Pico 1), PCB 28 (Pico 2), PCB 52 (Pico 3), PCB 153 (Pico 4), PCB 138 (Pico 5) e PCB 180 (Pico 6). .........................58

Figura 5-4 Área cromatográfica de cada congênere de PCB com extração sob diferentes tipos de fibras (PDMS, PDMS/DVB e Carbox/PDMS) utilizando a técnica de SPME.

Figura 5-5 Área cromatográfica de cada congênere de PCB (1,5 mg. $\left.\mathrm{L}^{-1}\right)$ em 5, 15 e 30 minutos de extração com a técnica de SPME.

Figura 5-6 Perfil cromatográfico de congêneres de PCB em diferentes tempos de extração. (a) perfil cromatográfico para 5 minutos com $1,5 \mathrm{mg} . \mathrm{L}^{-1}$, (b) perfil cromatográfico para 15 minutos com 1,5 mg.L ${ }^{-1}$, (c) perfil cromatográfico para 30 minutos com 1,5 mg.L ${ }^{-1}$. PCB 10 (Pico 1), PCB 28 (Pico 2), PCB 52 (Pico 3), PCB 153 (Pico 4), PCB 138 (Pico 5) e PCB 180 (Pico 6).

Figura 5-7 Perfis cromatográficos em diferentes temperaturas de dessorção: (a) $210^{\circ} \mathrm{C}$, (b) $250^{\circ} \mathrm{C}$ e (c) $280^{\circ} \mathrm{C}$ com 1,5 mg. $\mathrm{L}^{-1}$ de PCB na extração pela técnica de SPME. PCB 10 (Pico 1), PCB 28 (Pico 2), PCB 52 (Pico 3), PCB 153 (Pico 4), PCB 138 (Pico 5) e PCB 180 (Pico 6).

Figura 5-8 Área cromatográfica referente a dessorção a $210^{\circ} \mathrm{C}, 250^{\circ} \mathrm{C}$ e $280^{\circ} \mathrm{C}$ para 1,5 mg.L ${ }^{-1}$ de PCB... 65 
Figura 5-9 Área cromatográfica de cada congênere de PCB extraído com a técnica de SPME com diferentes volumes amostrais $(2,0,2,5$ e 3,0 mL): (a) área cromatográfica de cada congênere nos diferentes volumes amostrais para 0,09 mg. $\mathrm{L}^{-1} \mathrm{de} \mathrm{PCB}$, (b) área cromatográfica de cada congênere nos diferentes volumes amostrais para $1,5 \mathrm{mg}^{-\mathrm{L}^{-1}}$ de PCB.

Figura 5-10 Determinação gráfica das curvas de linearidade da técnica de SPME para os congêneres PCB 10; PCB 28; PCB 52; PCB 153; PCB 138 e PCB 180. Estão apresentados os valores da equação da reta, $\mathbf{R}^{2}$, LQ e LD de cada congênere. Símbolos representam dados, enquanto linha representa o ajuste da reta que representa a curva de calibração.

Figura 5-11 A precisão inter-dia através da área cromatográfica e coeficiente de variação entre as análises realizadas em dias distintos ( $\square$ dia 1 e đ dia 2) para os seis congêneres de PCB avaliados pela técnica de SPME.

Figura 5-12 Produção acumulada de metano para (a) RC e (b) R3,0 em ambos os ensaios (primeiro - $\mathrm{m}$ - e

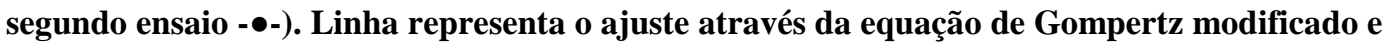
símbolos representam os dados.

Figura 5-13 Produção de metano nos reatores metanogênicos sob diferentes concentrações de PCB. RC: reator controle (sem PCB); R0,5: 0,5 mg.L $\mathrm{L}^{-1}$ de PCB; R1,5: 1,5 mg.L $\mathrm{L}^{-1}$ de PCB; R3,0: 3,0 mg.L $\mathrm{L}^{-1}$ de PCB; R4,5: 4,5 mg.L $\mathrm{L}^{-1}$ de PCB e R6,0: 6,0 mg. $\mathrm{L}^{-1}$ de PCB. $\mathrm{R}^{2}$ é o coeficiente de correlação, PMM a Produção Máxima Especifica de Metano $\left(\mu \mathrm{molCH}_{4} . \mathrm{gSTV}^{-1}\right)$ e VPM a velocidade de produção de metano $\left(\mu \mathrm{molCH}_{4} \cdot \mathrm{gSTV}^{-1} \cdot \mathrm{h}^{-1}\right)$. Símbolos representam valores medidos, enquanto linha representa o ajuste a equação modificada de Gompertz.

Figura 5-14 Proporção de cada ácido orgânico volátil no meio sintético (meio sintético mais fontes de carbono) e nos reatores $\mathrm{RC}$ (reator controle), R0,5 (reator com 0,5 mg. $\mathrm{L}^{-1}$ de PCB), R1,5 (reator com 1,5 mg.L $\mathrm{L}^{-1}$ de PCB), R3,0 (reator com 3,0 mg.L $\mathrm{L}^{-1}$ de PCB), R4,5 (reator com 4,5 mg.L $\mathrm{L}^{-1}$ de PCB) e R6,0 (reator com 6,0 mg.L ${ }^{-1}$ de PCB).

Figura 5-15. Relação entre porcentagem de inibição (-匹-) e produção máxima de metano (-匹-) versus a concentração de PCB. Símbolo representa dados mensurados e linha representa o ajuste dos dados à equação.

Figura 5-16 Perfis de DGGE de comunidades microbianas em RC (reator controle), i (inóculo), R0.5 (0,5 mg.L ${ }^{-1}$ de PCB), R1.5 (1,5 mg.L ${ }^{-1}$ de PCB), R3.0 (3,0 mg.L ${ }^{-1}$ de PCB), R4.5 (4,5 mg.L $\mathrm{L}^{-1}$ de PCB) e R6.0 (6,0 mg. $\mathrm{L}^{-1}$ de PCB) para o Domínio Archaea (a) e Bacteria (b). Dendrogama construído utilizando correlação de Pearson e o método de agrupamento UPGMA.

Figura 5-17 Produção específica de metano no Ensaio de Remoção de PCB. Ajuste de Gompertz modificado. Símbolos representam valores medidos, enquanto linha representa o ajuste da equação.

Figura 5-18 Proporção de cada ácido orgânico volátil nos reatores MT0 (reator metanogênico no tempo inicial), MT1 (reator metanogênico em 81 dias de operação), MT2 (reator metanogênico em 101 dias de operação), CMT0 (reator controle metanogênico no tempo inicial), CMT1 (reator controle metanogênico em 81 dias de operação) e CMT2 (reator controle metanogênico em 101 dias de operação)

Figura 5-19 Concentração dos seis congêneres de PCB (PCB 10, 28, 52, 153, 138 e 180) e concentração média dos PCBs (— PCBs totais) nos reatores metanogênicos (M) ao longo do tempo de operação

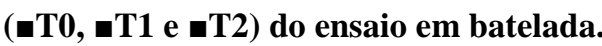

Figura 5-20 Curva de rarefação das sequencias de amostras do inóculo, reator metanogênico no tempo incial (-MT0) e final de operação (-MT2) (97\% de similaridade).

Figura 5-21 Abundância relativa de classes, dentro do grupo Proteobacteria, e dos filos (similaridade 97\%) nas amostras iniciais MT0 (a) e finais MT2 (b)

Figura 5-22 Distribuição da abundância relativa dos 10 grupos mais abundantes no início (-MT0) e no final (-MT2) da operação dos reatores $(97 \%$ de similaridade). (O) representa a classificação em nível de Ordem, (F) representa a classificação em nível de Família, (G) representa a classificação em nível de Gênero e (E) em nível de Espécie. 
Figura 5-23. Microscopia óptica comum da biomassa inativada por meio de tratamento térmico do lodo anaeróbio nos reatores controle metanogênico (CMT0 e CMT2). (a) filamentosa no reator CMT0, (b) massa amorfa resultante da inativação da biomassa do reator CMT0, (c) filamentosa da biomassa do reator CMT2, (d) cocos na biomassa do reator CMT2 depois da inativação por meio de tratamento térmico.

Figura 5-24. Microscopia óptica comum da biomassa do lodo anaeróbio proveniente dos reatores metanogênicos (MT0 e MT2). (a) e (b) bacilos nos reatores MT0, (c) bacilos envoltos em bolhas inertes na amostra MT0, (d) filamentosas na amostra MT2, (e) e (f) morfologia semelhantes a Methanosarcina na amostra MT2.

Figura 5-25 Análise de cluster (Correlação de Pearson) do perfil de bandas do PCR/DGGE para o (a) Domínio Bacteria e (b) Archaea para as amostras reatores metanogênico no início (MT0), no meio (MT1) e final da operação (MT2), bem como para os reatores controle no início (CMT0), no meio (CMT1) e final da operação (CMT2).

Figura 5-26 Concentração de PCB versus DQO.

Figura 5-27 Concentração de nitrato para as relações C-DQO/N-NO3 de 138:1 (- - -), de 6,6:1 (-ロ-), de 3,5:1 (-๑-) e de 1,8:1 (- $\triangle$-) na presença de PCB (1,5 mg. $\left.\mathrm{L}^{-1}\right)$. Símbolos representam os dados mensurados e a linha o ajuste a equação exponencial de decaimento.

Figura 5-28 Proporção de ácidos orgânicos voláteis no meio sintético mais fonte de carbono, nos reatores no tempo inicial (T0) e final (TF) de operação para as diferentes relações de $\mathrm{C} / \mathrm{N}-\mathrm{NO}_{3}{ }^{-}$................... 108

Figura 5-29 Relação $\mathrm{C} / \mathrm{N}$ ideal determinado pelo método de $\mathrm{NO}_{3}$ residual. 109

Figura 5-30 Relação entre porcentagem de inibição versus a concentração de PCB. Símbolo representa os dados e linha o ajuste à equação.

Figura 5-31 Proporção de cada ácido orgânico volátil nos reatores RC (reator controle), R0,5 (reator com 0,5 mg.L $\mathrm{L}^{-1}$ de PCB), R1,5 (reator com 1,5 mg.L $\mathrm{L}^{-1}$ de PCB) e R3,0 (reator com 3,0 mg.L $^{-1}$ de PCB).. 112

Figura 5-32 Perfis de DGGE de comunidades microbianas em RC (reator controle), i (inóculo), R0.5 (0,5 mg. $\mathrm{L}^{-1}$ de PCB), R1.5 (1,5 mg.L ${ }^{-1}$ de PCB) e R3.0 (3,0 mg.L ${ }^{-1}$ de PCB) para o Domínio Bacteria. Dendrogama construído utilizando correlação de Pearson e o método de agrupamento UPGMA... 113

Figura 5-33 Proporção de cada ácido orgânico volátil nos reatores DT0 (reator desnitrificante no tempo 0 dias), DT1 (reator desnitrificante no tempo 78 dias), DT2 (reator desnitrificante no tempo 99 dias), CDT0 (reator controle desnitrificante no tempo 0 dias), CDT1 (reator controle desnitrificante no tempo 78 dias) e CDT2 (reator controle desnitrificante no tempo 99 dias).

Figura 5-34 Concentração dos seis congêneres de PCB (PCB 10, 28, 52, 153, 138 e 180) e concentração média dos PCBs ( ( PCBs totais) nos reatores desnitrificantes (D) ao longo do tempo de operação

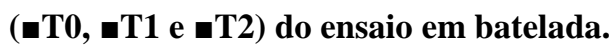

Figura 5-35 Curva de rarefação definida das sequencias de amostras do inóculo, ou reator desnitrificante no tempo incial (-DT0) e tempo final (-DT2) (97\% de similaridade).

Figura 5-36 Abundância relativa dos filos e classes do grupo de Proteobacteria (similaridade 97\%) nas amostras iniciais DT0 (a) e finais DT2 (b).

Figura 5-37 Distribuição da abundância relativa dos 10 grupos mais abundantes no início ( $\mathrm{DT}$ T) e no final (घDT2) da operação dos reatores (97\% de similaridade). (F) representa a classificação em nível de Família, (G) representa a classificação em nível de Gênero e (E) em nível de Espécie.

Figura 5-38. Microscopia óptica comum da biomassa de lodos ativados utilizado para inoculação nos reatores DT0 e DT2. (a) morfologia semelhante a Euglypha nos reatores DT0, (b) ovos de rotíferos nos reatores DT0, (c) morfologia semelhante a fungo filamentoso na amostra DT0, (d) morfologia semelhante a fungo filamentoso septado na amostra DT0, (e) morfologia semelhante a fungo filamentoso na amostra DT2, (e) cocos (estreptococos) na amostra DT2.

Figura 5-39. Microscopia óptica comum da biomassa inativada por meio de tratamento térmico da biomassa anóxica proveniente dos reatores controle desnitrificante (CDT0 e CDT2). (a) e (b) filamentosas no reator DT0, (c) fungos no reator DT2, (d) filamentosas e bacilos no reator DT2.... 129 
Figura 5-40 Análise de cluster (Correlação de Pearson) do perfil de bandas do PCR/DGGE dos fragmentos RNAr 16S para o Domínio Bacteria para as amostras reatores desnitrificante no início (DT0), no meio (DT1) e final da operação (DT2), bem como para os reatores controle no início (CDT0), no meio (CDT1) e final da operação (CDT2)

Figura 5-41 Dendograma da análise de agrupamento das amostras dos reatores MT0, MT2, DT0 e DT2. Índice de similaridade calculado através do índice de dissimilaridade de Bray-Curtis e agrupamento UPGMA.

Figura 5-42 Árvore filogenética da biomassa dos reatores CD e CM construída com as quatro UTOs com maior abundancia relativa em cada amostra. A barra da escala refere-se a distância filogenética e Chlorella vulgaris foi escolhida como outgroup de 1.000 amostragens. $O$ número de acesso do GenBank está entre parênteses. 


\section{LISTA DE TABELAS}

Tabela 3-1 Fórmula molecular dos congêneres de PCB e porcentagem de congêneres de PCB no Arocloro.

Tabela 3-2 Resultados de remoção de PCB em reatores anaeróbios. …............................................................... 18

Tabela 3-3. Aplicação da técnica de SPME para avaliar amostras ambientais com PCB. ..........................22

Tabela 4-1. Solução A utilizada nos ensaio em batelada. ...........................................................................27

Tabela 4-2 Solução B utilizada nos ensaio em batelada. .................................................................................2 27

Tabela 4-3 Solução de resazurina utilizada nos ensaio em batelada .................................................................2 27

Tabela 4-4 Solução traço de metais e selenito utilizado nos ensaio em batelada..............................................28

Tabela 4-5 Solução de vitaminas utilizada nos ensaio em batelada .................................................................28

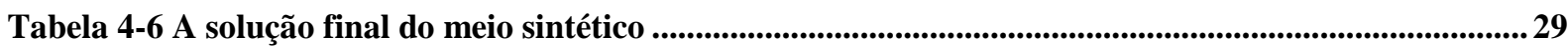

Tabela 4-7 Valores de DQO para as fontes de carbono utilizadas nos ensaios em batelada...........................29

Tabela 4-8 Condições avaliadas na escolha da melhor condição de extração e análise do PCB das amostras

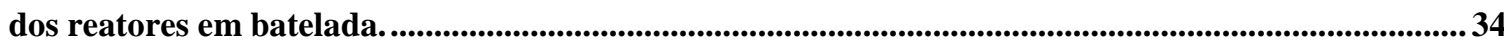

Tabela 4-9 Preparação da solução-estoque para utilização na curva analítica...............................................35

Tabela 4-10 Parâmetros estabelecidos para análise da concentração de PCB pela técnica de SPME......... 35

Tabela 4-11 Relação de pontos e concentrações adicionadas de PCB no método de Adição de Padrão...... 37

Tabela 4-12 A extração de DNA genômico das amostras seguindo o procedimento de Griffiths et al. (2000) modificado.

Tabela 4-13 Iniciadores para amplificação da região do RNAr 16S para o Domínio Bacteria....................39

Tabela 4-14 Programação do termociclador para amplificação do RNAr 16S para o Domínio Bacteria... 39

Tabela 4-15 Iniciadores para amplificação da região RNAr 16S para o Domínio Bacteria. ........................39

Tabela 4-16 Programação do termociclador para amplificação do RNAr 16S para o Domínio Archaea... 40

Tabela 4-17 Soluções para amplificação usando iniciadores 968FGC e 1401R e 1100FGC e 1400R.......... 40

Tabela 4-18 Composição dos reatores em batelada no primeiro ensaio de inibição metanogênica. .............46

Tabela 4-19 Composição dos reatores em batelada no segundo ensaio de inibição metanogênica................46

Tabela 4-20 Condição do ensaio em batelada para avaliar a remoção do PCB em condição fermentativametanogênica.

Tabela 4-21 Condição dos ensaios em batelada para avaliar a melhor Relação $\mathrm{C} / \mathrm{N}-\mathrm{NO}_{3}{ }^{-}$na presença de PCB.

Tabela 4-22 Condição dos ensaios em batelada para avaliar a taxa de inibição desnitrificante gerada pelo PCB.

Tabela 4-23. Reatores desnitrificante do ensaio em batelada para avaliar a remoção do PCB....................51

Tabela 5-1 Relação entre os picos obtidos no cromatograma, tempo de retenção e congêneres de PCBs...54

Tabela 5-2 Condições de extração para o teste com diferentes concentrações de NaCl para a técnica de SPME.

Tabela 5-3 Condição dos testes para a escolha do tipo de fibra na extração de PCB utilizando a técnica de SPME.

Tabela 5-4 Condição dos testes para a escolha do tempo de extração.

Tabela 5-5 Condição dos testes para a escolha da temperatura de dessorção de extração do PCB com a técnica de SPME.

Tabela 5-6 Condição dos testes para a escolha do volume amostral ideal na extração de PCB utilizando o SPME.

Tabela 5-7 Condição dos testes da utilização de padrão interno na extração do PCB com a técnica de SPME.

Tabela 5-8 As melhores condições definidas para a extração e análise do PCB por meio da técnica de SPME.

Tabela 5-9 Precisão Intra-dia do método de extração de PCB por SPME para cada analito diluído em meio sintético. 
Tabela 5-10 Porcentagem de recuperação relativa entre água ultrapurificada e a amostra fortificada com PCB.

Tabela 5-11 Comparação entre a produção máxima de metano nos reatores em batelada sem PCB e com concentrações baixas de PCB (0,5 mg.L $\mathrm{L}^{-1}$ e 0,7 mg.L $\left.{ }^{-1}\right)$ no presente estudo e literatura.........................77

Tabela 5-12 Ácidos orgânicos voláteis, inibição, produção máxima especifica de metano, DQO inicial e final e eficiência de remoção de DQO em cada reator no Ensaio de Inibição Metanogênica...............78

Tabela 5-13 Porcentagem e concentração de cada ácido orgânico volátil nos reatores RC (reator controle), R0,5 (reator com 0,5 mg.L $\mathrm{L}^{-1}$ de PCB), R1,5 (reator com 1,5 mg.L ${ }^{-1}$ de PCB), R3,0 (reator com 3,0 mg. $\mathrm{L}^{-1}$ de PCB), R4,5 (reator com 4,5 mg. $\mathrm{L}^{-1}$ de PCB) e R6,0 (reator com 6,0 mg. $\mathrm{L}^{-1}$ de PCB).........80

Tabela 5-14 Índice de diversidade de Shannon-Wienner (H') para as amostras provenientes dos reatores e do inóculo.

Tabela 5-15 Ácidos orgânicos voláteis, DQO e eficiência de remoção de DQO em cada reator no Ensaio de Remoção de PCB.

Tabela 5-16 Concentração e porcentagem de cada ácido orgânico volátil nos reatores MT0 (reator metanogênico no tempo inicial), MT1 (reator metanogênico em 81 dias de operação), MT2 (reator metanogênico em 101 dias de operação), CMT0 (reator controle metanogênico no tempo inicial), CMT1 (reator controle metanogênico em 81 dias de operação) e CMT2 (reator controle metanogênico em 101 dias de operação).

Tabela 5-17 Concentração dos seis congêneres de PCB (PCB 10, 28, 52, 153, 138 e 180) nos reatores controle (CM) ao longo do tempo de operação (T0 e T2) do ensaio em batelada.

Tabela 5-18 Concentração dos seis congêneres de PCB (PCB 10, 28, 52, 153, 138 e 180) nos reatores metanogênicos (M) ao longo do tempo de operação (T0, T1 e T2) do ensaio em batelada. ..................89

Tabela 5-19 Quantidade de sequencias e UTOs atribuídas a cada amostra (97 \% de similaridade)...........91

Tabela 5-20 Índices ecológicos de diversidade, dominância, equitabilidade e riqueza para o Domínio Bacteria e Archaea, nas amostras MT0 e MT2.

Tabela 5-21 Microrganismos do Domínio Archaea nos reatores metanogênicos no tempo inicial (T0) e final (T2) de operação (97\% de similaridade).

Tabela 5-22 Índice de Shannon-Wienner $\left(\mathrm{H}^{\prime}\right)$ para as amostras dos reatores metanogênicos do Ensaio de Remoção de PCB

Tabela 5-23 Relações $\mathrm{C} / \mathrm{N}$ em presença de compostos aromáticos.

Tabela 5-24 Parâmetros do Ensaio de Relação de Carbono e Nitrogênio em diferentes relações C-DQO/N-NO${ }^{-}$

Tabela 5-25 Concentração e porcentagem de ácidos orgânicos voláteis no meio sintético mais fonte de carbono, nos reatores no tempo inicial (T0) e final (TF) de operação para as diferentes relações de $\mathrm{C} / \mathrm{N}-\mathrm{NO}_{3}{ }^{-}$

Tabela 5-26 $\mathrm{NO}_{3}^{-}$residual, consumo de $\mathrm{NO}_{3}^{-}$e Eficiência de Desnitrificação (ED) nos reatores inoculados com diferentes concentrações de PCB.

Tabela 5-27 Ácidos orgânicos voláteis, DQO inicial e final e eficiência de remoção de DQO no Ensaio de Inibição Desnitrificante.

Tabela 5-28 Concentração e porcentagem de cada ácido orgânico volátil nos reatores RC (reator controle), R0,5 (reator com 0,5 mg. $\mathrm{L}^{-1}$ de PCB), R1,5 (reator com 1,5 mg. $\mathrm{L}^{-1}$ de PCB) e R3,0 (reator com 3,0 mg. $L^{-1}$ de PCB).

Tabela 5-29 Índice de diversidade de Shannon-Wienner (H') para as biomassas dos reatores e inóculo..114 Tabela 5-30 Ácidos orgânicos voláteis, DQO, eficiência de remoção de DQO e eficiência de Desnitrificação $\left(E_{D}\right)$ em cada reator no Ensaio de Remoção de PCB.

Tabela 5-31 Porcentagem e concentração de cada ácido orgânico volátil nos reatores DT0 (reator desnitrificante no tempo 0 dias), DT1 (reator desnitrificante no tempo 78 dias), DT2 (reator desnitrificante no tempo 99 dias), CDT0 (reator controle desnitrificante no tempo 0 dias), CDT1 (reator controle desnitrificante no tempo 78 dias) e CDT2 (reator controle desnitrificante no tempo 99 dias) 
Tabela 5-32 Concentração dos seis congêneres de PCB (PCB 10, 28, 52, 153, 138 e 180) nos reatores controle (CD) ao longo do tempo de operação (T0 e T2) do ensaio em batelada.

Tabela 5-33 Concentração dos seis congêneres de PCB (PCB 10, 28, 52, 153, 138 e 180) nos reatores desnitrificantes (D) ao longo do tempo de operação (T0, T1 e T2) do ensaio em batelada................. 119

Tabela 5-34 Quantidade de sequencias e UTOs atribuídas a cada amostra (97\% de similaridade)......... 120

Tabela 5-35 Índices ecológicos de diversidade, dominância, equitabilidade e riqueza para o Domínio Bacteria nas amostras DT0 e DT2.

Tabela 5-36 Índice de Shannon-Wienner $\left(\mathrm{H}^{\prime}\right)$ para as amostras dos reatores desnitrificante do Ensaio de Remoção de PCB.

Tabela 5-37 Quatro grupos mais abundantes em cada amostra MT2 e DT2, relação de UTO representativa, filiação a partir do $R D P$ classifier e abundância relativa em cada amostra 132

Tabela 5-38 Comparação entre a concentração biossorvida dos seis congêneres de PCB (PCB 10, 28, 52, 153, 138 e 180) nos reatores controle desnitrificante (CD) e metanogênico (CM). 135 


\section{SUMÁRIO}

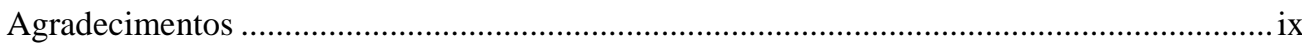

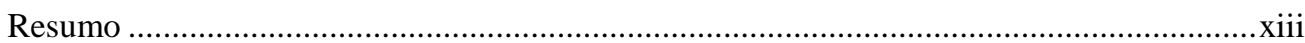

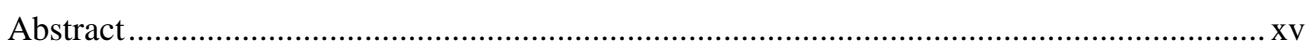

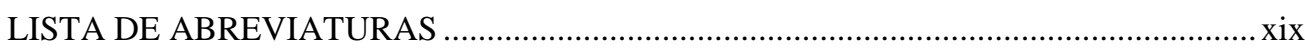

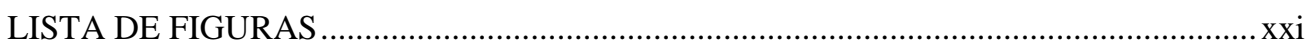

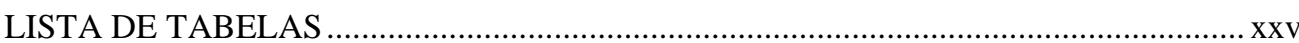

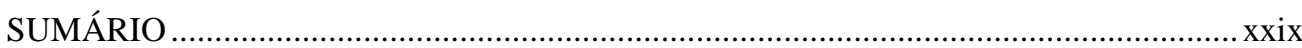

1 INTRODUÇÃ

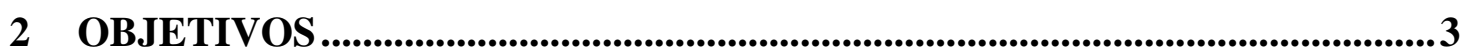

Hipótese 1: A técnica de SPME é eficaz para determinar a concentração de PCB de amostras de

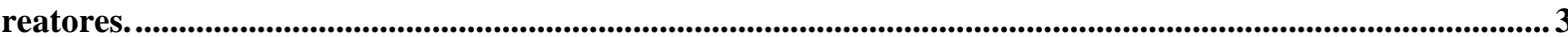

Hipótese 2: A condição fermentativa-metanogênica abriga comunidade resistente a presença de

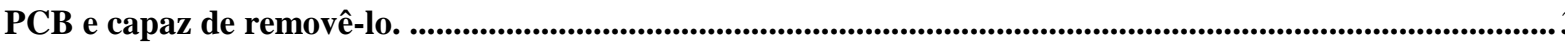

Sub-Hipótese 2A: A presença do PCB inibe a comunidade fermentativa-metanogênica .................. 3

Sub-Hipótese 2B: A comunidade fermentativa-metanogênica é capaz de remover o PCB, e a presença do PCB altera a comunidade microbiana.

Hipótese 3: A condição desnitrificante abriga comunidade resistente a presença de PCB e capaz de removê-lo.

Sub-Hipótese 3A: A relação $\mathrm{C} / \mathrm{N}-\mathrm{NO}_{3}^{-}$para a comunidade desnitrificante é especifica na presença do PCB.

Sub-Hipótese 3B: A concentração de PCB inibe a comunidade desnitrificante. 4

Sub-Hipótese 3C: Sob condição desnitrificante o PCB é removido e a presença do tóxico afeta a composição da comunidade microbiana.

Hipótese 4: A remoção de PCB e a composição microbiana são distintas sob condição fermentativa-metanogênica e desnitrificante.

3 REVISÃO BIBLIOGRÁFICA ...................................................................

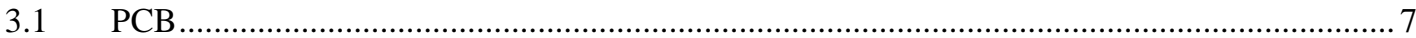

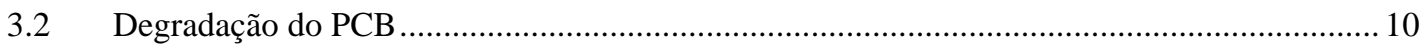

3.2.1 Desalogenação do PCB ......................................................................................... 12

3.3 Análise de toxicidade anaeróbia ......................................................................................... 14

3.4 Metabolismo Metanogênico......................................................................................... 15

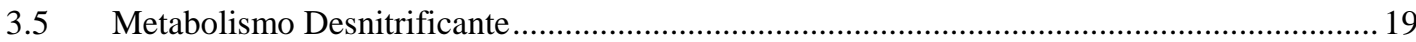


3.6 Extração e análise cromatográfica do PCB .................................................................20

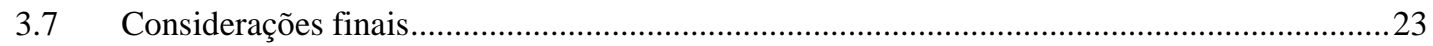

4 MATERIAL E MÉTODOS ................................................................................ 25

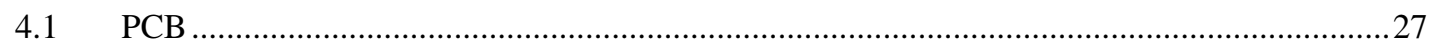

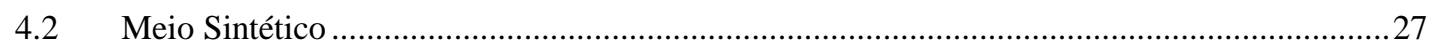

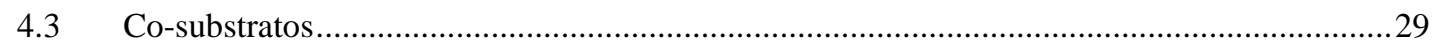

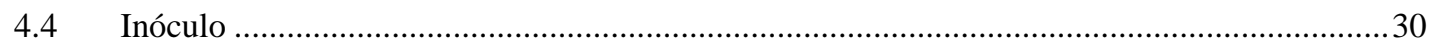

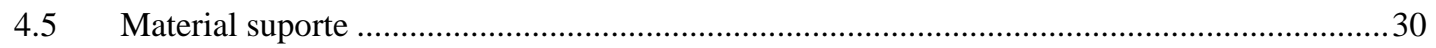

4.6 Procedimentos Analíticos para acompanhamento dos experimentos laboratoriais .................31

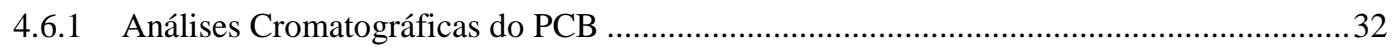

I. Microextração em fase sólida............................................................................................... 32

II. Elaboração das curvas de calibração e validação ............................................................ 35

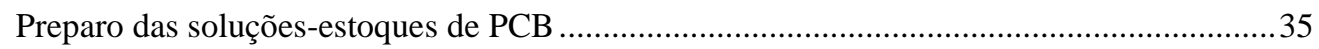

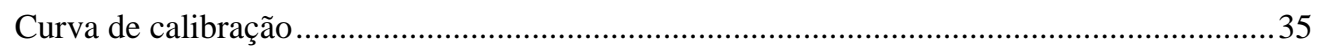

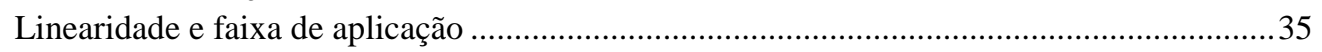

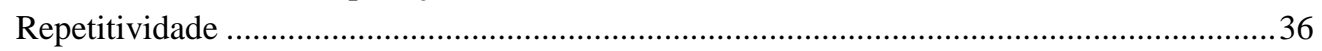

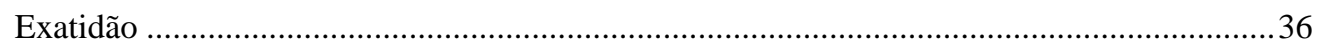

III. Determinação da concentração de PCB nos reatores em batelada .....................................37

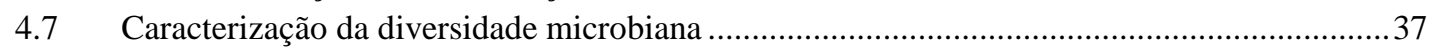

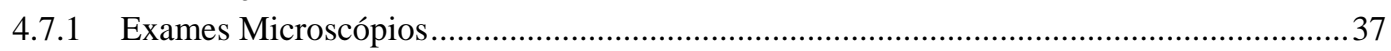

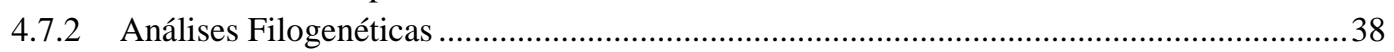

I) Estocagem de amostra e extração de DNA ......................................................................... 38

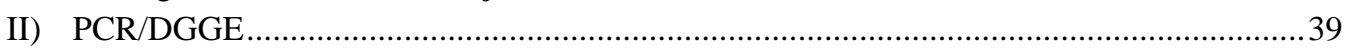

III) Sequenciamento Massivo ......................................................................................... 40

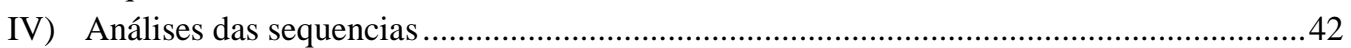

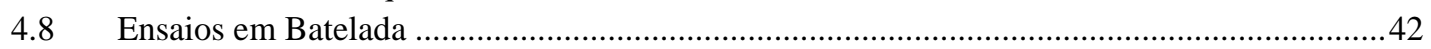

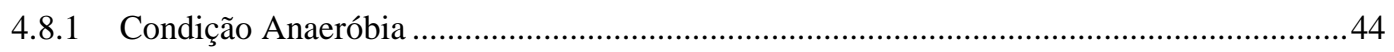

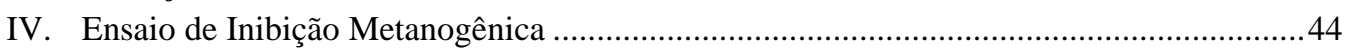

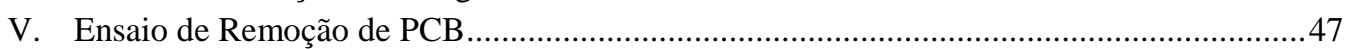

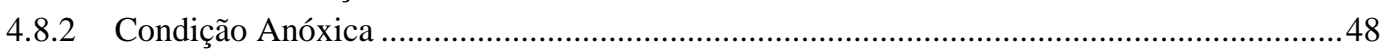

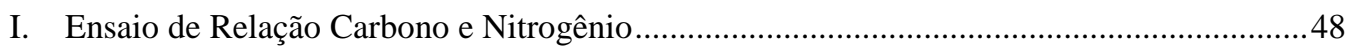

II. Ensaio de Inibição Desnitrificante .............................................................................49

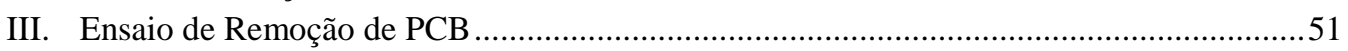

5 RESULTADOS E DISCUSSÃO...................................................................53

5.1 Desenvolvimento e validação de método para determinação de PCB via SPME ....................53

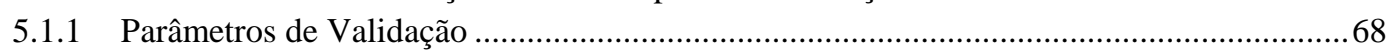

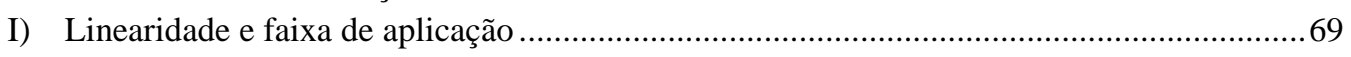

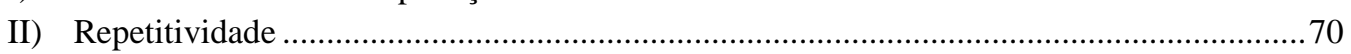

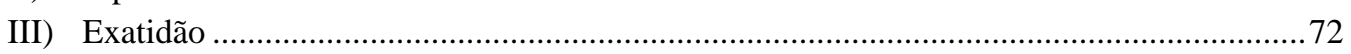

5.1.2 Determinação da concentração de PCB nos reatores em batelada....................................72

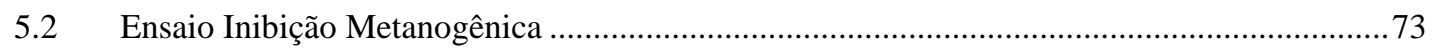

5.3 Ensaio de Remoção de PCB sob condição fermentativa-metanogênica .................................8 84

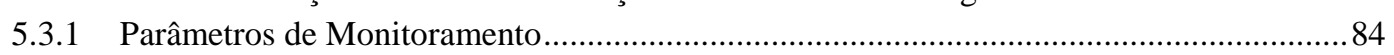

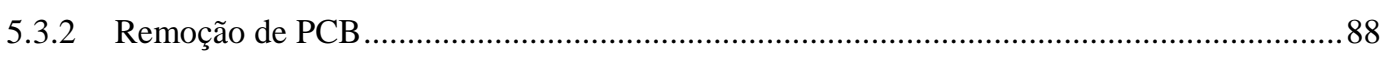

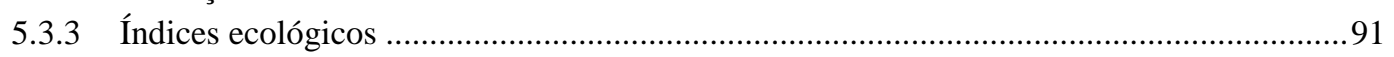

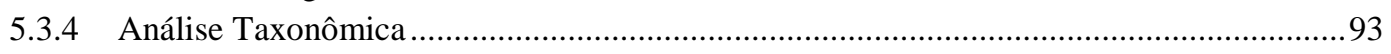

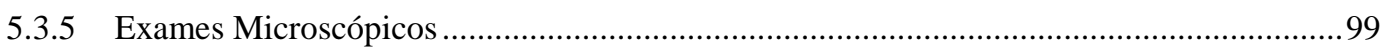


5.3.6 Caracterização da comunidade microbiana ................................................................... 101

5.4 Ensaio de Relação Carbono e Nitrogênio ............................................................................ 103

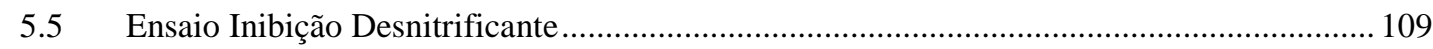

5.6 Ensaio de Remoção PCB sob condição desnitrificante........................................................ 114

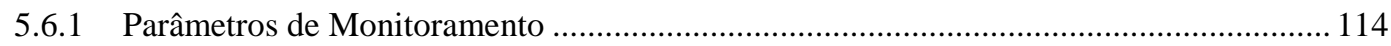

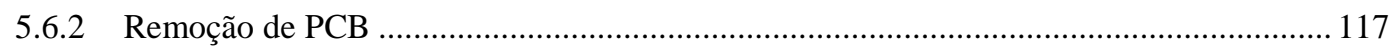

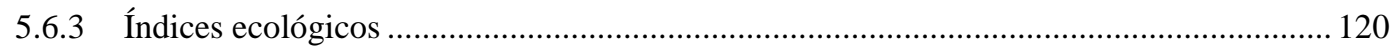

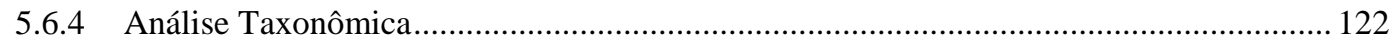

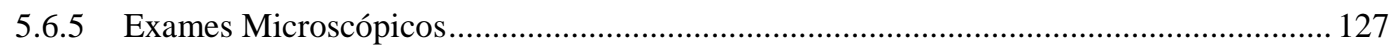

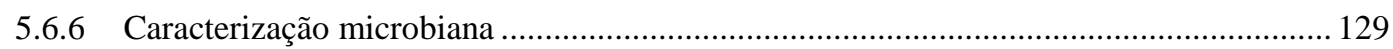

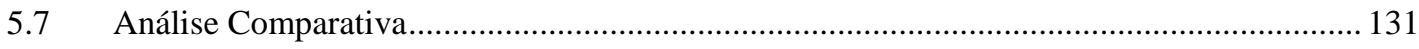

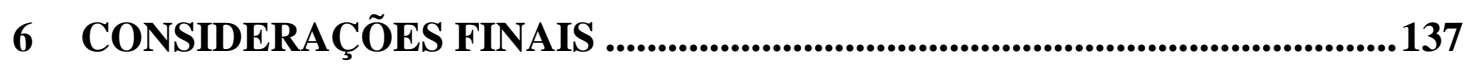

Hipótese 1: O SPME é uma metodologia eficaz da avaliação de PCB de amostras de reatores... 137

Hipótese 2: A condição fermentativa-metanogênica abriga comunidade resistente a presença de

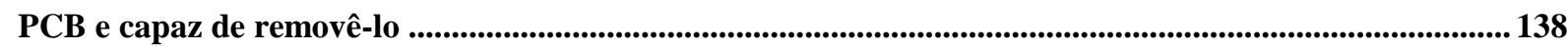

Sub-Hipótese 2A: A presença do PCB inibe a comunidade fermentativa-metanogênica ............... 138

Sub-Hipótese 2B: A comunidade fermentativa-metanogênica é capaz de remover o PCB, e a presença do PCB altera a comunidade microbiana.

Hipótese 3: A condição desnitrificante abriga comunidade resistente a presença de PCB e capaz de removê-lo.

Sub-Hipótese 3A: A relação $\mathrm{C} / \mathrm{N}-\mathrm{NO}_{3}{ }^{-}$para a comunidade desnitrificante é especifica na presença do PCB.

Sub-Hipótese 3B: A concentração de PCB inibe a comunidade desnitrificante. 139

Sub-Hipótese 3C: Sob condição desnitrificante o PCB é removido e a presença do tóxico afeta a composição da comunidade microbiana.

Hipótese 4: A remoção de PCB e a composição microbiana foi distinta em cada condição. 140

7 CONCLUSÕES

8 REFERÊNCIAS BIBLIOGRÁFICAS 143

9 APÊNDICES 157 


\section{1 minsuasio}

Os PCBs são moléculas orgânicas estáveis, com baixa flamabilidade, e boa propriedade isolante. Estas características levaram a sua utilização em larga escala em transformadores e capacitores como fluidos dielétricos e isolantes térmicos (ABRAMOWICZ, 1990; TIEDJE et al., 1993; PENTEADO; VAZ, 2001; BORJA et al., 2005). Na prática, em instalações industriais e comerciais são encontrados compostos com misturas de 60 a 90 congêneres deste composto (FIELD; SIERRA-ALVAREZ, 2008), como exemplo o arocloro 1254, no qual os primeiros dois dígitos informam o número de átomos de carbono (doze, no caso do PCB) e os últimos dois dígitos indicam a porcentagem de cloro na molécula (54\% de cloro).

A elevada concentração de cloro das bifenilas policloradas aumenta a toxicidade do composto dificultando sua degradação. Ademais, característica como bioconcentração e bioacumulação são propriedades que devem ser consideradas quando avalia-se a contaminação ambiental por tais compostos (BOPP, 1986). A contaminação de PCB no Brasil foi confirmada em estudo realizado na Bahia de Santos-São Vicente, em São Paulo (CETESB, 2001). Neste estudo foi identificado presença de concentrações acima do permitido em organismos aquáticos, como animais filtradores, revelando a necessidade de um plano de ação para o controle e remoção de PCB.

A utilização de microrganismos na remoção de compostos como o PCB é uma possibilidade biotecnológica que se tornou o foco de extensivas pesquisas nas últimas décadas. Consequentemente, o conhecimento de mecanismos de dissipação destes compostos, em ambientes naturais, foi intensamente aprofundado.

Diversas são as pesquisas que visam desenvolver possibilidades tecnológicas para degradar PCB no ambiente. Para o melhor entendimento e aperfeiçoamento dos processos biológicos, ainda deverão 
ser realizadas pesquisas acerca dos diversos fatores que interferem em sua degradação, tais como metodologia de análise, o processo empregado, presença de determinados microrganismos, produtos e possível inibição dos microrganismos.

Técnicas tradicionais de extração de PCB, como líquido/liquido, apresentam alto gasto com solventes e elevado tempo de extração despendido na análise. No Laboratório de Processos Biológicos - LPB (USP - São Carlos) realizou-se série de estudos visando a análise de PCB em amostras ambientais por meio de diferentes técnica de extração, como líquido-líquido, SPE (extração em fase sólida) e SPME (microextração em fase sólida) (ADORNO, 2013). Entretanto a utilização da técnica de SPME foi avaliada apenas em amostras de sedimento contaminado com ascarel (ADORNO, 2013). Assim, a aplicação da técnica de SPME para análise de seis congeneres de PCB em reatores em batelada foi avaliada neste estudo.

Em trabalhos anteriores a remoção de cloro de PCB por bactérias anaeróbias não foram evidenciadas em menos de quatro meses com consórcio não-adaptado (CHANG; CHOU; YUAN, 1999). Entretanto, Gomes et al. (2014) evidenciaram para consócio fermentativo-metanogênico não-adaptado capacidade de degradação de PCB (PCB 10, 28, 52, 138, 153 e 180) com taxa de remoção de 0,7 a 0,2 mg.mL $\mathrm{m}^{-1}$ para concentração inicial de $0,7 \mathrm{mg} . \mathrm{L}^{-1}$ em reatores em batelada por 60 dias. Desse modo, a aplicação de consórcios fermentivo-metanogênico em reatores anaeróbios e a identificação das concentrações inibitórias de PCB podem elucidar lacunas referentes a remoção desse composto.

Além dos desafios encontrados em relação a biodegradação de PCB em reatores, pouco se tem avançado na aplicação de diferentes receptores de elétrons. Ressalta-se que a escassez de receptores de elétrons em sistemas naturais na ausência de oxigênio representa uma barreira na remoção de compostos tóxicos (REDDY et al., 2002), como o PCB. Consequentemente, qualquer microrganismo que possa utilizar diferentes receptores de elétrons, como o nitrato, poderia ter uma vantagem em relação aos outros microrganismos capazes de utilizar PCB em reatores biológicos.

O nitrato como receptor final de elétrons foi utilizado eficientemente em diversos reatores no tratamento de outros compostos aromáticos e clorados (SANFORD; TIEDJE, 1997; GUSMÃO et al., 2007; MARTÍNEZ-GUTIÉRREZ et al., 2012). Entretanto, existem poucos relatos na literatura que utilizaram este receptor final de elétrons na degradação do PCB. Deve-se salientar que não há nenhum relato na literatura relacionado à toxicidade anóxica do PCB. Assim, para responder as lacunas acerca da comunidade desnitrificante na biodegradação de PCB sob condição anóxica, neste estudo avaliou-se a relação $\mathrm{C} / \mathrm{N}^{-} \mathrm{NO}_{3}{ }^{-}$e a concentração inibitória capazes de interferir no metabolismo desta comunidade.

Mediante o exposto, objetivou-se no presente trabalho avaliar a remoção do PCB com consórcio não-adaptado em reatores em batelada comparando-se a comunidade anaeróbia (fermentativametanogênica) e anóxica (desnitrificante), investigando o comportamento destas comunidade na presença de diferentes concentrações de PCB e comparando a composição da comunidade microbiana, por meio de sequenciamento massivo da biomassa sob condição anaeróbia e anóxica. 


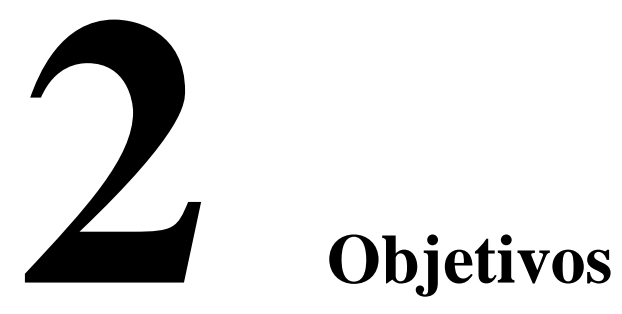

Nesta tese foram apresentadas hipóteses e sub-hipóteses distintas associadas aos seus respectivos objetivos:

\section{Hipótese 1: A técnica de SPME é eficaz para determinar a concentração de PCB de amostras de reatores.}

A aplicação de um método de análise do PCB que envolve a preparação da amostra sem a necessidade de adição de solvente integrando a amostragem, isolamento e a concentração em única etapa é uma vantagem significativa nas análises de amostras ambientais.

* Objetivo: Avaliar metodologia de extração de PCB pelo método de SPME para a identificação e quantificação de seis congêneres de PCB.

\section{Hipótese 2: A condição fermentativa-metanogênica abriga comunidade resistente a presença de PCB e capaz de removê-lo.}

A fermentação-metanogênese é uma das principais vias metabólicas nos sistemas anaeróbios e sob tal condição ocorre a desalogenação redutiva do PCB.

\section{Sub-Hipótese 2A: A presença do PCB inibe a comunidade fermentativa- metanogênica}

Técnicas como a análise de toxicidade anaeróbia são indicadores da versatilidade e resistência da comunidade metanogênica em sistemas de remoção de compostos tóxicos e, por meio delas pode-se avaliar o efeito adverso de um composto sobre a taxa de produção de biogás. 
* Objetivo: Avaliar a concentração inibidora de PCB para a comunidade fermentativa-metanogênica em reatores em batelada, inoculados com lodo anaeróbio não-adaptado.

\section{Sub-Hipótese 2B: A comunidade fermentativa-metanogênica é capaz de remover o PCB, e a presença do PCB altera a comunidade microbiana.}

Apesar do processo de degradação anaeróbia de PCB ocorrer naturalmente em sedimentos marinho e de água doce, tem-se baixos rendimentos em relação às condições de laboratório. Desse modo, a aplicação de consórcios anaeróbios provenientes de lodos podem aumentar a taxa de degradação do PCB e metodologias mais eficientes na identificação dessa comunidade podem elucidar lacunas referentes a remoção desse composto.

* Objetivo: Avaliar a remoção efetiva de PCB nos ensaios em batelada inoculados com lodo anaeróbio não-adaptado.

* Objetivo: Analisar a composição e diversidade microbiana nos reatores anaeróbios.

\section{Hipótese 3: A condição desnitrificante abriga comunidade resistente a presença de PCB e capaz de removê-lo.}

Baseado nas equações de termodinâmica, a oxidação completa de compostos organoclorados aliado a redução de nitrato pode ser um processo energeticamente favorável.

\section{Sub-Hipótese 3A: A relação $\mathrm{C} / \mathrm{N}-\mathrm{NO}_{3}{ }^{-}$para a comunidade desnitrificante é especifica na presença do $\mathrm{PCB}$.}

Diferentes fontes de carbono e a relação carbono e nitrogênio no sistema $(\mathrm{C} / \mathrm{N})$ produz diferentes taxas de desnitrificação. A relação ideal $\mathrm{C} / \mathrm{N}$ no sistema desnitrificante sob condições especificas, como a presença de tóxico, deve ser determinada experimentalmente.

* Objetivo: Definir a relação ideal $\mathrm{C} / \mathrm{N}-\mathrm{NO}_{3}{ }^{-}$para a comunidade desnitrificante na presença de PCB em reatores em batelada inoculados com lodos ativados não-adaptado.

\section{Sub-Hipótese 3B: A concentração de PCB inibe a comunidade desnitrificante.}

A redução completa do nitrato a gás nitrogênio é sensível a presença de inibidores, como o PCB, e pode ocasionar o acúmulo de intermediários e a diminuição do consumo de nitrato. 
* Objetivo: Avaliar o impacto que diferentes concentrações de PCB podem ocasionar no metabolismo desnitrificante em reatores em batelada inoculados com lodos ativados não-adaptado.

\section{Sub-Hipótese 3C: Sob condição desnitrificante o PCB é removido e a presença do tóxico afeta a composição da comunidade microbiana.}

A utilização de reator anóxico pode ser uma metodologia inovadora na degradação do PCB, e estudos mais aprofundados acerca do papel da microbiota anóxica nesses reatores faz-se necessário.

* Objetivo: Avaliar a remoção efetiva de PCB nos ensaios em batelada inoculados com lodos ativados não-adaptado.

* Objetivo: Analisar a composição e diversidade microbiana nos reatores anóxicos.

\section{Hipótese 4: A remoção de PCB e a composição microbiana são distintas sob condição fermentativa-metanogênica e desnitrificante.}

Poucos estudos tiveram como objetivo determinar a remoção de PCB em diferentes condições metabólicas e comparar a diversidade microbiana dos consórcios microbianos após a exposição ao PCB utilizando sequenciamento massivo de alto rendimento

* Objetivo: Comparar a remoção de PCB sob condição fermentativametanogênica e desnitrificante.

* Objetivo: Comparar a diversidade de microrganismos nos reatores anaeróbios e anóxicos no final da operação. 


\section{Revisão Bibliográfica}

\subsection{PCB}

Os PCBs são moléculas orgânicas estáveis, com baixa flamabilidade, alta temperatura de vaporização, baixo grau de reatividade, alta resistência elétrica e boa propriedade isolante. Estas características levaram a sua utilização em larga escala em transformadores e capacitores como fluidos dielétricos e isolantes térmicos instalados em área onde os riscos de incêndio e explosão deveriam ser minimizados (como em sub-estações elétricas localizadas no interior de prédios, trens e navios ou em locais com trânsito frequente de pessoas) (ABRAMOWICZ, 1990; TIEDJE et al., 1993; PENTEADO; VAZ, 2001;BORJA et al., 2005).

A síntese do PCB tem sua origem no processo de refino do petróleo. Deste processo origina-se o benzeno, que após a extração e purificação, é utilizado na produção da bifenila (BAIRD; CANN, 2012). Bifenilas policloradas são produzidas pela inserção direta de cloro no anel com a presença de catalisador como o cloreto férrico (HUTZINGER; SAFE; ZITKO, 1974). A molécula de PCB é formada por dois anéis de seis carbonos, contendo de 1 a 10 moléculas de cloro (Figura 3-1). São produzidas 209 possíveis diferentes combinações de acordo com a posição e quantidade de átomos de cloro inserido nos anéis. Estes isômeros e homólogos são comumente denominados de congêneres (ABRAMOWICZ, 1990).

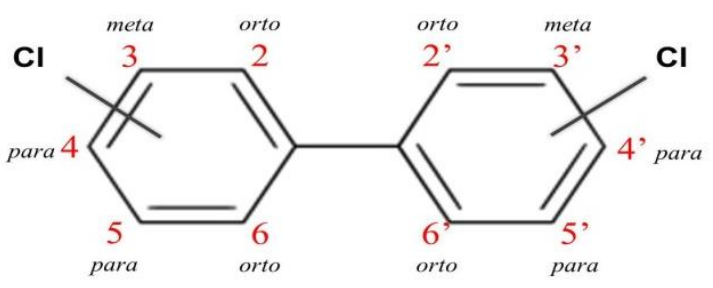

(a)

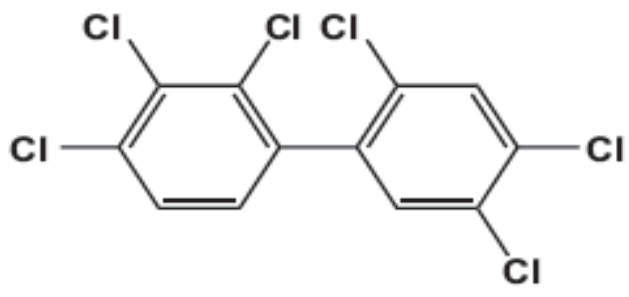

(b)

Figura 3-1. (a) Estruturas da bifenila; (b) PCB 138 (2,2',3,4,4',5'-hexaclorobifenila) 
Tendo em vista que as misturas de bifenilas policloradas obtidas comercialmente possuíam alta viscosidade, houve a necessidade de misturar o PCB com solventes benzoclorados, com o objetivo de conferir à mistura uma viscosidade conveniente para que atuasse como agente dissipador de calor dentro dos equipamentos elétricos (ANTONELLO et al., 2007).

Essa mistura de PCB e solvente organoclorado ficou conhecida como ascarel, no Brasil, ou Aroclor, nos EUA (PENTEADO; VAZ, 2001). O ascarel tipo A (composto por 60\% de arocloro $1260 \mathrm{e}$ $40 \%$ triclorobenzeno) e ascarel tipo B (composto por $70 \%$ de arocloro 1254 e $30 \%$ triclorobenzeno) são alguns exemplos de como o PCB foi comercializado (ANTONELLO et al., 2007) (Tabela 3.1). 
Tabela 3-1 Fórmula molecular dos congêneres de PCB e porcentagem de congêneres de PCB no Arocloro.

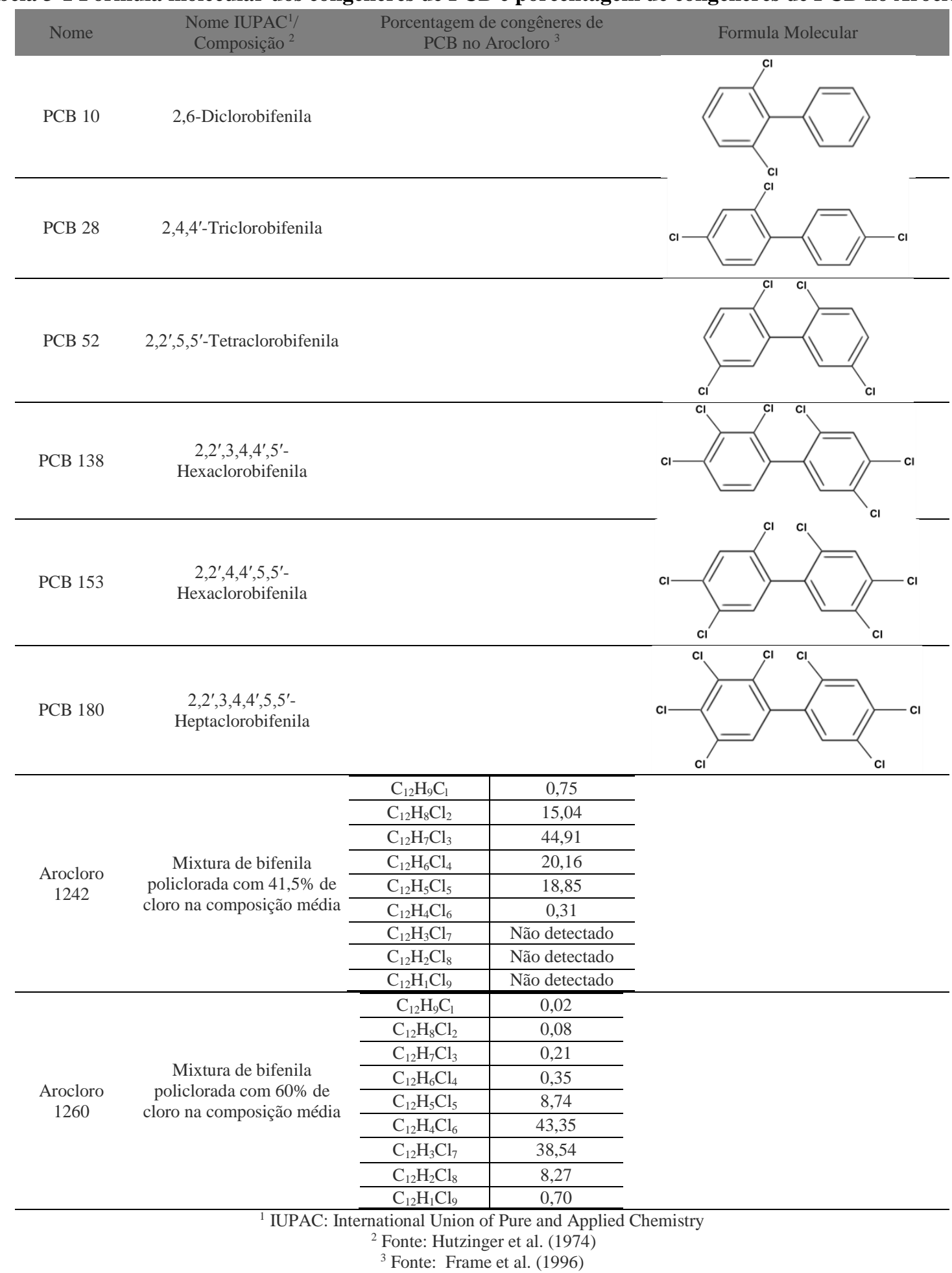

A presença do PCB no ambiente vem sendo relatada desde antes da proibição de sua manufatura em 1979 (US EPA - United States Environmetal Protection Agency) principalmente por meio de resíduos mal conservados, destinação imprópria ou ilegal de resíduos de PCB e eliminação de equipamentos que contenham óleo de PCB em aterros municipais ou lixões não projetados para lidar com resíduos tóxicos. A contaminação do ambiente persiste principalmente pela capacidade do PCB de 
bioconcentração no ambiente (aumento imediato da densidade de um poluente assim que passa do meio aquoso para o organismo aquático) e bioacumulação na cadeia trófica (acumulação do poluente ao longo da cadeia trófica a partir da alimentação) (LEISTER; BAKER, 1994; KO; BAKER, 2004). Estas características reunidas a presença de cloro em sua molécula, aumenta a toxicidade do PCB e dificultam sua biodegradação (SAFE, 1994; KO; BAKER, 2004).

A produção acumulada mundial foi estimada em 1.300.000 toneladas, entre 1930 e 1993 (BREIVIK et al., 2002). Dentre os quais estima-se que $40 \%$ estejam no ambiente e parte ainda encontrase em uso ou armazenado (PENTEADO; VAZ, 2001; BREIVIK et al., 2002).

Em função da ocorrência da deposição e acumulação do PCB no ambiente existe proeminente preocupação dos órgãos de controle em relação aos possíveis riscos ambientais e para a saúde humana. Os efeitos do PCB na saúde humana foram primeiramente documentados em 1968, em Yusho, Japão. Neste ano, milhares de indivíduos foram contaminados ao consumirem óleo de arroz contaminado com PCB. Os sintomas relatados foram relacionados com dermatites, hiperpigmentação da pele, danos no fígado e tireóide e mais seriamente no sistema nervoso periférico (ATSDR, 2000). Recentemente, aumentos significativos na concentração de PCB em leite materno foi evidenciado em países com baixa industrialização (ASANTE et al., 2011), indicando potencial risco a saúde humana (GIOIA et al., 2014).

A contaminação de PCB no Brasil foi confirmada em estudo realizado na Bahia de Santos-São Vicente, em São Paulo (CETESB, 2001). Neste estudo foi identificado presença de concentrações elevadas de PCB em organismos aquáticos, de até $45,05 \mu \mathrm{g} \cdot \mathrm{kg}^{-1}$ em peixe. Estes valores estão acima do permitido pela US EPA, que consideram o limite de $14 \mu \mathrm{g} \cdot \mathrm{kg}^{-1} \mathrm{em}$ organismos aquáticos.

Em São Paulo, a Lei Estadual 12.288 de 22 de fevereiro de 2006 discorre sobre a eliminação controlada dos PCBs e de acordo com os critérios estabelecidos nesta lei, os grupos que utilizam ou tenham equipamentos contendo PCBs, bem como óleos ou outros materiais contaminados, ficam obrigados a providenciar a sua eliminação progressiva até 2020 .

Na sua quarta reunião, em maio de 2009, a Convenção de Estocolmo promoveu o intercâmbio de informações sobre o manejo ambientalmente favorável do PCB. O PCB Elimination Network (PEN), ou Rede de Eliminação do PCB, é um acordo voluntário para a troca de informações e visa uma melhor coordenação e cooperação na eliminação do PCB. De acordo com esta resolução é obrigatório a substituição de equipamentos contendo PCB até 2025 e eliminação por completo desses resíduos tóxicos até 2028 (UNEP, 2011; WARMUTH; OHNO, 2013).

Devido a estas premissas, o uso de técnicas de degradação que não resultem na formação de compostos secundários mais tóxicos como possibilidade de eliminação de PCB tem atraído muita atenção.

\subsection{Degradação do PCB}

Compostos organoclorados alifáticos e aromáticos podem ser utilizados como fonte de carbono e energia no metabolismo microbiano ou ainda podem servir como receptor final de elétrons (CAINES, 2003; KOENIG; LEE; MANEFIELD, 2014). A forma como estes compostos são utilizados interferem diretamente na sua biodegradação. Estes compostos clorados podem ser degradados por meio de mineralização ou participação em reações co-metabólicas (HARDMAN; MCELDOWNEY; WAITE, 1993; DOBBINS, 1995; KOENIG; LEE; MANEFIELD, 2014). 
No processo de mineralização, os microrganismos utilizam o poluente como fonte de carbono e energia, resultando na redução do composto em seus elementos constituintes. No processo de participação em reações co-metabólicas, o microrganismo necessita de um co-substrato orgânico como fonte de carbono e/ou energia. Neste caso, a redução do poluente com o co-substrato é concomitante (CAINES, 2003).

Para compostos biodegradáveis, sempre ocorre a mineralização, todavia para os outros compostos são produzidas reações incompletas e, consequentemente, há formação de metabólitos intermediários potencialmente tóxicos. Nessa última condição, um segundo consórcio microbiano é necessário para a utilização dos metabólitos produzidos (BORJA et al., 2005).

A partir dos anos 70 foram publicados os primeiros trabalhos sobre microrganismos capazes de degradar PCB (AHMED; FOCHT, 1973; OHMORI et al., 1973; FURUKAWA; MATSUMURA, 1976; MASAI et al., 1995). Entretanto, somente em pesquisas posteriores foram elucidadas etapas metabólicas desta degradação (BOPP, 1986).

A mineralização biológica do PCB pode ser dividida em duas categorias distintas: aquelas que ocorrem sob condições anaeróbias e aquelas que ocorrem aerobiamente (BOYLE et al., 1992). Os microrganismos aeróbios atacam o anel bifenil por meio de reações oxidativas (Figura 3-2) e essa degradação comumente se inicia pela adição de oxigênio por meio da enzima 2,3-dioxigenase (BphA), com posterior desidrogenação pela enzima dihidrodiol desidrogenase $(\mathrm{BphB})$. A segunda enzima dioxigenase, 2,3-dihidroxibifenil dioxigenase $(\mathrm{BphC})$ é responsável pela quebra do anel (ABRAMOWICZ, 1990).

Sob tais condições, o produto é então hidrolisado a ácido benzóico e 2-hidroxipenta-2,4dienoato pela enzima hidrolase $(\mathrm{BphD})$. Estas enzimas são responsáveis pela degradação aeróbia do bifenil e do PCB com baixo teor de cloro e são codificadas pelos agrupamentos de genes gph (FURUKAWA; MIYAZAKI, 1986; ERICKSON; MONDELLO, 1992; TAIRA et al., 1992; FUKUDA et al., 1994; HOFER; BACKHAUS; TIMMIS, 1994; MASAI et al., 1995; FURUKAWA; SUENAGA; GOTO, 2004). 


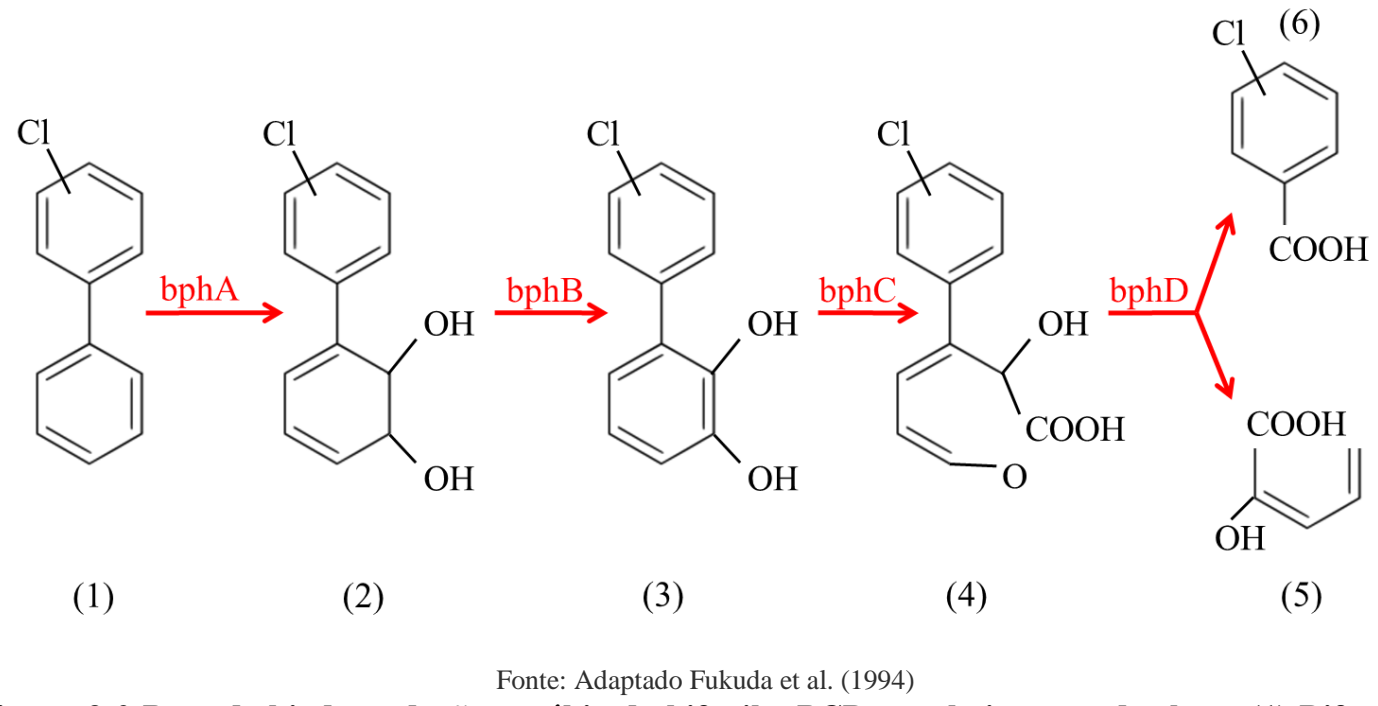

Figura 3-2 Rota de biodegradação aeróbia do bifenil e PCB com baixo teor de cloro. (1) Bifenil/ PCB; (2) cis 2,3-dihidroxibifenil; (3) 2,3-dihidroxibifenil; (4) ácido 2-hidroxi-6-oxo-6-fenilexa-2,4- dienóico; (5) ácido 2-hidroxipent-2,4- dienóico; (6) ácido benzoico/ clorobenzóico. bphA: bifenil 2,3-dioxigease; bphB: cis-2,3dihidroxibifenil desidrogenase; bphC: 2,3-dihidroxibifenil 1,2-dioxigenase; bphD: 2-hidroxi-6-oxo-6fenilexa-2,4-dienoato hidrolase.

Embora, a reação de degradação de PCB seja realizada preferencialmente pela via degradativa bphA, é possível que o PCB seja metabolizado por outras vias e a degradação do $\mathrm{PCB}$ até $\mathrm{CO}_{2}$ pode ocorrer anaerobiamente (CHEN et al., 1988; ABRAMOWICZ, 1990). Em função das características dos microrganismos tem-se atividade singular, a qual é dependente dos congêneres de PCB que irão metabolizar. Algumas espécies possuem espectro de degradação bem restrito, utilizando poucos congêneres, enquanto outras, como Burkolderia sp. LB400 e Rhodococcus globerulus P6, são capazes de degradar ampla gama de congêneres (BOPP, 1986; ASTURIAS; TIMMIS, 1993; KUMAR, 2004).

Poucas cepas isoladas que degradam PCB aerobiamente são capazes de mineralizar-lo (TIEDJE et al., 1993). A maioria degrada o anel menos clorado e libera o segundo anel como clorobenzoato, limitadas pelo bloqueio do sítio do ataque enzimático pelo átomo de cloro (TIEDJE et al., 1993). Assim, para a mineralização do PCB necessita-se de bactérias que realizam o rompimento do anel bifenil, bem como de outras com capacidade de realizar a remoção de cloro de PCB.

A remoção de cloro ou desalogenação (processo de participação em reações co-metabólicas) é uma etapa imprescindível para que aconteça a mineralização do PCB. Os padrões de desalogenação de PCB são de difícil generalização devido à diversidade microbiológica e a variedade de congêneres de PCB com diferentes concentrações de cloro (ZHANG; BENNETT, 2005).

\subsubsection{Desalogenação do PCB}

O metabolismo microbiano baseia-se em reações de redução e oxidação e, a seleção de microrganismos capazes de oxidar compostos organoclorados como doador de elétrons e/ou reduzir compostos organoclorados como receptor final de elétrons pode ser uma vantagem competitiva (BOSSERT; HÄGGBLOM; YOUNG, 2003). A biodegradação de PCB, por exemplo, inclui algumas reações com a função de retornar o cloro orgânico para o seu estado mineral (processo denominado desalogenação). A desalogenação pode ocorrer sob condições aeróbias, chamadas desalogenação 
oxidativa (ou oxigenolítica) e sob condições anóxicas e anaeróbias, denominadas de desalogenação hidrolítica e desalogenação redutiva, respectivamente (Figura 3-3).

$\mathrm{Na}$ desalogenação oxigenolítica ocorre a substituição do átomo de cloro pelo oxigênio em condições aeróbias (BOSSERT; HÄGGBLOM; YOUNG, 2003). Esta via é dependente da posição do cloro e a substituição só ocorre quando dois átomos de oxigênio são incorporados nos carbonos não ligados a átomo de cloro (ROBINSON; LENN, 1994).

Já na desalogenação hidrolítica, a liberação do cloro ocorre por meio da incorporação do grupo hidroxila proveniente da água (BOSSERT; HÄGGBLOM; YOUNG, 2003). Esta reação ocorre em meio aquoso, pode ocorrer em condições anóxicas (desnitrificante) (ROBINSON; LENN, 1994), sendo os intermediários deste processo derivados dos compostos oxigenados orgânicos (IVANOV, 2010).

Por fim, na desalogenação redutiva os microrganismos utilizam o processo para obter energia para seu metabolismo e crescimento (VOS et al., 2011). Esta desalogenação ocorre por meio da substituição do átomo de cloro por hidrogênio produzido durante a fermentação (IVANOV, 2010).

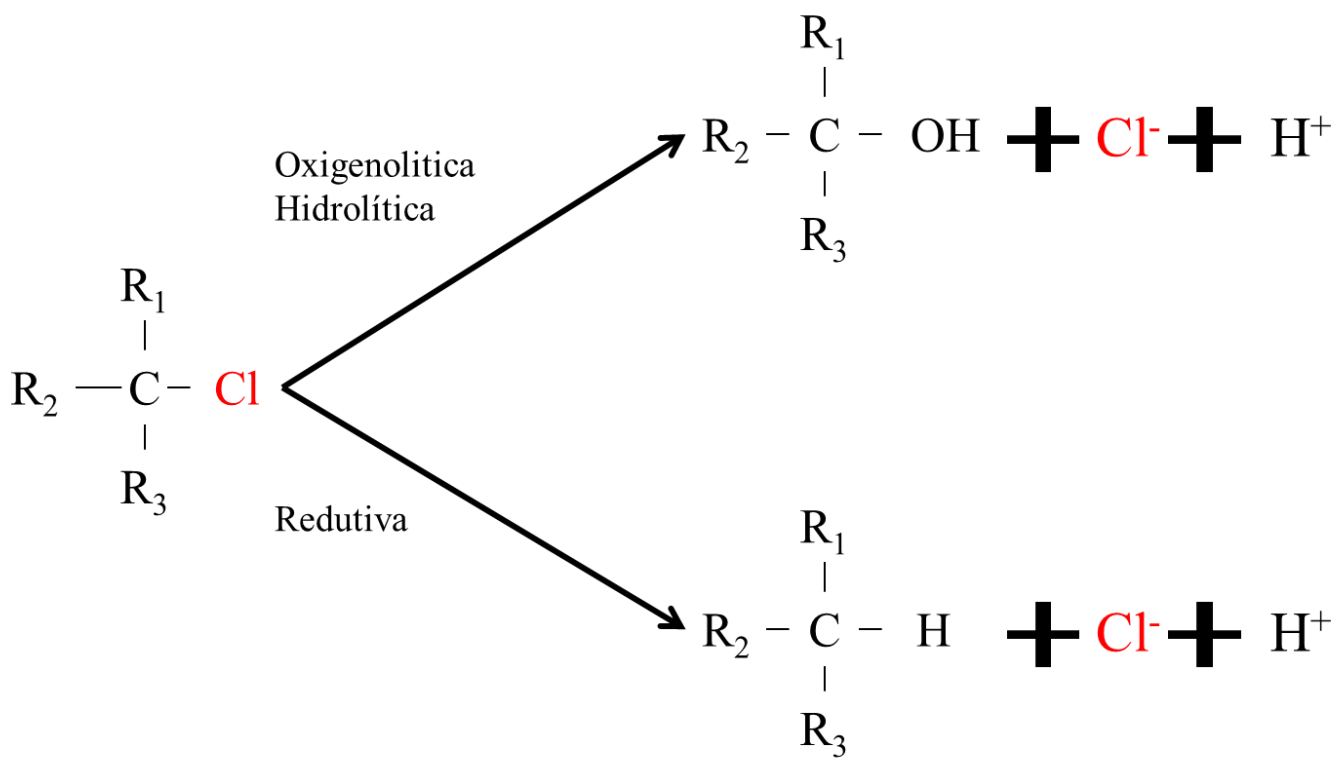

Fonte: Adaptado Bossert et al. (2003)

Figura 3-3. Representação genérica da reação de desalogenação catalisada por microrganismos.

A desalogenação do PCB é amplamente disseminada em ambientes anaeróbios, tornando a desalogenação redutiva a principal via de remoção de cloro do PCB (WIEGEL; WU, 2000).

Entretanto, quanto maior a concentração de cloro, maior é a energia necessária para sua remoção (DOBBINS, 1995). A localização do cloro altera as características de ressonância dos compostos, bem como a densidade elétrica de sítios específicos (FURUKAWA, 1986). Ademais, a posição do cloro no anel aromático afeta sua remoção, já que essa posição modifica diretamente a afinidade das enzimas participadoras do processo de degradação (FURUKAWA, 1986; SYLVESTRE; SONDOSSI, 1994; BEDARD, 2014).

Diferentes microrganismos são responsáveis pelas diferentes atividades de desalogenação redutiva (Figura 3-4) e vários fatores ambientais, tais como doadores e receptores de elétrons, podem influenciar a extensão e taxa de desalogenação. Estes efeitos são devido à especificidade das bactérias 
que se tornam ativas, bem como as complexas interações entre os microrganismos da comunidade (KUMAR, 2004).

(a)

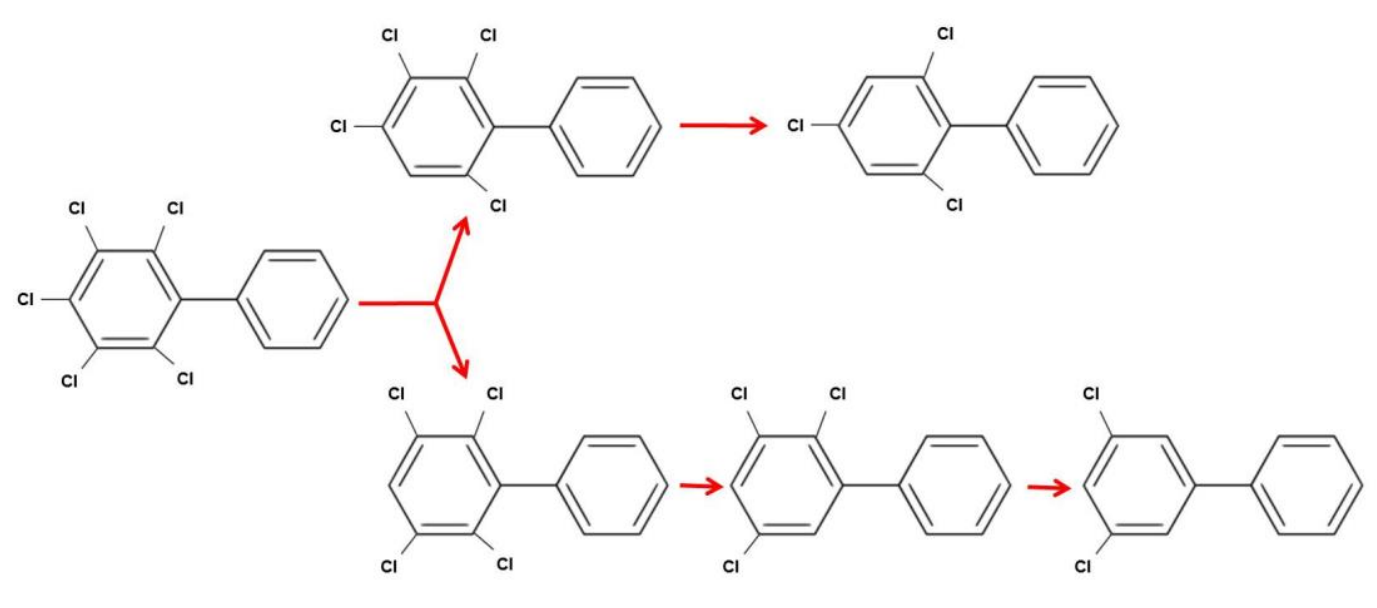

(b)

Fonte adaptado de Pieper; Seeger (2008)

Figura 3-4 Desalogenação anaeróbia redutiva de 2,3,4,5,6-pentaclorobifenil. (a) Desalogenação redutiva na posição meta mediada por Dehalococcoides ethenogenes 195. (b) Desalogenação na posição orto mediada pela bactéria $0-17$.

\subsection{Análise de toxicidade anaeróbia}

Por meio da análise de toxicidade anaeróbia (Anaerobic Toxicity Assay ou ATA) é possível obter indicações da versatilidade, resistência e limitação da comunidade metanogênica (TRZCINSKI; OFOEGBU; STUCKEY, 2012). O termo análise de toxicidade anaeróbia (ATA) foi primeiro proposto por Jeris; McCarty (1965). Esses bioensaios relativamente simples podem ser realizados na maioria dos laboratórios de pesquisa, sem a necessidade de equipamento sofisticado (JERIS; MCCARTY, 1965). A ATA mede o efeito adverso de um composto sobre a taxa de produção total de biogás ou consumo de receptor de elétrons. No caso da metanogênese, esta taxa é dada por uma porcentagem da inibição da produção de metano. Neste trabalho, o conceito de ATA será também extrapolado para a comunidade desnitrificante, no qual esta taxa será estipulada como porcentagem do consumo de nitrato.

Devido à preocupação com a contaminação ambiental, grande atenção tem sido dada às propriedades cancerígenas e tóxicas de poluentes clorados. Compostos halogenados são tóxicos para as arqueias metanogênicas e muitas vezes inibem a metanogênese (MADSEN; AAMAND, 1992). Fang; Chan (1997) avaliaram os efeitos do fenol na metanogênese. Os referidos autores verificaram inibição na atividade metanogênica do lodo com o aumento da concentração de fenol e encontraram valores de $\mathrm{IC}_{50}$ de $1.750,1.000$ e $1.700 \mathrm{mg} . \mathrm{L}^{-1}$ de fenol, respectivamente com acetato, propionato e benzoato como co-substratos.

Sierra-Alvarez; Lettinga (1991) realizaram ensaio de toxicidade anaeróbia e avaliaram a inibição de 34 diferentes compostos aromáticos sobre a comunidade metanogênica acetoclástica. Estes 
autores identificaram que o clorobenzeno, metoxibenzeno e benzaldeído foram os compostos mais tóxicos com $\mathrm{IC}_{50}$ de $3,4 \mathrm{mM}, 4,2 \mathrm{mM}$ e 5,2 $\mathrm{mM}$, respectivamente.

Como mostrado por Kaya; Imamoglu; Sanin (2013b), existe relação entre as concentrações de PCB e produção de metano. A produção de metano sofreu redução significativa e proporcional ao aumento da concentração de PCB 118 em reatores em batelada, inoculado com lodo misto (anaeróbio e lodos ativados) sem adição de co-substratos. Este autores encontraram redução de 9,3\%, 15,6\% e 17,8\% para $10 \mathrm{mg} . \mathrm{L}^{-1}, 20 \mathrm{mg} . \mathrm{L}^{-1}$ e $30 \mathrm{mg} . \mathrm{L}^{-1}$ de PCB 118 em 65 dias de operação.

A posição do cloro no anel aromático do PCB afeta sua remoção (FURUKAWA, 1986; SYLVESTRE; SONDOSSI, 1994) e a concentração do tóxico pode influenciar na extensão e na taxa de degradação do PCB (KUMAR, 2004). Assim, a avaliação de como o PCB afeta o metabolismo microbiano é necessária para que maior eficiência de remoção de PCB seja alcançada.

\subsection{Metabolismo Metanogênico}

A metanogênese é uma das principais vias metabólicas nos sistemas anaeróbios (ZWIERNIK; QUENSEN III; BOYD, 1998) e sob condição fermentativa-metanogênica, a matéria orgânica é degradada por interações entre microrganismos fermentativos, acetogênicos e metanogênicos (STAMS, 1994). As arqueias metanogênicas utilizam número limitado de substratos que incluem $\mathrm{H}_{2} / \mathrm{CO}_{2}$, formiato, acetato e alguns outros substratos, como metanol e metilaminas (VOGELS; KELTJENS; VAN DER DRIFT, 1988; JONES, 1991; DWORKIN et al., 2006). Devido a esta restrição do metabolismo metanogênico, os compostos orgânicos são degradados no ambiente anaeróbio pela associação de microrganismos fermentadores, acetogênicos e metanogênicos (STAMS, 1994; KOENIG; LEE; MANEFIELD, 2014).

A comunidade microbiana que vive em associação desenvolveram mecanismos moleculares para estabelecer essas parcerias e melhorar a comunicação interespécies, resultando em eficientes cooperações metabólicas (KOUZUMA; KATO; WATANABE, 2015).

A capacidade de desalogenação do PCB pelas arqueias metanogênicas foi demonstrado por Ye et al. (1995). Estes autores avaliaram a degradação de PCB com microbiota metanogênica de sedimentos, etanol como co-substrato e arocloro $1242\left(400 \mu \mathrm{g} \cdot \mathrm{g}^{-1}\right)$. A partir dos resultados, pode-se observar diminuição entre 56\% e 78\% dos congêneres presentes no arocloro 1242.

Entretanto, esta evidencia não foi relatada por nenhum outro trabalho subsequente, e atualmente há um consenso de que as arqueias metanogênicas não são responsáveis pela remoção de cloro do PCB apesar da desalogenação redutiva ocorrer preferencialmente em condições fermentativas-metanogênicas ( RHEE et al., 1993; KIM; RHEE, 1997; ZWIERNIK; QUENSEN III; BOYD, 1998; FAVA; GENTILUCCI; ZANAROLI, 2003; BABA et al., 2007; D'ANGELO; NUNEZ, 2010; ZANAROLI et al., 2010).

A desalogenação redutiva do PCB em sedimentos sob condição fermentativa-metanogênica foi extensivamente estudada e pode ocorrer tanto em ambientes marinhos, quanto dulcícola (QUENSEN III; TIEDJE; BOYD, 1988; ABRAMOWICZ, 1990; ALDER et al., 1993; BOYLE et al., 1993; RHEE et al., 1993; OEFJORD; PUHAKKA; FERGUSON, 1994; HOLOMAN et al., 1998; CHANG; LIU; YUAN, 2001; FAVA; GENTILUCCI; ZANAROLI, 2003; BABA et al., 2007; ZANAROLI et al., 
2010). A partir desses trabalhos pode-se concluir que a associação metanogênese e desalogenação é uma importante associação para que ocorra altas taxas de remoção de cloro do PCB (BERTIN et al., 2011).

O papel dos organismos anaeróbios na remoção de cloro do PCB foi primeiramente evidenciado por Brown Jr et al. (1987), desde então alguns microrganismos responsáveis pela desalogenação redutiva foram isolados e identificados (HOLLIGER; WOHLFARTH; DIEKERT, 1998). Entre eles estão Dehalobacter sp. (YOSHIDA et al., 2009; WANG; HE, 2013a), algumas bactérias do filo Chloroflexi, como Dehalobium chlorocoercia DF1 (WU et al., 2002; PAYNE; MAY; SOWERS, 2011; KJELLERUP; PAUL; GHOSH, 2012; PAYNE et al., 2013), Dehalococcoides mccartyi JNA (LÖFFLER et al., 2013), anteriormente denominado Dehalococcoides ethenogenes 195, (FENNELL et al., 2004; WANG; HE, 2013a, 2013b; LAROE; FRICKER; BEDARD, 2014), Dehalogenimonas (LIANG et al., 2014; WANG; HE, 2013a), e ainda alguns microrganismos relacionados, porém distintos do filo Chloroflexi, como a bactéria o-17 (MAY et al., 2006; CUTTER et al., 2001) e SF-1 (ZANAROLI et al., 2012a).

Fagervold et al. (2005) verificaram que espécies do grupo Chloroflexi são reconhecidamente capazes de degradar anaerobiamente as bifenilas policloradas por desalogenação redutiva na presença de acetato, proprianato e butirato como co-substratos (2,5 mM cada) e três congêneres de PCB, 91, 101 e 132 (50 mg.L $\mathrm{L}^{-1}$ cada).

Wu et al. (2002) identificaram Dehalobium chlorocoercia DF1 em culturas com altas taxas de desalogenação de PCB 61 a PCB 23 (60\% de desalogenação em 46 dias). A desalogenação ocorreu quando formiato ou $\mathrm{H}_{2}-\mathrm{CO}_{2}$ foi fornecido.

Yoshida et al. (2009) demonstraram pela primeira vez que espécies de Dehalobacter eram responsáveis pela desalogenação redutiva do PCB $21 \mathrm{com}$ acetato como co-substrato $(5 \mathrm{mM})$. Estes autores relataram nova via de desalogenação com a conversão do PCB 21 (de 4,8 $\pm 1,3 \mathrm{mM}$ a 0,18 $\pm 0,17$ $\mathrm{mM}$ ) em PCB 3, via 3,4-diclorobifenil.

LaRoe et al. (2014) isolaram Dehalococcoides mccartyi JNA enriquecido e mantido com Arocloro $1260(135 \mu \mathrm{M})$ e acetato como co-susbrato. Em 124 dias, Dehalococcoides mccartyi JNA removeu $14 \%, 51 \%$ e $20 \%$ dos penta-, hexa- e heptaclorobifenil na mistura, sendo a primeira cultura pura capaz de realizar esta extensa desalogenação do PCB.

No estudo de Wang; He (2013b), 18 microcosmos de solo e sedimento foram incubados com Arocloro 1260 (30 mg.L. $\left.\mathrm{L}^{-1}\right)$ e lactato como co-substrato (10 mM). Após um ano, os autores verificaram taxas significativas de desalogenação com distintos padrões em 10 dos microcosmos. Entre os padrões de desalogenação, a remoção de cloro dos hepta- e hexachlorobifenil foi bem expressiva, de 30\% e 59\%, respectivamente. Por meio da análise filogenética verificou-se filiação com espécies de Dehalogenimonas e Dehalococcoides.

Zanaroli et al. (2012a) identificaram microrganismos de sedimento marinho capazes de remover cloro do Arocloro 1254 (1.000 mg. $\left.\mathrm{L}^{-1}\right)$ na presença de formiato, acetato, propriananto e butirato $(20 \mathrm{mM}$ cada) como co-substratos. A cultura foi denominada de SF-1 e responsável pela desalogenação de 75\% de congêneres penta-, hexa- e heptaclorobifenil em 30 semanas.

Deste modo, metodologias mais eficientes e rápidas na identificação de organismos que possam ser responsáveis pela desalogenação do PCB tornam-se ferramentas potencialmente eficazes. No 
entanto, poucos estudos tiveram como objetivo determinar a diversidade microbiana de consórcios anaeróbios após a exposição PCB utilizando sequenciamento massivo de alto rendimento (LEIGH et al., 2007a; GOMES et al., 2014).

Além disso, o sedimento foi o primeiro inóculo utilizado no estudo de desalogenação do PCB por ter sido o local onde a desalogenação anaeróbia foi primeiramente evidenciada (BROWN JR et al., 1987) e, apesar do processo anaeróbio ocorrer naturalmente em vários sedimentos aquáticos, baixos rendimentos em relação as condições de laboratório indicam que novos processos que aplicam consórcios anaeróbios podem reduzir custos e melhorar a taxa desalogenação do PCB (ZANAROLI et al., 2012b). Neste sentido, estudos com biorreatores anaeróbios ganharam evidencia na desalogenação do PCB (Tabela 3-2). 
Tabela 3-2 Resultados de remoção de PCB em reatores anaeróbios.

\begin{tabular}{|c|c|c|c|c|c|c|c|}
\hline PCB & $\begin{array}{l}\text { Concentr } \\
\text { ação de } \\
\text { PCB }\end{array}$ & $\begin{array}{c}\text { Co- } \\
\text { substrato }\end{array}$ & Inóculo & $\begin{array}{l}\text { Tipo de } \\
\text { reator }\end{array}$ & $\begin{array}{l}\text { Tempo } \\
\text { de } \\
\text { encuba } \\
\text { ção } \\
\end{array}$ & Eficiência & Referencia \\
\hline $\begin{array}{l}\text { PCB 10; } \\
\text { PCB 28; } \\
\text { PCB 52; } \\
\text { PCB 138; } \\
\text { PCB 153; } \\
\text { PCB 180; }\end{array}$ & $0,7 \mathrm{mg} \cdot \mathrm{L}^{-1}$ & $\begin{array}{l}\text { Etanol } \\
(460 \\
\left.\text { mg. } \mathrm{L}^{-1}\right) \mathrm{e} \\
\text { formiato de } \\
\text { sódio }(680 \\
\left.\mathrm{mg} . \mathrm{L}^{-1}\right)\end{array}$ & $\begin{array}{l}\text { Uasb } \\
\text { proveniente de } \\
\text { avicultura não- } \\
\text { adaptado }\end{array}$ & batelada & 60 dias & $\begin{array}{c}\text { De } 0,7 \text { a } \\
0,2 \\
m g \cdot \mathrm{mL}^{-1}\end{array}$ & Gomes et al. (2014) \\
\hline PCB 118 & $\begin{array}{c}1,10,20 \\
\mathrm{e} \\
30 \mathrm{mg} \cdot \mathrm{L}^{-1}\end{array}$ & 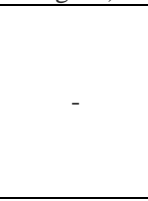 & $\begin{array}{l}\text { Lodos ativados e } \\
\text { lodo anaeróbio } \\
\text { proveniente de } \\
\text { de digestor } \\
\text { mesofilico não } \\
\text { adaptado } \\
\end{array}$ & batelada & 65 dias & $\begin{array}{c}16,5 \% \\
8,8 \%, 5,3 \% \\
\text { e } 3,1 \%\end{array}$ & $\begin{array}{l}\text { Kaya; Imamoglu; } \\
\text { Sanin (2013a) }\end{array}$ \\
\hline PCB 118 & $\begin{array}{l}1 \text { and } 20 \\
\text { mg. } \mathrm{L}^{-1}\end{array}$ & - & $\begin{array}{l}\text { Lodos ativados e } \\
\text { lodo anaeróbio } \\
\text { proveniente de } \\
\text { de digestor } \\
\text { mesofilico não } \\
\text { adaptado } \\
\end{array}$ & batelada & $\begin{array}{l}159 \\
\text { dias }\end{array}$ & $12 \%, 22 \%$ & $\begin{array}{l}\text { Kaya; Imamoglu; } \\
\text { Sanin (2013b) }\end{array}$ \\
\hline $\begin{array}{c}\text { Arocloro12 } \\
60 \\
\end{array}$ & $\begin{array}{c}200 \\
\mathrm{mg} \cdot \mathrm{L}^{-1}\end{array}$ & etanol & $\begin{array}{l}\text { Biomassa } \\
\text { anaerobia }\end{array}$ & batelada & 3 dias & $85 \%$ & Cline et al. (2010) \\
\hline $\begin{array}{l}\text { PCB 28; } \\
\text { PCB 52; } \\
\text { PCB 101; } \\
\text { PCB 138; } \\
\text { PCB 153; } \\
\text { PCB 180 }\end{array}$ & $\begin{array}{c}0,5 \\
\mathrm{mg} \cdot \mathrm{kg}^{-1}\end{array}$ & - & Lodos ativados & $\begin{array}{l}\text { Digestor } \\
\text { anaerobio }\end{array}$ & $\begin{array}{l}204 \\
\text { dias }\end{array}$ & $\begin{array}{c}\text { Entre } 33 \% \\
\text { e } 58 \%\end{array}$ & $\begin{array}{l}\text { El-Hadj et al. } \\
\qquad(2007)\end{array}$ \\
\hline $\begin{array}{l}\text { Arocloro } \\
1242\end{array}$ & $\begin{array}{c}\text { Entre } \\
0,32 \mathrm{e} \\
12,0 \mathrm{mg} \\
\mathrm{L}^{-1} \cdot \mathrm{dia}^{-1} \\
\end{array}$ & $\begin{array}{l}\text { Extrato de } \\
\text { levedura } \\
\left(2 \mathrm{~g} \cdot \mathrm{L}^{-1}\right)\end{array}$ & Lodo anaerobio & UASB & 202 & $\begin{array}{c}\text { de } 0,6 \mathrm{mg} \\
\text { Arocloro. } \\
\mathrm{gSSV}^{-1} \text {. } \\
\mathrm{dia}^{-1}\end{array}$ & $\begin{array}{c}\text { Tartakovsky; } \\
\text { Hawari; Guiot } \\
\text { (2000) }\end{array}$ \\
\hline РCB 61 & $1 \mathrm{mg} \cdot \mathrm{L}^{-1}$ & $\begin{array}{l}\text { Acetato, } \\
\text { piruvato e } \\
\text { lactato de } \\
\text { sódio ( } 20 \\
\text { mM cada) }\end{array}$ & $\begin{array}{l}\text { Biomassa mista } \\
\text { lodo anaerobio e } \\
\text { sedimento) } \\
\text { adaptada com } \\
\text { clorofenol }\end{array}$ & batelada & 40 & $100 \%$ & $\begin{array}{c}\text { Chang; Chou; Yuan } \\
\text { (1999) }\end{array}$ \\
\hline
\end{tabular}

Tartakovsky; Hawari; Guiot (2000) verificaram a desalogenação de Arocloro1242 em reatores contínuos UASB mesofílicos, com tempo de detenção hidráulica de 5 dias. Os autores verificaram que a taxa máxima de desalogenação foi de $0,6 \mathrm{mg}$ Arocloro. $\mathrm{gSSV}^{-1} \cdot \mathrm{dia}^{-1}$, para concentração média de PCB de 2,0 mg Arocloro. $\mathrm{gSSV}^{-1} . \mathrm{dia}^{-1}$.

A desalogenação do PCB 118 em reatores em batelada metanogênicos foi avaliada por Kaya; Imamoglu; Sanin (2013a). Os reatores sob condição mesofílica foram inoculados com mistura de lodo anaeróbio e lodos ativados por 152 dias. Cerca de 12\% e 22\% de remoção de PCB 118 foram atingidos proporcionalmente às suas concentrações iniciais de $1 \mathrm{mg} . \mathrm{L}^{-1}$ e $20 \mathrm{mg} . \mathrm{L}^{-1}$, respectivamente.

Gomes et al. (2014) avaliaram a degradação de seis congêneres de PCB (PCB 10, 28, 52, 132, $153,180)$ em reatores em batelada sob condições metanogênicas. Os reatores foram inoculados com lodo proveniente de reator anaeróbio de fluxo ascendente (UASB). Etanol (460 mg. $\left.\mathrm{L}^{-1}\right)$ e formiato de sódio $\left(680 \mathrm{mg} . \mathrm{L}^{-1}\right)$ foram utilizados como co-substratos. Os autores verificaram ao final de 60 dias, remoção de PCB de 0,7 a $0,2 \mathrm{mg} \cdot \mathrm{mL}^{-1}$ para $0,7 \mathrm{mg} \cdot \mathrm{L}^{-1}$ de PCB inicial. Desse modo pode-se afirmar que o estabelecimento de comunidade complexa favorecida pelas condições hidrodinâmicas dos reatores anaeróbios podem ser favoráveis à desalogenação do PCB, bem como, o conhecimento acerca dos microrganismos provavelmente responsáveis pelo metabolismo do composto. 


\subsection{Metabolismo Desnitrificante}

A desnitrificação é um processo respiratório no qual as bactérias reduzem nitrato $\left(\mathrm{NO}_{3}^{-}\right)$ou nitrito $\left(\mathrm{NO}_{2}{ }^{-}\right)$, como receptor final de elétrons a óxidos gasosos (óxido nítrico, $\mathrm{NO}$ e óxido nitroso, $\mathrm{N}_{2} \mathrm{O}$ ), o qual podem ser reduzidos a gás nitrogênio (Figura 3-5) (KNOWLES, 1982; GHAFARI; HASAN; AROUA, 2008). Na desnitrificação heterotrófica, compostos de carbono são utilizadas pelas bactérias desnitrificantes como fonte de carbono e elétrons. Na desnitrificação autotrófica compostos inorgânicos reduzidos (sulfeto, ferro e hidrogênio) são utilizados como fonte de elétrons e carbono inorgânico para biossíntese (KOROM, 1992; GHAFARI; HASAN; AROUA, 2008).

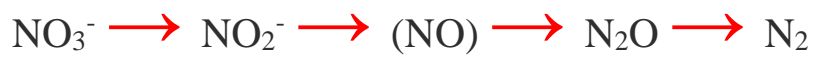

Fonte adaptado de Knowles (1982)

Figura 3-5 Desnitrificação completa ou redução de nitrato a nitrogênio gasoso.

Sob condição ótima, na desnitrificação ocorre a conversão de mais de $95 \%$ de nitrato e nitrito em nitrogênio gasoso (CHIU; CHUNG, 2003). Um dos parâmetros que interferem diretamente na redução bioquímica de nitrato e nitrito é a fonte de carbono MONTEITH; BRIDLE; SUTTON, 1980; SKRINDE; BHAGAT, 1982; (HER; HUANG, 1995), sendo que tanto a escassez, quanto o excesso podem afetar a eficiência de desnitrificação.

A degradação anaeróbia de compostos tóxicos pode ser ampliada com a adição de receptores de elétrons adequados e, a utilização de nitrato permite acoplar a desnitrificação à degradação de compostos aromáticos tais como, fenol, clorofenol, BTEX, tolueno e PCB (PROVIDENTI; LEE; TREVORS, 1993; SANFORD; TIEDJE, 1997; CHANG; CHOU; YUAN, 1999; SARFARAZ et al., 2004; GUSMÃO et al., 2007; MARTÍNEZ-HERNÁNDEZ et al., 2009; MARTÍNEZ-GUTIÉRREZ et al., 2012).

Baseado nas equações de termodinâmica, a oxidação completa de compostos organoclorados aliado a redução de nitrato pode ser um processo energeticamente favorável (JANSSEN; OPPENTOCHT; POELARENDS, 2003). Alguns isolados, pertencentes aos gêneros Thauera, Pseudomonas, e Ochrobacterium mineralizaram 3-clorobenzoato e utilizaram este composto como a única fonte de carbono e energia sob condições desnitrificantes (SONG; PALLERONI; HÄGGBLOM, 2000). Comamonas testosteroni, (TAMAOKA; HA; KOMAGATA, 1987), Pseudomonas putida, Desulfitobacterium sp, e Citrobacter freunddi foram capazes de mineralizar o anel bifenil além de realizar a desalogenação do PCB (PETTIGREW et al., 1990; BOYLE et al., 1992; SYLVESTRE, 1980; VOS et al., 2009).

Pettigrew e colaboradores (1990) identificaram consórcio microbiano proveniente de lodo de estação de tratamento de esgoto municipal capaz de mineralizar PCB 3 e realizar a desalogenação do PCB 15. Neste estudo, o consorcio microbiano foi cultivado em meio contendo PCB 3 (100 mg.. $\left.\mathrm{L}^{-1}\right)$ e bifenil $\left(10 \mathrm{mg} . \mathrm{L}^{-1}\right)$ como fonte de carbono e nitrato de sódio $\left(4 \mathrm{~g} . \mathrm{L}^{-1}\right)$. O consórcio era composto por três isolados: C. testosteroni, o qual mediou a quebra do bifenil mono e diclorado a ácido clorobenzóico, Arthrobacter sp., que realizou a degradação do ácido clorobenzóico, e por último, P. putida, cujo papel no consórcio não foi elucidado. 
D. dehalogenans foi capaz de realizar a desalogenação redutora de PCB-OH ou PCB hidroxilado (metabólito da degradação do PCB) mas não de PCB não modificado (WIEGEL; ZHANG; WU, 1999). Os resultados apresentados indicam que este grupo não seja capaz de iniciar a desalogenação do PCB, porém, sua participação é importante nas etapas intermediarias dessa degradação.

Poucos estudos avaliaram a degradação de PCB sob condições anóxicas e apenas dois avaliaram essa degradação em reatores biológicos (CHANG; CHOU; YUAN, 1999; GRISHEHENKOV; SLEPEN'KIN; BORONIN, 2002).

Chang et al. (1999) analisaram a degradação do PCB 61 (1,0 mg. $\left.\mathrm{L}^{-1}\right)$ sob condição desnitrificante em reatores em batelada com acetato, piruvato e lactato de sódio ( $20 \mathrm{mM}$ cada) como cosubstratos. Num período de 40 dias de operação, todo o nitrato foi consumido $\left(\mathrm{NO}_{3}\right.$ inicial de $\left.20 \mathrm{mM}\right)$ e $0,2 \mathrm{mg} . \mathrm{L}^{-1}$ do PCB foi removido.

Grishchenkov et al. (2002) isolaram C. freunddi em meio sintético suplementado com bifenil proveniente de cultura enriquecida do solo e resíduo industrial contaminado. Os autores verificaram que a linhagem foi capaz de degradar o anel aromático sob condição anóxica, concomitantemente com a redução de nitrato. Para concentração inicial de $150 \mathrm{mg} . \mathrm{L}^{-1}$, em 3 dias verificou-se remoção média de $27 \%$ de bifenil, e quando a concentração inicial foi de $250 \mathrm{mg} . \mathrm{L}^{-1}$, observou-se remoção de $17 \%$ em 21 dias.

Por meio dos trabalhos apresentados, mais estudos acerca da utilização e metabolismo destes compostos pelos organismos desnitrificantes precisam ser elaboradas, caracterizando assim, uma metodologia inovadora na degradação do PCB.

\subsection{Extração e análise cromatográfica do PCB}

Metodologias analíticas para análise quantitativa de PCB a partir de amostras ambientais são especialmente difíceis devido à complexidade das misturas de congêneres, interferências de matriz e necessidade de baixos limites de detecção. Assim, extração de PCB de amostras ambientais, como amostras de biorreatores, é um desafio significativo que exige uma eficaz preparação da amostra antes da análise.

A metodologia mais utilizada para a análise e quantificação de PCB é a extração líquido/líquido. Entretanto, Llompart et al. (1998), comparam a técnica líquido/líquido com o Solid Phase Microextraction (SPME), e concluíram que com resultados similares entre as duas técnicas, todavia por meio da aplicação da técnica de SPME obtiveram maior rapidez e obtenção de menores limites de detecção.

O SPME vem sendo usada em muitas pesquisas com grande eficácia. Desenvolvida por Arthur; Pawliszyn (1990), esta técnica envolve a preparação da amostra sem a necessidade de adição de solvente integrando a amostragem, o isolamento e a concentração em única etapa.

Por meio da aplicação do SPME tem-se a eliminação de alguns problemas de extração, como a necessidade de grande volume amostral e a utilização de solvente, tanto para amostragem como para a extração. Conjuntamente tem-se algumas vantagens, como a redução do tempo de extração, maior praticidade e sensibilidade comparando com métodos clássicos, como a extração líquido/líquido (ARTHUR; PAWLISZYN, 1990). 
No SPME, uma fibra de pequeno diâmetro revestida com uma fase estacionária é imersa em amostra aquosa ou introduzida no headspace. Os analitos são extraídos na fase estacionária da fibra, e posteriormente, dessorvidos termicamente na coluna do injetor do cromatógrafo gasoso. As pequenas dimensões da fibra $(100-300 \mu \mathrm{m})$ são convenientes para injeções no cromatógrafo.

Ademais, a simplicidade do uso, o tempo de processamento relativamente pequeno, a utilização de quantidades menores de amostra e a possibilidade de reutilização da fibra, fazem com que o SPME seja opção atraente para diversas análises ambientais do PCB (Tabela 3-3). 
Tabela 3-3. Aplicação da técnica de SPME para avaliar amostras ambientais com PCB.

\begin{tabular}{|c|c|c|c|c|c|}
\hline Tipo de fibra & $\begin{array}{l}\text { Tempo / } \\
\text { Temperatura } \\
\text { extração }\end{array}$ & $\begin{array}{c}\text { Tempo/ Temperatura de } \\
\text { dessorção }\end{array}$ & Volume amostral & Composto & Referencia \\
\hline PDMS $15 \mu \mathrm{m}$ & $\begin{array}{c}60 \mathrm{~min} / \text { Temperatura } \\
\text { ambiente }\end{array}$ & $1 \mathrm{~min} / 300^{\circ} \mathrm{C}$ & & $\begin{array}{l}\text { PCB } 18, \\
87 \\
\end{array}$ & $\begin{array}{c}\text { Potter; Pawliszyn, } \\
\text { (1994) }\end{array}$ \\
\hline $\begin{array}{l}\text { PDMS-DVB } \\
65 \mu \mathrm{m} \\
\text { PDMS } 100 \mu \mathrm{m} \\
\end{array}$ & $60 \mathrm{~min} / 100^{\circ} \mathrm{C}$ & $5 \mathrm{~min} / 270^{\circ} \mathrm{C}$ & $100 \mathrm{~mL}$ & $\begin{array}{c}\text { PCB } 28,52,101,105,118 \\
138,153,156,180\end{array}$ & Landín et al. (2001) \\
\hline $\begin{array}{c}\text { PDMS } 100 \\
\mu \mathrm{m} \\
\text { PA } 85 \mu \mathrm{m} \\
\text { PDMS/DVB } \\
65 \mu \mathrm{m} \\
\text { CW/DVB } 65 \\
\mu \mathrm{m} \\
\text { CAR/PDMS } \\
75 \mu \mathrm{m} \\
\end{array}$ & $\begin{array}{l}150 \mathrm{~min} / \\
\text { Temperatura } \\
\text { ambiente }\end{array}$ & $10 \mathrm{~min} / 260^{\circ} \mathrm{C}$ & $1.5 \mathrm{~mL}$ & $\begin{array}{c}\text { PCB } 8,28,20,35,52,118 \\
101,138,153,180\end{array}$ & Valor et al. (2001) \\
\hline PDMS $30 \mu \mathrm{m}$ & $45 \mathrm{~min} / 30^{\circ} \mathrm{C}$ & $1 \mathrm{~min} / 270^{\circ} \mathrm{C}$ & $30 \mathrm{~mL}$ & PCB 10,180 & Cortazar et al. (2002) \\
\hline $\begin{array}{c}\text { PDMS } 100 \\
\mu \mathrm{m} \\
\end{array}$ & $60 \mathrm{~min} / 72^{\circ} \mathrm{C}$ & $5 \mathrm{~min} / 274^{\circ} \mathrm{C}$ & & $\begin{array}{c}\text { PCB } 10,28,52,138,153, \\
180\end{array}$ & Rodil et al. (2005) \\
\hline $\begin{array}{c}\text { PDMS } 100 \\
\mu \mathrm{m} \\
\text { PDMS-DVB } \\
65 \mu \mathrm{m} \\
\end{array}$ & $\begin{array}{c}30 \mathrm{~min} / \text { Temperatura } \\
\text { ambiente }\end{array}$ & $3 \mathrm{~min} / 250^{\circ} \mathrm{C}$ & $10 \mathrm{~mL}$ & $\begin{array}{c}\text { PCB } 10,28,52,138,153, \\
180\end{array}$ & Basheer et al. (2007) \\
\hline $\begin{array}{l}\text { PDMS } 100,30 \\
\text { e } 7 \mu \mathrm{m} \\
\text { PDMS/DVB } \\
65 \mu \mathrm{m}\end{array}$ & $30 \mathrm{~min} / 60^{\circ} \mathrm{C}$ & $5 \mathrm{~min} / 260^{\circ} \mathrm{C}$ & $2 \mathrm{~mL}$ & $\begin{array}{c}\text { PCB } 8,18,28,44,52,66 \\
77,101,105,118,126,128 \\
138,153,170,180,187 \\
195,206 \text { e } 209\end{array}$ & $\begin{array}{l}\text { Derouiche et al. } \\
\qquad(2007)\end{array}$ \\
\hline $\begin{array}{l}\text { PDMS } 100 \\
\mu \mathrm{m} \\
\text { PDMS-DVB } \\
65 \mu \mathrm{m}\end{array}$ & $50 \mathrm{~min} / 95^{\circ} \mathrm{C}$ & $5 \mathrm{~min} / 280^{\circ}$ & $5 \mathrm{~mL}$ & $\begin{array}{c}\text { PCB } 28,52,74,101,118 \\
128,138,153,156,170,180 \\
\text { e } 187\end{array}$ & Kowalski et al. (2013) \\
\hline \multicolumn{6}{|c|}{$\begin{array}{c}\text { PDMS: Polidimetilsiloxano } \\
\text { PDMS/DVB: Polidimetilsiloxano/ divinilbenzeno } \\
\text { CW/DVB: Carbowax/Divinilbenzeno } \\
\text { /PDMS (carboxen/PDMS): Carboxen/Polidimetilsiloxano }\end{array}$} \\
\hline
\end{tabular}

Potter; Pawliszyn (1994) utilizaram esta técnica para avaliar dois congêneres de PCB (PCB 18 e PCB 87) em concentração de $10^{-5} \mathrm{mg} . \mathrm{L}^{-1} \mathrm{em}$ amostras de água. Os autores concluíram que depois de 60 minutos de exposição da fibra, a concentração do PCB entra em equilíbrio com a fibra, entretanto, com 10 minutos de exposição a análise por meio de GC é eficiente.

Kowalski et al. (2013) compararam a extração de PCB com duas fibras, PDMS $100 \mu \mathrm{m}$ e PDMS/DVB $65 \mu \mathrm{m}$. Verificou-se que para a fibra PDMS/DVB $65 \mu \mathrm{m}$ maior eficiência, porém maior variação na reprodutibilidade amostral, resultando na escolha da fibra PDMS $100 \mu \mathrm{m}$ como ideal na extração do PCB. Landín et al. (2001) avaliaram 9 congêneres (PCB 28, PCB 52, PCB 101, PCB 105, PCB 118, PCB 138, PCB 153, PCB 156, PCB 180) em concentrações que variaram de 7,22 mg.L-1 a 28,80 mg. $\mathrm{L}^{-1} \mathrm{em}$ amostras de água doce e salina, comparando dois tipos de fibras (PDMS 100 $\mu \mathrm{m}$ e PDMS/DVB 65 $\mu \mathrm{m}$ ). Os autores concluíram que por meio da utilização da fibra PDMS/DVB $65 \mu \mathrm{m}$ obteve-se maior eficiência de extração do PCB pelo headspace.

Como apresentado em trabalhos anteriores, a técnica de extração de PCB por meio do SPME é promissora e no presente trabalho foi avaliada na análise ambiental de reatores em batelada. Para tanto, diferentes tipos de fibra, adição de $\mathrm{NaCl}$, diferentes concentrações de PCB e tempos de extração foram avaliados. 


\subsection{Considerações finais}

Por meio de trabalhos apresentados anteriormente sobre as características do PCB, sua extensa produção mundial, seus efeitos biológicos, processos de remoção e degradação, nota-se que especial atenção deve ser dada ao seu destino.

Diversas são as pesquisas que visam desenvolver possibilidades tecnológicas para degradar PCB no ambiente. Para o melhor entendimento e aperfeiçoamento dos processos biológicos, ainda deverão ser realizadas pesquisas acerca dos diversos fatores que interferem em sua degradação, tais como o processo empregado, presença de determinados microrganismos, produtos e possível inibição dos microrganismos.

Em trabalhos anteriores a remoção de cloro por bactérias anaeróbias não foram evidenciadas em menos de quatro meses com consórcio não adaptado (CHANG; CHOU; YUAN, 1999), entretanto em recente trabalho (GOMES et al., 2014) evidenciou-se degradação de PCB em 60 dias para consócio fermentativo-metanogênico não adaptado.

Além disso, a carência de receptores de elétrons em condição anaeróbia é o principal fator limitante do crescimento microbiano. Consequentemente, qualquer microrganismo que possa utilizar receptor de elétrons abundante no meio, como o nitrato, poderia ter uma vantagem em relação aos outros utilizadores de PCB em meio anaeróbio/anóxico. Tal tecnologia, pouco estudada na remoção de PCB, foi utilizada eficientemente no tratamento de outros compostos aromáticos e clorados.

Mediante o exposto, o presente trabalho teve como principal objetivo avaliar a remoção do PCB com consórcio não adaptado comparando a comunidade anaeróbia (metanogênica) e anóxica (desnitrificante) na eficiência de remoção do PCB. Investigou-se também neste estudo o comportamento da comunidade metanogênica e desnitrificante em presença de diferentes concentrações de PCB, caracterizando-se a concentração inibitória do PCB para cada consócio e por fím, foi realizada a caracterização da comunidade microbiana, por meio de sequenciamento massivo nos reatores sob condição anaeróbia e anóxica no início e final da operação. 
A execução experimental foi realizada de acordo com as hipóteses elaboradas e a partir da Figura 4-1 é possível observar o delineamento experimental de cada hipótese.

Para responder a Hipótese 1 e avaliar a eficiência e eficácia do SPME como metodologia de análise de PCB foram realizados testes de extração com diferentes tipos de fibras, tempos de extração, adição de $\mathrm{NaCl}$ e volume amostral para determinar as melhores condições cromatográficas a partir da mistura de solução de seis congêneres de PCB.

Ademais, neste estudo foram realizados Ensaio de Inibição Metanogênica e Ensaio de Remoção de PCB sob condição fermentativa-metanogênica para responder a Hipótese 2, no qual foi estabelecida a concentração tóxica de PCB para a comunidade fermentativa-metanogênica e foi avaliada a remoção do PCB e caracterização microbiana sob esta condição.

De modo a responder a Hipótese 3 foram conduzidos Ensaio da Relação ideal Carbono e Nitrogênio, Ensaio de Inibição Desnitrificante e Ensaio de Remoção de PCB sob condição desnitrificante para estabelecer a melhor relação $\mathrm{C} / \mathrm{N}-\mathrm{NO}_{3}{ }^{-}$nos reatores em batelada, a concentração tóxica de PCB para a comunidade desnitrificante e a remoção do PCB e caracterização microbiana sob condição anóxica.

Por fim, a comparação do Ensaio de Remoção de PCB entre as diferentes condições estabelecidas (fermentativa-metanogênica e desnitrificante) foi realizada para responder a Hipótese 4. 
Hipótese 1: o sPME é

uma metodologia eficaz na

avaliação de PCB de amostras de reatores

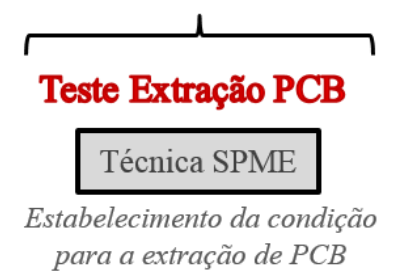

Hipótese 4: A remoção

de $P C B$ e a composição

microbiana foi distinta em cada condicao
Hipótese 2: A condição

fermentativa-metanogênica abriga comunidade resistente a presença

de PCB e capaz de removê-lo

\section{ENSAIO Inibição \\ Metanogênica}

Meio sintético+
co-substrato
(Etanol e
formiato) + PCB

Estabelecimento da

concentração

inibitória de $P C B$

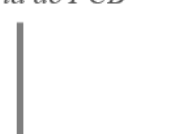

Hipótese 3: A condição desnitrificante abriga comunidade resistente a presença de $\mathrm{PCB}$ e capaz de removê-lo

\section{ENSAIO Relação C/N ideal}

Meio sintético+Etanol

$$
+\mathrm{PCB}+\text { nitrato }
$$

Estabelecimento da relação ideal de C/N

para a comunidade desnitrificante na preseça

$$
\text { de } P C B
$$

ENSAIO Inibição

Desnitrificante

Meio sintético+Etanol $+\mathrm{PCB}+$ nitrato

Estabelecimento da concentração inibitória de $P C B$

\section{ENSAIO Remoção de PCB}

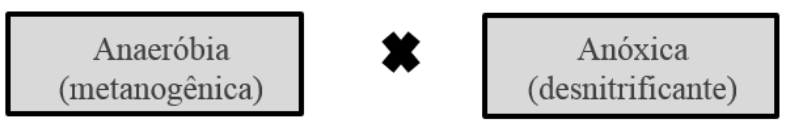

Avaliação da melhor condição para remoção de $P C B$

Caracterização da comunidade microbiana:

Sequenciamento Massivo-

Caracterizar a comunidade do Ensaio de Remoção de PCB

$$
\left(\mathrm{T}_{0} \text { e } \mathrm{T}_{2}\right)
$$

Figura 4-1 Fluxograma experimental dos ensaios em batelada, extração do PCB e caracterização da comunidade microbiana 


\subsection{PCB}

Em todas as etapas do trabalho foi utilizado o PCB na forma de PCB Congener Mix 1 adquiridos pela Sigma-Aldrich ${ }^{\circledR}$. A concentração estoque do PCB foi de $10 \mathrm{mg} \cdot \mathrm{L}^{-1}$ e era composto por:

2,6-Diclorobifenil ou PCB 10;

2,4,4'-Triclorobifenil ou PCB 28;

2,2',5,5'-Tetraclorobifenil ou PCB 52;

2,2',3,4,4',5'-Hexaclorobifenil ou PCB 138;

2,2',4,4',5,5'-Hexaclorobifenil ou PCB 153;

2,2',3,4,4',5,5'-Heptaclorobifenil ou PCB 180;

\subsection{Meio Sintético}

Para os ensaios em batelada sob condição fermentativa-metanogênica e desnitrificante foi utilizado o meio sintético descrito por Angelidaki et al. (2009). A solução A e B foi preparada pela dissolução dos itens da solução em água deionizada (Tabela 4-1 e Tabela 4-2). Posteriormente, esterilizou-se a solução por filtração em sistema Millipore em membrana com porosidade de $0,22 \mu \mathrm{m}$, previamente esterilizado em autoclave a $121^{\circ} \mathrm{C}$ e 1 atm durante 20 minutos.

Tabela 4-1. Solução A utilizada nos ensaio em batelada.

\begin{tabular}{cc}
\hline SOLUÇãO A & $\begin{array}{c}\text { Quantidade }- \text { q.s.p. 1000 } \\
\text { mL de água deionizada }\end{array}$ \\
\hline $\mathrm{NH}_{4} \mathrm{Cl}$ & $100 \mathrm{~g}$ \\
$\mathrm{NaCl}$ & $10 \mathrm{~g}$ \\
$\mathrm{MgCl}_{2} 6 \mathrm{H}_{2} \mathrm{O}$ & $10 \mathrm{~g}$ \\
$\mathrm{CaCl}_{2} 2 \mathrm{H}_{2} \mathrm{O}$ & $5 \mathrm{~g}$ \\
\hline
\end{tabular}

Tabela 4-2 Solução B utilizada nos ensaio em batelada.

\begin{tabular}{cc}
\hline SOLUÇÃO B & $\begin{array}{c}\text { Quantidade - q.s.p. 1000 } \\
\text { mL de água deionizada }\end{array}$ \\
\hline $\mathrm{K}_{2} \mathrm{HPO}_{4}$ & $152,6 \mathrm{~g}$ \\
\hline
\end{tabular}

A solução de resazurina foi utilizada para avaliar o potencial redox nos reatores em batelada e foi preparada pela dissolução em água deionizada (Tabela 4-3).

Tabela 4-3 Solução de resazurina utilizada nos ensaio em batelada

\begin{tabular}{cc}
\hline SOLUÇÃO C & $\begin{array}{c}\text { Quantidade }- \text { q.s.p. } 1000 \\
\mathrm{~mL} \text { de água deionizada }\end{array}$ \\
\hline resazurina & $0,5 \mathrm{~g}$ \\
\hline
\end{tabular}

A solução traço de metais e selenito foi utilizada na preparação dos meios sintéticos em água deionizada (Tabela 4-4). Posteriormente a solução foi submetida a atmosfera de nitrogênio (100\%) por 
20 minutos, e então, procedeu-se a distribuição em frascos de antibióticos (30 mL), também sob condições de anaerobiose. Os frascos foram fechados com tampa de butila, lacrados e esterilizados em autoclave a $121^{\circ} \mathrm{C}$ e $1 \mathrm{~atm}$, por 20 minutos. Os frascos foram armazenados sob refrigeração.

Tabela 4-4 Solução traço de metais e selenito utilizado nos ensaio em batelada

\begin{tabular}{cc}
\hline SOLUÇÃO D: METAIS E SELENITO & $\begin{array}{c}\text { Quantidade - q.s.p. 1000 } \\
\text { mL de água deionizada }\end{array}$ \\
\hline $\mathrm{FeCl}_{2} \cdot 4 \mathrm{H}_{2} \mathrm{O}$ & $2 \mathrm{~g}$ \\
$\mathrm{H}_{3} \mathrm{BO}_{3}$ & $0,05 \mathrm{~g}$ \\
$\mathrm{ZnCl}_{2}$ & $0,05 \mathrm{~g}$ \\
$\mathrm{CuCl}_{2} \cdot 2 \mathrm{H}_{2} \mathrm{O}$ & $0,038 \mathrm{~g}$ \\
$\mathrm{MnCl}_{2} \cdot 4 \mathrm{H}_{2} \mathrm{O}$ & $0,05 \mathrm{~g}$ \\
$\left(\mathrm{NH}_{4}\right) 6 \mathrm{Mo}_{7} \mathrm{O}_{24} \cdot 4 \mathrm{H}_{2} \mathrm{O}$ & $0,05 \mathrm{~g}$ \\
$\mathrm{AlCl}_{3}$ & $0,05 \mathrm{~g}$ \\
$\mathrm{CoCl}_{2} \cdot 6 \mathrm{H}_{2} \mathrm{O}$ & $0,05 \mathrm{~g}$ \\
$\mathrm{NiCl}_{2} \cdot 6 \mathrm{H}_{2} \mathrm{O}$ & $0,092 \mathrm{~g}$ \\
$\mathrm{EDTA}$ & $0,5 \mathrm{~g}$ \\
$\mathrm{HCl} \mathrm{concentrado} \mathrm{Na}_{2} \mathrm{SeO}_{3} \cdot 5 \mathrm{H}_{2} \mathrm{O}$ & $1 \mathrm{~mL}$ \\
& $0,1 \mathrm{~g}$ \\
\hline
\end{tabular}

A solução estoque de vitaminas foi preparada por meio de dissolução dos itens em água deionizada (Tabela 4-5). A solução foi esterilizada por filtração em sistema Millipore em membrana de poro $0,22 \mu \mathrm{m}$, previamente esterilizado em autoclave a $121^{\circ} \mathrm{C}$ e $1 \mathrm{~atm}$ durante 20 minutos. Procedeu-se então a distribuição da solução em frascos de antibióticos $(30 \mathrm{~mL})$, sob fluxo de nitrogênio (100\%). Os frascos foram fechados com tampa de butila, lacrados e armazenados sob refrigeração.

\begin{tabular}{cc} 
Tabela 4-5 Solução de vitaminas utilizada nos ensaio em batela \\
\hline SOLUÇÃO E: VITAMINAS & $\begin{array}{c}\text { Quantidade }- \text { q.s.p. 1000 } \\
\mathrm{mL} \text { de água deionizada }\end{array}$ \\
\hline Biotina & $2 \mu \mathrm{g}$ \\
Ácido fólico & $2 \mu \mathrm{g}$ \\
Piridoxina & $10 \mu \mathrm{g}$ \\
Riboflavina & $5 \mu \mathrm{g}$ \\
Cloridrato de tiamina & $5 \mu \mathrm{g}$ \\
Vitamina B12 & $0,1 \mu \mathrm{g}$ \\
Ácido Nicotínico & $5 \mu \mathrm{g}$ \\
Ácido p-aminobenzóico & $5 \mu \mathrm{g}$ \\
Ácido lipóico & $5 \mu \mathrm{g}$ \\
Ácido DL-pantotênico & $5 \mu \mathrm{g}$ \\
\hline
\end{tabular}

A solução final do meio sintético foi preparada adicionando-se $10 \mathrm{~mL}$ da solução $\mathrm{A}, 2 \mathrm{~mL}$ da solução B, $1 \mathrm{~mL}$ da solução de rezasurina, $1 \mathrm{~mL}$ da solução de metais e $1 \mathrm{~mL}$ da solução de vitaminas em água deionizada anaeróbia (1.000 mL q.s.p.) (Tabela 4-6). 
Tabela 4-6 A solução final do meio sintético

\begin{tabular}{cc}
\hline SOLUÇÃo FINAL & $\begin{array}{c}\text { Quantidade - q.s.p. 1000 } \\
\mathrm{mL} \text { de água deionizada }\end{array}$ \\
\hline Solução A & $10 \mathrm{~mL}$ \\
Solução B & $2 \mathrm{~mL}$ \\
Solução C - Resazurina & $1 \mathrm{~mL}$ \\
Solução D - Metais e Selenito & $1 \mathrm{~mL}$ \\
Solução E- Vitaminas & $1 \mathrm{~mL}$ \\
\hline
\end{tabular}

Nos reatores em batelada foram adicionados no momento da inoculação solução de bicarbonato de sódio e sulfeto de sódio preparados sob condição anaeróbia como descritos por Vazoller (1995). As soluções foram esterelizadas por filtração em sistema Millipore em mebrana de 0,22 $\mu \mathrm{m}$.

\subsection{Co-substratos}

Para a alimentação dos reatores fermentativos-metanogênicos em batelada foram utilizados 457 mg.L $\mathrm{L}^{-1}$ de etanol e $680 \mathrm{mg} . \mathrm{L}^{-1}$ de formiato de sódio (Tabela 4-7). A variação de co-substratos e/ou de doadores de elétrons no processo de desalogenação do PCB sob condição fermentativa-metanogênica interfere diretamente nas taxas de remoção do cloro (NOLLET et al., 2005).

Nollet et al. (2005) confirmaram que entre diferentes fontes de carbono testadas, as taxas de remoção de cloro foram mais elevadas quando o etanol e formiato de sódio foram adicionados aos reatores em batelada. Outros pesquisadores (SCHÖLLHORN et al., 1997; WILDEMAN et al., 2003; GOMES et al., 2014) obtiveram alta eficiência de remoção com a utilização combinada destes cosubstratos na remoção de compostos xenobióticos, como PCB, tricloroetano (TCE) e dicloroetano (DCE).

Ademais, com o intuito de minimizar as disparidades de operação dos reatores em batelada e garantir a equidade experimental, os reatores operados sob condição desnitrificante foram alimentados com etanol (Tabela 4-7).

Baseando-se nos reatores metanogênicos, a somatória da DQO proveniente da adição de etanol (457 mg. $\mathrm{L}^{-1}$ ) e do formiato de sódio $\left(680 \mathrm{mg} . \mathrm{L}^{-1}\right.$ ) gerou DQO de $964 \mathrm{mg} \mathrm{O}_{2} \cdot \mathrm{L}^{-1}$. A partir destes resultados, os reatores desnitrificantes foram alimentados com $598 \mathrm{mg} \cdot \mathrm{L}^{-1}$ de etanol totalizando DQO de $984,63 \mathrm{mg} \mathrm{O} \cdot \mathrm{L}^{-1}$.

Tabela 4-7 Valores de DQO para as fontes de carbono utilizadas nos ensaios em batelada.

\begin{tabular}{ccccc} 
Fonte de carbono & $\begin{array}{c}\text { Concentração } \\
\left(\mathrm{mg} . \mathrm{L}^{-1}\right)\end{array}$ & DQO produzido $\left(\mathrm{mgO}_{2} \cdot \mathrm{L}^{-1}\right)^{1}$ & $\begin{array}{c}\text { Condição experimental } \\
\text { utilizada }\end{array}$ \\
\hline Formiato de sódio & 680 & $181,67 \pm 27,17$ & 964,0 & Metanogênica \\
\hline Etanol & 457 & $782,3 \pm 6,2$ & Desnitrificante \\
\hline Etanol & 598 & $984,3 \pm 3,4$ &
\end{tabular}

As soluções estoque de co-substratos (etanol e formiato de sódio) foram preparadas pela dissolução individual do reagente em água deionizada anaeróbia. Procedeu-se a distribuição das soluções em frascos de antibióticos $(30 \mathrm{~mL})$, sob fluxo $\mathrm{N}_{2}(100 \%)$. Os frascos foram fechados com 
tampa de butila, lacrados e esterilizados em autoclave a $121^{\circ} \mathrm{C}$ e $1 \mathrm{~atm}$, por 20 minutos. Os frascos foram armazenados a temperatura ambiente.

\subsection{Inóculo}

Em todos os reatores sob condição fermentativa-metanogênica foi utilizado inóculo proveniente de reator de manta de lodo e escoamento ascendente (UASB) usado no tratamento de resíduo de abatedouro de aves (Avícola Dakar, Tietê, SP), conhecido pelo alto potencial metanogênico (OLIVEIRA, 2010; DELFORNO, 2014). O lodo foi homogeneizado e desintegrado em liquidificador doméstico, e submetido a atmosfera de $\mathrm{N}_{2}(100 \%)$ durante 10 minutos, antes de sua utilização.

No Ensaio de Inibição Metanogênica e Ensaio de Remoção de PCB foi utilizado controle abiótico com essa mesma biomassa, todavia inativada por meio de tratamento térmico. Para tanto, a biomassa foi colocada em frascos adequados e transferida em autoclave a $121^{\circ} \mathrm{C}$ e $1 \mathrm{~atm}$, por 1 hora em três vezes consecutivas, de acordo com protocolo adaptado de Kaya; Imamoglu; Sanin (2013b).

Nos reatores operados sob condição desnitrificante, o inóculo foi proveniente de sistemas de lodos ativados usado no tratamento de esgoto sanitário da empresa Volkswagen (São Carlos, SP), com característica, tanto nitrificante, quanto desnitrificante (SOUZA, 2011). No Ensaio de Inibição Desnitrificante e Ensaio de Remoção de PCB foi utilizado controle abiótico com biomassa inativada por meio de tratamento térmico ( 3 vezes) a $121^{\circ} \mathrm{C}, 1$ atm por 1 hora, de acordo com metodologia descrita por Kaya; Imamoglu; Sanin (2013b) adaptada. Os ensaios sob condição anóxica foram realizados com biomassa em suspenção, ou seja, não foi adicionado material suporte nos reatores em batelada.

Como o lodo proveniente do reator de lodos ativados é muito diluído, foi necessária a realização de uma etapa para concentração do mesmo, antes de inocular nos reatores em batelada. Assim, $40 \mathrm{ml}$ do inóculo foi centrifugado a $9.000 \mathrm{rpm}$ por 15 minutos, a $15^{\circ} \mathrm{C}$. Após a centrifugação, o sobrenadante foi descartado, sendo adicionado mais $40 \mathrm{~mL}$ da biomassa e posterior centrifugação. A amostra foi centrifugada 5 vezes no total. Essa biomassa concentrada foi usada para inoculação dos reatores sob condição desnitrificante.

\subsection{Material suporte}

No Ensaio de Inibição Metanogênica foi utilizada espumas de poliuretano como material suporte nos reatores em batelada para induzir a adesão dos microrganismos. As espumas de poliuretano foram cortadas em cubos de $5 \mathrm{~cm}$ de aresta e lavadas com água destilada ( $300 \mathrm{~mL}, 3 \mathrm{x}$ ), em seguida acetona P. A. (300 mL, 3x) e por fim, com $n$-hexano grau UV para cromatografia liquida ( $300 \mathrm{~mL}, 3 \mathrm{x})$ para a remoção de contaminantes orgânicos da superfície (LAWRENCE; TOSINE, 1976; ADORNO, 2013; GOMES et al., 2014).

Com o intuito de facilitar a análise e extração do PCB dos reatores em batelada, no Ensaio de Remoção de PCB sob condição metanogênica, Ensaio Relação Carbono e Nitrogênio, Ensaio de Inibição Desnitrificante e Ensaio de Remoção de PCB sob condição desnitrificante não foram adicionadas espumas de poliuretano como material suporte, sendo a biomassa mantida em crescimento planctônico. 


\title{
4.6 Procedimentos Analíticos para acompanhamento dos experimentos laboratoriais
}

Análises de demanda química de oxigênio (DQO), pelo método espectrofotométrico, $\mathrm{pH}$ (potencial hidrogeniônico) e sólidos totais voláteis, pelo método gravimétrico, foram realizadas de acordo com APHA (2005).

Nitrato, nitrito e amônia foram analisados por meio de cromatografia iônica. A cromatografia iônica foi feita em cromatógrafo de íons Dionex ICS - 5000, equipado com supressora de ânions e detecção por condutividade. A coluna foi mantida a $35{ }^{\circ} \mathrm{C}$ e a fase móvel utilizada foi solução de carbonato $(4,5 \mathrm{mM})$ e bicarbonato de sódio $(0,8 \mathrm{mM})$ (SABATINI et al., 2014). O monitoramento dos reatores em batelada sob condição anóxica foi realizado por meio da quantificação do consumo de nitrato $\left(\mathrm{NO}_{3}{ }^{-}\right)$. A avaliação da desnitrificação foi realizada por meio da eficiência de remoção de formas nitrogenadas, $\mathrm{NO}_{\mathrm{x}}\left(\mathrm{NO}_{3}{ }^{-}\right.$e $\left.\mathrm{NO}_{2}^{-}\right)$.

Como a acumulação de nitrito nos sistemas desnitrificantes podem superestimar a desnitrificação (HER; HUANG, 1995), essa eficiência foi calculada a partir da concentração de $\mathrm{NO}_{3}{ }^{-}$ (nitrato) e $\mathrm{NO}_{2}^{-}$(nitrito) nos reatores de acordo com a Equação 4-1.

Equação 4-1

$$
\mathbf{E}_{\mathrm{D}}=\left(1-\frac{\left[\mathrm{NO}_{\mathrm{x}}^{-}\right] \text {final }}{\left[\mathrm{NO}_{\mathrm{x}}^{-}\right] \text {inicial }}\right) \times \mathbf{x 1 0 0}
$$

Sendo:

\author{
$\mathrm{E}_{\mathrm{D}}=$ eficiência de desnitrificação; \\ $\left[\mathrm{NO}_{\mathrm{x}}^{-}\right]$inicial $=$Concentração inicial de $\mathrm{NO}_{3}{ }^{-} \mathrm{e} \mathrm{NO}_{2}{ }^{-}\left(\mathrm{mg} \cdot \mathrm{L}^{-1}\right)$ \\ $\left[\mathrm{NO}_{\mathrm{x}}{ }^{-}\right]$final $=$Concentração final de $\mathrm{NO}_{3}^{-} \mathrm{e} \mathrm{NO}_{2}^{-}\left(\mathrm{mg} \cdot \mathrm{L}^{-1}\right)$.
}

Os ácidos orgânicos voláteis foram determinados por cromatografia gasosa, CG (ADORNO; HIRASAWA; VARESCHE, 2014) ou por cromatografia liquida de alta eficiência, CLAE (PENTEADO et al., 2013). Por meio da metodologia da cromatografia gasosa determinou-se Metanol, Etanol, Isobutanol, N-Butanol, Ácido Acético, Ácido Propiônico, Ácido Isobutírico, Ácido Butírico, Ácido Isovalérico, Ácido Valérico e Ácido Capróico. Por meio da cromatografia líquida de alta eficiência determinou-se os seguintes ácidos: Capróico, Valérico, Isovalérico, Butírico, Isobutírico, Propiônico, Acético, Fórmico, Lático, Succínico, Málico e Cítrico.

As análises de biogás foram realizadas em cromatógrafo gasoso (GC-2010 SHIMADZU) equipado com Detector de Condutividade Térmica (GC-TCD). Para tanto, foi retirado 0,5 $\mu \mathrm{L}$ do headspace dos reatores fermentativos-metanogênicos. A coluna utilizada foi Carboxen 1010 plot $30 \mathrm{~m}$ x 0,53 mm com Argônio como gás de arraste (ADORNO, 2014). O monitoramento dos reatores em batelada sob condição anaeróbia foi realizado por meio da quantificação da produção especifica de metano, em $\mu \mathrm{molCH}_{4} \cdot \mathrm{gSTV}^{-1}$. 


\subsubsection{Análises Cromatográficas do PCB}

A Hipótese 1 foi avaliada por meio do desenvolvimento e validação do método para determinação de seis congêneres de PCB por cromatografia gasosa (CG) com a utilização da técnica de microextração em fase sólida (SPME).

\section{Microextração em fase sólida}

A técnica de SPME foi utilizada como metodologia de extração e análise do PCB das amostras provenientes dos ensaios em batelada (Figura 4-2). A extração imersa no líquido (SPMEi) não foi

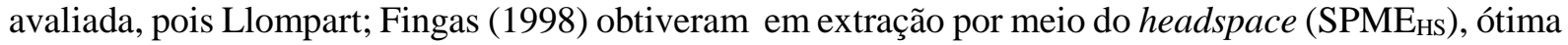
linearidade e sensibilidade, além de menor interferência dos componentes da matriz e vida útil da fibra mais prolongada.

O método foi desenvolvido em cromatógrafo gasoso Hewlett-Packard, 5890 series II equipado com detector de captura de elétrons (GC-ECD) - coluna capilar Elite - 5 Perkin Elmer (30 m x 0,32 mm $\mathrm{x} 0,25 \mu \mathrm{m}$ ). $\mathrm{O}$ gás de arraste foi o hidrogênio e o gás auxiliar o nitrogênio, modo splitless (sem divisão do volume injetado), 6 psi de pressão na cabeça da coluna, temperatura do detector de $300^{\circ} \mathrm{C}$ e do forno de $160{ }^{\circ} \mathrm{C}$, até $200^{\circ} \mathrm{C}$, a $20^{\circ} \mathrm{C} \cdot \mathrm{min}^{-1}$, até $270^{\circ}(1 \mathrm{~min})$, a $30^{\circ} \mathrm{C} \cdot \mathrm{min}^{-1}$, até $290^{\circ} \mathrm{C}(10 \mathrm{~min})$, a $30^{\circ} \mathrm{C} \cdot \mathrm{min}^{-1}$, totalizando 16 minutos de corrida. 
(a)

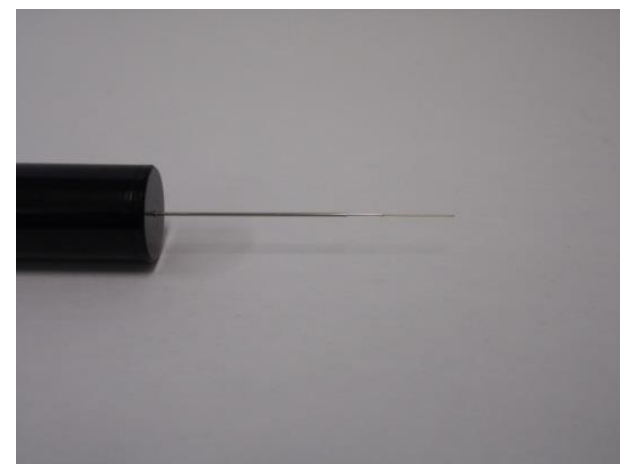

(b)

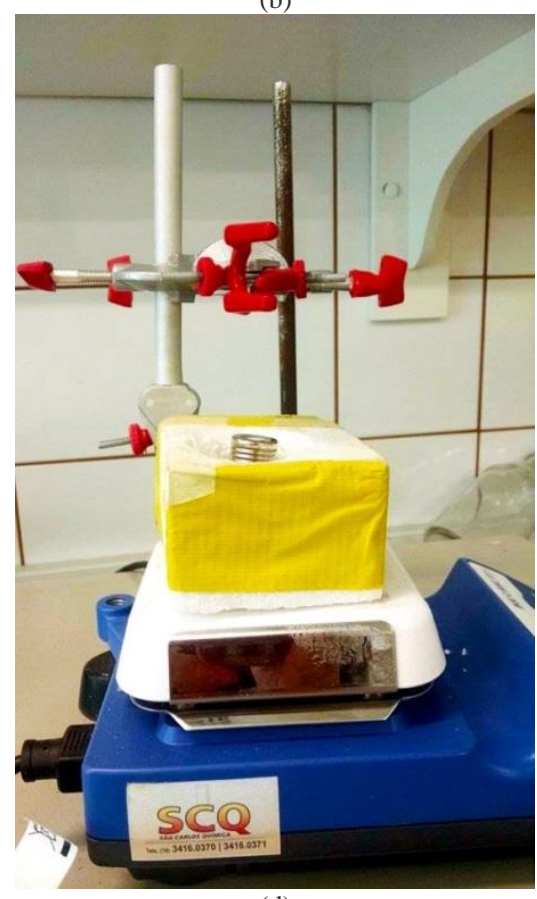

(d)

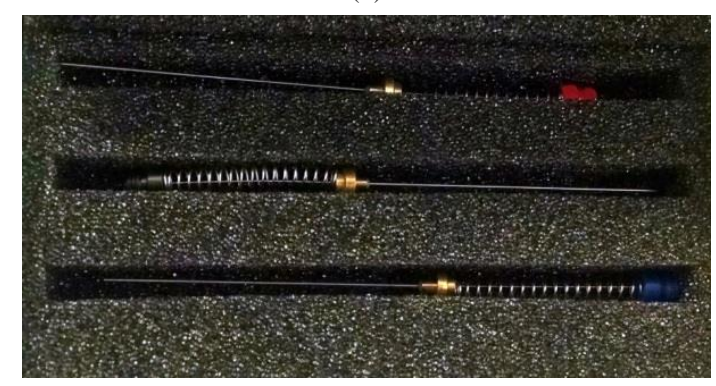

(f)

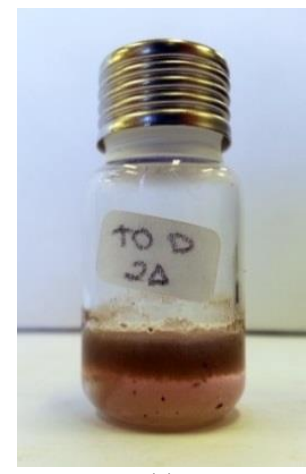

(c)

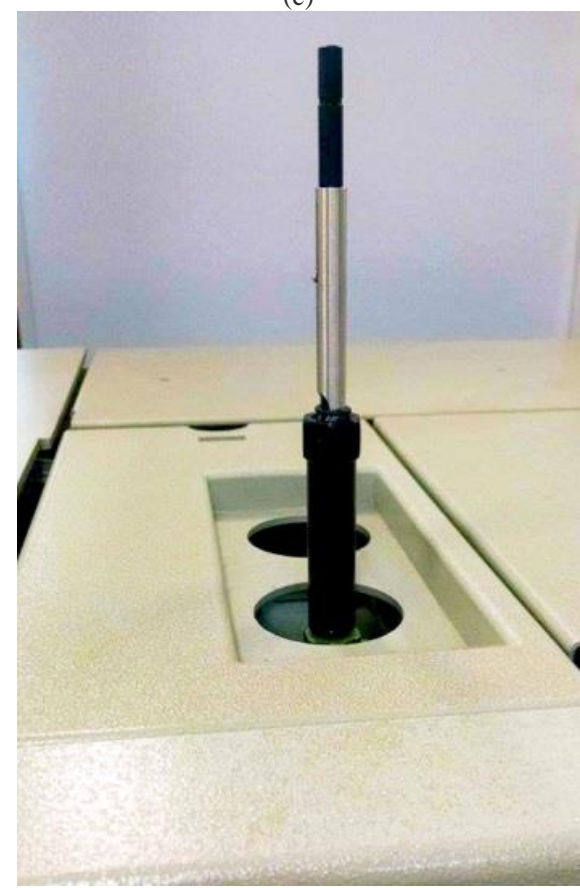

(e)

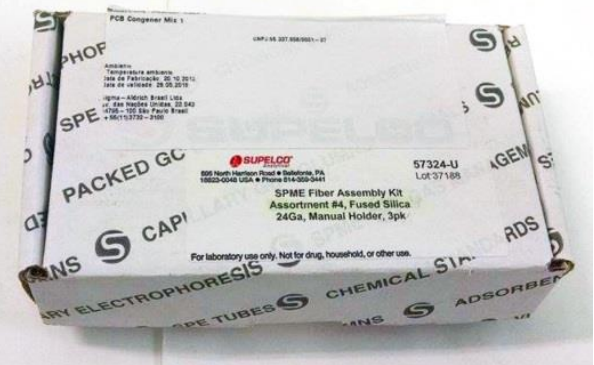

(g)

Figura 4-2 Amostrador e fibras utilizadas para a extração do PCB por meio da técnica de SPME. (a) amostrador manual; (b) Fibra exposta do amostrador; (c) Frasco para amostrador automático por headspace; (d) aparato para extração do PCB; (e) amostrador acoplado ao Cromatógrafo gasoso; (f) Fibras testadas, PDMS/DVB (azul), PDMS (vermelha) e carboxen/PDMS (preta); (g) Caixa de fibras testadas. 
Realizaram-se vários testes para determinar as melhores condições cromatográficas a partir da mistura de solução de seis congêneres de PCB. As seguintes fibras foram avaliadas: 100 $\mu \mathrm{m}$ PDMS, $65 \mu \mathrm{m}$ PDMS/DVB e $75 \mu \mathrm{m}$ carboxen/PDMS (Sigma-Aldrich ${ }^{\circledR}$ ) em diferentes tempos de extração, temperatura, presença de $\mathrm{NaCl}$ e volume da amostra (Tabela 4-8).

Para testar as diferentes condições prepararam-se padrão da solução de PCB de 0,09 mg.L $\mathrm{L}^{-1}$, 1,5 mg.L. ${ }^{-1}$ e 3,0 mg.L $L^{-1}$ em água e em meio sintético. Em frasco de $10 \mathrm{~mL}$ de amostrador automático de headspace, com tampa de alumínio e teflon (Figura 4-2[c]) colocou-se de 2,0 mL a 3,0 mL de amostra e uma barra magnética para manter a agitação sobre um agitador magnético (marca Ika ${ }^{\circledR}$, modelo CMag MS 4). Após o condicionamento da fibra no cromatógrafo, ela foi exposta a amostra no aparato experimental, e decorrido o tempo de extração, era injetada no cromatógrafo para a fase de dessorção e análise cromatográfica.

Tabela 4-8 Condições avaliadas na escolha da melhor condição de extração e análise do PCB das amostras dos reatores em batelada.

\begin{tabular}{|c|c|c|c|c|c|c|c|c|}
\hline Amostra & Fibra de SMPE & $\begin{array}{l}\text { Concentração } \\
\text { PCB }\left(\mathrm{mg} \cdot \mathrm{L}^{-1}\right)\end{array}$ & $\begin{array}{l}\text { Volume } \\
\text { amostra } \\
(\mathrm{mL})\end{array}$ & $\begin{array}{l}\mathrm{NaCl} \\
(\mathrm{g})\end{array}$ & $\begin{array}{l}\text { Temp. } \\
\text { Extração } \\
\left({ }^{\circ} \mathrm{C}\right)\end{array}$ & $\begin{array}{l}\text { Temp. } \\
\text { dessorção } \\
\left({ }^{\circ} \mathrm{C}\right)\end{array}$ & $\begin{array}{l}\text { Tempo } \\
\text { extracãão } \\
\text { (min) }\end{array}$ & $\begin{array}{l}\text { Padrão Interno - } \\
\text { Octacloronaftaleno } \\
\left(\mathrm{mg.L} \mathrm{L}^{-1}\right)\end{array}$ \\
\hline & PDMS & 0 & & & & & & 0 \\
\hline Água & $(100 \mu \mathrm{m})$ & & $2,0 \mathrm{~mL}$ & 0 & & 210 & 5 & 0,5 \\
\hline $\begin{array}{c}\text { PCB + } \\
\text { Meio }\end{array}$ & $\begin{array}{l}\text { PDMS/DVB } \\
\quad(65 \mu \mathrm{m})\end{array}$ & $\begin{array}{r}0,09 \\
1,5\end{array}$ & $2,5 \mathrm{~mL}$ & 0,5 & 22 & 250 & 15 & 0,8 \\
\hline Água & $\begin{array}{l}\text { Carboxen/PDM } \\
\text { S }(75 \mu \mathrm{m})\end{array}$ & 3,0 & $3,0 \mathrm{~mL}$ & 1,0 & & 280 & 30 & $\begin{array}{l}1,5 \\
3,0\end{array}$ \\
\hline
\end{tabular}

A técnica de extração foi avaliada e aperfeiçoada comparando-se a eficiência da extração de acordo com a reprodutibilidade do teste e o padrão de otimização. A reprodutibilidade foi avaliada por meio do coeficiente de variação da triplicata e perfil dos picos cromatográficos em cada condição. Em geral em cromatografia gasosa picos mais estreitos e bem definidos são relacionados com melhor eficiência na extração e análise do analito.

O coeficiente de variação é uma medida de dispersão relativa empregada para estimar a precisão de experimentos e representa o desvio-padrão expresso como porcentagem da média, no caso deste estudo, das triplicatas (RIBANI et al., 2004). Os erros resultantes de estimativas de altura de pico no cromatograma são refletidas nos coeficientes de variação, e quanto menor o coeficiente de variação, menor é a variação entre as replicatas e, consequentemente, maior é sua reprodutibilidade. O padrão de otimização foi avaliado por meio de gráficos de área cromatográfica versus condição variante, onde a áreas maiores representam otimização da metodologia de extração do PCB.

Essas diferentes condições de extração foram testadas objetivando-se a seleção da condição que melhor expressasse o conteúdo de PCB total nas amostras, maior eficiência e reprodutibilidade dos resultados. Sob tais condições foi conduzido a preparação da curva de calibração conjuntamente com a validação do método cromatográfico. 


\section{Elaboração das curvas de calibração e validação}

\section{Preparo das soluções-estoques de PCB}

As diferentes concentrações da solução-estoque do PCB para a curva foi preparada a partir da solução Congener Mix 1 (10 mg.L. - $^{-1}$ ) diluída em meio sintético (ANGELIDAKI et al., 2009) (Tabela 4-9). Para cada concentração foi preparada solução-estoque em triplicata, que foi armazenada sob refrigeração $\left(4^{\circ} \mathrm{C}\right)$ até seu posterior uso.

Tabela 4-9 Preparação da solução-estoque para utilização na curva analítica.

\begin{tabular}{|c|c|c|c|c|}
\hline Ponto da Curva & $\begin{array}{c}\text { Concentração Solução } \\
\left(\mathrm{mg} \cdot \mathrm{L}^{-1}\right)\end{array}$ & $\begin{array}{c}\text { Volume de Congener } \\
\text { Mix } 1(\mu \mathrm{L})\end{array}$ & $\begin{array}{l}\text { Volume do meio de } \\
\text { cultura }(\mu \mathrm{L})\end{array}$ & $\begin{array}{l}\text { Volume total da } \\
\text { Solução }(\mu \mathrm{L})\end{array}$ \\
\hline 1 & 0,1 & 50 & 4995 & \multirow{6}{*}{5000} \\
\hline 2 & 0,2 & 100 & 4900 & \\
\hline 3 & 0,3 & 150 & 4850 & \\
\hline 4 & 0,5 & 250 & 4750 & \\
\hline 5 & 1,0 & 500 & 4500 & \\
\hline 6 & 2,0 & 1000 & 4000 & \\
\hline
\end{tabular}

\section{Curva de calibração}

Para realizar as curvas de calibração foram utilizados os parâmetros descritos na Tabela 4-10. Alíquotas de 2,0 mL de cada solução-estoque em triplicata foram amostrados no frasco de análise, adicionado de $\mathrm{NaCl}$ e barra magnética para agitação. A fibra então foi exposta ao headspace da amostra, e terminado o tempo de extração, foi injetado no cromatógrafo para fase de dessorção concomitante com a análise cromatográfica. O método de análise de PCB por meio da técnica de SPME foi validado pela determinação de sua linearidade, precisão, recuperação relativa e limites de detecção (LD) e quantificação (LQ) de acordo com Ribani et al. (2004).

Tabela 4-10 Parâmetros estabelecidos para análise da concentração de PCB pela técnica de SPME.

\begin{tabular}{ccccccc} 
Fibra de SMPE & $\begin{array}{c}\text { Volume de } \\
\text { amostra } \\
(\mathrm{mL})\end{array}$ & $\begin{array}{c}\mathrm{NaCl} \\
(\mathrm{g})\end{array}$ & $\begin{array}{c}\text { Tempo de extração } \\
(\mathrm{min})\end{array}$ & $\begin{array}{c}\text { Temperatura } \\
\text { Extração } \\
\left({ }^{\circ} \mathrm{C}\right)\end{array}$ & $\begin{array}{c}\text { Tempo } \\
\text { Dessorção } \\
(\mathrm{min})\end{array}$ & $\begin{array}{c}\text { Temperatura } \\
\text { Dessorção } \\
\left({ }^{\circ} \mathrm{C}\right)\end{array}$ \\
\hline $\begin{array}{c}\text { PDMS/DVB } \\
(65 \mu \mathrm{m})\end{array}$ & 2,0 & 0,5 & 15 & 22 & 16 & 250 \\
\hline
\end{tabular}

\section{Linearidade e faixa de aplicação}

A curva analítica foi expressa pela equação de reta a partir dos picos obtidos no cromatograma das concentrações em cada ponto da curva. A relação matemática entre o sinal e a concentração do analito corresponde a linearidade do método e, no caso deste trabalho foi calculado para cada congênere de PCB.

O LD representa a menor quantidade do analito (concentração) que o método é capaz de detectar e foi calculado por parâmetros da curva analítica como se segue (RIBANI et al., 2004): 
Equação 4-2

$$
L D=3,3 x(s / s)
$$

Sendo:

$\mathrm{s}=\mathrm{a}$ estimativa do desvio padrão do coeficiente linear da curva analítica,

S = a inclinação ou coeficiente angular da curva analítica.

O LQ refere-se à menor concentração do analito que pode ser quantificada a partir de um método experimental. Quanto menor o LQ, menor a precisão do método. Foi usado os mesmos critérios considerados para LD, com uma relação 10:1 referente à relação sinal/ruído entre o desvio padrão da resposta analítica e a inclinação da curva analítica (Equação 4-3).

Equação 4-3

$$
L Q=10 x(s / s)
$$

Sendo:

$\mathrm{s}=\mathrm{a}$ estimativa do desvio padrão do coeficiente linear da curva analítica $\mathrm{e}$

$S=$ a inclinação ou coeficiente angular da curva analítica.

Tanto, para LD, quanto para LQ é mais conveniente usar o método que considera os parâmetros da curva analítica, por ser mais confiável estatisticamente, uma vez que a relação sinal/ruído pode ser afetada pelo tamanho dos picos, podendo, portanto, ser subjetiva (RIBANI et al., 2004).

\section{Repetitividade}

Repetitividade de um método é o grau de variância, ou coeficiente de variação entre resultados de testes independentes obtidos a partir de material de estudo sob condições estipuladas. Análises de precisão deve incluir análises intra-dia (repetibilidade) e inter-dia. A precisão intra-dia é a repetição da mesma amostra no mesmo dia. Já a precisão inter-dia, é a análise de pontos da curva injetados em dias diferentes.

Para a realização da precisão intra-dia, foram analisados em triplicata os pontos 2,4 e 5 da curva, e em quintuplicata os pontos 1, 3 e 6. Para a avaliação da precisão inter-dia, foi analisado em triplicata o ponto 3 , em dia distinto da primeira análise.

\section{Exatidão}

Um dos processos mais utilizados para avaliar a exatidão de um método é a análise da recuperação relativa (RIBANI et al., 2004). A recuperação relativa foi estimada pela análise de amostras de água fortificadas com quantidades conhecidas do PCB semelhantes aos pontos 1,2 e 3 da curva. A recuperação foi calculada como a porcentagem entre amostras com água e dos pontos da curva, por meio da equação: 


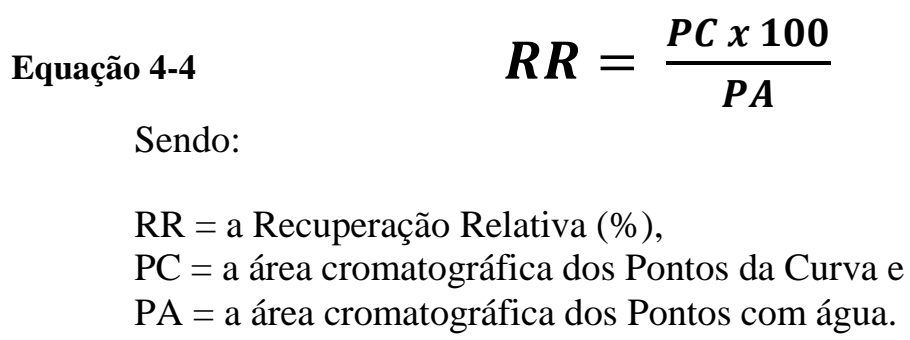

Sendo:

$\mathrm{RR}=$ a Recuperação Relativa (\%),

$\mathrm{PC}=\mathrm{a}$ área cromatográfica dos Pontos da Curva e

$\mathrm{PA}=\mathrm{a}$ área cromatográfica dos Pontos com água.

\section{Determinação da concentração de PCB nos reatores em batelada}

A concentração do PCB do Ensaio de Remoção de PCB foi acompanhada por meio de análise de amostras líquidas ( $2 \mathrm{~mL}$ ), que foram retiradas no início (T0), no meio, por volta de 80 dias (T1) e final, por volta de 100 dias (T2) da operação dos reatores em batelada.

Foi utilizado o método de adição do padrão, ou Standard addiction, para quantificar o PCB proveniente de amostras dos reatores a fim de minimizar o efeito de matriz nas amostras ( RIBANI et al., 2004; OUYANG; PAWLISZYN, 2008). O método de adição de padrão consiste em realização da curva analítica com adição de quantidades conhecidas da substancia de interesse, e a extrapolação desta curva, o ponto onde a reta corta o eixo das ordenadas, a concentração real da substância interesse (RIBANI et al., 2004). Neste sentido, de quatro a seis pontos de adição de padrão foram avaliados para cada congênere, por meio da adição sucessiva de PCB (Tabela 4-11).

Tabela 4-11 Relação de pontos e concentrações adicionadas de PCB no método de Adição de Padrão.

\begin{tabular}{ccccccc} 
Ponto & 1 & 2 & 3 & 4 & 5 & 6 \\
\hline $\begin{array}{c}\text { Concentração } \\
\text { adicionada (mg.L }\end{array}$ & 0 & 0,03 & 1,0 & 1,5 & 2,0 & 3,0 \\
\hline
\end{tabular}

A concentração foi calculada a partir da intersecção e inclinação do gráfico de adição de padrão de acordo com a Equação 4-5, de acordo com Miller; Miller (1993).

Equação 4-5

$$
C_{P C B}=A b s(-b / a)
$$

Sendo,

$\mathrm{C}_{\mathrm{PCB}}=$ Concentração do PCB nos reatores,

-b = intercepção do gráfico no eixo y e

$\mathrm{a}=$ inclinação do gráfico.

\subsection{Caracterização da diversidade microbiana}

\subsubsection{Exames Microscópios}

As morfologias dos microrganismos foram avaliadas por meio de exames microscópios de contraste de fase e fluorescência. Os exames microscópios foram realizados no início e final da operação dos reatores do Ensaio de Remoção de PCB sob condição fermentativa-metanogênica (MT0 e MT2) e desnitrificante (DT0 e DT2). Para avaliar a morfologia celular foi utilizado Microscópio Olympus BX- 
60, acoplado a câmera com captura de imagens (Evolution QE, Media Cybernetics Inc., USA) e software Image Pro-Plus 4.5.

Para tanto, foram retiradas amostras em diferentes tempo de operação e condição dos reatores em batelada, adicionada em uma lâmina previamente limpa com detergente e álcool. A alíquota da amostra foi colocada sobre fina camada de ágar (2\%) e recoberta com lamínula. Em seguida a amostra foi analisada em microscópio.

\subsubsection{Análises Filogenéticas}

\section{I) Estocagem de amostra e extração de DNA}

Para análise de biologia molecular foram utilizadas amostras de todas as etapas de operação dos reatores em batelada. As amostras com material suporte, do Ensaio de Inibição Metanogênica, foram provenientes do biofilme aderido à espuma, e as amostras dos reatores sem material suporte, do Ensaio Relação Carbono e Nitrogênio, do Ensaio de Inibição Desnitrificante e do Ensaio de Remoção de PCB, foram provenientes da biomassa suspensa. As amostras de todos os ensaios foram avaliadas pela técnica de PCR/DGGE e amostras do Ensaio de Remoção de PCB foram analisadas por meio de sequenciamento massivo.

Previamente a extração de DNA, as amostras foram lavadas (3x) com tampão PBS (1X) e centrifugadas a $4^{\circ} \mathrm{C}$ com rotação de $3.000 \mathrm{rpm}$ durante 10 minutos. Após a lavagem os pellets foram armazenados a $-20^{\circ} \mathrm{C}$ até a extração de DNA.

A extração de DNA genômico das amostras para as análises da eletroforese em gel de gradiente desnaturante (DGGE) foram realizadas pelo método direto utilizando glass beads e mistura de fenol, clorofórmio e tampão (1:1:1) seguindo o procedimento de Griffiths et al. (2000), com algumas modificações em virtude do material biológico em estudo, descrito na Tabela 4-12.

Tabela 4-12 A extração de DNA genômico das amostras seguindo o procedimento de Griffiths et al. (2000) modificado.

\begin{tabular}{|c|c|c|c|c|c|c|}
\hline Amostra & Glass beads & PBS & $\begin{array}{c}\text { Fenol tamponado } \\
\text { com Tris }\end{array}$ & Clorofórmio & Agitação & Centrifugação \\
\hline $0,5 \mathrm{~g}$ & 0,5 & $1 \mathrm{~mL}$ & $1 \mathrm{~mL}$ & $1 \mathrm{~mL}$ & $50 "$ & $\begin{array}{c}10 \mathrm{~min} / 6.000 \\
\mathrm{rpm} / 4^{\circ} \mathrm{C}\end{array}$ \\
\hline $1 \mathrm{~mL}$ & - & - & $1 \mathrm{~mL}$ & - & $50 "$ & $\begin{array}{c}10 \mathrm{~min} / 6.000 \\
\mathrm{rpm} / 4^{\circ} \mathrm{C}\end{array}$ \\
\hline $800 \mu \mathrm{L}$ & - & - & - & $800 \mu \mathrm{L}$ & $50 "$ & $\begin{array}{c}10 \mathrm{~min} / 6.000 \\
\mathrm{rpm} / 4^{\circ} \mathrm{C}\end{array}$ \\
\hline $600 \mu \mathrm{L}$ & - & - & - & $600 \mu \mathrm{L}$ & $50 "$ & $\begin{array}{c}10 \mathrm{~min} / 6.000 \\
\mathrm{rpm} / 4^{\circ} \mathrm{C}\end{array}$ \\
\hline
\end{tabular}

Aproximadamente $400 \mu \mathrm{L}$ do sobrenadante foi retirado e transferido para outro tubo e então o DNA foi desidratado e precipitado em $1 \mathrm{~mL}$ de etanol $95 \%\left(4^{\circ} \mathrm{C}\right)$, depois em $0,5 \mathrm{~mL}$ de etanol $70 \%$ $\left(4^{\circ} \mathrm{C}\right)$. Após cada adição de etanol, a amostra era homogeneizada e centrifugada por 10 minutos a 10.000 $\mathrm{rpm} \mathrm{a} 4^{\circ} \mathrm{C}$ e deixado para secagem natural por 24 horas. Todo o material foi eluído em $100 \mu \mathrm{L}$ de tampão TE e armazenado a $-20^{\circ} \mathrm{C}$.

Para verificar a integridade e a concentração do DNA foi realizada eletroforese em gel de agarose a $0,8 \%(\mathrm{~m} / \mathrm{v})$, utilizando $5 \mu \mathrm{L}$ do extrato de ácido nucleico homogeinizado em $1 \mu \mathrm{L}$ de loading dye e como padrão foi utilizado $2 \mu \mathrm{L}$ do High DNA Mass Ladder Invitrogen. As condições da corrida 
da eletroforese foram $75 \mathrm{~V}\left(6 \mathrm{~V} . \mathrm{cm}^{-1}\right)$ constante por 30 minutos. Após a corrida o gel foi transferido para a câmara de trans-iluminador UV (Stratagene- Eagle Eye II) para a observação das bandas do gel.

Algumas amostras foram submetidas a purificação do DNA, por apresentarem bandas fracas ou com impurezas. A purificação foi realizada com o Kit Illustra GFX PCR DNA e Gel Band Purification (GE Healthcare) seguindo seu protocolo.

\section{II) $P C R / D G G E$}

Para a análise da diversidade microbiana das amostras dos reatores em batelada dos Ensaios de Inibição Metanogênica, Relação Carbono e Nitrogênio, Inibição Desnitrificante e Remoção de PCB foi utilizada a técnica PCR/DGGE, tanto para o Domínio Bacteria, quanto para o Archaea.

A coleta das amostras dos reatores em batelada dos ensaios Inibição Metanogênica, Relação Carbono e Nitrogênio e Inibição Desnitrificante ocorreu após o término da operação dos reatores (por volta de 30 dias). A coleta das amostras dos reatores do Ensaio Remoção de PCB foi realizada no início (T0, representa o inóculo), no meio (T1, por volta de 80 dias) e no final da operação (T2, por volta de 100 dias).

Para iniciadores filogenéticos do Domínio Bacteria (968FGC e 1401R) (Tabela 4-13) foram utilizadas as condições de amplificação descritas por Nübel et al. (1996) cuja programação do termociclador (Eppendorf AG - 22331 Hamburg) está apresentada na Tabela 4-14.

Tabela 4-13 Iniciadores para amplificação da região do RNAr 16S para o Domínio Bacteria.

\begin{tabular}{cc} 
Primers & Sequencias (5’-3') \\
\hline 968FGC & '- CGC CCG GGG CGC GCC CCG GGC GGG GCG GGG GCA GGC GGG GAA CGC GAA GAA CCT TAC-3' \\
\hline $1401 \mathrm{R}$ & 5'-CGG TGT GTA CAA GAC CC-3' \\
\hline & Fonte: Nübel et al. (1996)
\end{tabular}

Tabela 4-14 Programação do termociclador para amplificação do RNAr 16S para o Domínio Bacteria.

\begin{tabular}{|c|c|c|c|c|c|c|c|c|}
\hline Desnaturação inicial & Desnaturação & Anelamento & Extensão & Desnaturação & Anelamento & Extensão & Extensão final & Resfriamento \\
\hline $95^{\circ} \mathrm{C}$ & $94^{\circ} \mathrm{C}$ & $56^{\circ} \mathrm{C}$ & $72^{\circ} \mathrm{C}$ & $94^{\circ} \mathrm{C}$ & $55^{\circ} \mathrm{C}$ & $72^{\circ} \mathrm{C}$ & $72^{\circ} \mathrm{C}$ & \multirow{3}{*}{$4^{\circ} \mathrm{C}$} \\
\hline \multirow[t]{2}{*}{ 05:00 } & 00:30 & 00:40 & 01:00 & $00: 45$ & $00: 45$ & 01:00 & \multirow[t]{2}{*}{ 07:00 } & \\
\hline & & 10 ciclos & & & 25 ciclos & & & \\
\hline
\end{tabular}

Para o Domínio Archaea foram utilizados os iniciadores 1100FGC e 1400R (Tabela 4-15) (KUDO et al., 1997) cuja programação do termociclador (Perkin Elmer GeneAmp PCR System 2400) está apresentada na Tabela 4-16.

Tabela 4-15 Iniciadores para amplificação da região RNAr 16S para o Domínio Bacteria.

\begin{tabular}{|c|c|}
\hline Primers & Sequencias $\left(5^{\prime}-3^{\prime}\right)$ \\
\hline $1100 \mathrm{FGC}$ & $\begin{array}{l}\text { '’-CGC CCG CCG CGC GCG GCG GGC GGG GCG GGG GCA GGC GGG AAC CGT CGA TCA GGY AAC GAG } \\
\text { CGA-3' }\end{array}$ \\
\hline $1400 \mathrm{R}$ & 5'-CGG CGA ATT CGT GCA AGG AGC AGG GAC-3' \\
\hline
\end{tabular}


Tabela 4-16 Programação do termociclador para amplificação do RNAr 16S para o Domínio Archaea.

\begin{tabular}{c|ccc|c|c} 
Desnaturação inicial & Desnaturação & Anelamento & Extensão & Extensão final & Resfriamento \\
\hline $955^{\circ} \mathrm{C}$ & $94^{\circ} \mathrm{C}$ & $55^{\circ} \mathrm{C}$ & $72^{\circ} \mathrm{C}$ & $72^{\circ} \mathrm{C}$ & \multirow{2}{*}{$4^{\circ} \mathrm{C}$} \\
\hline \multirow{2}{*}{$05: 00$} & $01: 00$ & $01: 00$ & $01: 00$ & $07: 00$ & \\
\cline { 2 - 4 } & & 35 ciclos & & \\
\hline
\end{tabular}

O produto da PCR foi verificado por meio de eletroforese em gel de agarose a 1,2\%, utilizando $5 \mu \mathrm{L}$ do produto homogeneizado com $1 \mu \mathrm{L}$ de loading buffer e $2 \mu \mathrm{L}$ do padrão Low DNA Mass Ladder Invitrogen. As condições de corrida da eletroforese foram de $75 \mathrm{~V}\left(6 \mathrm{~V}^{-\mathrm{cm}^{-1}}\right)$ constante por 1 hora. Na Tabela 4-17 estão detalhados os reagentes e concentrações utilizadas para reação em cadeia da polimerase (PCR).

Tabela 4-17 Soluções para amplificação usando iniciadores 968FGC e 1401R e 1100FGC e 1400R.

\begin{tabular}{ccc} 
Reagentes & Concentração & 1 amostra $(\mu \mathrm{L})$ \\
\hline H2O ultrapurificada & - & 3,5 \\
Tampão PCR Invitrogen ${ }^{\circ}$ & $10 \mathrm{X}$ & 5,0 \\
$\mathrm{MgCl}_{2}$ & $50 \mathrm{mM}$ & 1,5 \\
dNTP (cada base nitrogenada) & $2 \mathrm{mM}$ & 5,0 \\
Primer Foward & $100 \mathrm{pmol} . \mu \mathrm{L}^{-1}$ & 0,5 \\
Primer Reverse & $100 \mathrm{pmol} . \mu \mathrm{L}^{-1}$ & 0,5 \\
Taq DNA Polimerase Invitroge ${ }^{1}$ & $5 \mathrm{U} \cdot \mu \mathrm{L}^{-1}$ & 0,5 \\
Amostra & $100 \mathrm{ng}$ & $2,0-3,0$ \\
\hline Total & - & $\sim 20$
\end{tabular}

O produto da PCR, com GC clamp, foi utilizado para o DGGE e o preparo das placas, tanto para o Domínio Archaea, quanto para o Domínio Bacteria foi usado gradiente de 45\% e 65\% (MUYZER; WAAL; UITIERLINDEN, 1993). As soluções para a eletroforese em gel com gradiente desnaturante (DGGE) foram preparadas em gel acrilamida (40\%), solução TAE 50X, formamida e uréia. Para as placas do gel foram utilizados $14 \mathrm{~mL}$ do gel na concentração almejada, $100 \mu \mathrm{L}$ de APS $10 \%$ (persulfato de amônia) e $10 \mu \mathrm{L}$ de Temed (tetrametiletilenodiamina).

As placas solidificadas do gel foram transferidas para a cuba eletroforética contendo $140 \mathrm{~mL}$ de TAE 1X. As amostras foram aplicadas nos poços do gel $(24 \mu \mathrm{L}$ de amostra e $6 \mu \mathrm{L}$ de corante para DGGE) e permaneceram na cuba a $75 \mathrm{~V}\left(6 \mathrm{~V} \cdot \mathrm{cm}^{-1}\right)$ a $65^{\circ} \mathrm{C}$ por 16 horas. Transcorrido o tempo de corrida, os géis foram transferidos para uma bandeja com água destilada e brometo de etídio por 15 minutos e então, foi observada em fotodocumentador Eagle Eye TM III (Stratagene), sob exposição em comprimento de onda de $254 \mathrm{~nm}$, acoplada a computador com o programa Eagle Sight para armazenamento das imagens. As imagens foram analisadas por meio do Bionumerics versão 2.5 .

\section{III) Sequenciamento Massivo}

O sequenciamento massivo do gene RNAr 16S via plataforma MiSeq da Illumina® foi usado para caracterização filogenética da biomassa dos reatores fermentativo-metanogênico e desnitrificante do Ensaio de Remoção de PCB, no tempo inicial e final (Figura 4-3). O sequenciamento foi realizado na Fundação De Estudos Agrários Luiz De Queiroz (FEALQ) com sede em Piracicaba, SP. Para tanto, foram enviadas amostras de DNA genônico purificado (5 a $\left.10 \mathrm{ng} . \mu \mathrm{L}^{-1}\right)$, o qual foi quantificado em espectrofotômetro Nanodrop ${ }^{\circledR}$ 2000. A integridade do DNA extraído foi verificada por eletroforese em gel de agarose $(0,8 \%$ em TAE $1 \mathrm{X})$. 


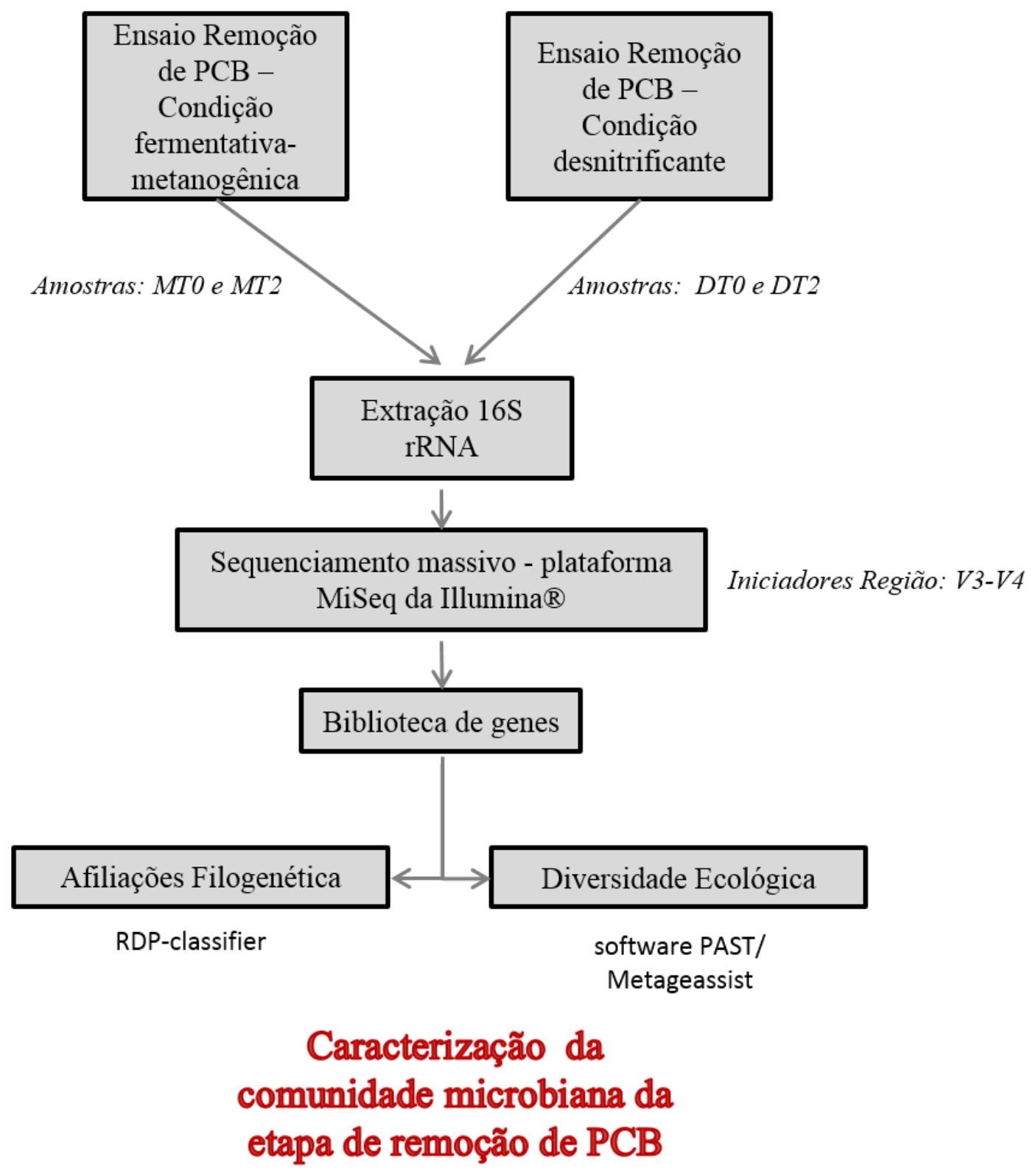

Figura 4-3 Fluxograma da etapa de sequenciamento massivo das amostras.

A região hipervariável V3-V4 do gene RNAr 16S (KLINDWORTH et al., 2013) foi amplificada utilizando os iniciadores universais para procariotas CCTACGGGNGGCWGCAG 16S (S-D-Bact0341-b-S-17) e GACTACHVGGGTATCTAATCC (S-D-Bact-0785-a-A-21) para o Domínio Bacteria e Archaea (TAKAHASHI et al., 2014), com base nos resultados de alinhamento. A deteç̧ão simultânea de bactérias e arqueias em amostras ambientais é interessante em termos de custo, contemplando análise da comunidade procariótica (TAKAHASHI et al., 2014).

A etapa de obtenção dos dados brutos foi feita pelo software Casava 1.8.2, fornecido pela Illumina, que faz o base call dos dados brutos e os transforma em leituras no formato fastq acompanhados dos scores de qualidade phred. As leituras foram visualizadas utilizando o programa FastQC (www.bioinformatics.bbsrc.ac.uk/projects/). 
A filtragem das leituras de baixa qualidade, sequências de adaptadores e vetores foi realizada pelo programa Seqyclean (https://bitbucket.org/izhbannikov/seqyclean), utilizando qualidade mínima de 24 QScore. As bases de dados de contaminantes usada foi a Univec (http://www.ncbi.nlm.nih.gov/VecScreen/UniVec.html). Após filtragem, sequências com tamanho inferior a $65 \mathrm{pb}$ foram removidas.

Para a análise de metagenômica foi utilizada a base de dados RDP (COLE et al., 2014) para Archaea e Bacteria. O pipeline usado foi o do pacote QIIME v 1.9 (CAPORASO et al., 2010) para a concatenação dos reads paired-end, filtragem, procura e identificação de UTOs (Unidade Taxonômica Operacional), análises de rarefação, alfa e beta diversidade.

As UTOs (Unidade Taxonômica Operacional) foram definidas por meio do programa QIIME v1.9. As sequencias brutas foram filtradas de acordo com as instruções do tutorial MiSeq, com adaptações. A distância genética de 3\% foi determinada para agrupar as sequencias em UTOs, porcentagem sugerida por Edgar (2010) para classificar um microrganismo em nível de espécie. RDPII Classifier foi a base de dados utilizada como referência para inferir as afiliações filogenéticas (WANG et al., 2007). A cobertura foi calculada de acordo com a Equação 4-6 (PENG et al., 2012):

\section{Equação 4-6}

$$
C=1-[(n-1 / N) x 100]
$$

Sendo:

$\mathrm{C}=$ cobertura calculada,

$\mathrm{n}=$ número de UTOs únicas (singletons) e

$\mathrm{N}=$ total de sequências encontradas.

\section{IV) Análises das sequencias}

As sequencias obtidas na plataforma MiSeq foram tratadas e analisadas utilizando as ferramentas do programa QIIME v1.9 (CAPORASO et al., 2010), aquelas do site RDP's Ribosomal Database Project (WANG et al., 2007) e também pelo Metagenassist (http://www.metagenassist.ca/METAGENassist). As sequencias não identificadas e taxonomias com abundância zero em 50\% das amostras foram removidas para análise pelo Metanagenassist (ARNDT et al., 2012).

A suposição de que as comunidades naturais contenham características especificas levou a série diversificada de análise dos índices ecológicos. Os índices ecológicos de diversidade, dominância, equitabilidade e riqueza foram avaliados utilizando o software PAST, incluindo as sequencias com singletons (UTOs com uma única sequência).

A caracterização microbiana foi realizada por meio de sequenciamento massivo do gene RNAr 16S utilizando a plataforma MiSeq, Illumina no tempo inicial (T0) e final (T2) do Ensaio de Remoção do PCB.

\subsection{Ensaios em Batelada}

As Hipóteses 1, 2, 3 e 4 foram avaliadas por meio da utilização de ensaios em reatores em batelada. Os reatores foram montados em triplicada, sob temperatura controlada $\left(30^{\circ} \mathrm{C} \pm 1^{\circ} \mathrm{C}\right)$ e agitação 
constante (150 rpm) (Figura 4-4 [c]). O reator em batelada foi composto por frasco de antibiótico de 100 $\mathrm{mL}$, cujo volume reacional foi de $25 \mathrm{~mL}$ (Figura 4-4 [a]).

De uma maneira geral para a realização dos ensaios em batelada, primeiro as espumas foram pesadas em cada frasco de antibiótico quando foi o caso (Ensaio de Inibição Metanogênica), depois procedeu-se a adição de meio de cultura(ANGELIDAKI et al., 2009)(ANGELIDAKI et al., 2009)(ANGELIDAKI et al., 2009)(ANGELIDAKI et al., 2009), bicarbonato de sódio, co-substratos, sulfeto de sódio sob condição metanogênica e nitrato de sódio sob condição desnitrificante.

A biomassa (10\% do volume reacional) foi inoculada sem troca de atmosfera para promover o crescimento da biomassa desnitrificante e sob atmosfera de $\mathrm{N}_{2}(100 \%)$ para estabelecer a anaerobiose dentro dos frascos sob condição metanogênica. Por último foi adicionado o PCB, totalizando sempre o volume reacional de $25 \mathrm{~mL}$. Todos os reatores foram fechados com tampa de teflon e, lacre de alumínio. 


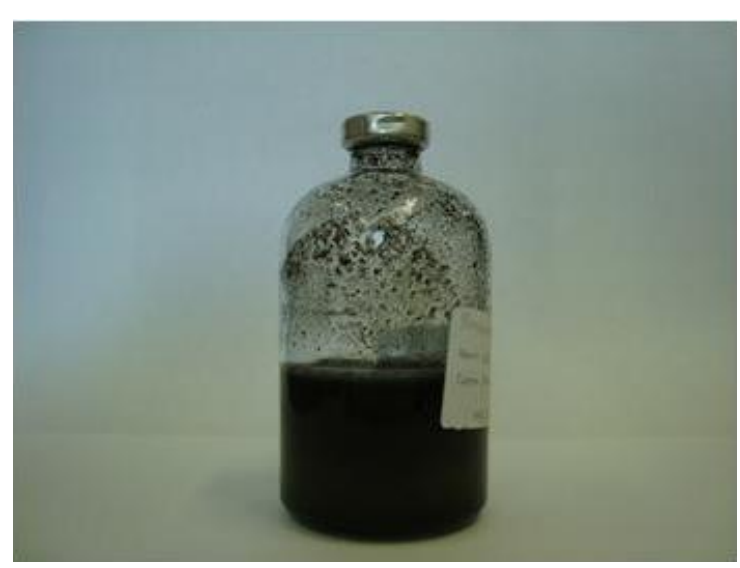

(a)

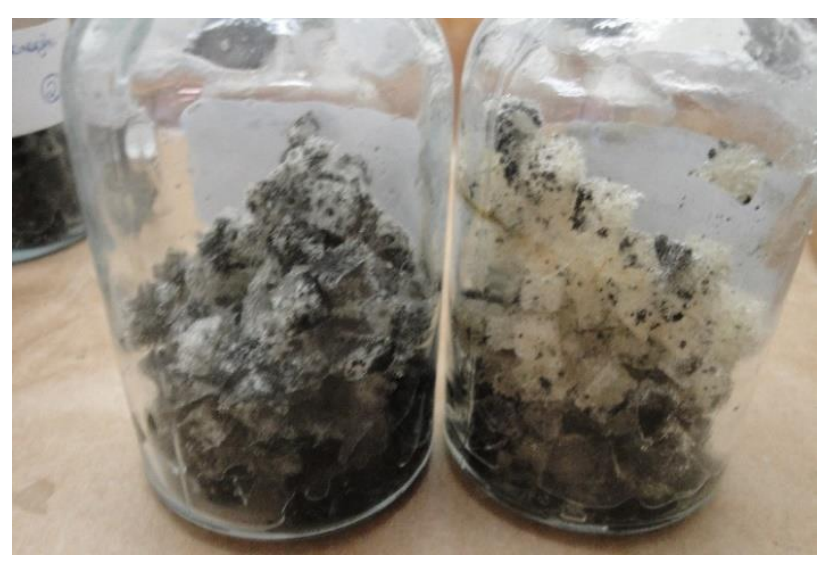

(b)

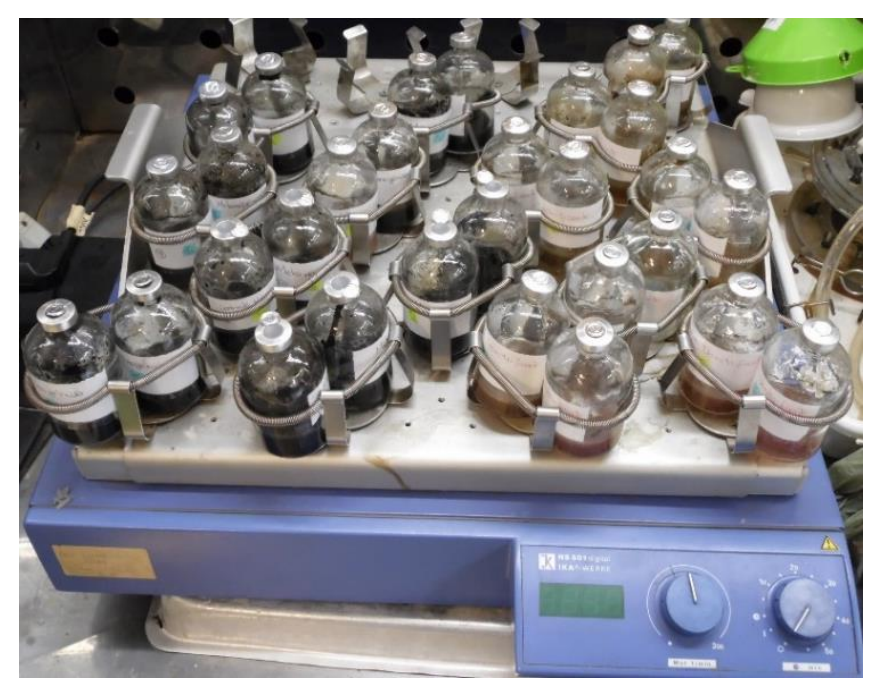

(c)

Figura 4-4 Reatores em batelada e agitador elétrico utilizados nos ensaios em batelada. (a) reator em batelada com meio sintético, co-substrato, PCB e inóculo utilizados em todos os ensaios; (b) espuma de poliuretano, evidenciando a biomassa aderida no material suporte utilizada apenas no ensaio de Inibição Metanogênica e (c) agitador elétrico utilizado operação dos reatores.

\subsubsection{Condição Anaeróbia}

\section{Ensaio de Inibição Metanogênica}

No Ensaio de Inibição Metanogênica foi avaliado indiretamente quais concentrações de PCB eram mais tóxicas para a comunidade metanogênica. Para tanto, foi avaliada a produção de metano para cada concentração de PCB em comparação com o reator controle, RC (sem adição de PCB). Nesses sistemas foram monitorados a produção de ácidos orgânicos voláteis e DQO. No reator denominado de Branco a biomassa inoculada foi inativada por meio de tratamento térmico. 
Dois ensaios em reatores em batelada foram conduzidos para avaliar a inibição causada pela presença do PCB na comunidade fermentativa-metanogênica (Figura 4-5). No primeiro ensaio avaliouse 0,5 mg. $\mathrm{L}^{-1}$, 1,5 mg. $\mathrm{L}^{-1}$ e 3,0 mg.L $\mathrm{L}^{-1}$ de PCB por trinta dias. No segundo avaliou-se 3,0 mg.L $\mathrm{L}^{-1}, 4,5$ mg. $\mathrm{L}^{-1}$ e $6,0 \mathrm{mg} . \mathrm{L}^{-1}$ de $\mathrm{PCB}$ por 34 dias.

\section{Ensaio Inibição Metanogênica}
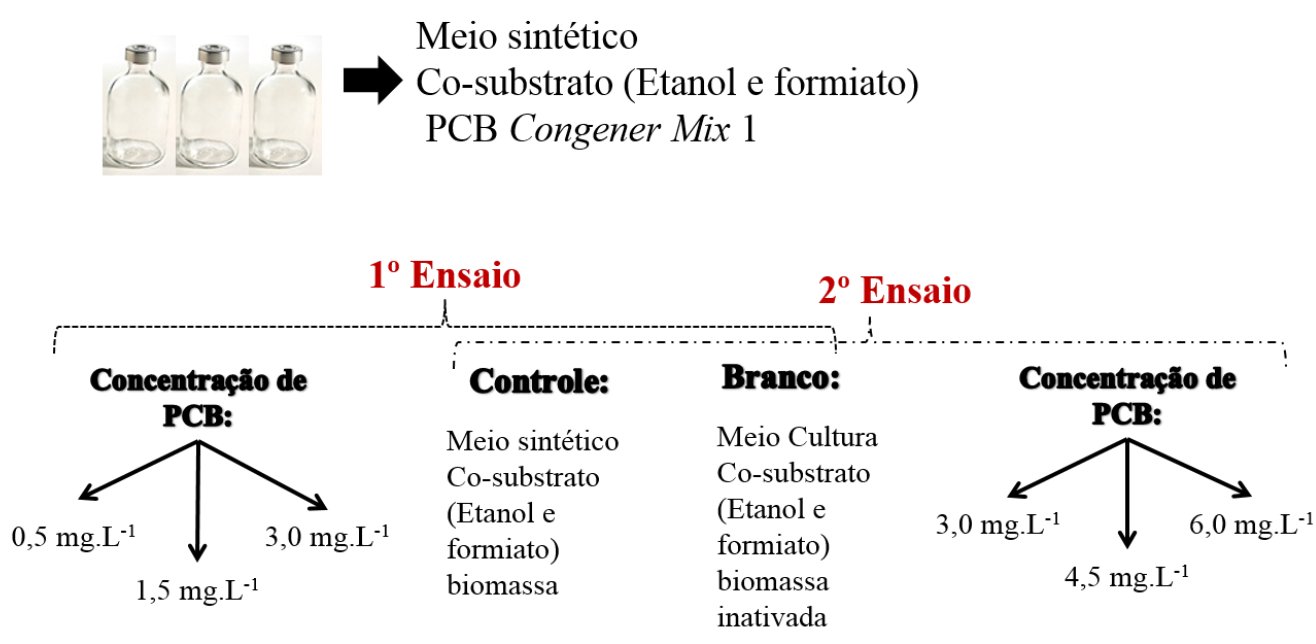

Acompanhar a produção de $\mathrm{CH}_{4}$, produção de ácidos orgânicos e remoção de DQO

Figura 4-5 Fluxograma do Ensaio de Inibição Metanogênica

Para a realização do ensaio em batelada, primeiro o material suporte foi pesado em cada frasco de antibiótico de $100 \mathrm{~mL}(0,31 \mathrm{~g})$. Procedeu-se a adição de meio de cultura (ANGELIDAKI et al., 2009), bicarbonato de sódio, co-substratos (etanol e formiato) e sulfeto de sódio $(0,05 \%)$. A biomassa (10\% do volume reacional) foi inoculada sob atmosfera de $\mathrm{N}_{2}(100 \%)$ para estabelecer a anaerobiose dentro dos frascos. Por último foi adicionado o PCB, totalizando volume reacional de $25 \mathrm{~mL}$ (Tabela 4-18 e Tabela 4-19). 
Tabela 4-18 Composição dos reatores em batelada no primeiro ensaio de inibição metanogênica.

\begin{tabular}{cccccc} 
& $\mathrm{RB}^{1}$ & $\mathrm{RC}^{2}$ & $\mathrm{R} 0,5$ & $\mathrm{R} 1,5$ & $\mathrm{R} 3,0$ \\
\hline $\begin{array}{c}\text { Material suporte } \\
(\mathrm{mg})\end{array}$ & 0,31 & 0,31 & 0,31 & 0,31 & 0,31 \\
\hline Biomassa $(\mathrm{mL})$ & 2,5 & 2,5 & 2,5 & 2,5 & 2,5 \\
\hline $\begin{array}{c}\text { Meio sintético } \\
(\mathrm{mL})\end{array}$ & 20,0 & 20,0 & 18,75 & 16,25 & 12,5 \\
\hline PCB $\left(\mathrm{mg} \cdot \mathrm{L}^{-1}\right)$ & - & - & 0,5 & 1,5 & 3,0 \\
\hline $\begin{array}{c}\text { Formiato de sódio } \\
\left(\mathrm{mg} \cdot \mathrm{L}^{-1}\right)\end{array}$ & 680 & 680 & 680 & 680 & 680 \\
\hline Etanol $\left(\mathrm{mg} \cdot \mathrm{L}^{-1}\right)$ & 457 & 457 & 457 & 457 & 457 \\
\hline Bicarbonato $\left(\mathrm{g} \cdot \mathrm{L}^{-1}\right)$ & 0,5 & 0,5 & 0,5 & 0,5 & 0,5 \\
\hline $\begin{array}{c}\text { Sulfeto de sódio } \\
(\%)\end{array}$ & 0,05 & 0,05 & 0,05 & 0,05 & 0,05 \\
\hline${ }^{1} \mathrm{RB}$ ou Reator Branco: inoculado com biomassa inativa por tratamento térmico (Controle negativo) \\
${ }^{2}$ RC ou Reator Controle: inoculado com biomassa sem adição de PCB (Controle positivo)
\end{tabular}

Tabela 4-19 Composição dos reatores em batelada no segundo ensaio de inibição metanogênica.

\begin{tabular}{|c|c|c|c|c|c|}
\hline & $\mathrm{RB}^{1}$ & $\mathrm{RC}^{2}$ & $\mathrm{R} 3,0$ & $\mathrm{R} 4,5$ & $\mathrm{R} 6,0$ \\
\hline $\begin{array}{l}\text { Material suporte } \\
(\mathrm{mg})\end{array}$ & 0,31 & 0,31 & 0,31 & 0,31 & 0,31 \\
\hline Biomassa (mL) & 2,5 & 2,5 & 2,5 & 2,5 & 2,5 \\
\hline $\begin{array}{l}\text { Meio sintético } \\
(\mathrm{mL})\end{array}$ & 20,0 & 20,0 & 12,5 & 8,75 & 5,0 \\
\hline PCB (mg. $\left.L^{-1}\right)$ & - & - & 3,0 & 4,5 & 6,0 \\
\hline $\begin{array}{l}\text { Formiato de sódio } \\
\left(\mathrm{mg} . \mathrm{L}^{-1}\right)\end{array}$ & 680 & 680 & 680 & 680 & 680 \\
\hline Etanol (mg.L $\left.\mathrm{L}^{-1}\right)$ & 457 & 457 & 457 & 457 & 457 \\
\hline Bicarbonato $\left(\mathrm{g} \cdot \mathrm{L}^{-1}\right)$ & 0,5 & 0,5 & 0,5 & 0,5 & 0,5 \\
\hline $\begin{array}{l}\text { Sulfeto de sódio } \\
(\%)\end{array}$ & 0,05 & 0,05 & 0,05 & 0,05 & 0,05 \\
\hline
\end{tabular}

A Inibição Metanogênica foi calculada com base na porcentagem de inibição que cada concentração de PCB induziu na comunidade metanogênica. Assim, a porcentagem da atividade metanogênica (\%AC) foi calculada dividindo-se a produção de gás de cada amostra pela produção de gás do reator controle (Equação 4-7) (OWEN et al., 1979).

Equação 4-7

$$
\% A C=\frac{\mathrm{CH}_{4_{A M O S T R A}}}{\mathrm{CH}_{4}{ }_{\text {CONTROLE }}} x 100
$$

Sendo:

$\% \mathrm{AC}=$ porcentagem da atividade metanogênica,

$\mathrm{CH}_{4}$ AMOSTRA $=$ produção máxima de metano nos reatores com PCB e

$\mathrm{CH}_{4}$ CONTROLE $=$ produção máxima de metano nos reatores sem adição de PCB.

A porcentagem de inibição $\left(\% \mathrm{I}_{\mathrm{M}}\right)$ foi definida como:

Equação 4-8

$$
\% I_{M}=100-\% A C
$$

Sendo: 
$\% \mathrm{I}_{\mathrm{M}}=$ porcentagem de inibição dos reatores com PCB e

$\% \mathrm{AC}=$ porcentagem da atividade metanogênica.

Os compostos que propiciam inibição de $50 \%$ e $80 \%$ são referidos como $\mathrm{IC}_{50}$ e $\mathrm{IC}_{80}$, respectivamente.

\section{Ensaio de Remoção de PCB}

Nesta etapa foi avaliada a remoção do PCB sob condição fermentativa-metanogênica por 101 dias. A biomassa foi inoculada em meio de cultura (ANGELIDAKI et al., 2009), com fonte de carbono (formiato de sódio e etanol) e PCB (Tabela 4-20). A biomassa utilizada nos reatores controle (CM) foi inativada por meio de tratamento térmico (3 vezes).

Tabela 4-20 Condição do ensaio em batelada para avaliar a remoção do PCB em condição fermentativametanogênica.

\begin{tabular}{|c|c|c|}
\hline & $\mathrm{CM}^{1}$ & $\mathrm{M}^{2}$ \\
\hline Biomassa (mL) & 2,5 & 2,5 \\
\hline Meio de cultura (mL) & 16,25 & 16,25 \\
\hline $\mathrm{PCB}\left(\mathrm{mg} \cdot \mathrm{L}^{-1}\right)$ & 1,5 & 1,5 \\
\hline Formiato de sódio (mg.L $\left.\mathrm{L}^{-1}\right)$ & 680 & 680 \\
\hline Etanol $\left(m g . L^{-1}\right)$ & 457 & 457 \\
\hline Bicarbonato (g.L $\left.\mathrm{L}^{-1}\right)$ & 0,5 & 0,5 \\
\hline Sulfeto de sódio (\%) & 0,05 & 0,05 \\
\hline
\end{tabular}

A atividade metanogênica foi avaliada durante todo o tempo de operação dos reatores por meio da análise do headspace em cromatógrafo gasoso. O lodo proveniente do reator UASB da avícola Dakar utilizado neste ensaio foi armazenado em geladeira por volta de 10 meses, assim antes de ser utilizado foi aclimatado por uma semana a $30^{\circ} \mathrm{C}$ para ativação dos microrganismos.

As análises de quantificação de PCB, análises físico-químicas e amostras para a caracterização da comunidade microbiana foram realizadas no tempo inicial (T0), com 81 dias (T1) e 101 dias (T2). A concentração teórica adicionada nos reatores foi de 1,5 mg. $\mathrm{L}^{-1}$ de PCB, e a partir dessa concentração foi calculada a porcentagem de adsorção de cada congêneres de PCB no lodo anaeróbio (biossorção) por meio da análise da concentração dos congêneres de PCB nos reatores controle (CM), inoculados com biomassa inativada (Equação 4-9).

Equação 4-9

$$
\% \text { Biosso }=\left(\frac{[P C B]_{T}-[P C B]_{R}}{[P C B]_{T}}\right) x 100
$$

Sendo:

$\%$ Biosso = porcentagem de biossorção nos reatores controle,

$[\mathrm{PCB}]_{\mathrm{T}}=$ concentração teórica de PCB adicionada nos reatores controle, no caso $1,5 \mathrm{mg} . \mathrm{L}^{-1}$, $[\mathrm{PCB}]_{\mathrm{R}}=$ concentração real do PCB nos reatores controle, por meio de análise cromatográfica. 
A partir da análise cromatográfica do PCB nos reatores metanogênicos (M), foi calculado a eficiência de remoção de cada congênere de PCB através da concentração removida de PCB (Equação 4-10).
Equação 4-10

$$
R_{P C B}=\left(\frac{[P C B]_{T 0}-[P C B]_{T 2}}{[P C B]_{T 0}}\right) x 100
$$
Sendo:
$\mathrm{R}_{\mathrm{PCB}}=$ eficiência de remoção de PCB para cada congênere, $[\mathrm{PCB}]_{\mathrm{T} 0}=$ concentração inicial de PCB nos reatores no tempo T0, $[\mathrm{PCB}]_{\mathrm{T} 2}=$ concentração final de PCB nos reatores no tempo T2.

\subsubsection{Condição Anóxica}

\section{Ensaio de Relação Carbono e Nitrogênio}

A desnitrificação é a redução de compostos nitrogenados, como o nitrato $\left(\mathrm{NO}_{3}{ }^{-}\right)$e o nitrito $\left(\mathrm{NO}_{2}{ }^{-}\right.$ ) resultando na formação de nitrogênio gasoso $\left(\mathrm{N}_{2}\right)$ pelo catabolismo de bactérias anóxicas. Este processo é realizado com a utilização de fontes de carbono biodegradáveis, tais como acetato e etanol (AKUNNA; BIZEAU; MOLETTA, 1992; DRTIL et al., 1995; PERCHERON et al., 1998; SANTOS et al., 2004; TCHOBANOGLOUS; BURTON; STENSEL, 2003; PENG; MA; WANG, 2007; ADAV; LEE; LAI, 2010). Diferentes fontes de carbono e de relação carbono e nitrogênio no sistema (relação C/N) produz diferentes taxas de desnitrificação (MONTEITH; BRIDLE; SUTTON, 1980; SKRINDE; BHAGAT, 1982; HER; HUANG, 1995).

A relação ideal $\mathrm{C} / \mathrm{N}$ no sistema desnitrificante sob condições especificas, como a presença de tóxico, deve ser calculada experimentalmente (CHIU; CHUNG, 2003). Assim, o Ensaio de Relação Carbono e Nitrogênio foi conduzido para estabelecer qual a relação ideal na presença de PCB. Os reatores foram inoculados com lodos ativados não-adaptados, etanol $\left(598,9 \mathrm{mg} . \mathrm{L}^{-1}\right)$, meio sintético e diferentes relações de $\mathrm{C} / \mathrm{N}-\mathrm{NO}_{3}$.

Como a relação $\mathrm{C} / \mathrm{N}$ ideal para um sistema é diretamente influenciada pela fonte de carbono e a melhor relação C/N deve ser determinada experimentalmente (CHIU; CHUNG, 2003), foi realizado

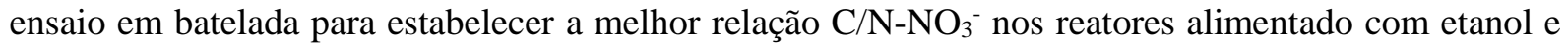
em presença de PCB sob condição desnitrificante (Tabela 4-21). Este ensaio foi realizado com a adição de 1,5 mg. L $^{-1}$ de PCB. As três relações 6,6:1, 3,5:1 e 1,8:1 foram baseadas em trabalhos que utilizaram condição desnitrificante para a remoção de compostos aromáticos (CHIU; CHUNG, 2003; SARFARAZ et al., 2004; MARTÍNEZ-HERNÁNDEZ et al., 2009). Já a relação 138:1 foi escolhida com base na composição das células dos microrganismos, que se refere à concentração de nitrogênio descrita como mínima para atender as necessidades de macronutrientes dos organismos (RITTMANN; MCCARTY, 2001). 
Tabela 4-21 Condição dos ensaios em batelada para avaliar a melhor Relação $\mathrm{C} / \mathrm{N}-\mathrm{NO}_{3}{ }^{-}$na presença de PCB.

\begin{tabular}{|c|c|c|c|c|}
\hline & \multicolumn{4}{|c|}{ Relação $\mathrm{C} / \mathrm{N}_{-} \mathrm{NO}_{3}{ }^{-}$} \\
\hline & $138: 1$ & $6,6: 1$ & $3,5: 1$ & $1,8: 1$ \\
\hline Meio Angelidaki (mL) & 18,50 & 18,05 & 17,75 & 17,00 \\
\hline PCB $\left(\mathrm{mg} \cdot \mathrm{L}^{-1}\right)$ & 1,5 & 1,5 & 1,5 & 1,5 \\
\hline Etanol $\left(\mathrm{mg} . \mathrm{L}^{-1}\right)$ & 598 & 598 & 598 & 598 \\
\hline Bicarbonato $\left(\mathrm{g} . \mathrm{L}^{-1}\right)$ & 0,5 & 0,5 & 0,5 & 0,5 \\
\hline Biomassa $(\mathrm{mL})$ & 2,5 & 2,5 & 2,5 & 2,5 \\
\hline $\mathrm{N}-\mathrm{NO}_{3}\left(\mathrm{mg} \cdot \mathrm{L}^{-1}\right)$ & 21,0 & 437,5 & 833,3 & 1614,3 \\
\hline
\end{tabular}

As relações $\mathrm{C} / \mathrm{N}-\mathrm{NO}_{3}{ }^{-}$foram calculadas por meio da seguinte equação:

\section{Equação 4-11}

$$
\operatorname{RelaçãoC} / N=\frac{C-D Q O}{N-N O_{3}^{-}}
$$

Sendo:

C-DQO = quantificação de carbono por meio da análise de DQO $\left(\mathrm{mgO}_{2} \cdot \mathrm{L}^{-1}\right) \mathrm{e}$ $\mathrm{N}-\mathrm{NO}_{3}{ }^{-}=$quantificação de nitrogênio na forma de nitrato em mg. $\mathrm{L}^{-1}$.

Para estabelecimento da Relação $\mathrm{C} / \mathrm{N}-\mathrm{NO}_{3}{ }^{-}$ideal na presença de PCB foi utilizada a metodologia descrita por Chiu; Chung (2003), determinada diretamente pelo gráfico de consumo de $\mathrm{NO}_{3}$. Utilizando os resultados de nitrato encontrado em cada reator, um gráfico de $\mathrm{NO}_{3}$ residual versus Relação de $\mathrm{C} / \mathrm{N}-\mathrm{NO}_{3}{ }^{-}$nos reatores foi plotado, e a partir da intersecção do gráfico foi calculado a Relação $\mathrm{C} / \mathrm{N}_{-} \mathrm{NO}_{3}^{-}$ideal na presença de PCB.

\section{Ensaio de Inibição Desnitrificante}

No Ensaio de Inibição Desnitrificante foi avaliada indiretamente as concentrações de PCB mais tóxicas para a comunidade redutora de nitrato. Para tanto, foi monitorado o consumo de nitrato para cada concentração de $\mathrm{PCB}$, produção de ácidos orgânicos voláteis e DQO em todos os reatores em comparação com o reator controle, RC (sem PCB) (Figura 4-3). O resultado negativo foi evidenciado pelo reator Branco (RB), em que a biomassa inoculada foi inativada anteriormente por meio da tratamento térmico.

A melhor relação $\mathrm{C} / \mathrm{N}-\mathrm{NO}_{3}$ para $1,4 \mathrm{mg} \cdot \mathrm{L}^{-1}$ de $\mathrm{PCB}$ obtida no Ensaio Relação Carbono e Nitrogênio foi utilizada no ensaio de inibição desnitrificante e no Ensaio de Remoção de PCB. 


\section{Ensaio Inibição Desnitrificante}

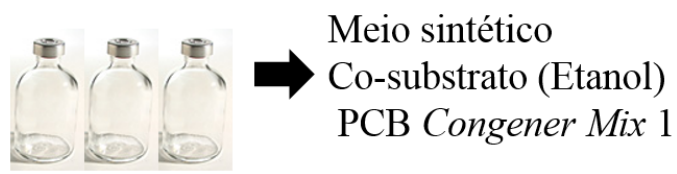

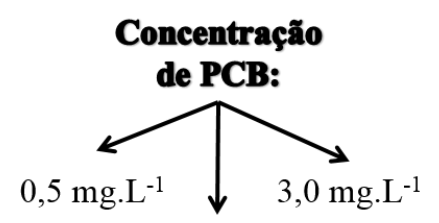

$1,5 \mathrm{mg} \cdot \mathrm{L}^{-1}$

\section{Controle:}

Meio sintético

Fontes de C (Etanol)

biomassa

\section{Branco:}

Meio Cultura

Fontes de C (Etanol)

biomassa inativada

Acompanhar a remoção de $\mathrm{NO}_{3}^{-}$, produção de ácidos orgânicos e remoção de DQO

Figura 4-6 Etapas do Ensaio de Inibição Desnitrificante.

No ensaio de Inibição Desnitrificante foi avaliado $0,5 \mathrm{mg} . \mathrm{L}^{-1}, 1,5 \mathrm{mg} . \mathrm{L}^{-1}$ e $3,0 \mathrm{mg} . \mathrm{L}^{-1}$ de PCB, nos reatores R0,5, R1,5 e R3,0, respectivamente. Para a realização do ensaio em batelada, em cada frasco de antibiótico de $100 \mathrm{~mL}$ foram adicionados bicarbonato de sódio $(12,5 \mathrm{mg}$ ), co-substrato (etanol) conjuntamente com o meio sintético (ANGELIDAKI et al., 2009). Posteriormente, os reatores foram inoculados com biomassa (10\% do volume reacional) e por último foi adicionado o PCB, compondo o volume total de $25 \mathrm{~mL}$ (Tabela 4-22).

Tabela 4-22 Condição dos ensaios em batelada para avaliar a taxa de inibição desnitrificante gerada pelo PCB.

\begin{tabular}{|c|c|c|c|c|}
\hline & $\mathrm{RC}$ & $\mathrm{R} 0,5$ & $\mathrm{R} 1,5$ & $\mathrm{R} 3,0$ \\
\hline $\begin{array}{l}\text { Meio Angelidaki } \\
(\mathrm{mL})\end{array}$ & 21,8 & 20,55 & 18,05 & 14,3 \\
\hline PCB $\left(\mathrm{mg} \cdot \mathrm{L}^{-1}\right)$ & 0 & 0,5 & 1,5 & 3,0 \\
\hline Etanol $\left(\mathrm{mg} \cdot \mathrm{L}^{-1}\right)$ & 598 & 598 & 598 & 598 \\
\hline Bicarbonato $\left(\mathrm{g} . \mathrm{L}^{-1}\right)$ & 0,5 & 0,5 & 0,5 & 0,5 \\
\hline Biomassa $(\mathrm{mL})$ & 2,5 & 2,5 & 2,5 & 2,5 \\
\hline $\mathrm{N}-\mathrm{NO}_{3}{ }^{-}\left(\mathrm{mg} \cdot \mathrm{L}^{-1}\right)^{1}$ & 151,5 & 256,9 & 362,3 & 579,8 \\
\hline
\end{tabular}

A análise da Inibição Desnitrificante foi calculada por meio da porcentagem de inibição que cada concentração de PCB induziu na comunidade anóxica. Assim, foi utilizado a Eficiência de Desnitrificação $\left(\mathrm{E}_{\mathrm{D}}\right)$, ou eficiência de remoção de $\mathrm{NO}_{\mathrm{x}}\left(\mathrm{NO}_{3}{ }^{-}\right.$e $\left.\mathrm{NO}_{2}{ }^{-}\right)$. Como a acumulação de nitrito nos sistemas desnitrificantes pode superestimar a eficiência de desnitrificação (HER; HUANG, 1995), 
a eficiência foi calculada a partir da concentração de $\mathrm{NO}_{3}^{-}$(nitrato) e $\mathrm{NO}_{2}^{-}$(nitrito) nos reatores de acordo com a Equação 4-12.

\section{Equação 4-12 $\quad I_{D}=E_{D}$ controle $-E_{D}$ reatores}

Sendo:

$\mathrm{I}_{\mathrm{D}}=$ inibição desnitrificante calculada para cada concentração de PCB

$E_{D}$ controle $=$ eficiência de desnitrificação nos reatores sem PCB (RC);

EDreatores $=$ eficiência de desnitrificação nos reatores com PCB (R0,5, R1,5 e R3,0).

III. Ensaio de Remoção de PCB

Nesta etapa foi avaliada a remoção do PCB por parte da comunidade anóxica (desnitrificante). Os reatores em batelada foram operados por volta de 100 dias, inoculado em meio sintético (ANGELIDAKI et al., 2009), etanol (598 mg.L $\left.\mathrm{L}^{-1}\right)$ e PCB (1,5mg.L $\mathrm{L}^{-1}$ ) (Tabela 4-23). O nitrato de sódio $\left(\mathrm{NaNO}_{3}\right)$ foi adicionado como fonte de nitrato $\left(1.652,2 \mathrm{mg} \cdot \mathrm{L}^{-1} \mathrm{de} \mathrm{NO}_{3}{ }^{-}\right)$. A biomassa do reator controle desnitrificante $(\mathrm{CD})$ foi inativada por meio da tratamento térmico (3 vezes).

Tabela 4-23. Reatores desnitrificante do ensaio em batelada para avaliar a remoção do PCB.

\begin{tabular}{|c|c|c|}
\hline & $\mathrm{CD}^{1}$ & $\mathrm{D}^{2}$ \\
\hline Biomassa (mL) & 2,5 & 2,5 \\
\hline Meio de cultura (mL) & 14,3 & 14,3 \\
\hline PCB (mg.L L $\left.^{-1}\right)$ & 1,5 & 1,5 \\
\hline Etanol (mg.L.' & 598 & 598 \\
\hline Bicarbonato (g.L $\mathrm{L}^{-1}$ ) & 0,5 & 0,5 \\
\hline $\mathrm{N}-\mathrm{NO}_{3}^{-}\left(\mathrm{mg} \cdot \mathrm{L}^{-1}\right)$ & 373,0 & 373,0 \\
\hline
\end{tabular}

$\mathrm{O}$ crescimento das bactérias desnitrificantes foi avaliado indiretamente pela Eficiência de Desnitrificação $\left(E_{D}\right)$ que representa a taxa de consumo do nitrato adicionado no meio.

As análises de quantificação de PCB, análises físico-químicas e amostras para a caracterização da comunidade microbiana foram realizadas no tempo inicial (T0), com 79 dias (T1) e 99 dias (T2).

A concentração teórica adicionada nos reatores foi de $1,5 \mathrm{mg} \cdot \mathrm{L}^{-1}$ de $\mathrm{PCB}$, e a partir dessa concentração foi calculada a porcentagem de adsorção de cada congêneres de PCB no lodo anóxico (biossorção) por meio da análise da concentração dos congêneres de PCB nos reatores controle (CD), inoculados com biomassa inativada (Equação 4-13).

Equação 4-13

$$
\% \text { Biosso }=\left(\frac{[P C B]_{T}-[P C B]_{R}}{[P C B]_{T}}\right) x 100
$$

Sendo:

$\%$ Biosso $=$ porcentagem de biossorção nos reatores controle 
$[\mathrm{PCB}]_{\mathrm{T}}=$ concentração teórica de PCB adicionada nos reatores controle, no caso $1,5 \mathrm{mg} \cdot \mathrm{L}^{-1}$, $[\mathrm{PCB}]_{\mathrm{R}}=$ concentração real do PCB nos reatores controle, por meio de análise cromatográfica.

A partir da análise cromatográfica do PCB nos reatores desnitrificantes (D), foi calculado a eficiência de remoção de cada congênere de PCB através da concentração removida de PCB (Equação 4-14).

Equação 4-14 $\quad R_{P C B}=\left(\frac{[P C B]_{T 0}-[P C B]_{T 2}}{[P C B]_{T 0}}\right) x 100$

Sendo:

$\mathrm{R}_{\mathrm{PCB}}=$ eficiência de remoção de PCB para cada congênere,

$[\mathrm{PCB}]_{\mathrm{T} 0}=$ concentração inicial de PCB nos reatores no tempo T0,

$[\mathrm{PCB}]_{\mathrm{T} 2}=$ concentração final de PCB nos reatores no tempo T2. 


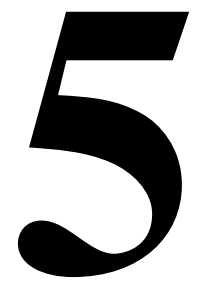

\section{Resultados e Discussão}

\subsection{Desenvolvimento e validação de método para determinação de PCB via SPME}

A técnica de extração de PCB por meio do SPME foi avaliada e aperfeiçoada comparando-se a eficiência da extração com a adição de $\mathrm{NaCl}$, diferentes concentrações de PCB, tempo de extração, tipo de fibra e adição de padrão interno.

A primeira avaliação foi relacionada à seletividade do método de extração e quantificação. A análise da seletividade é necessária para não superestimar a concentração do composto de interesse e refere-se a capacidade em detectar os analitos de interesse na presença de outros componentes da matriz por meio da aplicação do método analítico (CHASIN et al., 1998; RIBANI et al., 2004). A seletividade pode ser obtida de diversas maneiras. Dentre essas a escolhida neste trabalho foi comparar a matriz sem PCB (somente o meio de cultura e fontes orgânicas) com a matriz fortificada com PCB $\left(0,2 \mathrm{mg} . \mathrm{L}^{-1}\right)$ (Figura 5-1).

Neste caso, verificou-se para os compostos da matriz sem PCB tempo de retenção por volta de 1,960 e 2,137 minutos, os quais foram visualizados antes dos picos dos PCBs, cujo tempo de retenção foi em torno de 3,925, 4,982, 5,277, 6,852, 7,176 e 7,962 minutos. Neste sentido, verificou-se para todos os compostos do meio de cultura sintético tempos de retenção distintos daqueles encontrados para os analitos de interesse, e seletividade do método foi alcançada (Figura 5-1). 


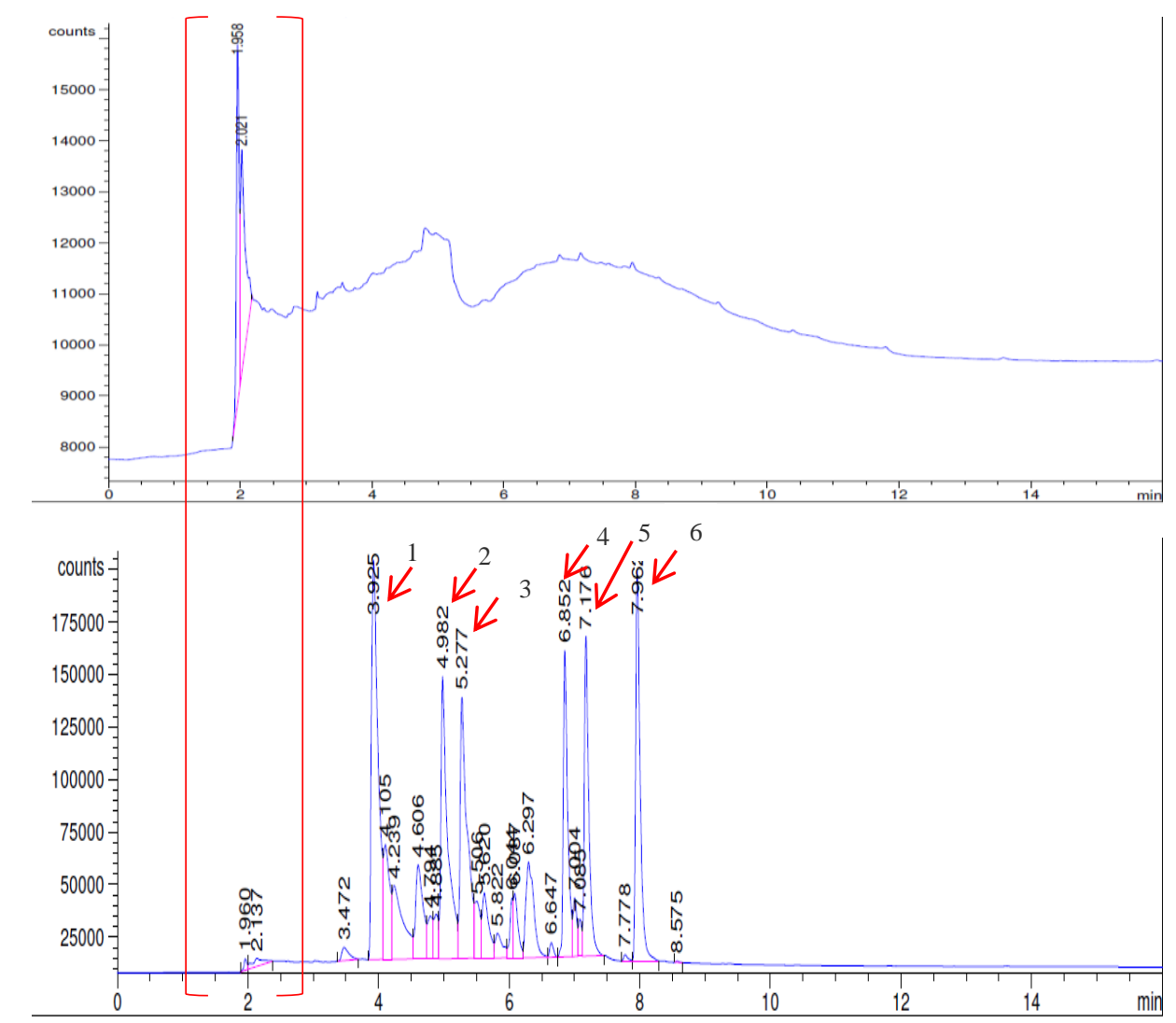

Figura 5-1 Análise da seletividade da extração por meio da técnica de SPME. (a) Cromatograma da análise da matriz isenta de PCB (Tempo de extração 15 minutos, temperatura ambiente de extração); (b) matriz adicionada de PCB (0,2 mg. $\mathrm{L}^{-1} \mathrm{PCB}$, tempo de extração 15 minutos, temperatura ambiente de extração). PCB 10 (Pico 1), PCB 28 (Pico 2), PCB 52 (Pico 3), PCB 153 (Pico 4), PCB 138 (Pico 5) e PCB 180 (Pico 6 ).

Retenção na cromatografia é o resultado de um processo de distribuição competitiva de soluto entre as fases móveis e fixas, em que a separação do soluto entre estas fases é em grande parte determinada pela estrutura molecular. Segundo Ren et al. (2007), o tempo de retenção cromatográfica dos compostos clorados depende diretamente do número de cloro e posição inserida na molécula de bifenila. Assim neste trabalho, os diferentes tempos de retenção foram relacionados diretamente com os diferentes congêneres de PCB (Tabela 5-1), sendo os primeiros picos considerados com menos cloro.

Tabela 5-1 Relação entre os picos obtidos no cromatograma, tempo de retenção e congêneres de PCBs.

\begin{tabular}{|c|c|c|c|c|c|}
\hline & Congêneres & $\begin{array}{l}\text { Quantidade } \\
\text { de cloro }\end{array}$ & $\begin{array}{l}\text { Tempo de } \\
\text { retenção neste } \\
\text { trabalho }\end{array}$ & $\begin{array}{l}\text { Tempo de } \\
\text { retenção na } \\
\text { literatura1 }\end{array}$ & Pico \\
\hline PCB 10 & 2,6-diclorobifenil & 2 & $3,92 \pm 0,01$ & 2,58 & 1 \\
\hline PCB 28 & 2,4,4'-triclorobifenil & 3 & $4,98 \pm 0,01$ & 4,08 & 2 \\
\hline PCB 52 & $2,2^{\prime}, 5,5^{\prime}$-tetraclorobifenil & 4 & $5,28 \pm 0,01$ & 4,39 & 3 \\
\hline PCB 153 & $2,2^{\prime}, 4,4^{\prime}, 5,5^{\prime}$-hexaclorobifenil & 6 & $6,85 \pm 0,01$ & 6,37 & 4 \\
\hline PCB 138 & $2,2^{\prime}, 3,4,4^{\prime}, 5^{\prime}$-hexaclorobifenil & 6 & $7,18 \pm 0,01$ & 6,56 & 5 \\
\hline PCB 180 & $2,2^{\prime}, 3,4,4^{\prime}, 5,5^{\prime}$-heptaclorobifenil & 7 & $7,96 \pm 0,01$ & 7,41 & 6 \\
\hline
\end{tabular}

No segundo teste foram adicionadas diferentes concentrações de $\mathrm{NaCl}$ nas amostras. As condições avaliadas foram sem $\mathrm{NaCl}$, e com $0,5 \mathrm{~g}$ e $1,0 \mathrm{~g}$ de $\mathrm{NaCl}$ (Tabela 5-2). 
Tabela 5-2 Condições de extração para o teste com diferentes concentrações de NaCl para a técnica de SPME.

\begin{tabular}{|c|c|c|c|c|c|c|c|c|c|}
\hline Amostra & $\begin{array}{l}\text { Fibra de } \\
\text { SMPE }\end{array}$ & $\begin{array}{c}\text { Concentração } \\
\text { PCB (mg/L) }\end{array}$ & $\begin{array}{c}\text { Volume de } \\
\text { amostra } \\
(\mathrm{mL})\end{array}$ & $\mathrm{NaCl}(\mathrm{g})$ & $\begin{array}{l}\text { Temperatur } \\
\text { a Extração } \\
\left({ }^{\circ} \mathrm{C}\right)\end{array}$ & $\begin{array}{l}\text { Temperatura de } \\
\text { dessorção }\left({ }^{\circ} \mathrm{C}\right)\end{array}$ & $\begin{array}{c}\text { Tempo de } \\
\text { extração (min) }\end{array}$ & \multicolumn{2}{|c|}{$\begin{array}{c}\text { Desvio padrão } \\
\text { Tempo } \\
\text { retenção }\end{array}$} \\
\hline \multirow{6}{*}{$\begin{array}{l}\mathrm{PCB}+ \\
\text { Meio }\end{array}$} & \multirow{6}{*}{$\begin{array}{l}\text { PDMS } \\
(100 \mu \mathrm{m})\end{array}$} & \multirow{6}{*}{1,5} & \multirow{6}{*}{2,0} & \multirow{6}{*}{0} & \multirow{6}{*}{22} & \multirow{6}{*}{250} & \multirow{6}{*}{15} & 1 & 0,04 \\
\hline & & & & & & & & 2 & 0,05 \\
\hline & & & & & & & & 3 & 0,05 \\
\hline & & & & & & & & 4 & 0,03 \\
\hline & & & & & & & & 5 & 0,03 \\
\hline & & & & & & & & 6 & 0,03 \\
\hline \multirow{6}{*}{$\begin{array}{c}\mathrm{PCB}+ \\
\text { Meio }\end{array}$} & \multirow{6}{*}{$\begin{array}{l}\text { PDMS } \\
(100 \mu \mathrm{m})\end{array}$} & \multirow{6}{*}{1,5} & \multirow{6}{*}{2,0} & \multirow{6}{*}{0,5} & \multirow{6}{*}{22} & \multirow{6}{*}{250} & \multirow{6}{*}{15} & 1 & 0,04 \\
\hline & & & & & & & & 2 & 0,03 \\
\hline & & & & & & & & 3 & 0,02 \\
\hline & & & & & & & & 4 & 0,01 \\
\hline & & & & & & & & 5 & 0,01 \\
\hline & & & & & & & & 6 & 0,01 \\
\hline \multirow{6}{*}{$\begin{array}{l}\mathrm{PCB}+ \\
\text { Meio }\end{array}$} & \multirow{6}{*}{$\begin{array}{l}\text { PDMS } \\
(100 \mu \mathrm{m})\end{array}$} & \multirow{6}{*}{1,5} & \multirow{6}{*}{2,0} & \multirow{6}{*}{1,0} & \multirow{6}{*}{22} & \multirow{6}{*}{250} & \multirow{6}{*}{15} & 1 & 0,02 \\
\hline & & & & & & & & 2 & 0,02 \\
\hline & & & & & & & & 3 & 0,01 \\
\hline & & & & & & & & 4 & 0,01 \\
\hline & & & & & & & & 5 & 0,01 \\
\hline & & & & & & & & 6 & 0,02 \\
\hline
\end{tabular}

${ }^{1}$ Desvio Padrão do Tempo de retenção de cada congenere PCB 10 (Pico 1), PCB 28 (Pico 2), PCB 52 (Pico 3), PCB 153 (Pico 4), PCB 138 (Pico 5) e PCB 180 (Pico 6)

A partir dos cromatogramas obtidos pode-se verificar que a utilização de $\mathrm{NaCl}$ foi mais favorável para a extração do PCB por meio do efeito salting-out, visto que o coeficiente de variação na presença de $0,5 \mathrm{~g}$ de sal foram menores para todos os picos (entre 0,01 a 0,04 ) e as áreas de cada pico foram mais elevadas (entre 1.000.000 e 12.000.000), aumentando a precisão da extração (Figura 5-2).

O efeito de salting-out diminui a polaridade da molécula do soluto e aumenta o particionamento de compostos orgânicos da fase líquida para a fase gasosa. Sais como o $\mathrm{NaCl}$ que consistem em pequenos íons, melhoram a estruturação da fase aquosa e, portanto, a energia de coesão da água devido as suas fortes interações. $\mathrm{O}$ aumento da energia de coesão tem vários efeitos sobre as propriedades da fase aquosa, e resultam principalmente no aumento da eficiência de extração de procedimentos analíticos como na técnica de SPME (ENDO; PFENNIGSDORFF; GOSS, 2012). Assim, a adição de 0,5g de NaCl foi elegido como uma condição adequada para as análises cromatográficas de PCB nas etapas posteriores. Adorno (2013) avaliou a extração de PCB por cromatografia gasosa e detector de captura de elétrons em óleo Ascarel, reator anaeróbio e solo e evidenciou melhores eficiências de extração na presença de $\mathrm{NaCl}$. 


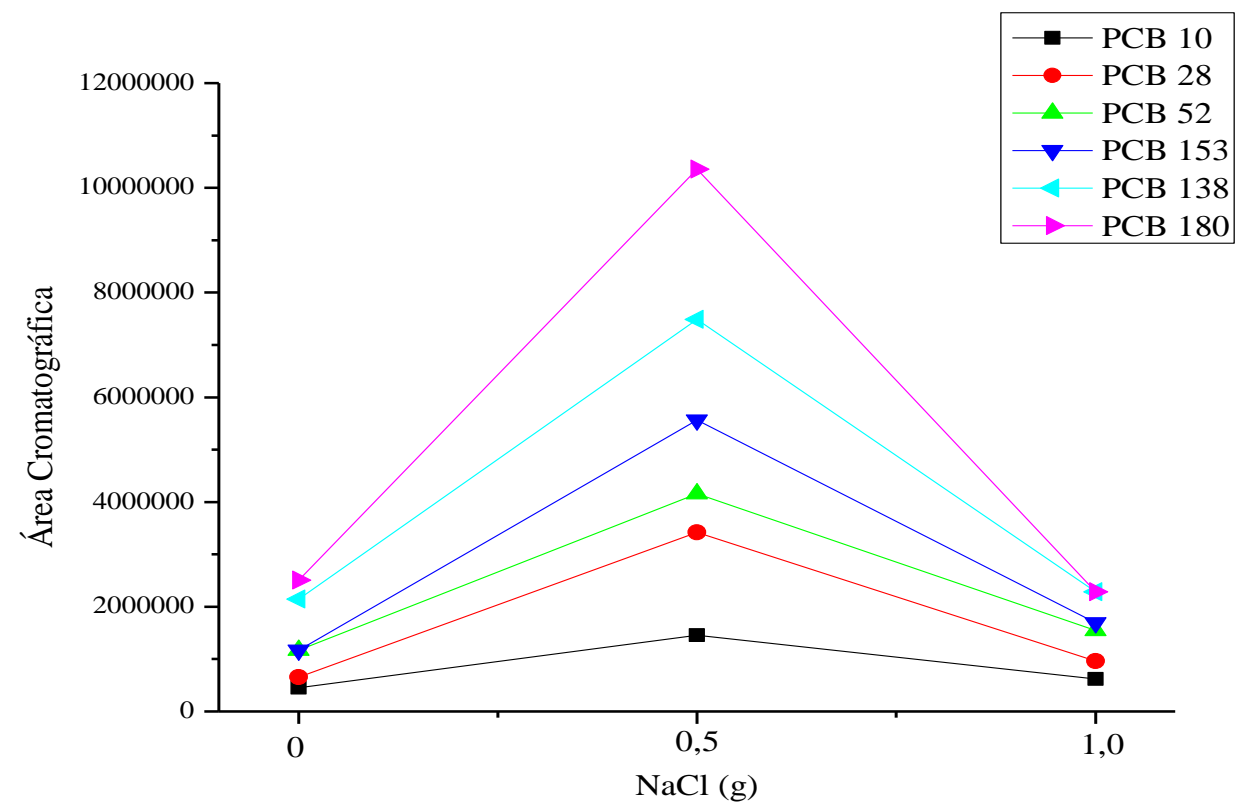

Figura 5-2 Área cromatográfica de cada congênere de PCB em diferentes concentrações de NaCl na extração por SPME.

Três tipos de fibras foram testadas em relação a extração de PCB: PDMS (Dimetil polissiloxano), com espessura de $100 \mu \mathrm{m}$, PDMS/DVB (Dimetil polissiloxano e Divinilbenzeno) com espessura de $65 \mu \mathrm{m}$ e Carboxen/PDMS (Carboxen e Dimetil polissiloxano) com espessura de $75 \mu \mathrm{m}$ (Tabela 5-3). 
Tabela 5-3 Condição dos testes para a escolha do tipo de fibra na extração de PCB utilizando a técnica de SPME.

\begin{tabular}{|c|c|c|c|c|c|c|c|c|c|}
\hline Amostra & $\begin{array}{l}\text { Fibra de } \\
\text { SMPE }\end{array}$ & $\begin{array}{c}\text { Concentração } \\
\text { PCB } \\
(\mathrm{mg} / \mathrm{L})\end{array}$ & $\begin{array}{l}\text { Volume de } \\
\text { amostra } \\
(\mathrm{mL})\end{array}$ & $\begin{array}{c}\mathrm{NaCl} \\
(\mathrm{g})\end{array}$ & $\begin{array}{l}\text { Temperatura } \\
\text { Extração } \\
\left({ }^{\circ} \mathrm{C}\right)\end{array}$ & $\begin{array}{l}\text { Temperatura } \\
\text { de dessorção } \\
\left({ }^{\circ} \mathrm{C}\right)\end{array}$ & $\begin{array}{l}\text { Tempo de } \\
\text { extração } \\
\text { (min) }\end{array}$ & Des & $\begin{array}{l}\text { o padrão } \\
\text { empo } \\
\text { enção }\end{array}$ \\
\hline \multirow{6}{*}{$\begin{array}{c}\mathrm{PCB}+ \\
\text { Meio }\end{array}$} & \multirow{6}{*}{$\begin{array}{l}\text { Carboxen/ } \\
\text { PDMS } \\
(75 \mu \mathrm{m})\end{array}$} & \multirow{6}{*}{1,5} & \multirow{6}{*}{$2,0 \mathrm{~mL}$} & \multirow{6}{*}{1,0} & \multirow[t]{6}{*}{ 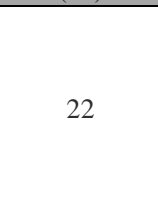 } & \multirow{6}{*}{250} & \multirow{6}{*}{15} & 1 & 0,01 \\
\hline & & & & & & & & 2 & 0,02 \\
\hline & & & & & & & & 3 & 0,02 \\
\hline & & & & & & & & 4 & 0,05 \\
\hline & & & & & & & & 5 & 0,06 \\
\hline & & & & & & & & 6 & 0,07 \\
\hline \multirow{6}{*}{$\begin{array}{l}\mathrm{PCB}+ \\
\text { Meio }\end{array}$} & \multirow{6}{*}{$\begin{array}{c}\text { PDMS/DVB } \\
(65 \mu \mathrm{m})\end{array}$} & \multirow{6}{*}{1,5} & \multirow{6}{*}{$2,0 \mathrm{~mL}$} & \multirow{6}{*}{1,0} & \multirow{6}{*}{22} & \multirow{6}{*}{250} & \multirow{6}{*}{15} & 1 & 0,02 \\
\hline & & & & & & & & 2 & 0,01 \\
\hline & & & & & & & & 3 & 0,01 \\
\hline & & & & & & & & 4 & 0,00 \\
\hline & & & & & & & & 5 & 0,00 \\
\hline & & & & & & & & 6 & 0,00 \\
\hline \multirow{6}{*}{$\begin{array}{c}\mathrm{PCB}+ \\
\text { Meio }\end{array}$} & \multirow{6}{*}{$\begin{array}{l}\text { PDMS } \\
(100 \mu \mathrm{m})\end{array}$} & \multirow{6}{*}{1,5} & \multirow{6}{*}{$2,0 \mathrm{~mL}$} & \multirow{6}{*}{1,0} & \multirow{6}{*}{22} & \multirow{6}{*}{250} & \multirow{6}{*}{15} & 1 & 0,04 \\
\hline & & & & & & & & 2 & 0,03 \\
\hline & & & & & & & & 3 & 0,02 \\
\hline & & & & & & & & 4 & 0,01 \\
\hline & & & & & & & & 5 & 0,01 \\
\hline & & & & & & & & 6 & 0,01 \\
\hline
\end{tabular}

${ }^{1}$ Desvio Padrão do Tempo de retenção de cada congenere PCB 10 (Pico 1), PCB 28 (Pico 2), PCB 52 (Pico 3), PCB 153 (Pico 4), PCB 138 (Pico 5) e PCB 180 (Pico 6)

Para a seleção da fibra de extração do PCB considerou-se os seguintes aspectos: a presença de picos finos e bem resolvidos, maior área cromatográfica e melhor reprodutibilidade (RIBANI et al., 2004). Para todas as amostras analisadas verificou-se melhor extração com a aplicação da fibra PDMS/DVB, cujos picos obtidos eram estreitos (Figura 5-3), além da obtenção de adequada reprodutibilidade (menores valores de coeficiente de variação, entre 0,00 e 0,02) e maior área dos picos cromatográficos (entre 2.500.000 e 25.000.000) (Figura 5-4). Assim, a fibra PDMS/DVB foi escolhida como a melhor para a extração e análise cromatográfica do PCB nos ensaios em batelada.

Destaca-se que apesar da fibra PDMS/DVB $(65 \mu \mathrm{m})$ apresentar maior polaridade que a fibra PDMS $(100 \mu \mathrm{m})$, Landín et al. (2001) obtiveram maior eficiência de extração de PCB com a aplicação da fibra composta (PDMS/DVB), semelhante ao obtido neste trabalho. 


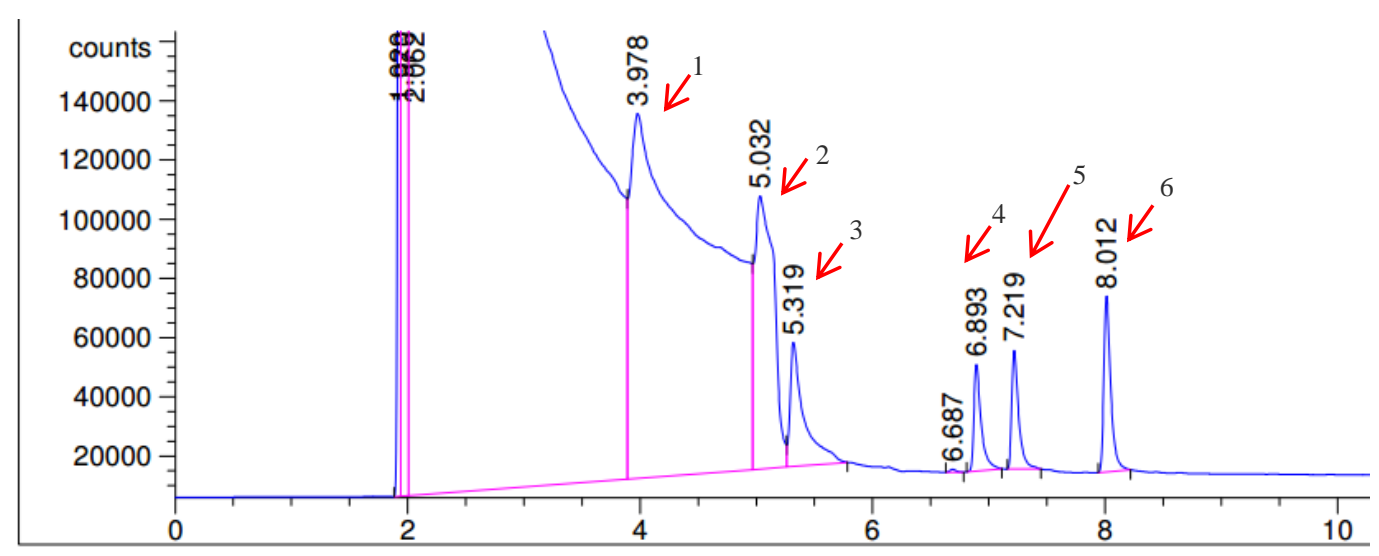

(a)

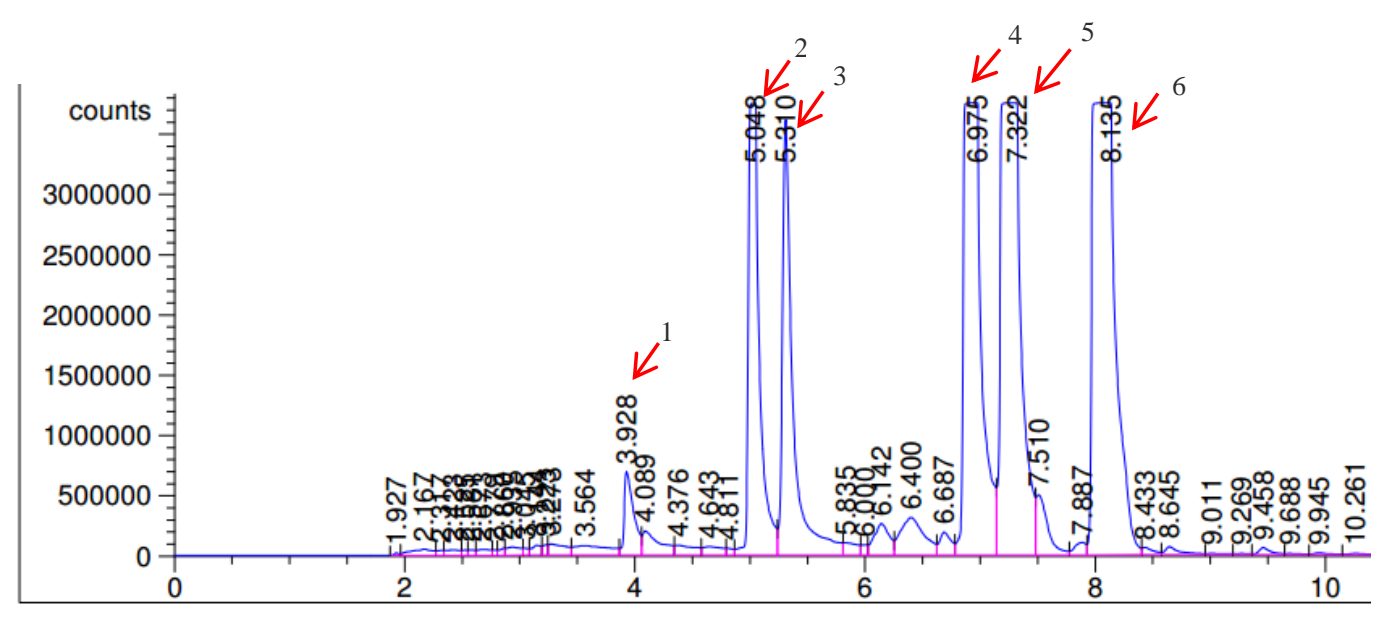

(b)

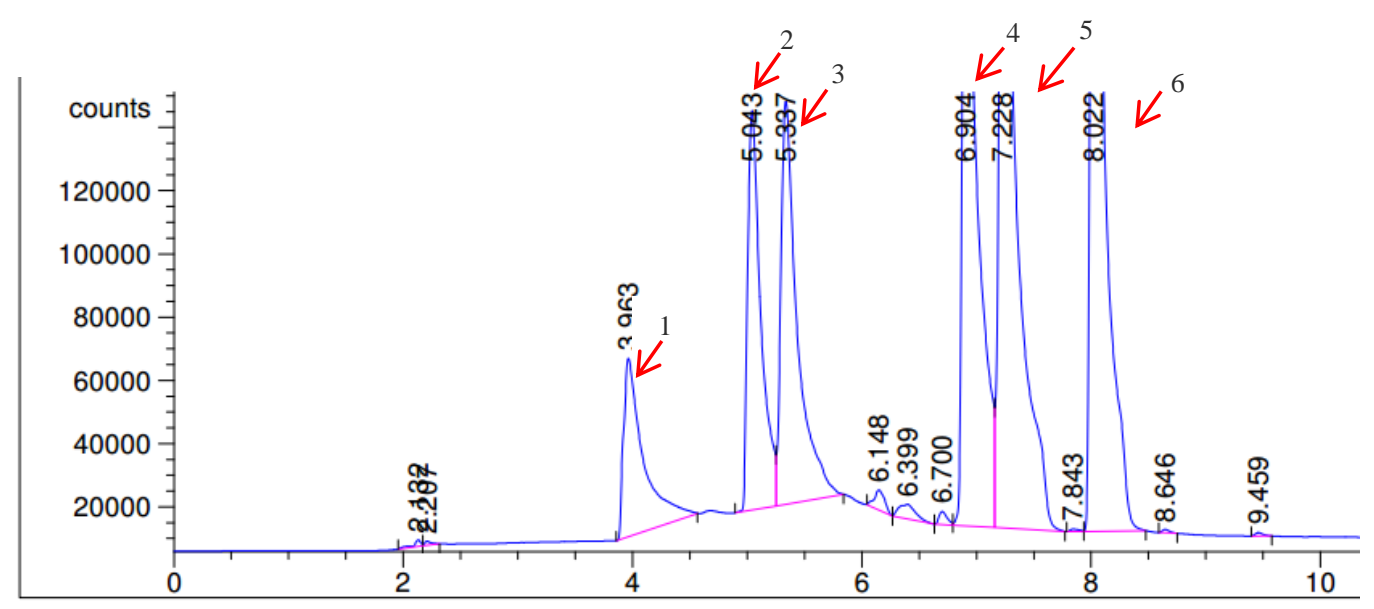

(c)

Figura 5-3 Cromatogramas dos seis congêneres de PCB com diferentes tipos de fibras na extração por meio da técnica de SPME, (a) Carboxen/PDMS, (b) PDMS/DVB e (c) PDMS. PCB 10 (Pico 1), PCB 28 (Pico 2), PCB 52 (Pico 3), PCB 153 (Pico 4), PCB 138 (Pico 5) e PCB 180 (Pico 6). 


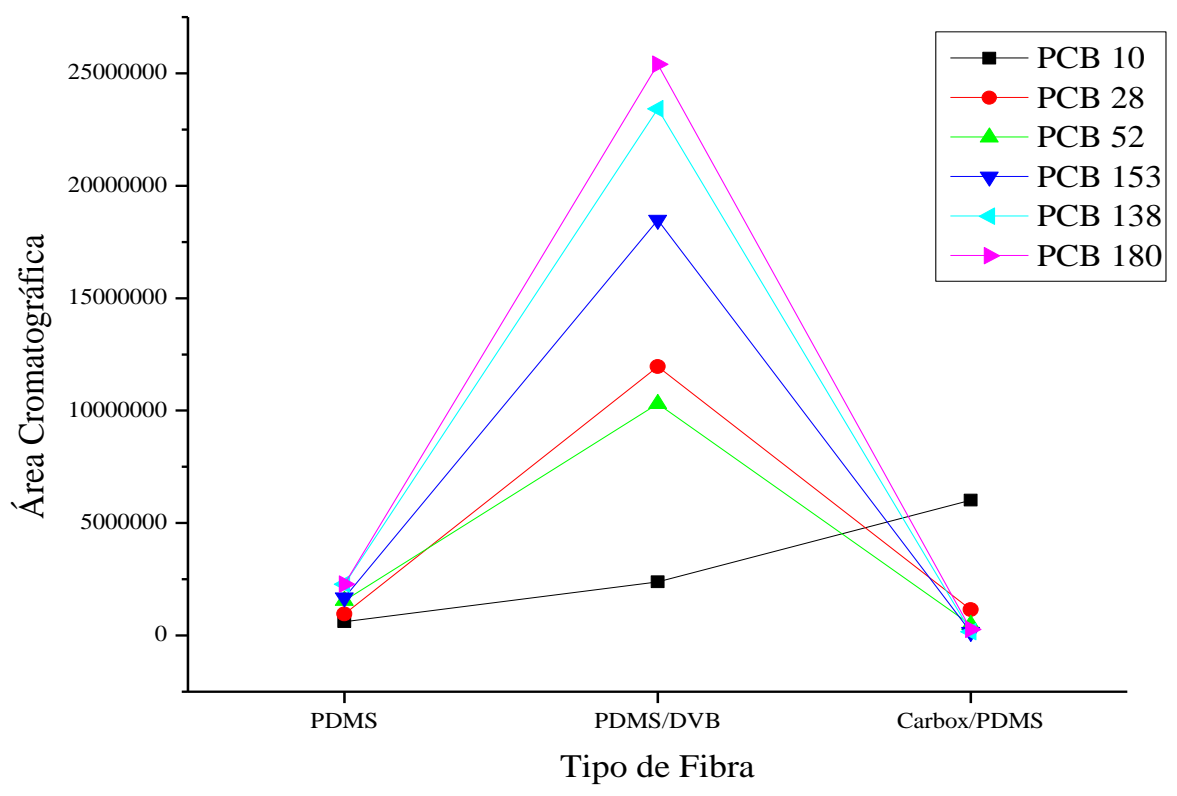

Figura 5-4 Área cromatográfica de cada congênere de PCB com extração sob diferentes tipos de fibras (PDMS, PDMS/DVB e Carbox/PDMS) utilizando a técnica de SPME.

Em relação ao terceiro teste avaliou-se diferentes tempos de extração do PCB para definir aquele mais adequado na aplicação das amostras dos reatores. As condições avaliadas foram 5, 15 e 30 minutos de extração (Tabela 5-4). 
Tabela 5-4 Condição dos testes para a escolha do tempo de extração.

\begin{tabular}{|c|c|c|c|c|c|c|c|c|c|}
\hline Amostra & $\begin{array}{l}\text { Fibra de } \\
\text { SMPE }\end{array}$ & $\begin{array}{l}\text { Concentração } \\
\text { PCB (mg/L) }\end{array}$ & $\begin{array}{c}\text { Volume de } \\
\text { amostra (mL) }\end{array}$ & $\begin{array}{l}\mathrm{NaCl} \\
(\mathrm{g})\end{array}$ & $\begin{array}{c}\text { Temperatura } \\
\text { Extração }\left({ }^{\circ} \mathrm{C}\right)\end{array}$ & $\begin{array}{l}\text { Temperatura } \\
\text { de dessorção } \\
\left({ }^{\circ} \mathrm{C}\right)\end{array}$ & $\begin{array}{l}\text { Tempo de } \\
\text { extração } \\
\text { (min) }\end{array}$ & \multicolumn{2}{|c|}{$\begin{array}{c}\text { Desvio padrão } \\
\text { Tempo } \\
\text { retenção }^{1}\end{array}$} \\
\hline \multirow{6}{*}{$\begin{array}{c}\mathrm{PCB}+ \\
\text { Meio }\end{array}$} & \multirow{6}{*}{$\begin{array}{l}\text { PDMS/DVB } \\
\quad(65 \mu \mathrm{m})\end{array}$} & \multirow{6}{*}{0,09} & \multirow{6}{*}{2,0} & \multirow{6}{*}{1,0} & \multirow{6}{*}{22} & \multirow{6}{*}{250} & \multirow{6}{*}{5} & 1 & 0,01 \\
\hline & & & & & & & & 2 & 0,01 \\
\hline & & & & & & & & 3 & 0,01 \\
\hline & & & & & & & & 4 & 0,00 \\
\hline & & & & & & & & 5 & 0,01 \\
\hline & & & & & & & & 6 & 0,00 \\
\hline \multirow{6}{*}{$\begin{array}{c}\mathrm{PCB}+ \\
\text { Meio }\end{array}$} & \multirow{6}{*}{$\begin{array}{l}\text { PDMS/DVB } \\
\quad(65 \mu \mathrm{m})\end{array}$} & \multirow{6}{*}{1,5} & \multirow{6}{*}{2,0} & \multirow{6}{*}{1,0} & \multirow{6}{*}{22} & \multirow{6}{*}{250} & \multirow{6}{*}{5} & 1 & 0,26 \\
\hline & & & & & & & & 2 & 0,11 \\
\hline & & & & & & & & 3 & 0,06 \\
\hline & & & & & & & & 4 & 0,13 \\
\hline & & & & & & & & 5 & 0,13 \\
\hline & & & & & & & & 6 & 0,15 \\
\hline \multirow{6}{*}{$\begin{array}{c}\mathrm{PCB}+ \\
\text { Meio }\end{array}$} & \multirow{6}{*}{$\begin{array}{l}\text { PDMS/DVB } \\
\quad(65 \mu \mathrm{m})\end{array}$} & \multirow{6}{*}{0,09} & \multirow{6}{*}{2,0} & \multirow{6}{*}{1,0} & \multirow{6}{*}{22} & \multirow{6}{*}{250} & \multirow{6}{*}{15} & 1 & 0,02 \\
\hline & & & & & & & & 2 & 0,02 \\
\hline & & & & & & & & 3 & 0,02 \\
\hline & & & & & & & & 4 & 0,02 \\
\hline & & & & & & & & 5 & 0,03 \\
\hline & & & & & & & & 6 & 0,03 \\
\hline \multirow{6}{*}{$\begin{array}{c}\mathrm{PCB}+ \\
\text { Meio }\end{array}$} & & & & & & & & 1 & 0,01 \\
\hline & & & & & & & & 2 & 0,02 \\
\hline & PDMS/DVB & 15 & 20 & & & & & 3 & 0,02 \\
\hline & $(65 \mu \mathrm{m})$ & 1,5 & 2,0 & 1,0 & 22 & 250 & 15 & 4 & 0,05 \\
\hline & & & & & & & & 5 & 0,00 \\
\hline & & & & & & & & 6 & 0,00 \\
\hline & & & & & & & & 1 & 0,02 \\
\hline & & & & & & & & 2 & 0,02 \\
\hline $\mathrm{PCB}+$ & PDMS/DVB & & & & & & & 3 & 0,02 \\
\hline Meio & $(65 \mu \mathrm{m})$ & 0,09 & 2,0 & 1,0 & 22 & 250 & 30 & 4 & 0,01 \\
\hline & & & & & & & & 5 & 0,01 \\
\hline & & & & & & & & 6 & 0,01 \\
\hline & & & & & & & & $\overline{1}$ & 0,06 \\
\hline & & & & & & & & 2 & 0,05 \\
\hline $\mathrm{PCB}+$ & PDMS/DVB & 15 & 20 & 10 & 22 & 250 & 30 & 3 & 0,05 \\
\hline Meio & $(65 \mu \mathrm{m})$ & 1,5 & 2,0 & 1,0 & 22 & 250 & 30 & 4 & 0,04 \\
\hline & & & & & & & & 5 & 0,04 \\
\hline & & & & & & & & 6 & 0,04 \\
\hline
\end{tabular}

${ }^{1}$ Desvio Padrão do Tempo de retenção de cada congenere PCB 10 (Pico 1), PCB 28 (Pico 2), PCB 52 (Pico 3), PCB 153 (Pico 4), PCB 138 (Pico 5) e PCB 180 (Pico 6)

Verificou-se para os diferentes tempos de extração do PCB maior coeficiente de variação para o tempo de extração de 5 e 30 minutos, entre 0,00 e 0,26 e entre 0,01 e 0,06 , respectivamente. Ademais, em 5 min e 30 min obteve-se menores áreas cromatográficas de cada pico de PCB, entre 500.000 e 1.000 .000 e entre 500.000 e 6.000 .000 , respectivamente (Figura 5-5). 


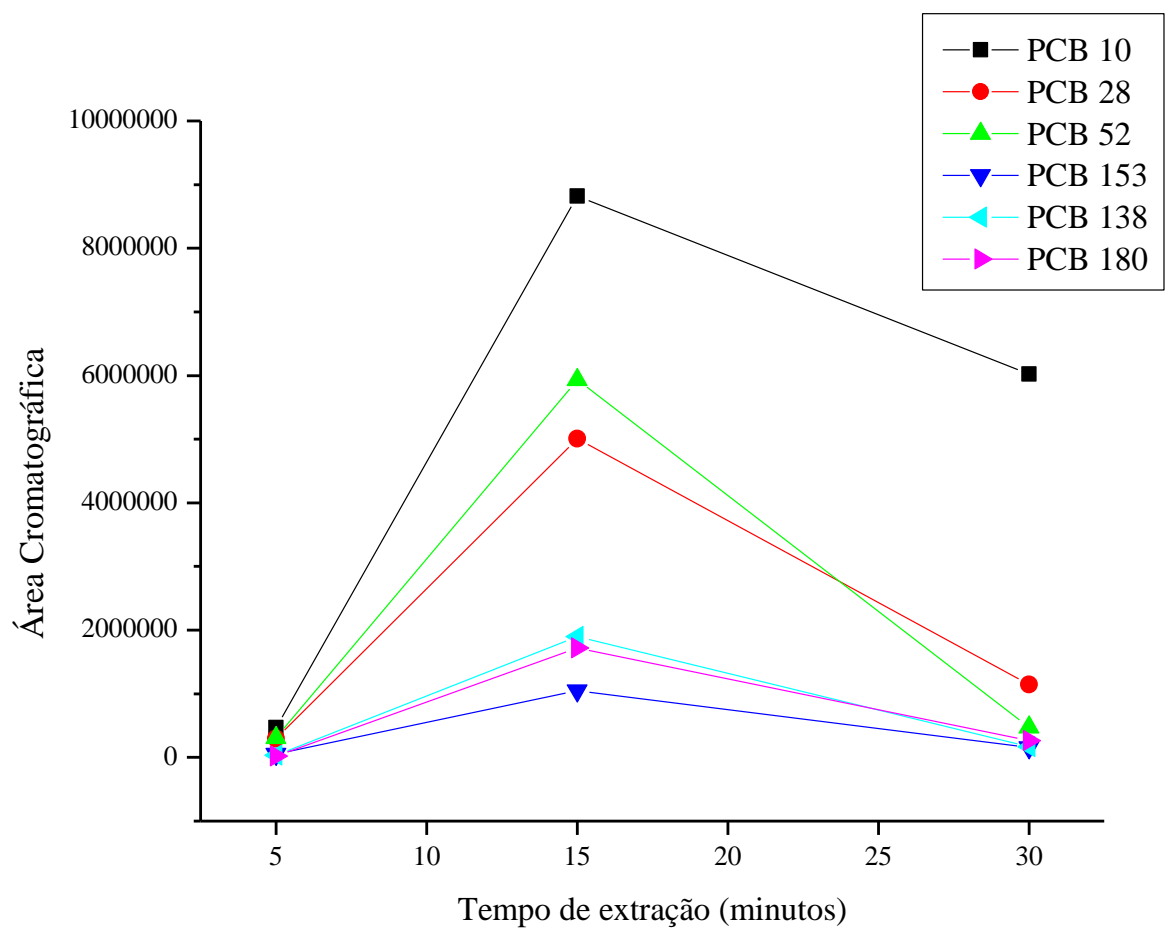

Figura 5-5 Área cromatográfica de cada congênere de PCB $\left(1,5\right.$ mg.L $\left.\mathrm{L}^{-1}\right)$ em 5, 15 e 30 minutos de extração com a técnica de SPME.

Para 5 minutos de extração foi observado cromatogramas com perfis de linha de base com ruído e picos menos definidos. Este perfil pode estar relacionado com a falta de equilíbrio entre o PCB da amostra e a fibra (Figura 5-6).

Tempo reduzido de extração, no caso 15 minutos, é um tempo ótimo de utilização da técnica de SPME por assegurar que no final da corrida do cromatógrafo gasoso (16 minutos) e do tempo de esfriamento do forno, a próxima amostra está pronta para injeção (LLOMPART; LI; FINGAS, 1998; ALMEIDA; BOAS, 2004). Assim, verificou-se que 15 minutos de extração foi mais adequado, sendo obtido menor coeficiente de variação e maiores áreas cromatográficas, viabilizando amostragem com maior eficiência e reprodutibilidade. 


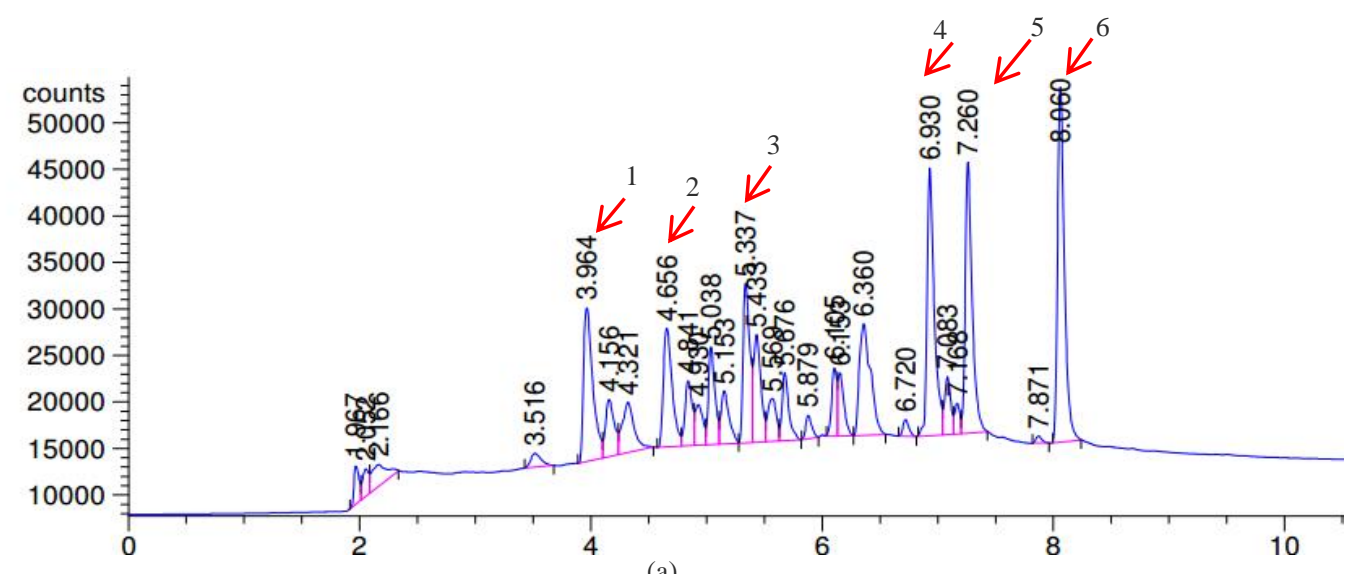

(a)
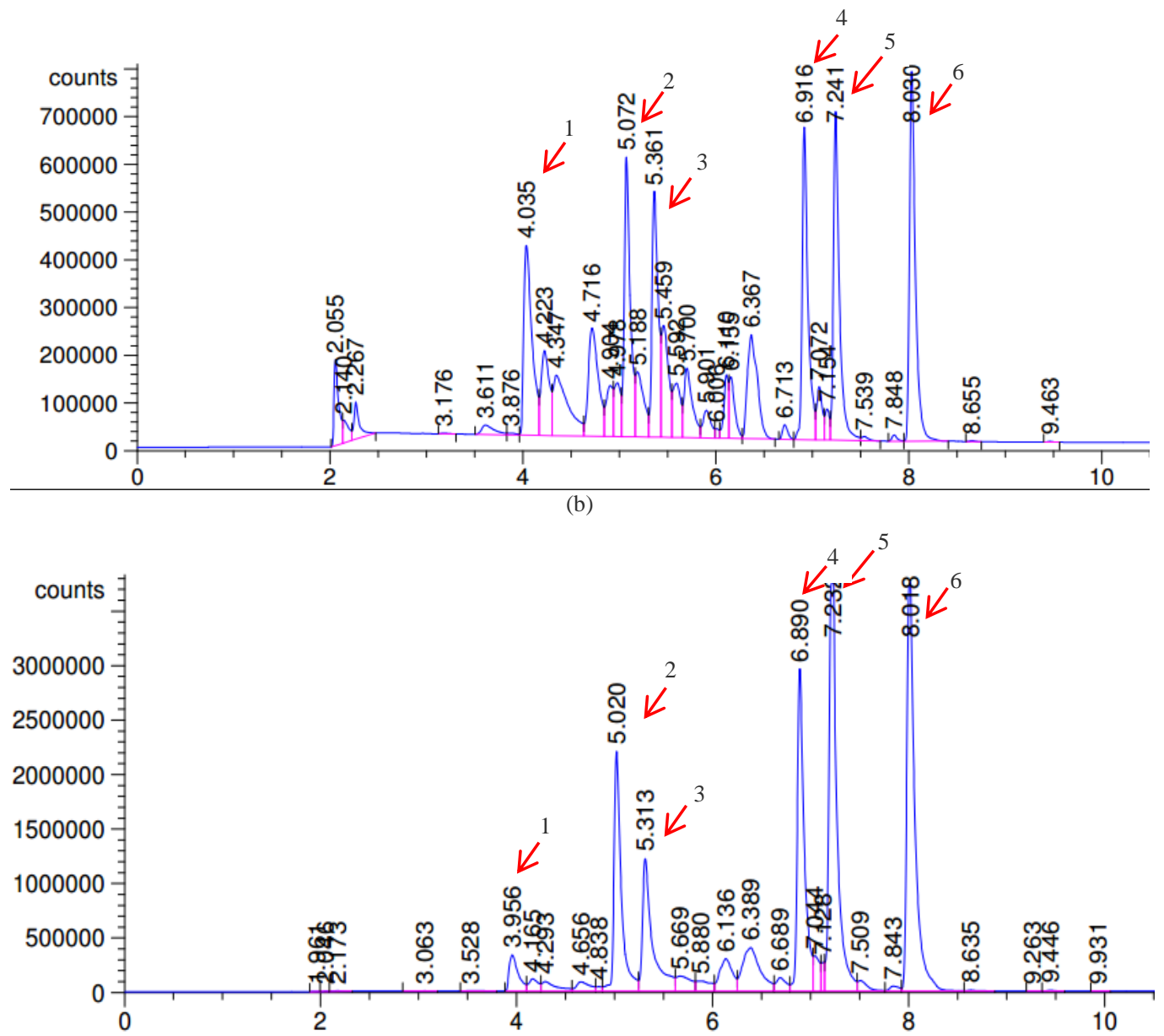

(c)

Figura 5-6 Perfil cromatográfico de congêneres de PCB em diferentes tempos de extração. (a) perfil cromatográfico para 5 minutos com 1,5 mg. $\mathrm{L}^{-1}$, (b) perfil cromatográfico para 15 minutos com 1,5 mg.. $\mathrm{L}^{-1}$, (c) perfil cromatográfico para 30 minutos com 1,5 mg.L-1 . PCB 10 (Pico 1), PCB 28 (Pico 2), PCB 52 (Pico 3), PCB 153 (Pico 4), PCB 138 (Pico 5) e PCB 180 (Pico 6).

Verificou-se para diferentes temperaturas de dessorção, $210^{\circ} \mathrm{C}, 250^{\circ} \mathrm{C}$ e $280^{\circ} \mathrm{C}$ (Tabela 5-5) mudanças no coeficiente de variação, na linha de base, como também no desvio padrão do tempo de retenção cromatográfica. $\mathrm{O}$ desvio padrão do tempo de retenção calculado foi alto em $210^{\circ}$ (de 0,23 a 0,38). Devido a isso, tornou-se inviável a utilização desta temperatura, já que o tempo de retenção é um componente imprescindível na validação do método de extração. 
Tabela 5-5 Condição dos testes para a escolha da temperatura de dessorção de extração do PCB com a técnica de SPME.

\begin{tabular}{|c|c|c|c|c|c|c|c|c|c|}
\hline Amostra & $\begin{array}{l}\text { Fibra de } \\
\text { SMPE }\end{array}$ & $\begin{array}{c}\text { Concentração } \\
\text { PCB }(\mathrm{mg} / \mathrm{L})\end{array}$ & $\begin{array}{c}\text { Volume de } \\
\text { amostra (mL) }\end{array}$ & $\begin{array}{l}\mathrm{NaCl} \\
(\mathrm{g})\end{array}$ & $\begin{array}{c}\text { Temperatura } \\
\text { Extração }\left({ }^{\circ} \mathrm{C}\right)\end{array}$ & $\begin{array}{c}\text { Temperatura } \\
\text { de dessorção } \\
\left({ }^{\circ} \mathrm{C}\right)\end{array}$ & $\begin{array}{c}\text { Tempo de } \\
\text { extração } \\
(\mathrm{min})\end{array}$ & \multicolumn{2}{|c|}{$\begin{array}{c}\text { Desvio padrão } \\
\text { Tempo } \\
\text { retenção }^{1}\end{array}$} \\
\hline \multirow{6}{*}{$\begin{array}{c}\mathrm{PCB}+ \\
\text { Meio }\end{array}$} & \multirow{6}{*}{$\begin{array}{l}\text { PDMS/DVB } \\
\quad(65 \mu \mathrm{m})\end{array}$} & \multirow{6}{*}{1,5} & \multirow{6}{*}{2,0} & \multirow{6}{*}{1,0} & \multirow{6}{*}{22} & \multirow{6}{*}{210} & \multirow{6}{*}{15} & 1 & 0,23 \\
\hline & & & & & & & & 2 & 0,26 \\
\hline & & & & & & & & 3 & 0,27 \\
\hline & & & & & & & & 4 & 0,32 \\
\hline & & & & & & & & 5 & 0,34 \\
\hline & & & & & & & & 6 & 0,38 \\
\hline \multirow{6}{*}{$\begin{array}{c}\mathrm{PCB}+ \\
\text { Meio }\end{array}$} & \multirow{6}{*}{$\begin{array}{c}\text { PDMS/DVB } \\
(65 \mu \mathrm{m})\end{array}$} & \multirow{6}{*}{1,5} & \multirow{6}{*}{2,0} & \multirow{6}{*}{1,0} & \multirow{6}{*}{22} & \multirow{6}{*}{250} & \multirow{6}{*}{15} & 1 & 0,01 \\
\hline & & & & & & & & 2 & 0,02 \\
\hline & & & & & & & & 3 & 0,02 \\
\hline & & & & & & & & 4 & 0,00 \\
\hline & & & & & & & & 5 & 0,00 \\
\hline & & & & & & & & 6 & 0,00 \\
\hline \multirow{6}{*}{$\begin{array}{c}\text { PCB + } \\
\text { Meio }\end{array}$} & \multirow{6}{*}{$\begin{array}{c}\text { PDMS/DVB } \\
(65 \mu \mathrm{m})\end{array}$} & \multirow{6}{*}{1,5} & \multirow{6}{*}{2,0} & \multirow{6}{*}{1,0} & \multirow{6}{*}{22} & \multirow{6}{*}{280} & \multirow{6}{*}{15} & 1 & 0,03 \\
\hline & & & & & & & & 2 & 0,02 \\
\hline & & & & & & & & 3 & 0,02 \\
\hline & & & & & & & & 4 & 0,01 \\
\hline & & & & & & & & 5 & 0,01 \\
\hline & & & & & & & & 6 & 0,01 \\
\hline
\end{tabular}

${ }^{1}$ Desvio Padrão do Tempo de retenção de cada congenere PCB 10 (Pico 1), PCB 28 (Pico 2), PCB 52 (Pico 3), PCB 153 (Pico 4), PCB 138 (Pico 5) e PCB 180 (Pico 6)

Entretanto, quando se comparou os picos cromatográficos (Figura 5-7), nenhuma alteração foi observada em $250^{\circ} \mathrm{C}$ e $280^{\circ} \mathrm{C}$. Em $210^{\circ} \mathrm{C}$ obteve-se picos com ruído e indefinidos, por conseguinte, pode-se inferir em menor eficiência na extração e análise do analito, possivelmente pela dessorção incompleta em temperatura mais baixa, no caso $210^{\circ} \mathrm{C}$. 


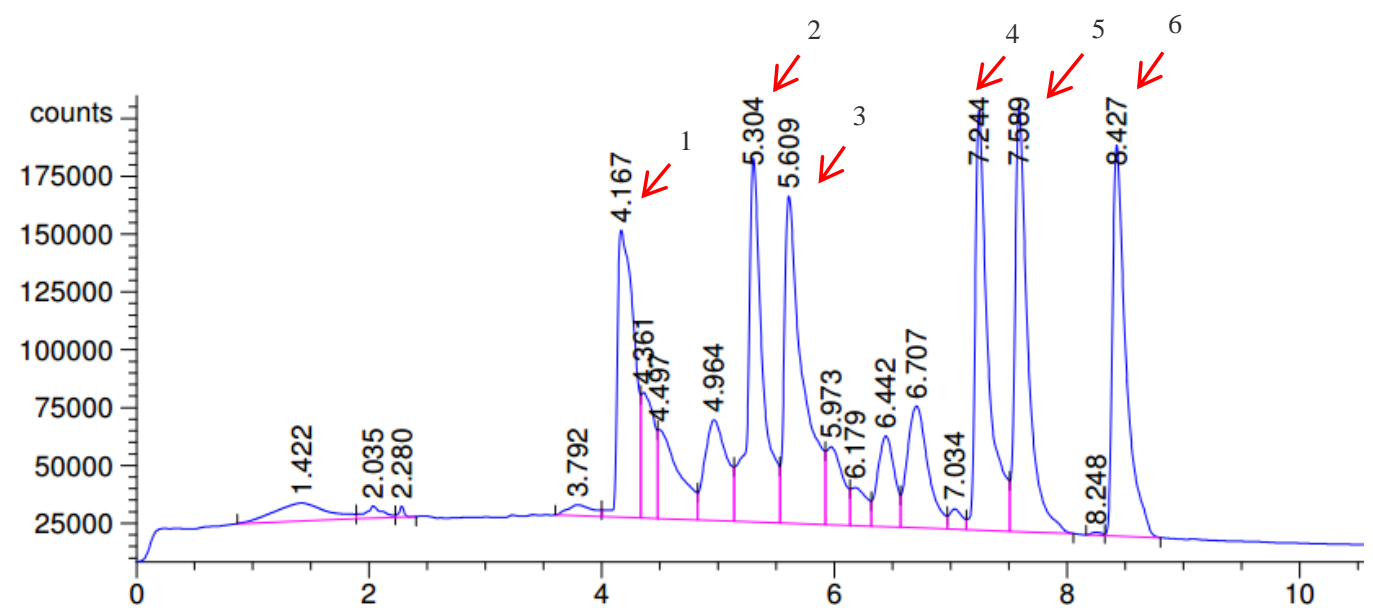

(a)

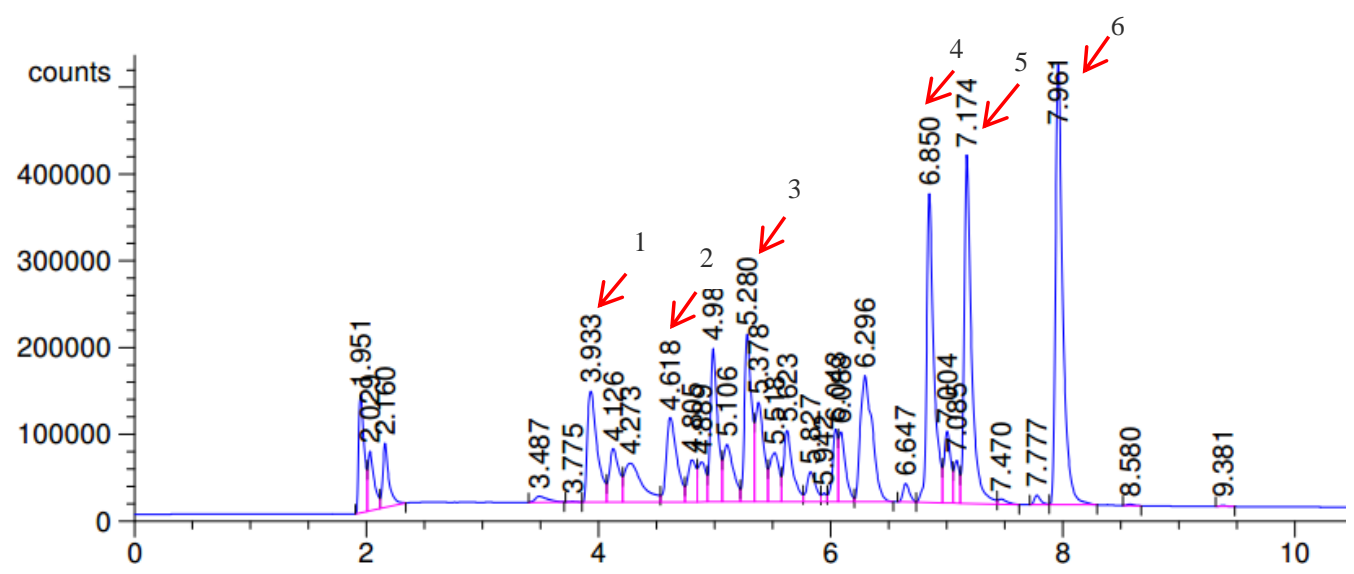

(b)

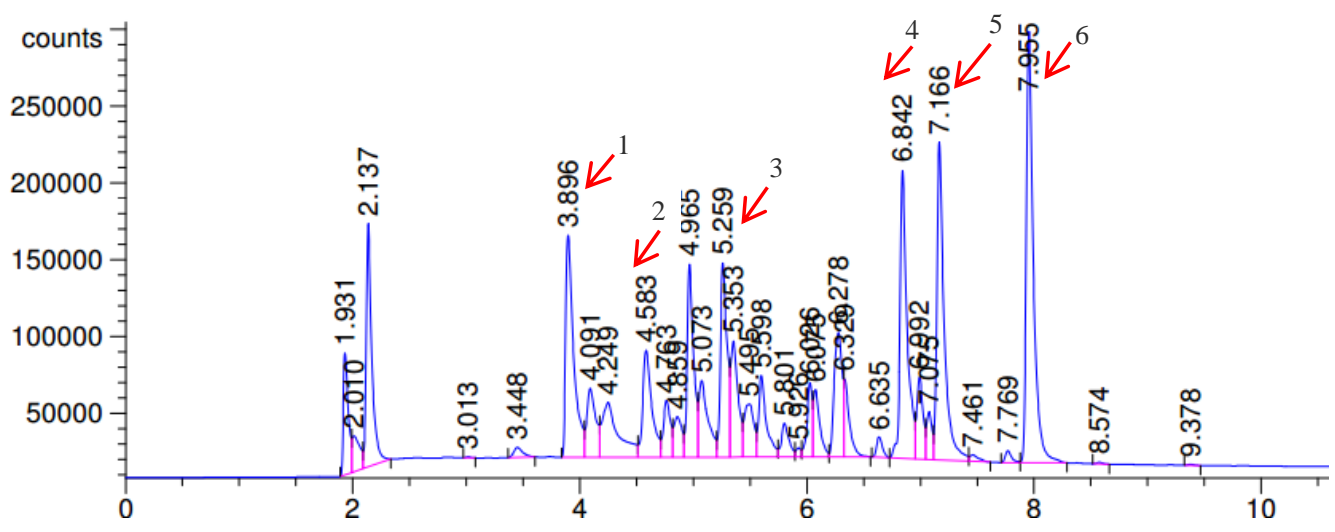

(c)

Figura 5-7 Perfis cromatográficos em diferentes temperaturas de dessorção: (a) $210^{\circ} \mathrm{C}$, (b) $250^{\circ} \mathrm{C} \mathrm{e} \mathrm{(c)} 280^{\circ} \mathrm{C}$ com 1,5 mg.L L $^{-1}$ de PCB na extração pela técnica de SPME. PCB 10 (Pico 1), PCB 28 (Pico 2), PCB 52 (Pico 3), PCB 153 (Pico 4), PCB 138 (Pico 5) e PCB 180 (Pico 6). 
Em $250^{\circ} \mathrm{C}$ (1,5 mg. $\mathrm{L}^{-1}$ de $\left.\mathrm{PCB}\right)$ foram encontrados menores desvios padrões do tempo de retenção (entre 0,00 e 0,02), resultando em maior estabilidade. Entretanto, nesta temperatura foi encontrado menores áreas cromatográficas, entre 500.000 e 6.000 .000 (Figura 5-8).

Por sua vez, em $280^{\circ} \mathrm{C}$ excedeu a temperatura máxima de $270^{\circ} \mathrm{C}$ estabelecida pelo fabricante da fibra PDMS/DVB e, sob tais condições, pode ocasionar a degradação e liberação de compostos da própria fibra, mascarando os picos provenientes do $\mathrm{PCB}$. Assim, neste estudo a temperatura estabelecida para a extração do PCB foi de $250^{\circ} \mathrm{C}$.

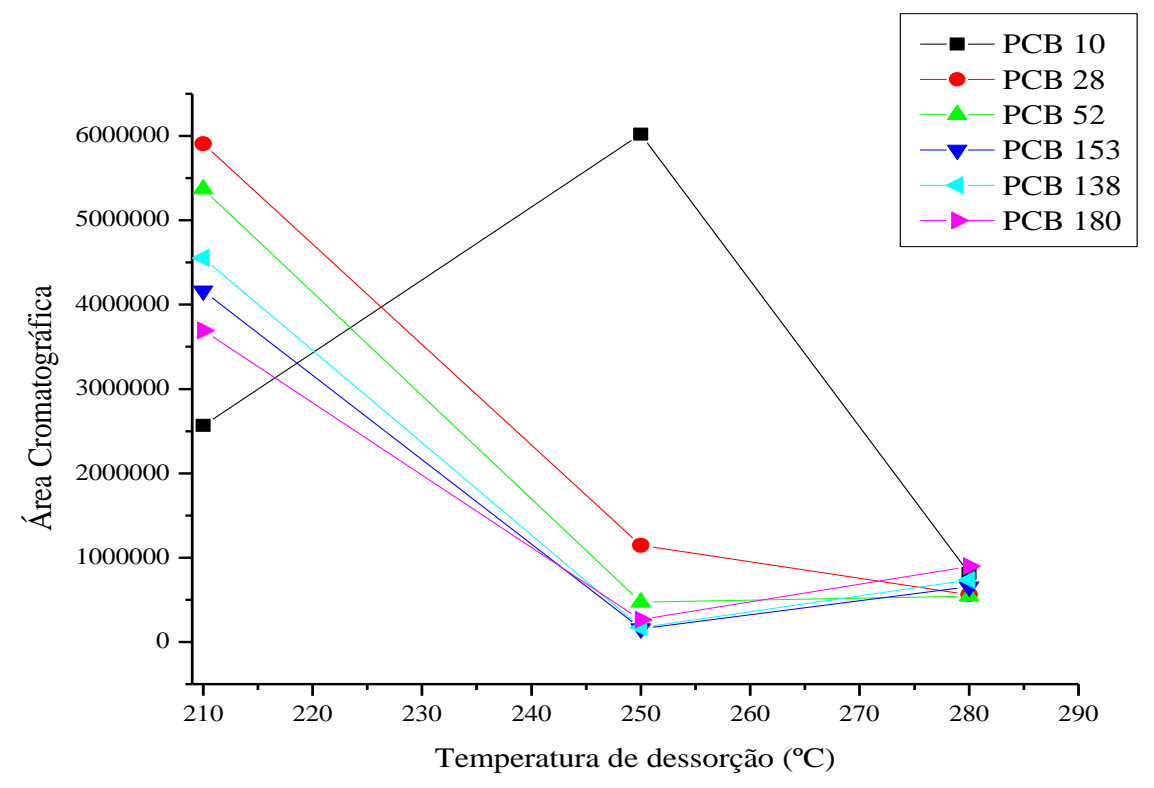

Figura 5-8 Área cromatográfica referente a dessorção a $210^{\circ} \mathrm{C}, 250^{\circ} \mathrm{C}$ e $280^{\circ} \mathrm{C}$ para 1,5 mg.L $\mathrm{L}^{-1}$ de $\mathrm{PCB}$.

No penúltimo teste avaliaram-se diferentes volumes amostrais na extração do PCB pela técnica de SPME. As condições avaliadas foram 2,0 mL, 2,5 mL e 3,0 mL de meio liquido (Tabela 5-6).

Para o teste com diferentes volumes amostrais $(2,0 \mathrm{~mL}, 2,5 \mathrm{~mL}$ e $3,0 \mathrm{~mL})$ não foi encontrado diferenças no desvio padrão do tempo de retenção cromatográfica, todos abaixo de 0,06 (Tabela 5-6). Ademais, quando avaliou-se as áreas cromatográficas de cada congênere de PCB (Figura 5-9) observouse maiores áreas cromatográficas com 2,0 mL de amostra, sendo 1.000 .000 e 5.000 .000 para 0,09 mg.L${ }^{1}$ de PCB e entre 12.500 .000 e 22.500 .000 para $1,5 \mathrm{mg} . \mathrm{L}^{-1}$ de PCB. Para $2,5 \mathrm{~mL}$ de amostra observouse picos entre 500.000 e 4.000 .000 para 0,09 mg.L $\mathrm{L}^{-1}$ de PCB e entre 100.000 e 500.000 para $1,5 \mathrm{mg} . \mathrm{L}^{-1}$ de PCB. Para as amostras com 3,0 mL observou-se picos entre 500.000 e 1.000 .000 para 0,09 mg.. $\mathrm{L}^{-1}$ de PCB, e entre 100.000 e 500.000 para 1,5 mg. $\mathrm{L}^{-1}$ de PCB.

A extração por meio de SPME envolve interações entre a fase líquida, gasosa e o revestimento da fibra. O efeito do volume amostral na cinética e termodinâmica da extração é muito complexa e dependente da constante de partição (GÓRECKI, 1997; GÓRECKI; KHALED; PAWLISZYN, 1998). Landín et al. (2001) confirmaram que a apliacação de maior volume amostral foi adequada para obtenção de maior quantidade de PCB extraído. Todavia, por meio da técnica de SPME, pode-se afirmar que o 
acréscimo no volume amostral atingindo o limite de adsorção da fibra e de partição do analito no headspace não favorece a maior extração do analito (GÓRECKI, 1997; GÓRECKI; KHALED; PAWLISZYN, 1998), exemplificado pela área cromatográfica para amostras com 2,0 mL (entre 1.000 .000 e 5.000.000). Desse modo, com base nessas informações optou-se no presente estudo em utilizar menor volume $(2,0 \mathrm{~mL})$ na extração dos seis congêneres de PCB.

Tabela 5-6 Condição dos testes para a escolha do volume amostral ideal na extração de PCB utilizando o SPME.

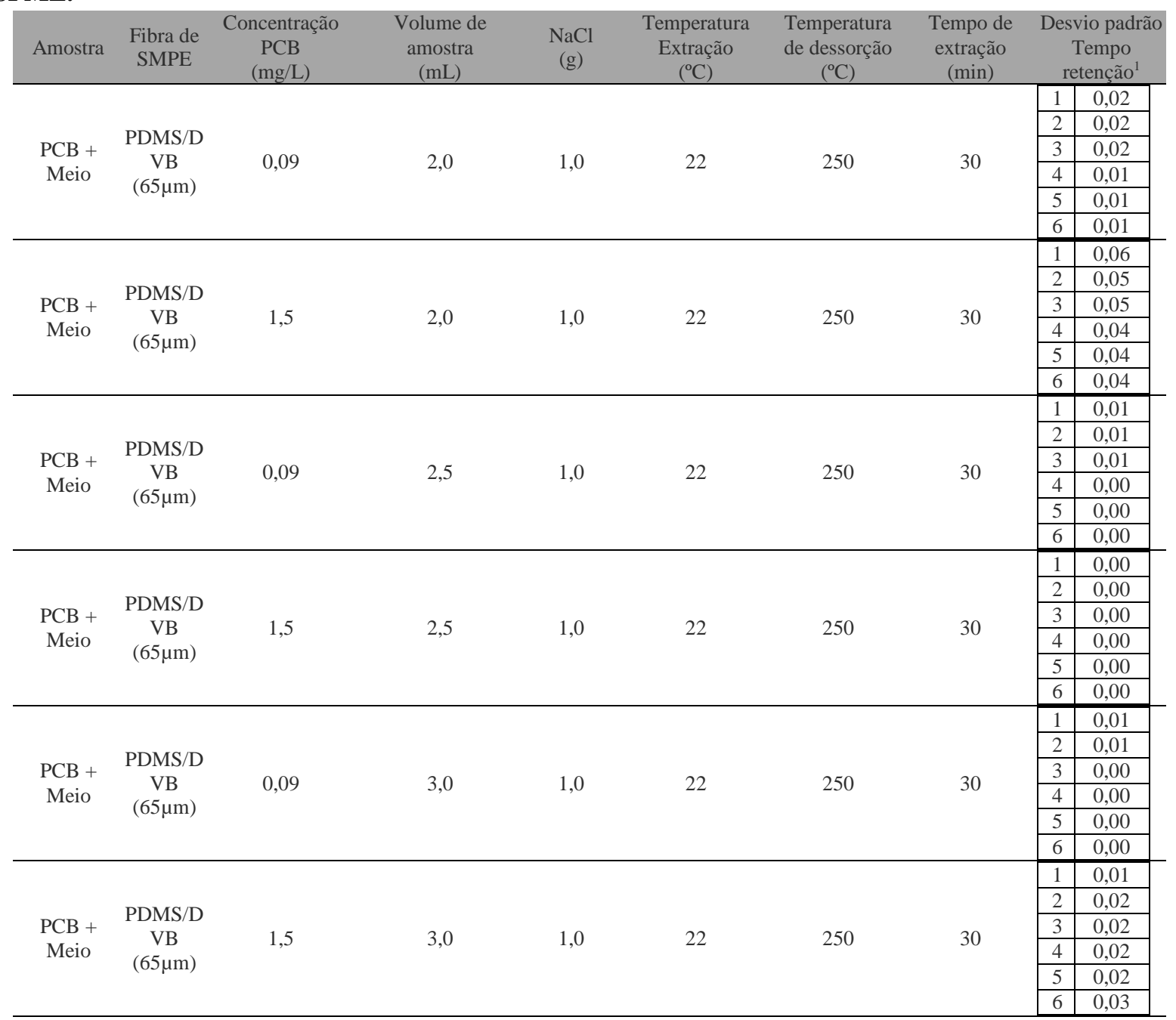

\footnotetext{
${ }^{1}$ Desvio Padrão do Tempo de retenção de cada congenere PCB 10 (Pico 1), PCB 28 (Pico 2), PCB 52 (Pico 3), PCB 153 (Pico 4), PCB 138 (Pico 5) e PCB 180 (Pico 6)
} 


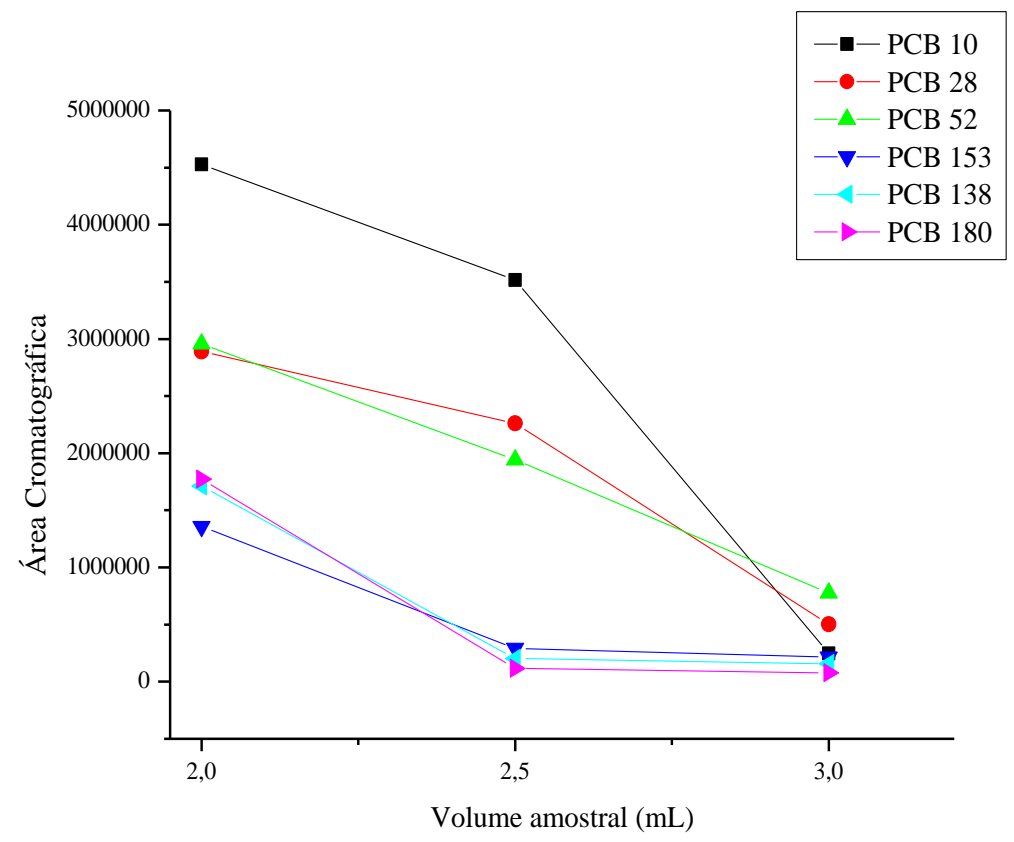

(a)

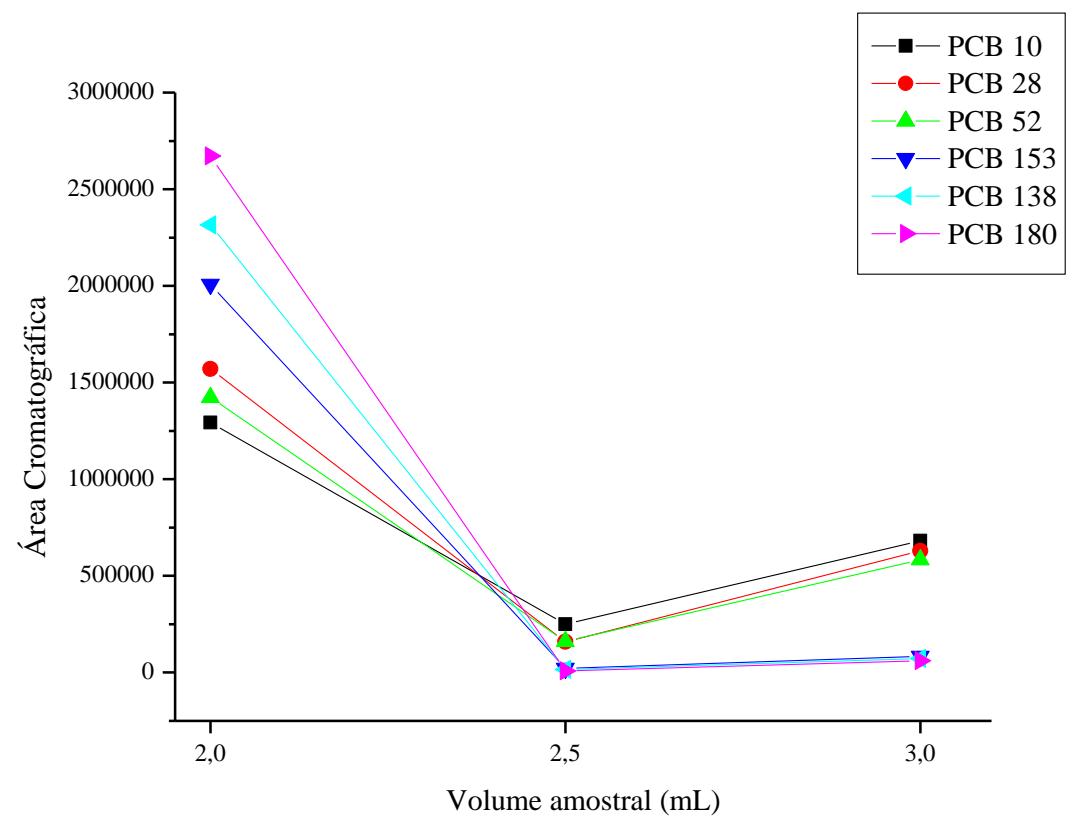

(b)

Figura 5-9 Área cromatográfica de cada congênere de PCB extraído com a técnica de SPME com diferentes volumes amostrais $(2,0,2,5$ e 3,0 mL): (a) área cromatográfica de cada congênere nos diferentes volumes amostrais para $0,09{\mathrm{mg} . \mathrm{L}^{-1}}^{-1 e} \mathrm{PCB}$, (b) área cromatográfica de cada congênere nos diferentes volumes amostrais para 1,5 mg. $\mathrm{L}^{-1}$ de PCB. 
Por fim, testou-se a utilização de octacloronaftaleno como padrão interno para a extração por meio da técnica de SPME (0,5 mg.L $\mathrm{L}^{-1}, 0,8 \mathrm{mg} \cdot \mathrm{L}^{-1}$ e 3,0 $\left.\mathrm{mg} \mathrm{L}^{-1}\right)$ (Tabela 5-7). Após preparar as soluções adicionou-se a cada uma delas uma concentração conhecida de padrão interno (octacloronaftaleno) cuja estrutura química é semelhante à dos analitos em estudo com tempo de retenção análogo (ADORNO, 2013).

Tabela 5-7 Condição dos testes da utilização de padrão interno na extração do PCB com a técnica de SPME.

\begin{tabular}{|c|c|c|c|c|c|c|c|c|c|c|}
\hline Amostra & $\begin{array}{c}\text { Fibra de } \\
\text { SMPE }\end{array}$ & $\begin{array}{l}\text { Concentração } \\
\text { PCB }\left(\mathrm{mg} \cdot \mathrm{L}^{-1}\right)\end{array}$ & $\begin{array}{l}\text { Volume } \\
\text { amostra } \\
(\mathrm{mL})\end{array}$ & $\begin{array}{l}\mathrm{NaCl} \\
(\mathrm{g})\end{array}$ & $\begin{array}{l}\text { Temp. } \\
\text { Extração } \\
\left({ }^{\circ} \mathrm{C}\right)\end{array}$ & $\begin{array}{l}\text { Temp. } \\
\text { dessorção } \\
\left({ }^{\circ} \mathrm{C}\right)\end{array}$ & $\begin{array}{l}\text { Tempo } \\
\text { extração } \\
(\mathrm{min})\end{array}$ & $\begin{array}{c}\text { Padrão Interno - } \\
\text { Octacloronaftaleno } \\
\left(\mathrm{mg} \cdot \mathrm{L}^{-1}\right)\end{array}$ & \multicolumn{2}{|c|}{$\begin{array}{l}\text { Desvio } \\
\text { padrão } \\
\text { Tempo } \\
\text { retenção }^{1}\end{array}$} \\
\hline \multirow{6}{*}{$\begin{array}{c}\mathrm{PCB}+ \\
\text { Meio }\end{array}$} & \multirow{6}{*}{$\begin{array}{l}\text { PDMS/ } \\
\text { DVB } \\
(65 \mu \mathrm{m})\end{array}$} & \multirow{6}{*}{0,09} & \multirow{6}{*}{$2,0 \mathrm{~mL}$} & \multirow{6}{*}{1,0} & \multirow{6}{*}{22} & \multirow{6}{*}{250} & \multirow{6}{*}{15} & \multirow{6}{*}{0,5} & 1 & 0,04 \\
\hline & & & & & & & & & 2 & 0,05 \\
\hline & & & & & & & & & 3 & 0,05 \\
\hline & & & & & & & & & 4 & 0,03 \\
\hline & & & & & & & & & 5 & 0,03 \\
\hline & & & & & & & & & 6 & 0,03 \\
\hline \multirow{6}{*}{$\begin{array}{l}\mathrm{PCB}+ \\
\text { Meio }\end{array}$} & \multirow{6}{*}{$\begin{array}{l}\text { PDMS/ } \\
\text { DVB } \\
(65 \mu \mathrm{m})\end{array}$} & \multirow{6}{*}{0,09} & \multirow{6}{*}{$2,0 \mathrm{~mL}$} & \multirow{6}{*}{1,0} & \multirow{6}{*}{22} & \multirow{6}{*}{250} & \multirow{6}{*}{15} & \multirow{6}{*}{0,8} & 1 & 0,04 \\
\hline & & & & & & & & & 2 & 0,03 \\
\hline & & & & & & & & & 3 & 0,02 \\
\hline & & & & & & & & & 4 & 0,01 \\
\hline & & & & & & & & & 5 & 0,01 \\
\hline & & & & & & & & & 6 & 0,01 \\
\hline \multirow{6}{*}{$\begin{array}{c}\mathrm{PCB}+ \\
\text { Meio }\end{array}$} & \multirow{6}{*}{$\begin{array}{l}\text { PDMS/ } \\
\text { DVB } \\
(65 \mu \mathrm{m})\end{array}$} & \multirow{6}{*}{0,09} & \multirow{6}{*}{$2,0 \mathrm{~mL}$} & \multirow{6}{*}{1,0} & \multirow{6}{*}{22} & \multirow{6}{*}{250} & \multirow{6}{*}{15} & \multirow{6}{*}{3,0} & 1 & 0,01 \\
\hline & & & & & & & & & 2 & 0,02 \\
\hline & & & & & & & & & 3 & 0,02 \\
\hline & & & & & & & & & 4 & 0,05 \\
\hline & & & & & & & & & 5 & 0,06 \\
\hline & & & & & & & & & 6 & 0,07 \\
\hline \multirow{6}{*}{ Água } & \multirow{6}{*}{$\begin{array}{l}\text { PDMS/ } \\
\text { DVB } \\
(65 \mu \mathrm{m})\end{array}$} & \multirow{6}{*}{0} & & & & & & & 1 & 0,02 \\
\hline & & & & & & & & & 2 & 0,01 \\
\hline & & & $20 \mathrm{mI}$ & 10 & 22 & 250 & 15 & 08 & 3 & 0,01 \\
\hline & & & $2,0 \mathrm{~mL}$ & 1,0 & 22 & 250 & 15 & 0,8 & 4 & 0,00 \\
\hline & & & & & & & & & 5 & 0,00 \\
\hline & & & & & & & & & 6 & 0,00 \\
\hline
\end{tabular}
PCB 138 (Pico 5) e PCB 180 (Pico 6)

Entretanto, encontrar um padrão interno que se ajuste perfeitamente a matrizes complexas é um trabalho árduo e que pode comprometer a facilidade analítica do método (OUYANG; PAWLISZYN, 2008). Especificamente, nesse estudo verificou-se para o octacloronaftaleno tempo de retenção conflitante e igual ao do PCB 180 (7,9 minutos) e, como a substância escolhida como padrão interno deve ter estrutura química semelhante à dos analitos em estudo, ser estável e não interferir na análise (LIGIERO et al., 2009), optou-se pela não utilização de padrão interno com a técnica de SPME.

\subsubsection{Parâmetros de Validação}

A partir dos testes de extração, as melhores condições para a análise do PCB por meio da técnica de SPME foram as seguintes: fibra PDMS/DVB $(65 \mu \mathrm{m})$, volume amostral de 2,0 $\mathrm{mL}$ adicionado de $0,5 \mathrm{~g}$ de $\mathrm{NaCl}$, temperatura ambiente de extração por 15 minutos sob constante agitação, e temperatura de $250^{\circ} \mathrm{C}$ de dessorção, por 16 minutos (Tabela 5-8). 
Os parâmetros de validação utilizados neste trabalho foram os seguintes: linearidade, limites de detecção e de quantificação, repetitividade e exatidão. Para a validação da extração de PCB de amostras de reatores por meio da técnica de SPME seguiu-se o procedimento estipulado por Ribani et al. (2004).

Tabela 5-8 As melhores condições definidas para a extração e análise do PCB por meio da técnica de SPME.

\begin{tabular}{|c|c|c|c|c|c|c|c|c|}
\hline $\begin{array}{c}\text { Tempo } \\
\text { agitação antes } \\
\text { da coleta }\end{array}$ & $\begin{array}{l}\text { Fibra de } \\
\text { SMPE }\end{array}$ & $\begin{array}{c}\text { Concentração } \\
\text { PCB } \\
\left(\mathrm{mg}^{-1} \mathrm{~L}^{-1}\right)\end{array}$ & $\begin{array}{l}\text { Volume de } \\
\text { amostra } \\
(\mathrm{mL}) \\
\end{array}$ & $\begin{array}{l}\mathrm{NaCl} \\
(\mathrm{g})\end{array}$ & $\begin{array}{l}\text { Temperatura } \\
\text { Extração }\left({ }^{\circ} \mathrm{C}\right)\end{array}$ & $\begin{array}{c}\text { Temperatura de } \\
\text { dessorção } \\
\left({ }^{\circ} \mathrm{C}\right)\end{array}$ & $\begin{array}{l}\text { Tempo de } \\
\text { extração } \\
(\text { min) } \\
\end{array}$ & $\begin{array}{l}\text { Tempo de } \\
\text { Dessorção } \\
\text { (min) }\end{array}$ \\
\hline 30 segundos & $\begin{array}{c}\text { PDMS/ } \\
\text { DVB } \\
(65 \mu \mathrm{m})\end{array}$ & $0,1-2,0$ & 2,0 & 0,5 & 22 & 250 & 15 & 16 minutos \\
\hline
\end{tabular}

\section{I) Linearidade e faixa de aplicação}

A linearidade está relacionada com a capacidade do método em proporcionar a obtenção de resultados diretamente proporcionais à concentração dos analitos em estudo, dentro de determinada faixa de aplicação (RIBANI et al., 2004). A linearidade do método foi avaliada por meio da relação matemática entre a resposta obtida e a concentração (ou massa), a partir dos sinais obtidos com concentrações conhecidas, expressa como curva analítica.

Aplicando-se o método matemático da regressão linear obteve-se o coeficiente linear e a inclinação, além do coeficiente de correlação, $\mathrm{R}^{2}$ (RIBANI et al., 2004). A curva analítica foi expressa por uma equação de reta a partir dos picos obtidos no cromatograma de concentrações conhecidas de PCB. A relação matemática entre o sinal e a concentração do analito foi calculada para cada congênere de PCB (Figura 5-10). Verificou-se para cada congênere de PCB, coeficiente de correlação maior do que 0,92 . Este coeficiente indica que a equação de regressão apresentou bom ajuste de acordo com os valores recomendado pelo INMETRO (2003), o qual recomenda valores acima de 0,90 para o coeficiente de correlação em validação de métodos cromatográficos de ensaios químicos.

Tanto, para LD, quanto para LQ é mais conveniente usar o método que considera os parâmetros da curva analítica, por ser mais confiável estatisticamente, uma vez que a relação sinal/ruído pode ser afetada pelo tamanho dos picos, podendo, portanto, ser subjetiva (RIBANI et al., 2004). Assim, os valores calculados de LD para os PCBs 10, 28, 52, 153, 138 e 180 foram 0,03 mg.L.-1, 0,01 mg.L - $^{-1}, 0,02$ mg.L $\mathrm{L}^{-1}, 0,02 \mathrm{mg} . \mathrm{L}^{-1}, 0,02 \mathrm{mg} . \mathrm{L}^{-1}$ e $0,02 \mathrm{mg} . \mathrm{L}^{-1}$, respectivamente (Figura 5-10). Os valores de LQ calculados por meio da equação de reta foram $0,10 \mathrm{mg} . \mathrm{L}^{-1}, 0,05 \mathrm{mg} . \mathrm{L}^{-1}, 0,07 \mathrm{mg} . \mathrm{L}^{-1}, 0,07 \mathrm{mg} . \mathrm{L}^{-1}, 0,07$ mg.L $\mathrm{L}^{-1}$ e 0,07 mg.L $\mathrm{L}^{-1}$ para os PCBs 10, 28, 52, 153, 138 e 180, respectivamente (Figura 5-10).

A sensibilidade, parâmetro calculado a partir da equação de reta da curva de calibração (ANGERER; SCHALLER, 1985; MILLER; MILLER, 1988; CHASIN et al., 1998) indica quão o método é sensível a mínimas variações de concentração do analito. De acordo com os autores Angerer; Schaller (1985), Miller e Miller (1988) e Chasin et al. (1998), a sensibilidade é definida como a inclinação da curva de calibração (coeficiente angular), e quanto maior esse valor, mais sensível é o método. Comparando-se o método de extração de cada congênere, é possível afirmar que a metodologia de SPME acoplada ao CG-ECD (cromatógrafo gasoso de captura de elétrons) foi mais sensível para o PCB 52, cujo coeficiente angular obtido foi de $2 \times 10^{6}$. 

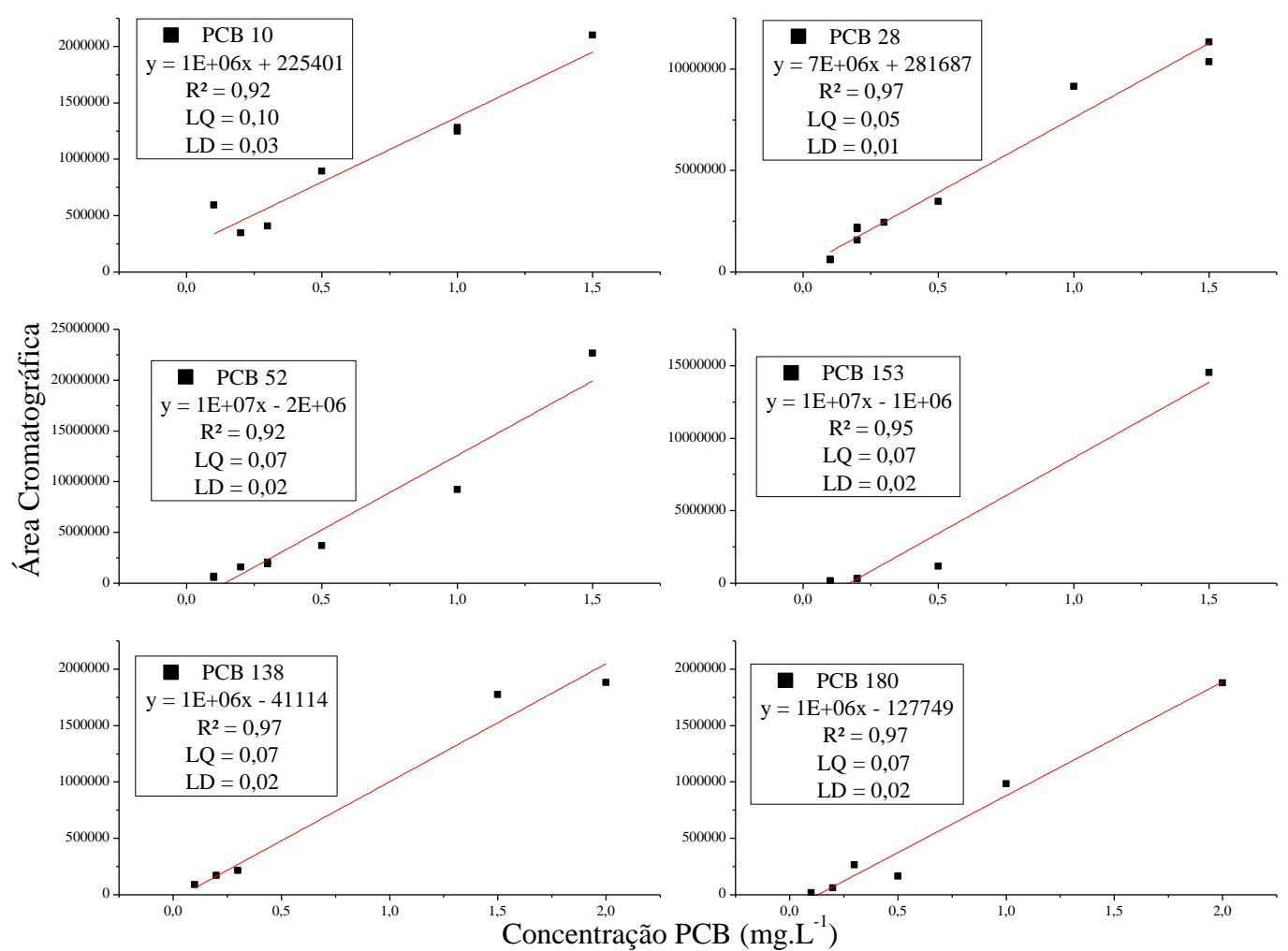

Figura 5-10 Determinação gráfica das curvas de linearidade da técnica de SPME para os congêneres PCB 10; PCB 28; PCB 52; PCB 153; PCB 138 e PCB 180. Estão apresentados os valores da equação da reta, $R^{2}$, LQ e LD de cada congênere. Símbolos representam dados, enquanto linha representa o ajuste da reta que representa a curva de calibração.

\section{II) Repetitividade}

A repetitividade representa a concordância entre os resultados de medições sucessivas de um mesmo método (RIBANI et al., 2004) e foi calculada pela Precisão Intra-dia e Precisão Inter-dia. Verificou-se para a Precisão Intra-dia variação de $0,1 \%$ a 27\%, expressa como o coeficiente de variação das áreas cromatográficas de cada congênere de PCB diluído em meio de cultura nas seis diferentes concentrações analisadas (Tabela 5-9).

Para os fins de validação do método, a variabilidade aceitável é dependente da concentração do analito (RIBANI et al., 2004), e neste trabalho foi encontrado um coeficiente de variação das áreas cromatográficas de quase $30 \%$, valor relativamente alto para o estudo e que confere uma problemática na utilização da técnica de SPME para a avaliação de PCB (RIBANI et al., 2004).

Os maiores valores do coeficiente de variação foram encontrados para $0,3 \mathrm{mg} \cdot \mathrm{L}^{-1}(27,4 \%)$ de PCB 10 e para 2,0 mg.. $\mathrm{L}^{-1}(21,1 \%)$ de PCB 28. Pode-se inferir que tais resultados devem estar relacionados com a resposta ao detector uma vez que existe uma relação direta entre a diminuição de sensibilidade do detector de captura de elétrons e o menor número de átomos de halogênio na molécula 
(TOBISZEWSKI; NAMIEŚNIK, 2011; ADORNO, 2013). Desta maneira os maiores valores de coeficiente de variação foram observados para PCB 10 e 28, com 2 e 3 átomos de cloro em sua molécula, respectivamente.

Tabela 5-9 Precisão Intra-dia do método de extração de PCB por SPME para cada analito diluído em meio sintético.

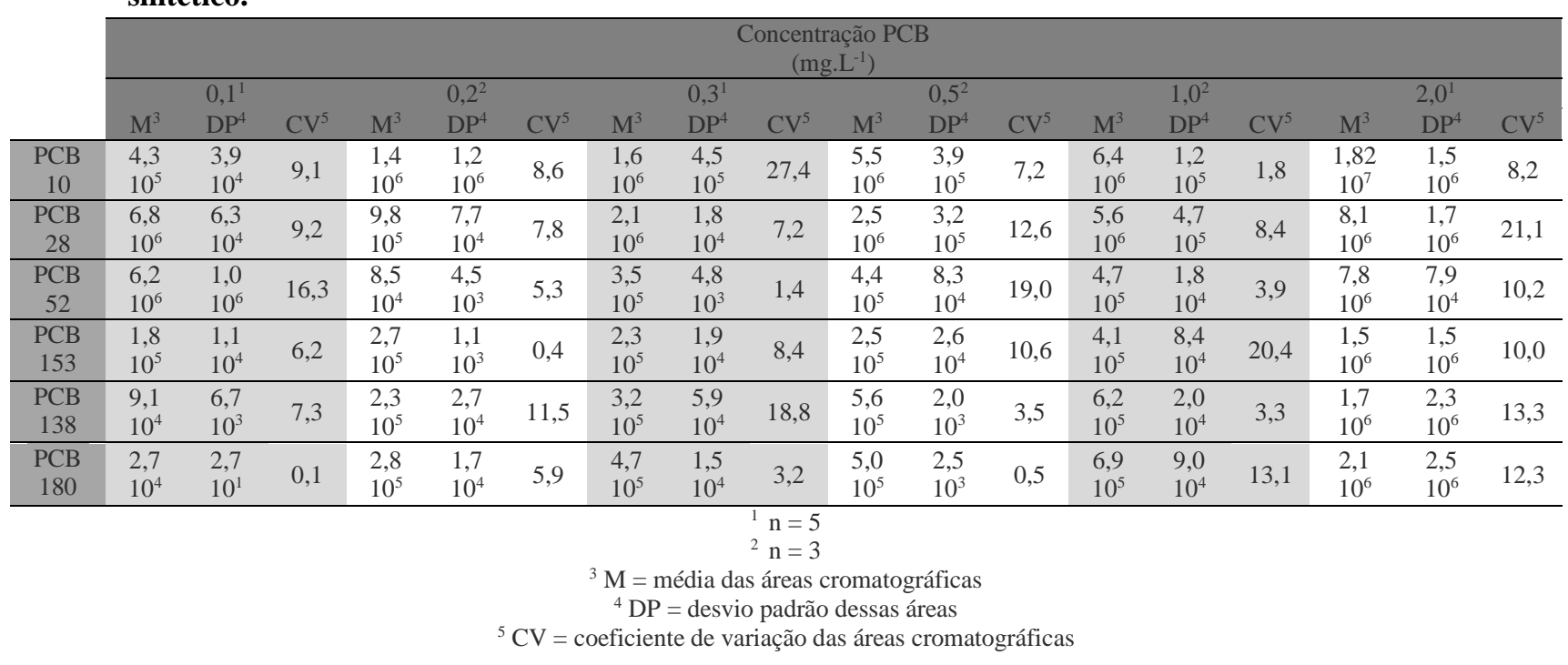

Por meio da precisão inter-dia (coeficiente de variação entre as análises realizadas em dias distintos) tem-se o efeito das variações dentro do laboratório e é descrita como a precisão mais representativa na validação de métodos cromatográficos (RIBANI et al., 2004). Verificou-se variação relativamente baixa entre os diferentes dias de análise, com valores de coeficiente de variação de 1,6\% até 17,7\% (Figura 5-11). O maior valor referente ao PCB 28 (17,7\%) pode estar relacionado com a resposta ao detector, encontrado também para a Precisão Intra-dia (TOBISZEWSKI; NAMIEŚNIK, 2011; ADORNO, 2013). 


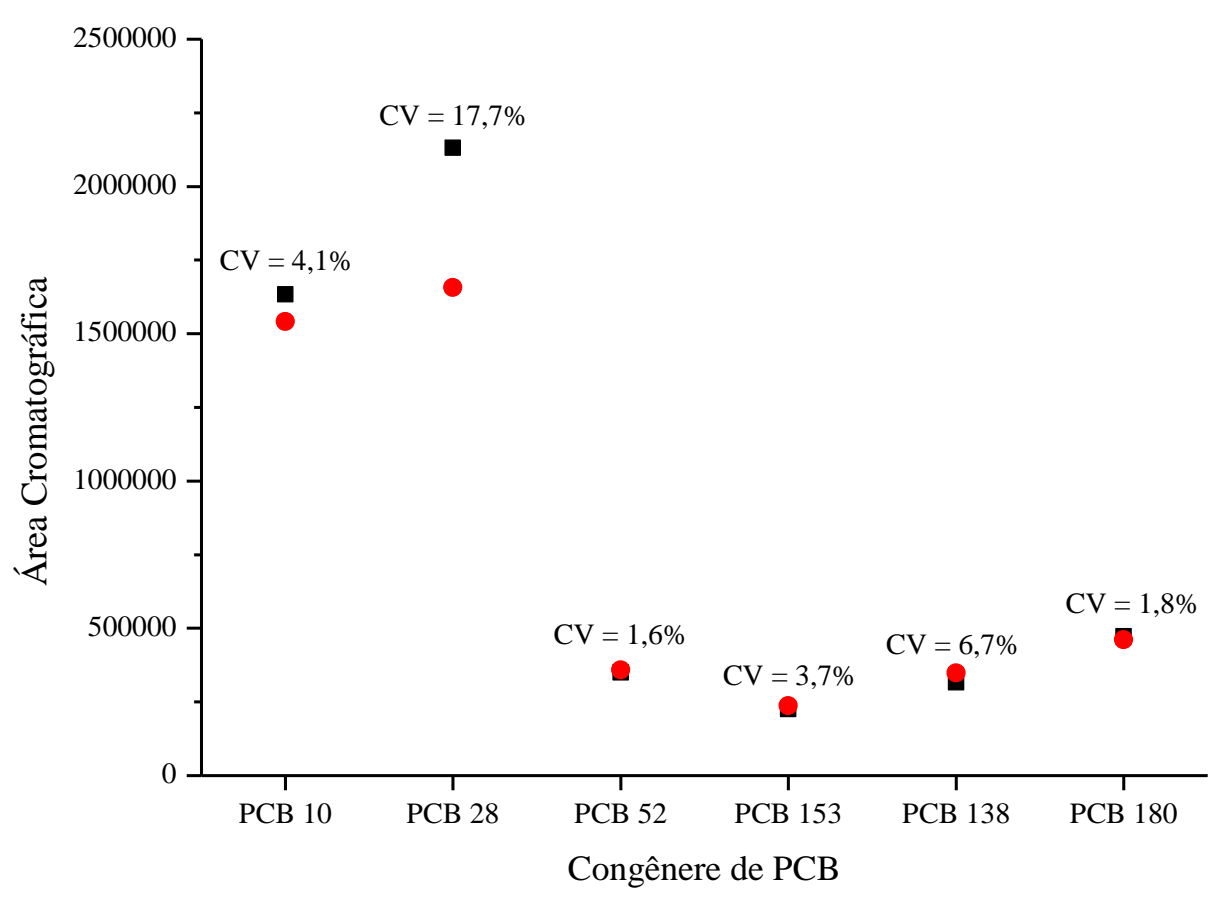

Figura 5-11 A precisão inter-dia através da área cromatográfica e coeficiente de variação entre as análises realizadas em dias distintos ( $\square$ dia 1 e $\square$ dia 2) para os seis congêneres de PCB avaliados pela técnica de SPME.

\section{III) Exatidão}

Os intervalos aceitáveis de recuperação para análise de resíduos geralmente estão entre 70 e $120 \%$ (RIBANI et al., 2004). Verificou-se recuperação relativa entre $80 \%$ e $112 \%$ para todas as concentrações analisadas $\left(0,1 \mathrm{mg} . \mathrm{L}^{-1}, 0,2 \mathrm{mg} . \mathrm{L}^{-1}\right.$ e $\left.0,3 \mathrm{mg} \cdot \mathrm{L}^{-1}\right)$ entre o PCB fortificado em água ultrapurificada e em meio sintético (Tabela 5-10). Por estes resultados pode-se inferir que a exatidão da aplicação do método de extração por meio do SPME de PCB foi obtida.

Tabela 5-10 Porcentagem de recuperação relativa entre água ultrapurificada e a amostra fortificada com PCB.

\begin{tabular}{cccc} 
Congênere de PCB & $0,1 \mathrm{mg} . \mathrm{L}^{-1}$ & $0,2 \mathrm{mg} . \mathrm{L}^{-1}$ & $0,3 \mathrm{mg} . \mathrm{L}^{-1}$ \\
\hline PCB 10 & $90,91 \%$ & $83,36 \%$ & $90,04 \%$ \\
\hline PCB 28 & $104,56 \%$ & $112,39 \%$ & $100,38 \%$ \\
\hline PCB 52 & $104,96 \%$ & $103,48 \%$ & $109,40 \%$ \\
\hline PCB 153 & $102,14 \%$ & $108,67 \%$ & $103,60 \%$ \\
\hline PCB 138 & $86,64 \%$ & $92,06 \%$ & $91,53 \%$ \\
\hline PCB 180 & $79,91 \%$ & $91,42 \%$ & $93,64 \%$ \\
\hline
\end{tabular}

\subsubsection{Determinação da concentração de PCB nos reatores em batelada}

Por meio de análises preliminares das amostras dos reatores em batelada verificou-se que a matriz, ou o lodo, interferiu diretamente na análise do PCB. Esta interferência da matriz também foi relatada por Llompart et al. (1998). Os autores verificaram que a concentração de PCB a partir de amostras 
ambientais eram menores daquelas analisadas em água ultrapurificada, confirmando o efeito de matriz. Com o intuito de minimizar o efeito da matriz nas amostras dos reatores foi utilizado o método de adição do padrão, ou Standard addiction, para quantificar o PCB proveniente de amostras dos reatores do Ensaio de Remoção de PCB (de Figura A. 1 a Figura A. 24, apêndice). O Standard addiction é utilizado para matrizes complexas, como o lodo, e a regressão da curva com a matriz resulta em uma curva de calibração mais próxima da real (OUYANG; PAWLISZYN, 2008).

\subsection{Ensaio Inibição Metanogênica}

No Ensaio de Inibição Metanogênica foi avaliado indiretamente quais concentrações de PCB eram mais tóxicas para a comunidade fermentativa-metanogênica. Para tanto, dois ensaios em batelada foram montados com lodo anaeróbio, co-substratos (etanol e formiato) e diferentes concentrações de PCB. O primeiro ensaio foi operado por 30 dias e o segundo ensaio, por 40 dias. Os resultados foram ajustados de acordo com a equação de Gompertz modificado (ZWIETERING et al., 1990).

A produção de metano dos reatores RC (reator controle) e R3,0 (3,0 mg. $\mathrm{L}^{-1}$ de $\mathrm{PCB}$ ) foi avaliada repetidamente tanto no primeiro ensaio de Inibição Metanogênica, quanto no segundo. A Produção Máxima Acumulada de Metano (PMM) foi representada graficamente ao longo do tempo de operação dos reatores para comparar as taxas relativas de metabolismo entre os reatores (Figura 5-12).

Nos reatores RC, tanto no primeiro Ensaio de Inibição Metanogênica, quanto no segundo, observou-se produção acumulada de metano (Figura 5-12 [a]) semelhantes entre si, com ajustes similares para a equação de Gompertz. Da mesma forma, verificou-se para os reatores R3,0, PMM e ajuste da equação de Gompertz semelhantes em ambos os ensaios (primeiro e segundo ensaio de Inibição Metanogênica) (Figura 5-12 [b]). No primeiro ensaio obteve-se $\mathrm{R}^{2}$ de ajuste da equação de Gompertz dos reatores RC e R3,0 de 0,93 e 0,94 , respectivamente. No segundo ensaio obteve-se o $\mathrm{R}^{2}$ dos reatores RC e R3,0 de 0,94 e 0,96, respectivamente. Assim, neste trabalho foi escolhido os dados do segundo ensaio tanto para os reatores RC, quanto para R3,0 para o cálculo da Inibição Metanogênica, pois melhor se ajustou a equação de Gompertz modificada. 


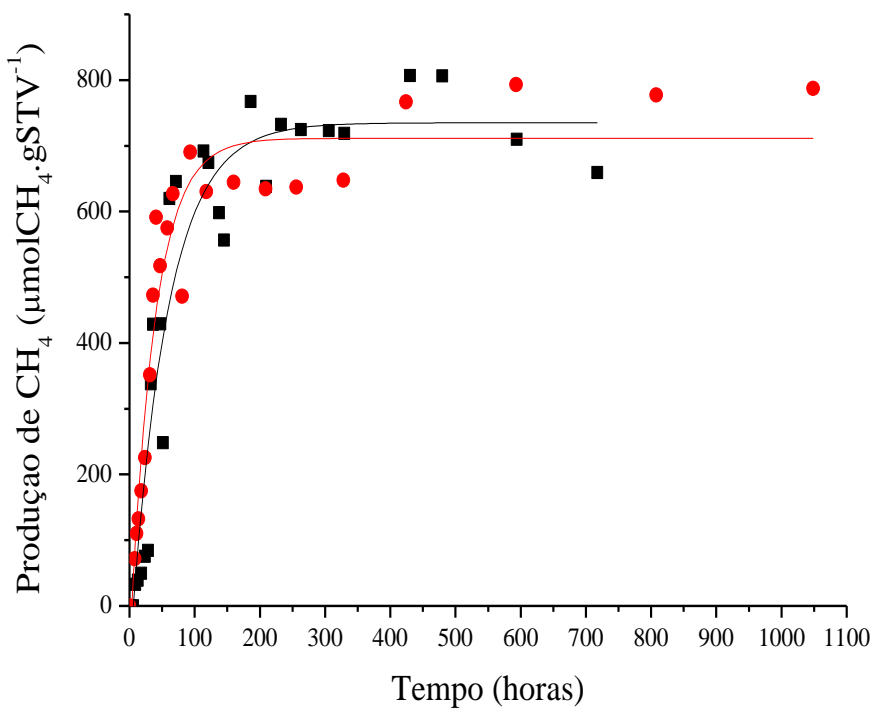

(a)

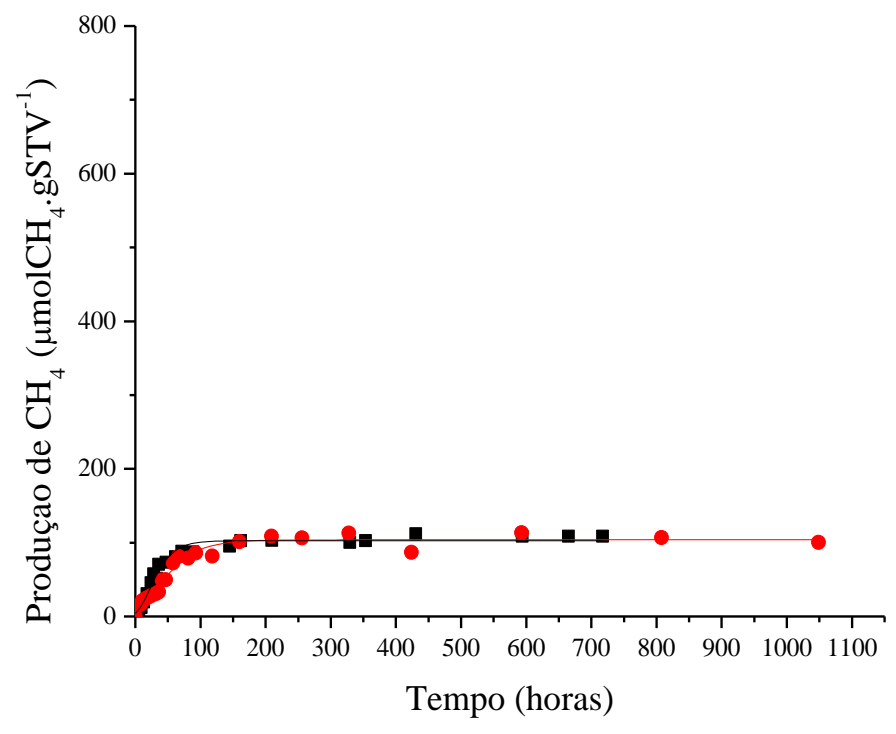

(b)

Figura 5-12 Produção acumulada de metano para (a) RC e (b) R3,0 em ambos os ensaios (primeiro - $\square$ - e segundo ensaio -๑-). Linha representa o ajuste através da equação de Gompertz modificado e símbolos representam os dados. 
A produção de metano ao longo do tempo, a produção máxima acumulada de metano (PMM) e a velocidade de produção de metano (VPM) estão apresentados na Figura 5-13. Obteve-se para todas as amostras $R^{2}$ de ajuste da equação de Gompertz valor maior que 0,92 . Por meio do teste t-Student foi verificado diferença estatística $(\mathrm{P}<0.05)$ nos valores de $\mathrm{PMM}$ para as diferentes concentrações de $\mathrm{PCB}$. Para as condições do reator branco (RB) não se verificou produção de metano e não foram apresentados esses resultados.

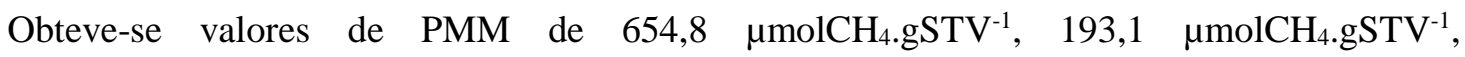
111,6 $\mu \mathrm{molCH}_{4} \cdot \mathrm{gSTV}^{-1}, 104,6 \mu \mathrm{molCH}_{4} \cdot \mathrm{gSTV}^{-1}, 96,7 \mu \mathrm{molCH}_{4} \cdot \mathrm{gSTV}^{-1}$ e 79,5 $\mu \mathrm{molCH}_{4} \cdot \mathrm{gSTV}^{-1}$ para os reatores RC, R0,5, R1,5, R3,0, R4,5 e R6,0, respectivamente (Figura 5-13). A partir desses resultados foi possível observar diminuição da PMM com o aumento da concentração de PCB nos reatores anaeróbios. Desse modo, pode-se inferir sobre o efeito inibitório do PCB na produção de metano.

Ademais, verificou-se maior VPM para as condições do RC, seguido dos reatores R0,5, R1,5, $\mathrm{R} 3,0$, R4,5 e R6,0, cujos valores foram de $15,5 \mu \mathrm{molCH}_{4} \cdot \mathrm{gSTV}^{-1} \cdot \mathrm{h}^{-1}, 2,6 \mu \mathrm{molCH}_{4} \cdot \mathrm{gSTV}^{-1} \cdot \mathrm{h}^{-1}, 0,7$ $\mu \mathrm{molCH}_{4} \cdot \mathrm{gSTV}^{-1} \cdot \mathrm{h}^{-1}, 1,1 \mu \mathrm{molCH}_{4} \cdot \mathrm{gSTV}^{-1} \cdot \mathrm{h}^{-1}, 1,0 \mu \mathrm{molCH}_{4} \cdot \mathrm{gSTV}^{-1} \cdot \mathrm{h}^{-1}, 0,7 \mu \mathrm{molCH}_{4} \cdot \mathrm{gSTV}^{-1} \cdot \mathrm{h}^{-1}$, respectivamente (Figura 5-13). A partir destes resultados foi possível verificar que a velocidade de produção de metano foi diretamente influenciada pela adição de PCB no sistema, e no reator sem adição de PCB a velocidade foi mais alta $\left(15,5 \mu \mathrm{molCH}_{4} \cdot \mathrm{gSTV}^{-1} \cdot \mathrm{h}^{-1}\right)$, quando comparada com os reatores em que o PCB estava presente (entre 2,6 $\mu \mathrm{molCH}_{4} \cdot \mathrm{gSTV}^{-1} \cdot \mathrm{h}^{-1}$ e $0,7 \mu \mathrm{molCH}_{4} \cdot \mathrm{gSTV}^{-1} \cdot \mathrm{h}^{-1}$ ). 


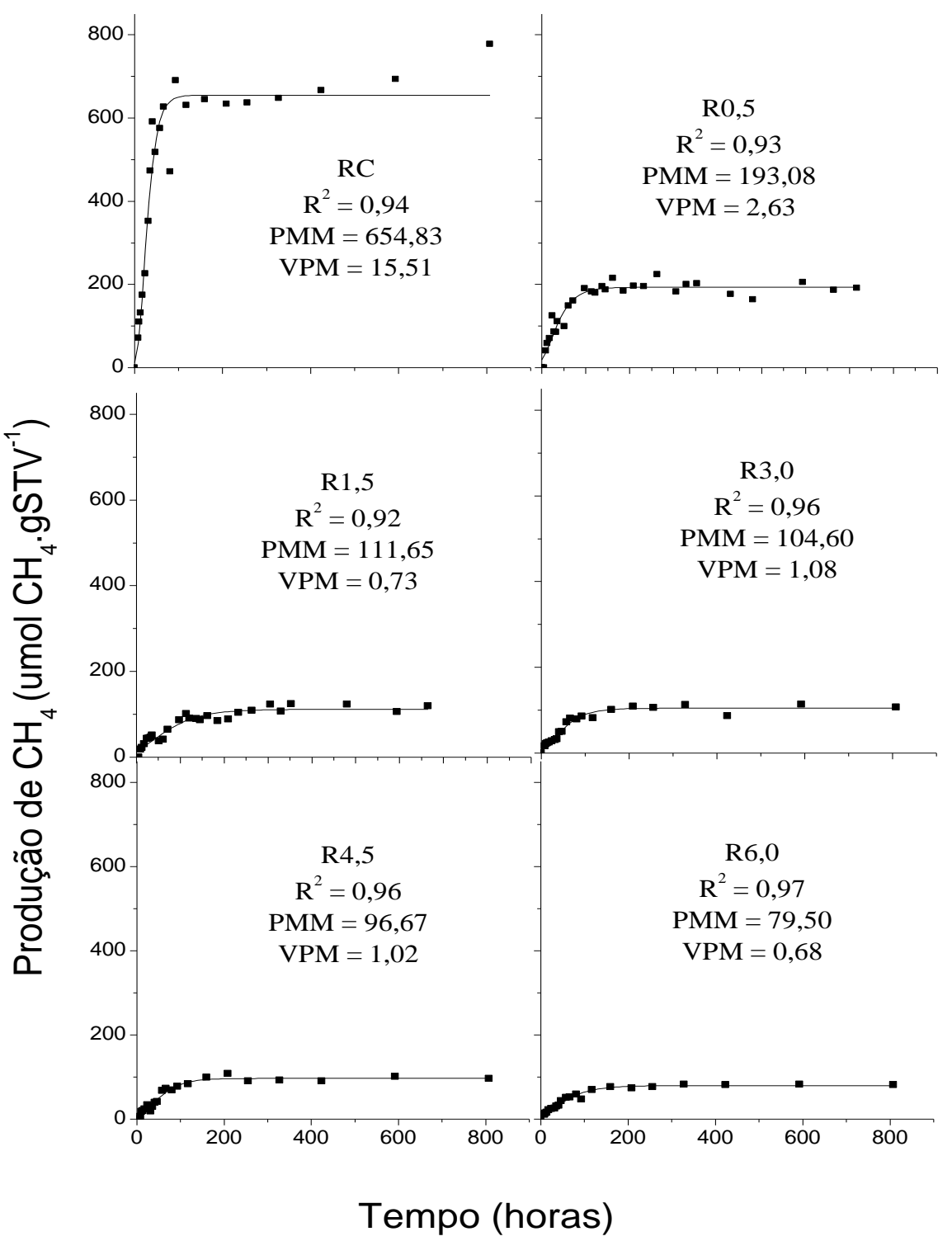

Figura 5-13 Produção de metano nos reatores metanogênicos sob diferentes concentrações de PCB. RC: reator controle (sem PCB); R0,5: 0,5 mg.L $\mathrm{L}^{-1}$ de PCB; R1,5: 1,5 mg.L $\mathrm{L}^{-1}$ de PCB; R3,0: 3,0 mg.L $\mathrm{L}^{-1}$ de PCB; R4,5: 4,5 mg. $\mathrm{L}^{-1}$ de PCB e R6,0: 6,0 mg.L $\mathrm{L}^{-1}$ de PCB. $\mathrm{R}^{2}$ é o coeficiente de correlação, PMM a Produção Máxima Especifica de Metano $\left(\mu \mathrm{molCH}_{4} . \mathrm{gSTV}^{-1}\right)$ e VPM a velocidade de produção de metano $\left(\mu \mathrm{molCH} 4 . \mathrm{gSTV}^{-1} \cdot \mathrm{h}^{-1}\right)$. Símbolos representam valores medidos, enquanto linha representa o ajuste a equação modificada de Gompertz.

Gomes et al. (2014) avaliaram a produção de metano em reatores em batelada, sob condições similares de operação desse trabalho, com etanol $\left(460 \mathrm{mg} . \mathrm{L}^{-1}\right)$ e formiato de sódio $\left(680 \mathrm{mg} . \mathrm{L}^{-1}\right)$ como co-substratos e congêneres de PCB (PCB 10, 28, 52, 153, 138 e 180), além de inóculo proveniente de reator UASB tratando efluente de avicultura. Os autores observaram para os reatores controle, com co-substratos e lodo anaeróbio suspenso, produção máxima de metano de $900 \mu \mathrm{molCH}_{4} \cdot \mathrm{gSTV}^{-1}$. Nos 
reatores com PCB $\left(0,7\right.$ mg. $\left.\mathrm{L}^{-1}\right)$, co-substratos e lodo anaeróbio suspenso, obtiveram $400 \mu \mathrm{molCH}_{4} . \mathrm{gSTV}^{-1}$.

Comparando-se os resultados obtidos para os reatores sem PCB e com baixa concentração de PCB do presente trabalho $\left(654,8 \mu\right.$ molCH$_{4} \cdot \mathrm{gSTV}^{-1}$ e $193,1 \mu \mathrm{molCH}_{4} \cdot \mathrm{gSTV}^{-1}$, para RC e R0,5 respectivamente) e aqueles obtidos por Gomes et al. (2014) $\left(900 \mu \mathrm{molCH}_{4} \cdot \mathrm{gSTV}^{-1}\right.$ e $400 \mu \mathrm{molCH}_{4} . \mathrm{gSTV}^{-1}$, para reator controle e reator com $0,7 \mathrm{mg} . \mathrm{L}^{-1}$, respectivamente) foi possível verificar menor produção máxima de metano nos reatores do presente estudo (Tabela 5-11).

Destaca-se que as condições de operação dos reatores anaeróbios realizadas por Gomes et al. (2014) e do presente estudo foram similares, como a presença de material suporte, o meio sintético utilizado e inclusive a mesma origem de biomassa utilizada como inóculo dos reatores. Todavia, no presente estudo obteve-se menor produção de metano em relação àquela de Gomes et al. (2014). Provavelmente, esses resultados podem estar relacionados com diferentes tempos de armazenamento do inóculo proveniente do reator UASB em geladeira, consequentemente, com alteração do metabolismo e diversidade das populações de microrganismos. No presente trabalho foi utilizado inóculo mais antigo e foi obtido menor produção de metano do que Gomes et al. (2014). A determinação do potencial metanogênico é um método biológico sujeito a grandes variações devido à utilização de inóculo nãopadronizado e heterogêneo e as característica do lodo pode estar diretamente ligada à diminuição do potencial metanogênico da amostra (HANSEN et al., 2004).

Tabela 5-11 Comparação entre a produção máxima de metano nos reatores em batelada sem PCB e com concentrações baixas de PCB $\left(0,5 \mathrm{mg} . \mathrm{L}^{-1}\right.$ e $\left.0,7 \mathrm{mg} . \mathrm{L}^{-1}\right)$ no presente estudo e literatura.

\begin{tabular}{cc|c} 
& Presente Estudo & Gomes et al. (2014) \\
\cline { 2 - 3 } Reator Controle & $654,8 \mu \mathrm{molCH}_{4} \cdot \mathrm{gSTV}^{-1}$ & $900 \mu \mathrm{molCH}_{4} \cdot \mathrm{gSTV}^{-1}$ \\
\hline Reator com $0,5 \mathrm{mg} \cdot \mathrm{L}^{-1} \mathrm{de} \mathrm{PCB}$ & $193,1 \mu \mathrm{molCH}_{4} \cdot \mathrm{gSTV}^{-1}$ & - \\
\hline Reator com $0,7 \mathrm{mg} \cdot \mathrm{L}^{-1} \mathrm{de}$ PCB & - & $400 \mu \mathrm{molCH}_{4} \cdot \mathrm{gSTV}^{-1}$ \\
\hline
\end{tabular}

A produção máxima de metano (PMM) do reator controle ( $\mathrm{RC}$ ) foi utilizado na comparação da taxa de inibição em relação aos reatores R0,5, R1,5, R3,0, R4,5 e R6,0, com 0,5 mg.L $\mathrm{L}^{-1}$, 1,5 mg.L $\mathrm{L}^{-1}, 3,0$ mg.L $\mathrm{L}^{-1}, 4,5 \mathrm{mg} . \mathrm{L}^{-1}$ e $6,0 \mathrm{mg} . \mathrm{L}^{-1}$ de PCB, respectivamente (Tabela 5-12).

Neste estudo verificou-se correlação direta entre a concentração de PCB adicionada no reator e a inibição metanogênica (Tabela 5-12). Nos reatores em batelada com 0,5 mg.L $\mathrm{L}^{-1}, 1,5 \mathrm{mg} . \mathrm{L}^{-1}, 3,0 \mathrm{mg} . \mathrm{L}^{-}$ 1, 4,5 mg.L. - $^{-1}$ e 6,0 mg.L.-1 de PCB obteve-se taxas de inibição de 70,5\%, 83,0\%, 84,0\%, 85,2\% e 87,5\%, respectivamente.

Kaya; Imamoglu; Sanin (2013a) determinaram a produção de metano em reatores anaeróbios com inóculo misto (lodo anaeróbio e lodos ativados) contendo PCB 118, sem co-substrato. Estes autores avaliaram a porcentagem da produção de metano com PCB em comparação com o grupo controle, e a porcentagem de inibição calculada foi 9,3\%, 15,6\% e 17,8\% para 10, 20 e 30 mg.L ${ }^{-1}$ de PCB 118 em 65 dias.

Comparando-se os resultados de inibição metanogênica obtidos no presente trabalho (inibição de 70,5\%, 83,0\%, 84,0\%, 85,2\% e 87,5\% para 0,5 mg.L ${ }^{-1}, 1,5 \mathrm{mg} . \mathrm{L}^{-1}, 3,0 \mathrm{mg} . \mathrm{L}^{-1}, 4,5 \mathrm{mg} . \mathrm{L}^{-1}$ e $6,0 \mathrm{mg} . \mathrm{L}^{-}$ ${ }^{1}$ de PCB, respectivamente) e aqueles obtidos por Kaya; Imamoglu; Sanin (2013a) (inibição de 9,3\%, $15,6 \%$ e 17,8\% para 10, 20 e $30 \mathrm{mg} . \mathrm{L}^{-1}$ de PCB 118) verificou-se maior inibição metanogênica sob as condições nutricionais do presente estudo. 
Sierra-Alvarez; Lettinga (1991) confirmaram que existe relação entre a estrutura molecular do composto aromático e seu efeito inibitório sob a comunidade metanogênica do lodo granular de reator UASB. Assim, a distinta taxa de inibição metanogênica obtida no presente estudo e aquela obtida por Kaya; Imamoglu; Sanin (2013a), provavelmente, esteja relacionada com as características químicas do congênere de PCB, bem como, com a fonte de inóculo utilizada nos respectivos trabalhos, de grande importância no cálculo da taxa de inibição.

Verificou-se comportamento similar ao da produção de metano para a remoção de matéria orgânica nos reatores em batelada, sendo observada diminuição efetiva na eficiência de remoção para maiores concentrações de PCB (Tabela 5-12). Verificou-se eficiência de remoção de DQO para os reatores RC, R0,5, R1,5, R3,0, R4,5 e R6,0 de 60\%, 52\%, 46\%, 39\%, 31\% e 24\%, respectivamente (para 940,17 mg.L. $\mathrm{L}^{-1}$, 1.605,25 mg.L. ${ }^{-1}$, 2.247,50 mg.L $\mathrm{L}^{-1}$, 3.603,25 mg.L $\mathrm{L}^{-1}, 5.003,00 \mathrm{mg} . \mathrm{L}^{-1}$ e 7.116,00 mg.L ${ }^{-1}$ de DQO inicial, respectivamente). Resultados similares foram obtidos por Kaya; Imamoglu; Sanin (2013a). Os autores verificaram menor eficiência de remoção de DQO (25.000 mg.L. $\mathrm{L}^{-1}$ de DQO inicial) nos reatores em batelada metanogênicos para maiores concentrações de PCB-118 (eficiência de remoção

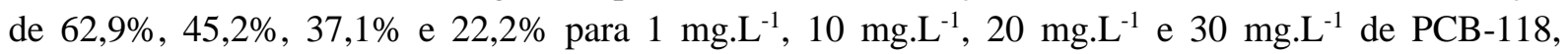
respectivamente). Assim, pode-se inferir que o PCB teve efeito inibitório não apenas no metabolismo metanogênico, mas também na remoção de matéria orgânica no sistema.

Tabela 5-12 Ácidos orgânicos voláteis, inibição, produção máxima especifica de metano, DQO inicial e final e eficiência de remoção de DQO em cada reator no Ensaio de Inibição Metanogênica.

\begin{tabular}{|c|c|c|c|c|c|}
\hline Reator & $\begin{array}{l}\text { Inibição } \\
(\%)\end{array}$ & $\begin{array}{c}\mathrm{PMM} \\
\left(\mu \mathrm{molCH}_{4}, \mathrm{gSTV}^{-1}\right)\end{array}$ & $\begin{array}{l}\text { DQO inicial } \\
\left(\mathrm{mg} \cdot \mathrm{L}^{-1}\right)\end{array}$ & DQO final (mg. $\left.\mathrm{L}^{-1}\right)$ & $\begin{array}{c}\text { Eficiência de remoção de DQO } \\
(\%)\end{array}$ \\
\hline $\mathrm{RC}$ & - & 654,83 & $\begin{array}{l}940,17 \\
( \pm 8,71) \\
\end{array}$ & $\begin{array}{c}376,07 \\
( \pm 30,60) \\
\end{array}$ & 60 \\
\hline $\mathrm{R} 0,5$ & 70,5 & 193,08 & $\begin{array}{l}1.605,25 \\
( \pm 25,70)\end{array}$ & $\begin{array}{c}770,52 \\
( \pm 38,41)\end{array}$ & 52 \\
\hline $\mathrm{R} 1,5$ & 83,0 & 111,65 & $\begin{array}{l}2.247,50 \\
( \pm 45,70)\end{array}$ & $\begin{array}{l}1.213,65 \\
( \pm 142,70)\end{array}$ & 46 \\
\hline $\mathrm{R} 3,0$ & 84,0 & 104,60 & $\begin{array}{l}3.603,25 \\
( \pm 252,75)\end{array}$ & $\begin{array}{l}2.197,98 \\
( \pm 351,00)\end{array}$ & 39 \\
\hline $\mathrm{R} 4,5$ & 85,2 & 96,67 & $\begin{array}{l}5.003,00 \\
( \pm 500,00)\end{array}$ & $\begin{array}{l}3.452,07 \\
( \pm 457,71)\end{array}$ & 31 \\
\hline $\mathrm{R} 6,0$ & 87,9 & 79,50 & $\begin{array}{l}7.116,00 \\
( \pm 489,00)\end{array}$ & $\begin{array}{l}5.408,16 \\
( \pm 245,50)\end{array}$ & 24 \\
\hline
\end{tabular}

Neste trabalho constatou-se diferentes concentrações e distribuição de ácidos orgânicos voláteis nos reatores em batelada que foi dependente da concentração de PCB (Tabela 5-13). O acúmulo de ácidos orgânicos voláteis foi crescente com o aumento da concentração de PCB nos reatores R0,5, R1,5 e R3,0, cujas concentrações totais de ácidos orgânicos voláteis foram de 1.078,29 mg.L $\mathrm{L}^{-1}$, 1.766,25 mg.L${ }^{1}$ e 2.003,43 mg.L $\mathrm{L}^{-1}$, respectivamente. Para 4,5 mg.L ${ }^{-1}$ e 6,0 mg.L. $\mathrm{L}^{-1}$ de PCB não verificou-se acúmulo de ácidos orgânicos voláteis, sendo observados 198,01 mg.L $\mathrm{L}^{-1}$ e 72,96 mg.L $\mathrm{L}^{-1}$, respectivamente. O acúmulo de ácidos orgânicos voláteis em reatores anaeróbios em batelada foi evidenciado por García-Morales et al. (2001). Em seu trabalho, esses autores vincularam a alta concentração de ácidos orgânicos voláteis na operação dos reatores ao aumento da concentração de alquibenzeno-sulfonado e a consequente inibição metanogênica no sistema. A inibição metanogênica ocasionou a diminuição do consumo de metabólitos, como os ácidos orgânicos, e resultou no acúmulos destes nos reatores. 
De acordo com Boone et al. (1993) e Krocker et al. (1979) a presença de substâncias inibitórias na alimentação pode influenciar a metanogênese, causando a conversão incompleta dos ácidos orgânicos voláteis a metano. De tal modo, nos reatores com elevada concentração de ácidos orgânicos voláteis, R0,5, R1,5 e R3,0, foi possível inferir que a metanogênese tenha sido inibida, atingindo PMM de 193,08 $\mu \mathrm{molCH}_{4} . \mathrm{gSTV}^{-1}, 111,65 \mu \mathrm{molCH}_{4} \cdot \mathrm{gSTV}^{-1}$ e 111,65 $\mu \mathrm{molCH}_{4} \cdot \mathrm{gSTV}^{-1}$, respectivamente, e a digestão anaeróbia foi incompleta, apenas com a fase acidogênica.

A partir da análise de ácidos orgânicos voláteis dos reatores foi possível verificar que (Figura 5-14 e Tabela 5-13) o ácido acético foi o principal ácido orgânico volátil observado nos reatores R0,5, R1,5 e R3,0, com 794,0 mg.L.-1, 793,6 mg.L $\mathrm{L}^{-1}$ e 1.014,5 mg.L $\mathrm{L}^{-1}$, respectivamente. Pode-se inferir a partir desses resultados que a rota metanogênica acetoclástica foi inibida com o aumento da concentração de PCB.

Ademais, como o formiato de sódio adicionado no início da operação $\left(396,0 \mathrm{mg} \cdot \mathrm{L}^{-1}\right)$ foi consumido (47,2 mg.L. ${ }^{-1}, 29,7$ mg.L ${ }^{-1}$ e 50,0 mg.L ${ }^{-1}$ para os reatores R0,5, R1,5 e R3,0, respectivamente), pode-se inferir que o metano produzido nestes reatores foi principalmente por meio do metabolismo metanogênico hidrogenotrófico.

$\mathrm{Xu}$ et al. (2010) avaliaram como os inibidores clássicos da metanogênese (2-bromoetanosulfonado e clorofórmio) alteraram a comunidade microbiana anaeróbia. Os autores constataram que a comunidade acetoclástica foi mais sensível à presença de inibidores do que as metanogênicas hidrogenotróficas. Ademais, Gomes et al. (2014) evidenciaram inibição metanogênica acetoclástica em reatores em batelada inoculados com lodo anaeróbio de reator UASB tratando efluente de avicultura com 0,7 mg. $\mathrm{L}^{-1}$ de PCB. Portanto, é possível afirmar que as arqueias acetoclásticas são mais sensíveis a presença do PCB do que as populações metanogênicas hidrogenotróficas.

Outros produtos principais nos reatores R0,5, R1,5 e R3,0 foram o ácido butírico (336,0 mg.L $\mathrm{L}^{-1}$ e $630,9 \mathrm{mg} . \mathrm{L}^{-1}$ para os reatores R1,5 e R3,0, respectivamente) e o ácido propiônico (83,0 mg.L $\mathrm{L}^{-1}$ para o reator R0,5). Xu et al. (2010) constataram que as formas não ionizadas do ácido acético (entre 22.000 $\mu$ mol. $L^{-1}$ e $27.000 \mu$ mol. $L^{-1}$ ), do ácido butírico (entre $600 \mu$ mol.L $L^{-1}$ e $700 \mu$ mol.L ${ }^{-1}$ ) e do ácido propiônico (entre $9.000 \mu$ mol.L $\mathrm{L}^{-1}$ e $11.000 \mu$ mol.L $\mathrm{L}^{-1}$ ) eram os principais metabólitos acumulados nos sistemas com altas taxa de inibição metanogênica (95\% de inibição).

Casserly; Erijman (2003) evidenciaram que o acúmulo de ácidos orgânicos ocorre quando há baixa atividade metanogênica associada a alta atividade fermentativa. Portanto, a partir do acumulo dos ácidos acético, butírico e propiônico, neste trabalho, pode-se salientar que houve inibição metanogênica conjuntamente com a alta atividade acidogênica nos reatores R0,5, R1,5 e R3,0.

As bactérias acidogênicas são menos sensíveis aos compostos tóxicos em comparação com as arqueias metanogênicas (KIM; YOUNG; TABAK, 1994; GARCÍA-MORALES et al., 2001; WARREN et al., 2003; OCHOA-HERRERA et al., 2009). Com isso pode-se sugerir que no presente trabalho as bactérias acidogênicas foram menos sensíveis a adição do PCB do que as arqueias metanogênicas.

Nos reatores R4,5 e R6,0 foi evidenciado menor produção de metano, 96,7 $\mu \mathrm{molCH}_{4} \cdot \mathrm{gSTV}^{-1} \mathrm{e}$ $79,5 \mu \mathrm{molCH}_{4} . \mathrm{gSTV}^{-1}$, respectivamente, e menor acúmulo de ácidos orgânicos voláteis, 96,4 mg.L $\mathrm{L}^{-1} \mathrm{e}$ 46,8 mg. $\mathrm{L}^{-1}$, respectivamente. Por meio destes resultados destaca-se que para concentrações acima de 4,5 mg. $\mathrm{L}^{-1}$ de PCB, tanto as populações metanogênicas, quanto as acidogênica foram inibidas. 
Tabela 5-13 Porcentagem e concentração de cada ácido orgânico volátil nos reatores $\mathrm{RC}$ (reator controle), R0,5 (reator com 0,5 mg. $\mathrm{L}^{-1}$ de PCB), R1,5 (reator com 1,5 mg.L $\mathrm{L}^{-1}$ de PCB), R3,0 (reator com 3,0 mg.L $\mathrm{L}^{-1}$ de PCB), R4,5 (reator com 4,5 mg.L $\mathrm{L}^{-1}$ de PCB) e R6,0 (reator com 6,0 mg.L $\mathrm{L}^{-1}$ de PCB).

\begin{tabular}{|c|c|c|c|c|c|c|c|c|c|}
\hline Amostra & Unidade & $\begin{array}{c}\text { Ácido } \\
\text { fórmico }\end{array}$ & $\begin{array}{l}\text { Ácido } \\
\text { acético }\end{array}$ & $\begin{array}{c}\text { Ácido } \\
\text { propiônico }\end{array}$ & $\begin{array}{c}\text { Ácido } \\
\text { isobutírico }\end{array}$ & $\begin{array}{l}\text { Ácido } \\
\text { butírico }\end{array}$ & $\begin{array}{c}\text { Ácido } \\
\text { isovalérico }\end{array}$ & Metanol & Total \\
\hline $\mathrm{RC}$ & mg. $\mathrm{L}^{-1}$ & 0,00 & 8,83 & 0,00 & 0,00 & 0,00 & 0,00 & 61,86 & 70,69 \\
\hline $\mathrm{R} 0,5$ & mg. $\mathrm{L}^{-1}$ & 47,15 & 794,41 & 83,21 & 61,36 & 9,02 & 83,14 & 0,00 & $1.078,29$ \\
\hline $\mathrm{R} 1,5$ & $\mathrm{mg} \cdot \mathrm{L}^{-1}$ & 29,73 & 793,64 & 25,48 & 21,31 & 336,07 & 26,29 & 533,73 & $1.766,25$ \\
\hline $\mathrm{R} 3,0$ & $\mathrm{mg} \cdot \mathrm{L}^{-1}$ & 50,06 & $1.014,52$ & 116,17 & 70,20 & 630,88 & 121,60 & 0,00 & $2.003,43$ \\
\hline $\mathrm{R} 4,5$ & $\mathrm{mg} \cdot \mathrm{L}^{-1}$ & 0,02 & 55,87 & 23,27 & 3,84 & 0,00 & 9,24 & 105,77 & 198,01 \\
\hline $\mathrm{R} 6,0$ & $\mathrm{mg} \cdot \mathrm{L}^{-1}$ & 2,65 & 35,71 & 3,42 & 0,75 & 0,00 & 4,28 & 26,14 & 72,96 \\
\hline $\mathrm{RC}$ & $\%$ & 97,76 & 0,87 & 1,01 & 0,37 & 0,00 & 0,00 & 0,00 & 100 \\
\hline $\mathrm{R} 0,5$ & $\%$ & 0,00 & 12,49 & 0,00 & 0,00 & 0,00 & 0,00 & 87,51 & 100 \\
\hline $\mathrm{R} 1,5$ & $\%$ & 4,37 & 73,67 & 7,72 & 5,69 & 0,84 & 7,71 & 0,00 & 100 \\
\hline $\mathrm{R} 3,0$ & $\%$ & 1,68 & 44,93 & 1,44 & 1,21 & 19,03 & 1,49 & 30,22 & 100 \\
\hline $\mathrm{R} 4,5$ & $\%$ & 2,50 & 50,64 & 5,80 & 3,50 & 31,49 & 6,07 & 0,00 & 100 \\
\hline $\mathrm{R} 6,0$ & $\%$ & 0,01 & 28,22 & 11,75 & 1,94 & 0,00 & 4,67 & 53,42 & 100 \\
\hline
\end{tabular}

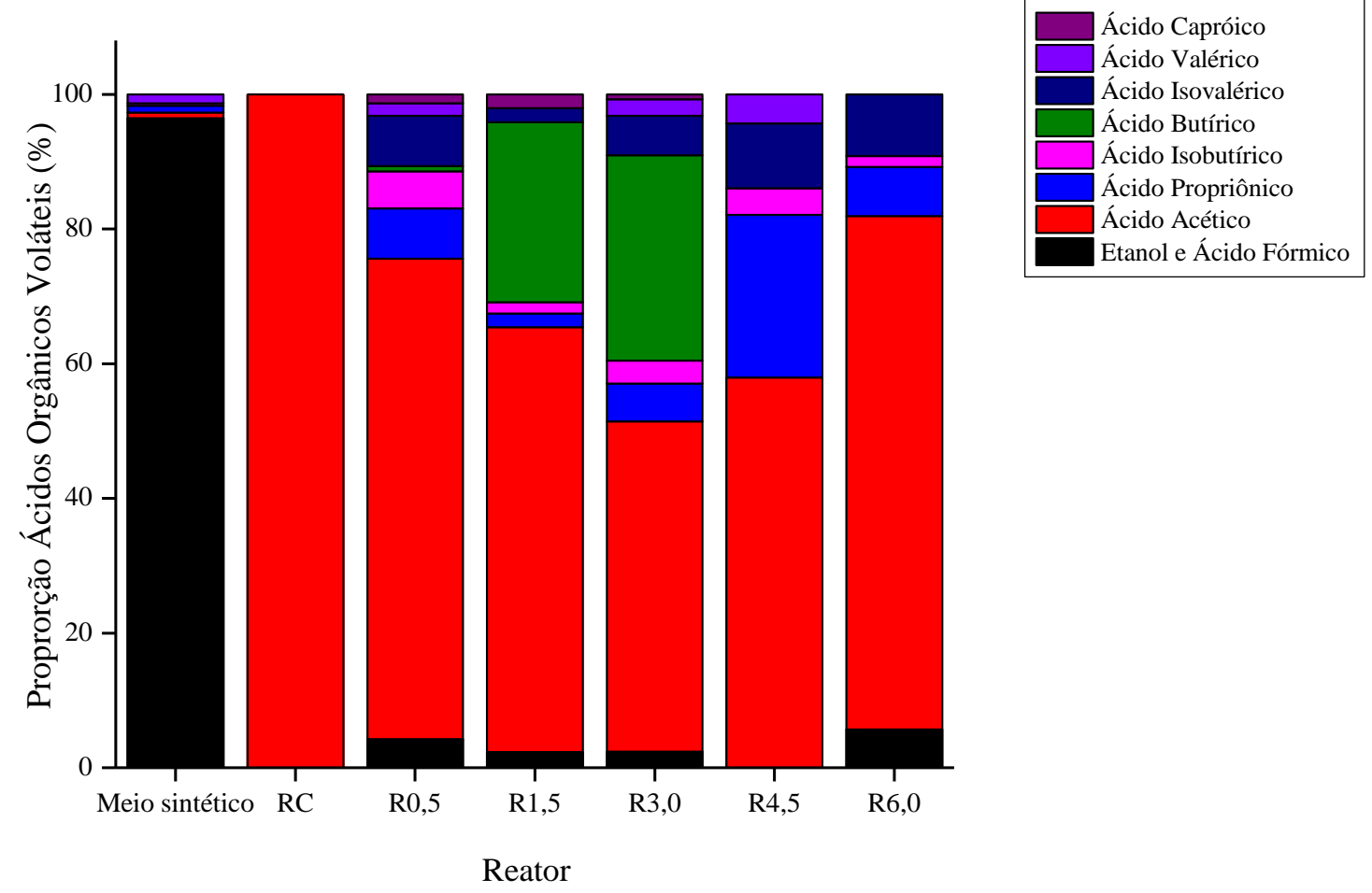

Figura 5-14 Proporção de cada ácido orgânico volátil no meio sintético (meio sintético mais fontes de carbono) e nos reatores $\mathrm{RC}$ (reator controle), R0,5 (reator com 0,5 mg. $\mathrm{L}^{-1}$ de PCB), R1,5 (reator com 1,5 
mg.L ${ }^{-1}$ de PCB), R3,0 (reator com 3,0 mg.L $\mathrm{L}^{-1}$ de PCB), R4,5 (reator com 4,5 mg.L $\mathrm{L}^{-1}$ de PCB) e R6,0 (reator com 6,0 mg.L $\mathrm{L}^{-1}$ de PCB).

Verificou-se nos ensaios de inibição metanogênica que quanto maior a concentração do PCB, menor foi a produção de metano e maior sua inibição nas populações metanogênicas (Figura 5-15). O valor de $\mathrm{IC}_{50}$ dos seis congêneres estudado foi calculado a partir da curva de Dose-resposta ajustada ao gráfico de \% $\mathrm{I}_{\mathrm{M}}$ e produção máxima de metano versus concentração de $\mathrm{PCB}$, sendo obtido $0,03 \mathrm{mg} \cdot \mathrm{L}^{-1}$. Desse modo, $50 \%$ da produção de metano foi afetada para $0,03 \mathrm{mg} \cdot \mathrm{L}^{-1}$ dos seis congêneres de PCB adicionados nos reatores em batelada. Sierra-Alvarez; Lettinga (1991) avaliaram a inibição metanogênica com 34 diferentes compostos aromáticos, e concluíram que o pentaclorofenol foi o mais inibidor, com $\mathrm{IC}_{50}$ de $7,99 \mathrm{mg} . \mathrm{L}^{-1}$. Por meio dos resultados obtidos neste trabalho pode-se inferir que o PCB é um composto toxico para a comunidade metanogênica.

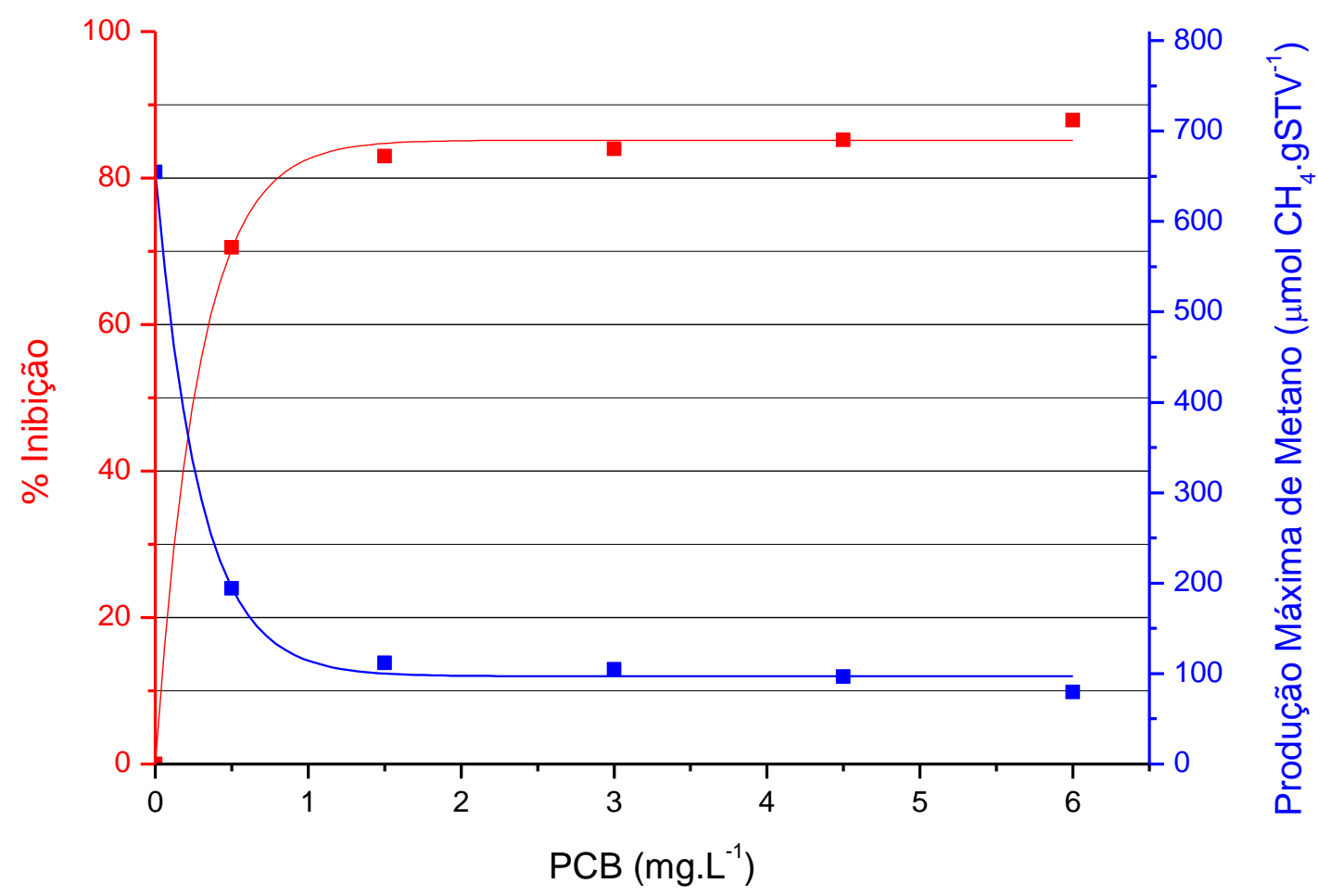

Figura 5-15. Relação entre porcentagem de inibição (-ø-) e produção máxima de metano (-口-) versus a concentração de PCB. Símbolo representa dados mensurados e linha representa o ajuste dos dados à equação.

A comunidade microbiana do inóculo (i), do reator controle (RC), R0.5 (0,5 mg. $\mathrm{L}^{-1}$ de PCB), R1.5 (1,5 mg.L ${ }^{-1}$ de PCB), R3.0 (3,0 mg.L ${ }^{-1}$ de PCB), R4.5 (4,5 mg.L - $^{-1}$ de PCB) e R6.0 (6,0 mg.L - $^{-1}$ de 
PCB) para o Domínio Archaea e Bacteria foram analisadas em termos de composição e diversidade. A correlação filogenética estabelecida e suas respectivas similaridades estão apresentadas na Figura 5-16 [a] e [b]. A diversidade bacteriana estabelecida a partir dos perfis de DGGE de cada amostra foi medida como índice de diversidade de Shannon-Wiener (H').

Verificou-se mediante análise de cluster do perfil de bandas do DGGE, que a biomassa dos reatores anaeróbios em batelada afiliaram-se influenciadas pela concentração do PCB. Para o Domínio Archaea observou-se índice de similaridade de $96 \%$ para a biomassa dos reatores anaeróbios com maior concentração de PCB (R4,5 e R6,0). Sob tais condições verificou-se, menores taxas de produção específica de metano, de 96,7 $\mu \mathrm{molCH}_{4} \cdot \mathrm{gSTV}^{-1}$ e 79,5 $\mu \mathrm{molCH}_{4} \cdot \mathrm{gSTV}^{-1}$, respectivamente (Figura 5-16 [a]). Coeficiente de similaridade de $98 \%$ foi verificado para o Domínio Archaea para biomassa dos reatores anaeróbios com menor concentração de PCB (R0,5 e R1,5). Sob tais condições verificou-se as maiores taxas de produção específica de metano na presença de PCB, de 93,1 $\mu \mathrm{molCH}_{4} . \mathrm{gSTV}^{-1}$ e 111,6 $\mu \mathrm{molCH}_{4} \cdot \mathrm{gSTV}^{-1}$, respectivamente.

Por meio da análise de cluster para o Domínio Bacteria verificou-se três grupos relacionados diretamente com a concentração do PCB nos reatores anaeróbios (Figura 5-16 [b]). Similaridade de 87\% foi observada entre o inóculo e a biomassa do reator RC. Para biomassa dos reatores R0,5 e R1,5 foi observado índice de similaridade de 93\%. Por fim, para aquelas dos reatores R3,0 e R4,5 verificou-se similaridade de $95 \%$.

Ainda, em relação as populações do Domínio Bacteria verificou-se padrões de bandas exclusivos para cada concentração de PCB. As bandas predominantes nos reatores R3,0 e R4,5 foram diferentes daquelas observadas para os reatores R0,5 e R1,5. Já para as amostras do inóculo e do reator RC, não foi observado nenhum padrão de bandas dominante. Provavelmente, a dominância de determinada população foi diretamente relacionada com a concentração de PCB.

Deve-se salientar que verificou-se elevada similaridade (95\%) para as populações do Domínio Bacteria para os reatores R3,0 e R4,5. Destaca-se contudo que foi verificado atividade acidogênica diferente, para as duas condições. Estes resultados podem ser explicados pelo possível estado de inativação das bactérias acidogênicas no reator R4,5, o qual não houve produção do metabólitos (ácidos orgânicos), entretanto ainda estavam presentes na amostra (VAN BODEGOM, 2007).

Menores índices de similaridade para o Domínio Bacteria (81\%) foram observados para as amostras do reator R6,0 em relação as demais biomassas (inóculo e reatores $\mathrm{RC}, \mathrm{R} 0,5, \mathrm{R} 1,5, \mathrm{R} 3,0$ e R4,5). Cámara et al. (2004) demonstraram que altas concentrações de PCB e seus intermediários afetaram a viabilidade da célula, levando à lise celular. Desse modo, provavelmente a baixa produção de ácidos orgânicos e a baixa similaridade obtida para as populações do reator R6,0 em relação as demais biomassas esteja relacionado com tais características. 


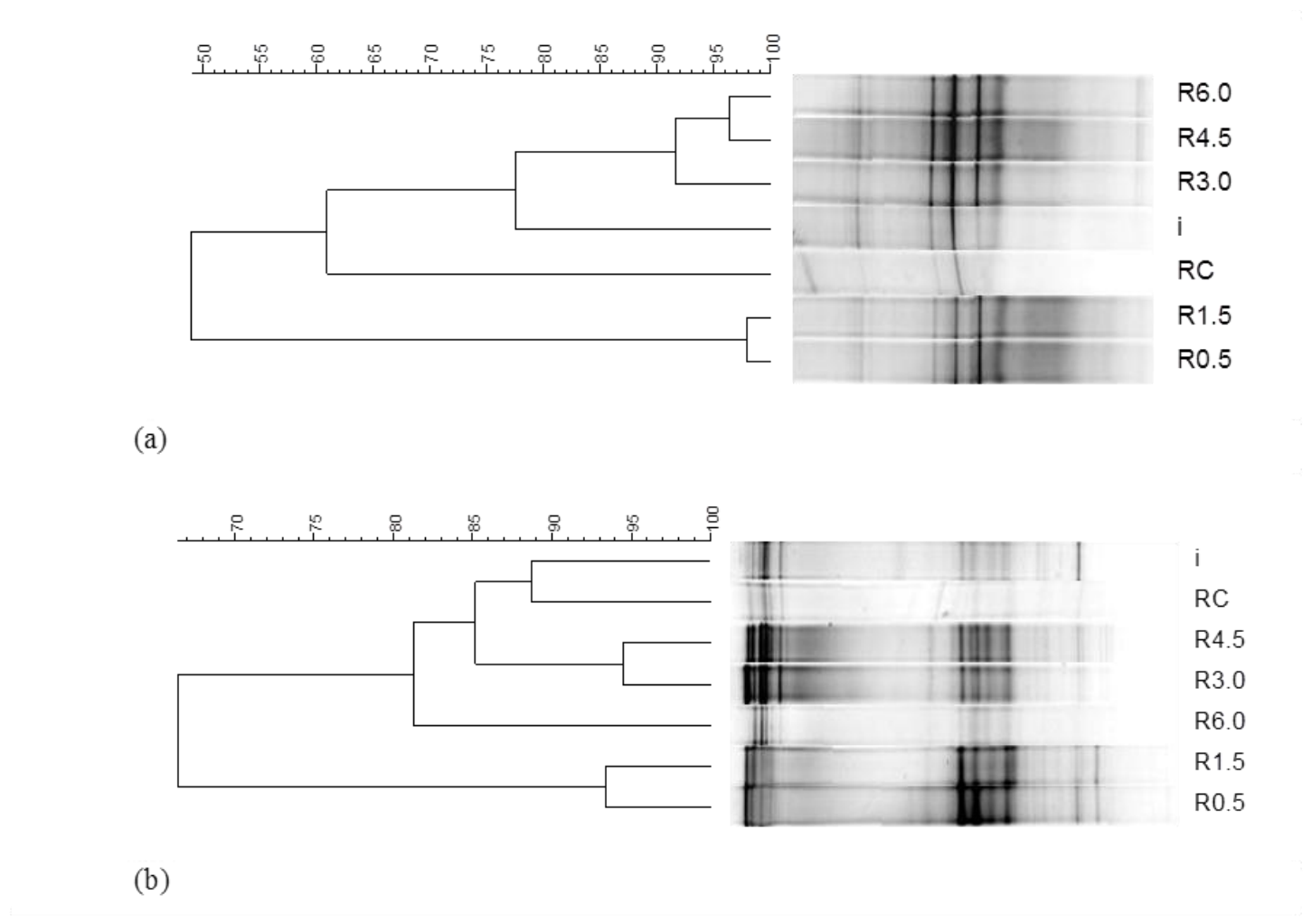

Figura 5-16 Perfis de DGGE de comunidades microbianas em RC (reator controle), i (inóculo), R0.5 (0,5

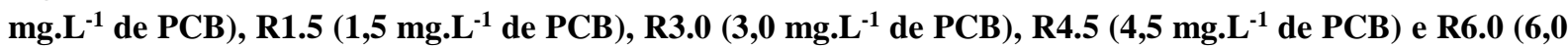
mg. $L^{-1}$ de PCB) para o Domínio Archaea (a) e Bacteria (b). Dendrogama construído utilizando correlação de Pearson e o método de agrupamento UPGMA.

Verificou-se para o Domínio Archaea índice de diversidade de Shannon-Wienner (H') similar para a biomassa presente no inóculo e no reator $\mathrm{RC}$ (2,25 e 2,20, respectivamente) (Tabela 5-14). Ainda para o Domínio Archaea verificou-se índices de similaridade semelhantes entre as biomassas dos reatores R0,5, R1,5, R3,0, R4,5 e R6,0 (2,62, 2,54, 2,40, 2,66 e 2,41, respectivamente) (Tabela 5-14). A partir desses resultados pode-se inferir que a presença de PCB afetou diretamente a diversidade microbiana da biomassa anaeróbia.

Entretanto, para o Domínio Bacteria verificou-se divergência entre a biomassa das amostras, cujos valores obtidos foram 2,85, 3,50, 3,02, 2,81, 2,83, 2,91 e 2,40 para o inóculo, reatores RC, R0,5, $\mathrm{R} 1,5, \mathrm{R} 3,0, \mathrm{R} 4,5$ e R6,0, respectivamente. A partir desses resultados, pode-se evidenciar menor diversidade microbiana na biomassa presente no reator R6,0 quando comparadas com as amostras do inóculo e dos reatores RC, R0,5, R1,5, R3,0 e R4,5, demonstrando o efeito negativo de 6,0 mg. $\mathrm{L}^{-1}$ de PCB sob a comunidade bacteriana anaeróbia.

Tabela 5-14 Índice de diversidade de Shannon-Wienner (H') para as amostras provenientes dos reatores e do inóculo.

\begin{tabular}{l|cccccccc} 
& $\mathrm{i}$ & $\mathrm{RC}$ & $\mathrm{R} 0,5$ & $\mathrm{R} 1,5$ & $\mathrm{R} 3,0$ & $\mathrm{R} 4,5$ & $\mathrm{R} 6,0$ \\
Archaea & 2,25 & 2,20 & 2,62 & 2,54 & 2,40 & 2,66 & 2,41 \\
\cline { 2 - 9 } Bacteria & 2,85 & 3,50 & 3,02 & 2,81 & 2,83 & 2,91 & 2,40 \\
\hline
\end{tabular}




\subsection{Ensaio de Remoção de PCB sob condição fermentativa-metanogênica}

\subsubsection{Parâmetros de Monitoramento}

No Ensaio de Remoção de PCB foi avaliado o consumo de PCB sob condição metanogênica. Os reatores em batelada foram operados por 101 dias. Ao longo do tempo de operação foi avaliada a produção específica de metano nos reatores em batelada, bem como, o consumo de matéria orgânica e produção de ácidos orgânicos voláteis. Nos reatores controle (CM), inoculados com biomassa inativada por tratamento térmico, não foi verificada produção de metano.

A produção de metano nos reatores metanogênicos $(\mathrm{M})$, inoculados com a biomassa ativa, foram ajustados à equação modificada de Gompertz $\left(\mathrm{R}^{2}\right.$ igual a 0,95$)$ (Figura 5-17). A produção máxima de metano calculada a partir da equação ajustada foi de $120,70 \mu$ molCH$_{4} \cdot \mathrm{gSTV}^{-1}$.

No Ensaio de Inibição Metanogênica, a produção máxima de metano de 111,65 $\mu \mathrm{molCH}_{4} \cdot \mathrm{gSTV}^{-}$ ${ }^{1}$ foi obtida para o reator R1,5, operado sob condições similares $\left(1,5 \mathrm{mg} . \mathrm{L}^{-1} \mathrm{de} \mathrm{PCB}\right.$, etanol e formiato como co-substratos e biomassa anaeróbia).

Comparando os resultados de produção máxima de metano obtidos nesse ensaio $\left(120,70 \mu \mathrm{molCH}_{4} . \mathrm{gSTV}^{-1}\right)$ e no Ensaio de Inibição Metanogênica $\left(111,65 \mu \mathrm{molCH}_{4} \cdot \mathrm{gSTV}^{-1}\right)$ foi possível observar respostas metabólicas semelhantes na presença de $1,5 \mathrm{mg} . \mathrm{L}^{-1}$ de PCB.

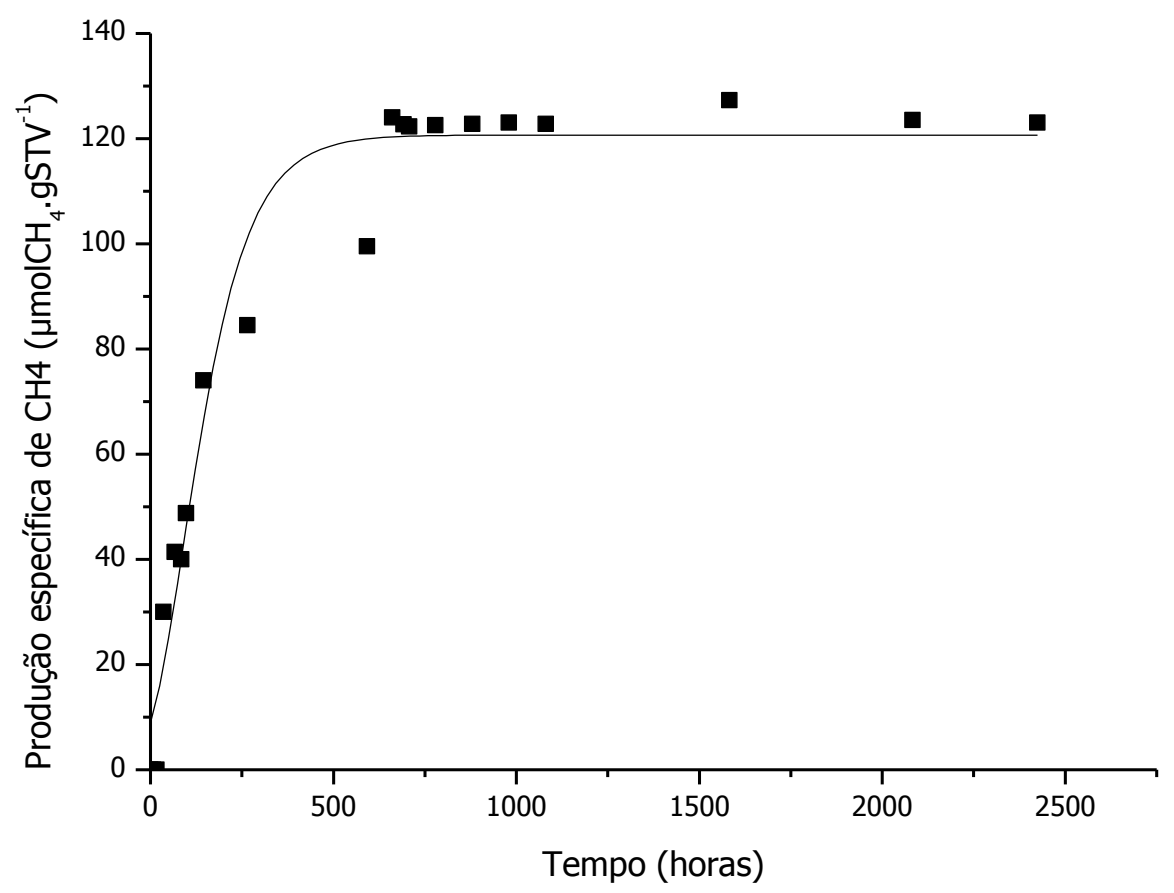

Figura 5-17 Produção específica de metano no Ensaio de Remoção de PCB. Ajuste de Gompertz modificado. Símbolos representam valores medidos, enquanto linha representa o ajuste da equação. 
Verificou-se comportamento similar da produção de metano para a remoção de matéria orgânica neste ensaio. Nos reatores controles (CM) não foi evidenciado consumo de matéria orgânica (Tabela 5-15). Já nos reatores metanogênicos (M), inoculados com biomassa ativa, a eficiência de remoção de DQO observada foi de $48 \%$ para os primeiros 81 dias e $90 \%$ no final do experimento (101 dias) para 2.292,60 mg.L $\mathrm{L}^{-1}$ inicial (Tabela 5-15). Para o reator em condições experimentais semelhantes $(\mathrm{R} 1,5)$ do Ensaio Inibição Metanogênica verificou-se remoção de DQO de 52\% para DQO inicial de $2.247 \mathrm{mg} . \mathrm{L}^{-}$ ${ }^{1}$ em 30 dias de operação.

Comparando-se os resultados de remoção de matéria orgânica obtidos no Ensaio de Remoção de PCB (48\% em 81 dias e 90\% em 101 dias para 2.292,60 mg.L.-1 DQO inicial) e no Ensaio de Inibição Metanogênica (52\% com DQO inicial de $2.247 \mathrm{mg} . \mathrm{L}^{-1} \mathrm{em} 30$ dias) foi possível observar maior remoção de matéria orgânica nas condições impostas para o presente ensaio. Provavelmente, a maior eficiência obtida tenha sido devido ao maior tempo de operação dos reatores anaeróbios, ou seja de 101 dias. Ademais, é possível observar que nos primeiros dias a remoção de matéria orgânica foi menos eficiente, demonstrando uma possível fase de adaptação da biomassa a presença do PCB.

Constatou-se ainda nesse trabalho diferentes concentrações e distribuição de ácidos orgânicos voláteis em cada reator ao longo do tempo de operação (Tabela 5-15). Observou-se concentração de ácidos orgânicos voláteis totais decrescente com o tempo de operação dos reatores metanogênicos MT0,

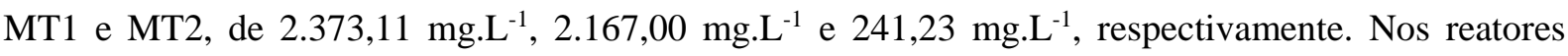
controles, CMT0, CMT1 e CMT2, verificou-se produção de ácidos orgânicos voláteis de 1.671,58 mg.L${ }^{1}, 1.961,00 \mathrm{mg} . \mathrm{L}^{-1}$ e $1.765,63 \mathrm{mg} . \mathrm{L}^{-1}$, respectivamente.

Tabela 5-15 Ácidos orgânicos voláteis, DQO e eficiência de remoção de DQO em cada reator no Ensaio de Remoção de PCB.

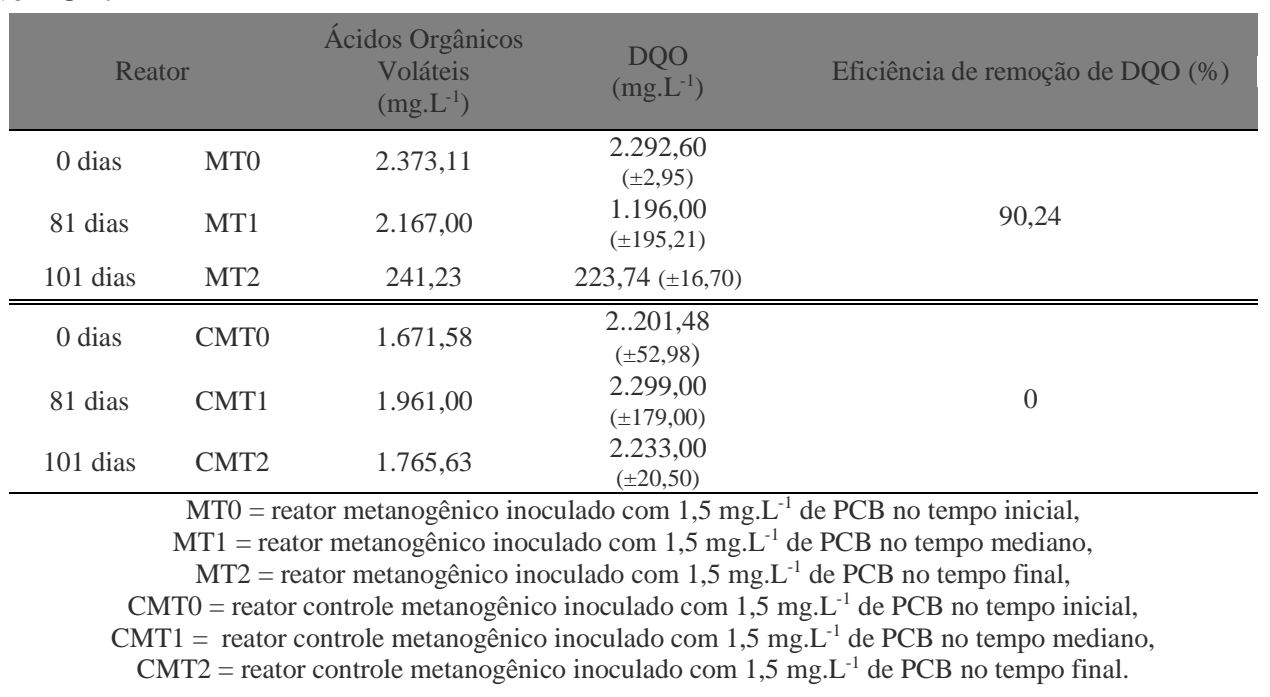

Pode-se inferir a partir da proporção dos ácidos orgânicos voláteis observados nos reatores CM (Tabela 5-16 e Figura 5-18) que as fontes de co-substratos (etanol e formiato de sódio) não foram totalmente consumidas, sendo observado $1.481,9 \mathrm{mg} . \mathrm{L}^{-1}$, 1.289,9 mg. $\mathrm{L}^{-1}$ e $372,1 \mathrm{mg} . \mathrm{L}^{-1}$ para CMT0, CMT1 e CMT2, respectivamente. Em relação à proporção dos ácidos orgânicos voláteis nos reatores $M$ (Figura 5-18) pode-se inferir que o etanol e formiato de sódio adicionados nos sistema foram 
consumidos, sendo obtidos 2.341,3 mg.L $\mathrm{L}^{-1}$, 25,0 mg.L $\mathrm{L}^{-1}$ e 25,7 mg.L $\mathrm{L}^{-1}$ para MT0, MT1 e MT2, respectivamente.

Ácido acético foi o principal composto produzido no reator M, de 1.077,9 mg.L $\mathrm{L}^{-1}$ e 70,9 mg.L $\mathrm{L}^{-1}$, com 81 dias (MT1) e 101 dias de operação (MT2), respectivamente. No Ensaio de Inibição Metanogênica, no reator sob condições similares $(\mathrm{R} 1,5)$ verificou-se que o ácido acético foi o principal composto, com 793,6 mg.L $\mathrm{L}^{-1}$ em 30 dias de operação.

Comparando-se a concentração de ácido acético observada nesse ensaio (1.077,9 mg.L $\mathrm{L}^{-1} \mathrm{em} 81$ dias e 70,9 mg.L $\mathrm{L}^{-1} \mathrm{em} 101$ dias) e no Ensaio de Inibição Metanogênica (793,6 mg.L-1 em 30 dias) foi possível verificar a predominância desse ácido no sistema para as condições com $1,5 \mathrm{mg} \cdot \mathrm{L}^{-1}$ de PCB nos reatores anaeróbios. 
Tabela 5-16 Concentração e porcentagem de cada ácido orgânico volátil nos reatores MT0 (reator metanogênico no tempo inicial), MT1 (reator metanogênico em 81 dias de operação), MT2 (reator metanogênico em 101 dias de operação), CMT0 (reator controle metanogênico no tempo inicial), CMT1 (reator controle metanogênico em 81 dias de operação) e CMT2 (reator controle metanogênico em 101 dias de operação).

\begin{tabular}{|c|c|c|c|c|c|c|c|c|c|c|}
\hline Amostra & Unidade & Etanol & $\begin{array}{c}\text { n- } \\
\text { Butanol }\end{array}$ & $\begin{array}{c}\text { Ac. } \\
\text { Acético }\end{array}$ & $\begin{array}{c}\text { Ac. } \\
\text { Propiônico }\end{array}$ & $\begin{array}{c}\text { Ac. } \\
\text { Isobutírico }\end{array}$ & $\begin{array}{c}\text { Ac. } \\
\text { Butírico }\end{array}$ & $\begin{array}{c}\text { Ac. } \\
\text { Isovalérico }\end{array}$ & $\begin{array}{c}\text { Ac. } \\
\text { Valérico }\end{array}$ & $\begin{array}{c}\text { Ac. } \\
\text { Capróico }\end{array}$ \\
\hline MT0 & mg. $\mathrm{L}^{-1}$ & 2341,35 & 0,00 & 0,00 & 0,00 & 0,00 & 0,00 & 22,18 & 0,00 & 9,57 \\
\hline MT1 & mg. $\mathrm{L}^{-1}$ & 0,00 & 0,00 & 1077,91 & 689,70 & 112,67 & 59,35 & 163,10 & 24,38 & 14,88 \\
\hline MT2 & $\mathrm{mg} . \mathrm{L}^{-1}$ & 25,66 & 0,00 & 70,68 & 42,86 & 0,00 & 29,82 & 56,55 & 15,27 & 10,38 \\
\hline MT0 & $\%$ & 98,66 & 0,00 & 0,00 & 0,00 & 0,00 & 0,00 & 0,93 & 0,00 & 0,40 \\
\hline MT1 & $\%$ & 0,00 & 0,00 & 50,32 & 32,20 & 5,26 & 2,77 & 7,61 & 1,14 & 0,69 \\
\hline MT2 & $\%$ & 10,22 & 0,00 & 28,14 & 17,06 & 0,00 & 11,87 & 22,51 & 6,08 & 4,13 \\
\hline CMT0 & mg.L. ${ }^{-1}$ & 1481,88 & 0,00 & 75,50 & 21,93 & 24,73 & 19,01 & 23,49 & 15,83 & 9,22 \\
\hline CMT1 & $\operatorname{mg} . L^{-1}$ & 1289,94 & 7,54 & 542,76 & 27,27 & 23,86 & 16,62 & 28,77 & 15,25 & 8,96 \\
\hline СMT2 & mg.L $L^{-1}$ & 372,10 & 7,50 & 1137,60 & 141,01 & 0,00 & 18,10 & 54,05 & 26,23 & 9,03 \\
\hline CMT0 & $\%$ & 88,65 & 0,00 & 4,52 & 1,31 & 1,48 & 1,14 & 1,41 & 0,95 & 0,55 \\
\hline CMT1 & $\%$ & 65,78 & 0,38 & 27,68 & 1,39 & 1,22 & 0,85 & 1,47 & 0,78 & 0,46 \\
\hline CMT2 & $\%$ & 21,07 & 0,42 & 64,43 & 7,99 & 0,00 & 1,03 & 3,06 & 1,49 & 0,51 \\
\hline
\end{tabular}

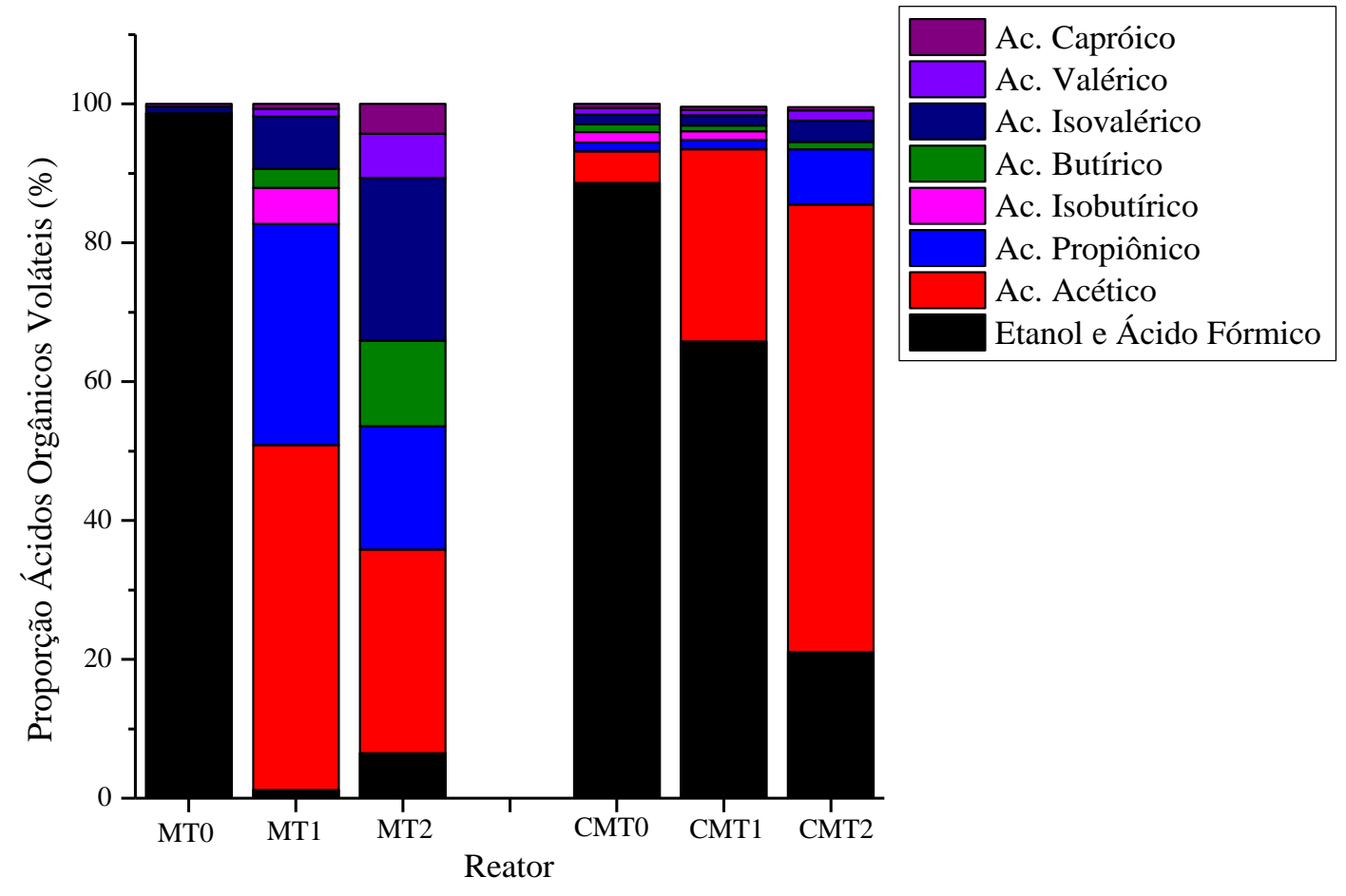


Figura 5-18 Proporção de cada ácido orgânico volátil nos reatores MT0 (reator metanogênico no tempo inicial), MT1 (reator metanogênico em 81 dias de operação), MT2 (reator metanogênico em 101 dias de operação), CMT0 (reator controle metanogênico no tempo inicial), CMT1 (reator controle metanogênico em 81 dias de operação) e CMT2 (reator controle metanogênico em 101 dias de operação).

\subsubsection{Remoção de PCB}

O método de adição do padrão, ou Standard addiction foi utilizado para quantificar o PCB proveniente de amostras dos reatores a fim de minimizar o efeito de matriz das amostras. A remoção do PCB sob condição anaeróbia foi avaliada nos reatores metanogênicos (M) (Figura A. 1 a Figura A. 6, apêndice) no tempo inicial (T0), com 81 dias de operação (T1) e no tempo final, com 101 dias de operação (T2). Para as condições controle (CM) (Figura A. 7 a Figura A. 12, apêndice) foi avaliada a concentração de PCB no tempo inicial (T0) e no tempo final, com 101 dias de operação (T2).

A remoção de poluentes orgânicos em reatores biológicos envolve, tanto o mecanismo de biodegradação, quanto de biossorção (TSEZOS; BELL, 1989). A biodegradação é a degradação destes compostos intermediada pelos microrganismos disponíveis no inóculo, e a biossorção, é a adsorção dos poluentes na biomassa dos reatores (TSEZOS; BELL, 1989).

Uma vez que a determinação de parâmetros de biossorção para a biomassa inativada, ou morta, é tecnicamente mais fácil do que para a biomassa ativa (TSEZOS; BELL, 1988), é vantajosa a utilização de biomassa inativa para determinar os parâmetros necessários de biossorção.

A cinética de biossorção por meio de isotermas não foi avaliado neste trabalho, entretanto, a análise de biossorção foi avaliada por meio da análise da concentração dos congêneres de PCB nos reatores controle (CM), inoculados com biomassa inativada no tempo inicial (T0) e final de operação (T2) (Tabela 5-17). Destaca-se que foi verificado para cada congênere concentração constante ao longo do tempo, sendo o valor de adsorção calculado a partir dessas concentrações e da concentração teórica adicionada de cada congênere $\left(1,5 \mathrm{mg} \cdot \mathrm{L}^{-1}\right)$.

Observou-se diferentes concentrações iniciais para cada congênere (Tabela 5-17). Verificou-se concentrações mais elevadas para os congêneres PCB 10, 138 e 180, de 0,92 mg.L. $\mathrm{L}^{-1}, 0,77 \mathrm{mg} . \mathrm{L}^{-1} \mathrm{e}$ $0,93 \mathrm{mg} . \mathrm{L}^{-1}$, respectivamente. Em contrapartida, notou-se concentrações menores para o PCB $28,52 \mathrm{e}$ 153, de 0,39 mg.L $\mathrm{L}^{-1}, 0,32 \mathrm{mg} . \mathrm{L}^{-1}$ e $0,16 \mathrm{mg} . \mathrm{L}^{-1}$, respectivamente.

Comparando-se as diferentes concentrações dos congêneres de PCB observadas foi possível inferir que exista diferentes afinidades desses congêneres de PCB com a biomassa. A diferença entre as concentrações biossorvidas pode ser explicada pelo variado número de átomos de cloro em cada molécula e posição no anel, o qual confere distintas conformações moleculares e características particulares a cada congênere.

Patureau; Trably (2006) verificaram para lodos anaeróbios maior capacidade de induzir perdas abióticas de PCB. Os autores observaram entre 10 a 30\% de perda para os PCB 52, 101, 118, 138, 153 e 180. Neste trabalho foram encontrados valores de biossorção de $38 \%, 74 \%, 78 \%, 89 \%$, $48 \%$ e $37 \%$ para as PCBs 10, 28, 52, 153, 138 e 180, respectivamente. Provavelmente, as diferenças observadas neste trabalho em relação aos resultados de Patureau e Trably (2006) estejam relacionadas com a 
influência na adsorção, tanto da estrutura molecular do PCB (PATUREAU; TRABLY, 2006), quanto das características da biomassa usada como inóculo dos reatores anaeróbios (TSEZOS; WANG, 1991).

Ademais, como já no tempo inicial de operação (T0) a biossorção foi evidenciada, foi possível inferir que o PCB foi prontamente adsorvido na biomassa. Resultados similares foram observados por Tsezos; Wang (1991), que avaliaram a adsorção do PCB 1 em lodos ativados. Os autores observaram alta velocidade de adsorção, em quatro horas o PCB em solução atingiu equilíbrio com o PCB adsorvido na biomassa.

Tabela 5-17 Concentração dos seis congêneres de PCB (PCB 10, 28, 52, 153, 138 e 180) nos reatores controle (CM) ao longo do tempo de operação (T0 e T2) do ensaio em batelada.

\begin{tabular}{|c|c|c|c|c|c|c|}
\hline & $\frac{\mathrm{PCB} 10}{\mathrm{CM}^{1}}$ & $\frac{\mathrm{PCB} 28}{\mathrm{CM}^{1}}$ & $\frac{\mathrm{PCB} 52}{\mathrm{CM}^{1}}$ & $\frac{\mathrm{PCB} 153}{\mathrm{CM}^{1}}$ & $\frac{\mathrm{PCB} 138}{\mathrm{CM}^{1}}$ & $\frac{\mathrm{PCB} 180}{\mathrm{CM}^{1}}$ \\
\hline T0 & 0,92 & 0,39 & 0,32 & 0,16 & 0,77 & 0,93 \\
\hline $\mathrm{T} 2$ & 0,93 & 0,38 & 0,32 & 0,17 & 0,77 & 0,94 \\
\hline Biossorção ${ }^{2}$ & 0,58 & 1,12 & 1,18 & 1,34 & 0,73 & 0,57 \\
\hline \% biossorção & 38,33 & 74,33 & 78,67 & 89,00 & 48,67 & 37,67 \\
\hline
\end{tabular}

Fazer uma generalização relativa à magnitude de adsorção entre a biomassa e compostos orgânicos é um problema de difícil resolução. Entretanto, pelos resultados observados, por meio da análise de adsorção de PCB nas condições dos reatores controle pode-se inferir que ocorreu remoção e degradação de PCB nos reatores metanogênicos. Verificou-se remoção de PCB nos reatores metanogênicos (M) de no mínimo 0,92 mg. $\mathrm{L}^{-1}, 0,19 \mathrm{mg} \cdot \mathrm{L}^{-1}, 0,18 \mathrm{mg} \cdot \mathrm{L}^{-1}, 0,07 \mathrm{mg} \cdot \mathrm{L}^{-1}, 0,55 \mathrm{mg} \cdot \mathrm{L}^{-1}$ e 0,47 mg.L $\mathrm{L}^{-1}$ para os PCBs 10, 28, 52, 153, 138 e 180, respectivamente (Tabela 5-18), com remoção média de PCBs totais de $0,40 \mathrm{mg} . \mathrm{L}^{-1}(81,5 \%)$.

Gomes et al. (2014) evidenciaram degradação dos seis congêneres de PCB (10, 28, 52, 153, 138 e 180) em reatores em batelada inoculado com lodo anaeróbio na presença de co-substratos (formiato de sódio e etanol). A partir da concentração inicial de $0,7 \mathrm{mg} . \mathrm{L}^{-1}$ para cada congênere, os autores observaram remoção de $0,12 \mathrm{mg} . \mathrm{L}^{-1}, 0,37 \mathrm{mg} . \mathrm{L}^{-1}, 0,43 \mathrm{mg} . \mathrm{L}^{-1}, 0,45 \mathrm{mg} \cdot \mathrm{L}^{-1}, 0,46 \mathrm{mg} \cdot \mathrm{L}^{-1}$ e $0,40 \mathrm{mg} \cdot \mathrm{L}^{-1}$ para os PCBs 10, 28, 52,153, 138 e 180, respectivamente.

Comparando os resultados observados por Gomes et al. (2014) e aqueles reportados neste trabalho pode-se evidenciar que a remoção foi distinta para cada congênere. A distinta remoção de PCB pode ter ocorrido por diferença na comunidade microbiana proveniente do inóculo (ocasionado por diferenças na conservação e manutenção de lodo), bem como, pela diferença da concentração de PCB usada nas diferentes pesquisas, ou seja, $0,7 \mathrm{mg} . \mathrm{L}^{-1}$ e 1,5 mg.L $\mathrm{L}^{-1}$, respectivamente, em Gomes et al. (2014) e nesta pesquisa. Barret et al. (2010) afirmaram que a remoção de poluentes em biorreatores é dependente do metabolismo microbiano e biodisponibilidade do composto.

Tabela 5-18 Concentração dos seis congêneres de PCB (PCB 10, 28, 52, 153, 138 e 180) nos reatores metanogênicos (M) ao longo do tempo de operação (T0, T1 e T2) do ensaio em batelada.

\begin{tabular}{cc|c|c|c|c|c||c} 
& PCB 10 & PCB 28 & PCB 52 & PCB 153 & PCB 138 & PCB 180 & PCBs totais $^{2}$ \\
\hline T0 & 1,01 & 0,42 & 0,24 & 0,11 & 0,55 & 0,59 & 0,49 \\
\hline T1 & 1,05 & 0,30 & 0,26 & 0,08 & 0,02 & 0,12 & 0,30 \\
\hline $\mathrm{T} 2$ & 0,09 & 0,23 & 0,06 & 0,04 & 0 & 0,12 & 0,09 \\
\hline \hline
\end{tabular}




\begin{tabular}{cc|c|c|c|c|c||c}
\hline \hline Remoção $^{1}$ & 0,92 & 0,19 & 0,18 & 0,07 & 0,55 & 0,47 & 0,40 \\
\hline \% remocao & 91,1 & 45,2 & 75,0 & 63,6 & 100,0 & 79,7 & 81,5 \\
\hline & $\begin{array}{r}\text { Concentração de PCB removida em relação ao PCB encontrado inicialmente nos reatores } \\
{ }^{2} \text { Concentração de PCBs totais na amostra: Média dos seis congêneres de PCB }\end{array}$
\end{tabular}

Aos 81 dias de operação dos reatores metanogênicos (T1) verificou-se diminuição acentuada na concentração apenas dos PCBs mais clorados (de $0,11 \mathrm{mg} \cdot \mathrm{L}^{-1}$ a $0,08 \mathrm{mg} \cdot \mathrm{L}^{-1}$ para PCB 153 , de 0,55 mg. $\mathrm{L}^{-1}$ a $0,02 \mathrm{mg} . \mathrm{L}^{-1}$ para o PCB 138 e de $0,59 \mathrm{mg} . \mathrm{L}^{-1}$ a $0,12 \mathrm{mg} . \mathrm{L}^{-1}$ para o PCB 180 ) e ligeiro aumento dos PCBs menos clorados (de 1,01 mg.L $\mathrm{L}^{-1}$ a $1,05 \mathrm{mg} . \mathrm{L}^{-1}$ para o PCB 10 e de $0,24 \mathrm{mg} . \mathrm{L}^{-1}$ a $0,26 \mathrm{mg} . \mathrm{L}^{-1}$ para o PCB 52) (Figura 5-19).

Dudková; Demnerová; Bedard (2012) evidenciaram a desalogenação de hexa-, hepta-, octa- e nonaclorobifenil em tri-, tetra-, penta- e hexaclorobifenil. Essa desalogenação teve como consequência diminuição dos PCB mais clorados e aumento dos menos clorados no meio reacional. Assim, provavelmente nos reatores do presente estudo, os PCBs mais clorados foram removidos pela comunidade anaeróbia e consequentemente, para os PCBs menos clorados, tais como PCB 10 e PCB 52 , verificou-se ligeiro acréscimo.

Entre 81 e 101 dias de operação dos reatores (T1 e T2, respectivamente) verificou-se concentração média constante dos PCBs mais clorados (de 0,08 mg. $\mathrm{L}^{-1}$ a $0,04 \mathrm{mg} . \mathrm{L}^{-1}$ para PCB 153, de 0,02 mg.. $\mathrm{L}^{-1}$ a $0,0 \mathrm{mg} \cdot \mathrm{L}^{-1}$ para o PCB 138 e de $0,12 \mathrm{mg} . \mathrm{L}^{-1}$ a $0,12 \mathrm{mg} \cdot \mathrm{L}^{-1}$ para o PCB 180). Todavia, para os PCBs menos clorado, como PCB 10 e 52, verificou-se decréscimo efetivo de $0,96 \mathrm{mg} . \mathrm{L}^{-1}$ e $0,20 \mathrm{mg} . \mathrm{L}^{-}$ ${ }^{1}$, respectivamente. Desse modo, pode-se inferir que no primeiro período de operação (81 dias) a remoção foi efetiva para os PCBs mais clorados (PCB 153, 138 e 180) e no segundo período de operação (101 dias) foi efetiva para os PCB menos clorados (PCB 10 e 52). 


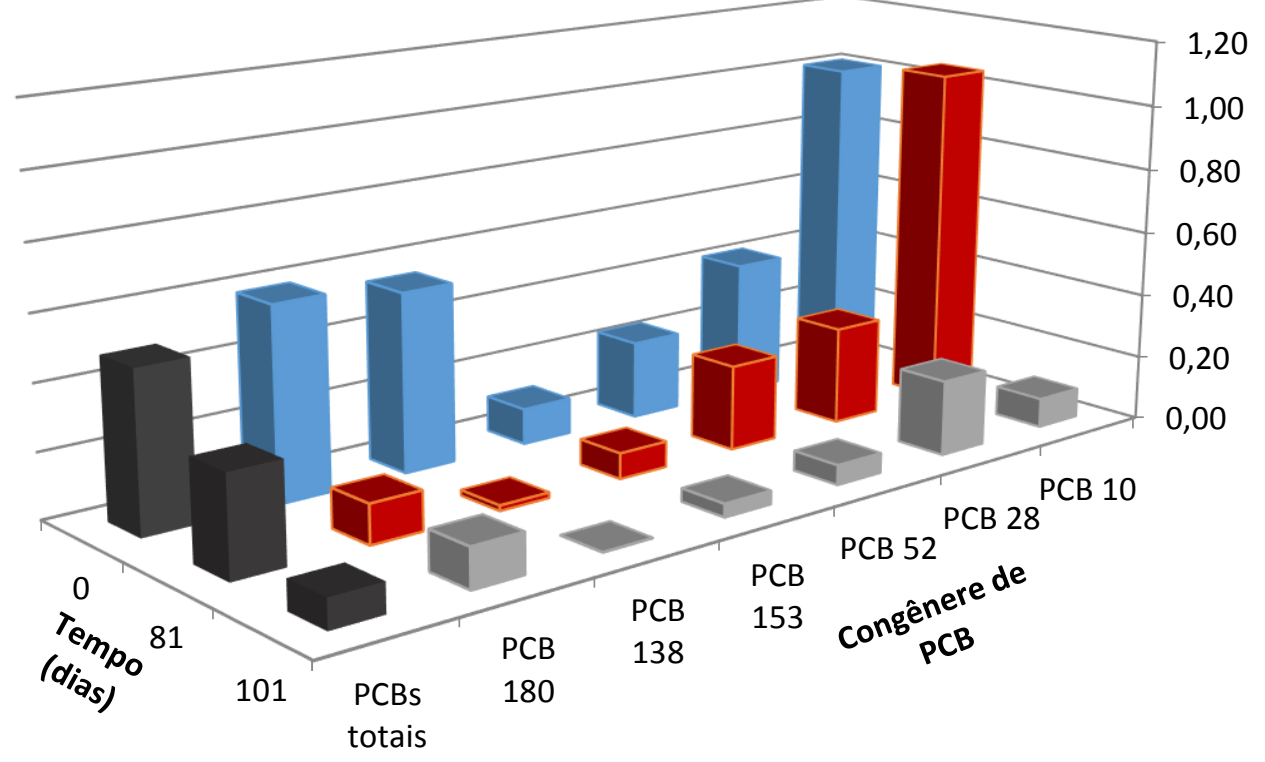

Figura 5-19 Concentração dos seis congêneres de PCB (PCB 10, 28, 52, 153, 138 e 180) e concentração média dos PCBs ( $\bullet$ PCBs totais) nos reatores metanogênicos (M) ao longo do tempo de operação ( $\square$ T0, $\square$ T1 e $\square$ T2) do ensaio em batelada.

\subsection{3 Índices ecológicos}

A região hipervariável V3-V4 do gene RNAr 16S foi utilizada para o sequenciamento massivo das amostras dos reatores metanogênicos referente ao Ensaio de Remoção de PCB. Obteve-se 124.970 de sequências contendo em média 439 pares de base para as duas amostras do início e final da operação dos reatores para representantes do Domínio Bacteria e Archaea (Tabela 5-19).

Dentre as sequencias selecionadas, 58.941 e 66.029 foram atribuídas para amostras do início (MT0) e final de operação (MT2), respectivamente. Ao todo foram definidas 2.313 UTOs (Unidade Taxonômica Operacional), sendo 1.290 das UTOs atribuídas a biomassa do inóculo ou reator anaeróbio no tempo inicial de operação (MT0) e 1.023 das UTOs atribuídas as amostras dos reatores no tempo final de operação (MT2).

Tabela 5-19 Quantidade de sequencias e UTOs atribuídas a cada amostra (97\% de similaridade).

\begin{tabular}{|c|c|c|c|c|}
\hline Amostra & Sequ & cias & & UTOs \\
\hline Inóculo ou reator no tempo inicial de operação (MT0) & $\begin{array}{l}\text { Domínio Bacteria } \\
\text { Domínio Archaea }\end{array}$ & \begin{tabular}{|l}
50.466 \\
7.947
\end{tabular} & 58.941 & $\frac{1.189}{24} 1.290$ \\
\hline \multirow{2}{*}{ Reator no tempo final de operação (MT2) } & Domínio Bacteria & 62.667 & \multirow{2}{*}{66.029} & 898 \\
\hline & Domínio Archaea & 2.049 & & 19 \\
\hline TOTAL & & \multicolumn{2}{|c|}{124.970} & 2.313 \\
\hline
\end{tabular}

Na ecologia de comunidades as medidas de diversidade são agrupadas em três categorias, índice de riqueza (número de espécies), índice de equitabilidade e riqueza (abundância relativa) e modelo de abundância das espécies. Para avaliar a complexidade da comunidade microbiana das amostras dos 
reatores em batelada metanogênico, MT0 e MT2, foram calculados os índices ecológicos de diversidade, dominância, equitabilidade e riqueza (Tabela 5-20).

Por meio da análise do índice de Simpson (1-D), complemento do índice de dominância, foi possível verificar para ambos os domínios valor menor no final do experimento, de 0,92 para 0,88 para o Domínio Archaea, e de 0,96 para 0,89 para representantes do Domínio Bacteria. Pode-se inferir que houve maior dominância de um, ou poucos grupos na comunidade microbiana no final da operação dos reatores em batelada e, provavelmente, ocorreu seleção de microrganismos devido a presença de PCB nos reatores anaeróbios.

Por meio da análise de diversidade através do índice de Shannon-Wienner (H') foi possível verificar que no final da operação (MT2) os valores obtidos foram menores, quando comparados com as amostras iniciais (MT0), tanto para o Domínio Bacteria (de 4,73 para 3,81), quanto Archaea (de 4,24 para 3,58). Por meio dessa análise foi possível inferir que no final da operação dos reatores anaeróbios verificou-se menor diversidade da comunidade microbiana para os representantes de ambos os domínios.

Através da análise de equitabilidade de Pielou (J') verificou-se baixa equitabilidade para a biomassa do final do experimento, de 0,55 para 0,47 e de 0,59 para 0,49, para o Domínio Archaea e Bacteria, respectivamente. A equitabilidade indica abundancia distinta entre as espécies e confirma o índice de dominância encontrado para as amostras, de 0,92 para 0,88 para o Domínio Archaea, e de 0,96 para 0,89 para representantes do Domínio Bacteria.

A cobertura (C) foi utilizada para avaliar se o tamanho da biblioteca de UTOs era suficiente para estimar índices ecológicos confiáveis e significativos. Observou-se valores de C acima de 97\% (98,0\% e 98,5\% para o Domínio Archaea e 97,4\% e 98,1\% para o Domínio Bacteria). Por meio destes resultados pode-se inferir que as espécies de microrganismos identificadas na biblioteca nos garantem boa representatividade da microbiota nas amostras e que os índices ecológicos calculados são confiáveis e significativos (PENG et al., 2012).

Comunidades naturais microbianas normalmente são caracterizadas pela presença de algumas espécies com muitos indivíduos, e muitas espécies com poucos indivíduos. Na presença de um fator limitante pode ocorrer alterações detectáveis na estrutura da comunidade microbiana (WILHM; DORRIS, 1968). Peng et al. (2012) demonstraram que ao se enriquecer uma comunidade com adições temporais de um composto tóxico, como o tetra-bromobisfenol, ocorreu seleção de microrganismos resistentes e capazes de degradar o composto.

Verificou-se para as amostras do final de operação (MT2) tendência a baixos valores de riqueza (1.787 e 2.318 UTOs, para Domínio Archaea e Bacteria, respectivamente), diversidade (3,58 e 3,81, respectivamente para Domínio Archaea e Bacteria) e equitabilidade de espécies $(0,48$ e 0,49, respectivamente para Domínio Archaea e Bacteria), possivelmente resultando em alta dominância e abundância de espécies mais resistentes. Com isso, pode-se indicar a seguinte hipótese: a estrutura da comunidade microbiana é diferente nos reatores com a adição do PCB em relação àquela do inóculo proveniente de reator UASB. 
Tabela 5-20 Índices ecológicos de diversidade, dominância, equitabilidade e riqueza para o Domínio Bacteria e Archaea, nas amostras MT0 e MT2.

\begin{tabular}{ccccc}
\multirow{2}{*}{ Número de Sequencias } & \multicolumn{2}{c}{ Domínio Archaea } & \multicolumn{2}{c}{ Domínio Bacteria } \\
\cline { 2 - 5 } & MT0 & MT2 & MT0 & MT2 \\
\hline UTOs & 60.535 & 67.552 & 60.523 & 67.582 \\
\hline Simpson (1-D) ou Doninância & 2.250 & 1.787 & 2.867 & 2.318 \\
\hline Shannon-Wienner (H') ou Diversidade & $0,922 \pm 0,002$ & $0,885 \pm 0,002$ & $0,96 \pm 0,001$ & $0,889 \pm 0,003$ \\
\hline Pielou (J') ou Equitabilidade & $4,24 \pm 0,03$ & $3,58 \pm 0,02$ & $4,73 \pm 0,03$ & $3,81 \pm 0,03$ \\
\hline Singletons & $0,55 \pm 0,004$ & $0,479 \pm 0,003$ & $0,595 \pm 0,003$ & $0,491 \pm 0,003$ \\
\hline Cobertura (C) & 1.197 & 1.020 & 1.576 & 1.311 \\
\hline
\end{tabular}

Por meio da análise das curvas de rarefação verificou-se maior riqueza para a amostra do reator no tempo inicial (MT0) comparada com aquela obtida no final de operação (MT2) (Figura 5-20). Atribuiu-se, então a menor riqueza da amostra do reator no final da operação (MT2) à presença de PCB e, consequentemente a seleção de microrganismos resistentes a este composto.

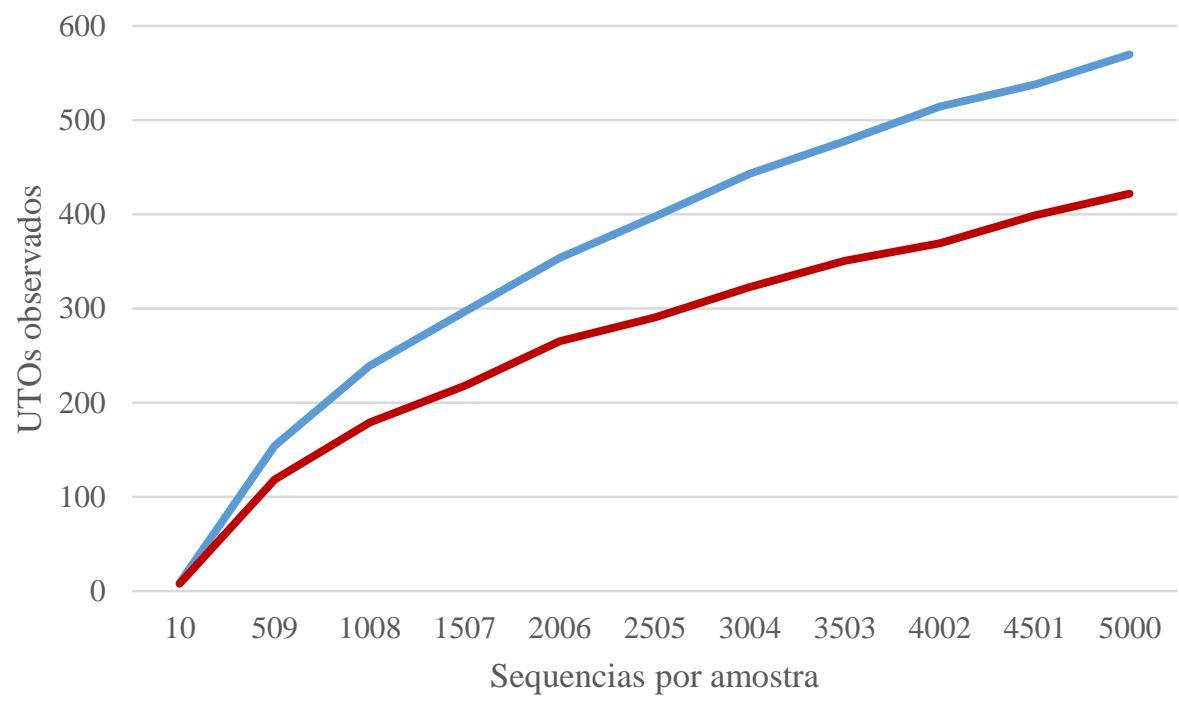

Figura 5-20 Curva de rarefação das sequencias de amostras do inóculo, reator metanogênico no tempo incial (-MT0) e final de operação (-MT2) (97\% de similaridade).

\subsubsection{Análise Taxonômica}

Por meio da aplicação do RDP-classifier obteve-se classificação em filos dos representantes do domínio Bacteria para cada amostra. Em relação aos filos identificados nas amostras iniciais (MT0) e finais (MT2) dos reatores metanogênicos em batelada, destaca-se a similaridade com representantes pertencentes ao filo Proteobacteria (49-30\%), Thermotogae (0,7-30\%), Firmicutes (4-15\%), Chloroflexi (4-8\%) e Synergistetes (7-6\%) (Figura 5-21). 
Em relação a biomassa dos reatores no início (MT0) e final (MT2) de operação dos reatores pode-se salientar que ocorreu alteração na composição dos representantes pertencentes a determinado filo. Ao longo do tempo de operação verificou-se diminuição da abundância relativa de Proteobacteria, de $49 \%$ para $30 \%$, e de Synergistetes, de $7 \%$ para $6 \%$. Em contrapartida, para representantes de outros filos verificou-se aumento da abundância relativa, como por exemplo, para Thermotogae (de $0,7 \%$ para 30\%), Firmicutes, (de 4 para 15\%) e Chloroflexi (de 4\% para 9\%).

Pode-se salientar, ainda, que ocorreu pouca alteração da composição microbiana para os representantes do filo Proteobacteria (Figura 5-21). Ao longo do tempo de operação verificou-se alteração da abundância relativa de Alpha-proteobacteria, (de 4\% para 6\%), Beta-proteobacteria (14\% para 16\%), Delta-proteobacteria (de 13\% para 14\%), Episilon-proteobacteria (de 57\% para 50\%) e Gamma-proteobacteria (de 12\% para 13\%).

Desse modo, pode-se destacar que houve seleção na microbiota dos reatores anaeróbios, e provavelmente relacionada com a adição de PCB, uma vez que, a capacidade das bactérias pertencentes aos filos Chloroflexi e Firmicutes em realizar a desalogenação é conhecida e tem sido descrita com frequência na literatura científica (KITAGAWA; KAMAGATA, 2014). 


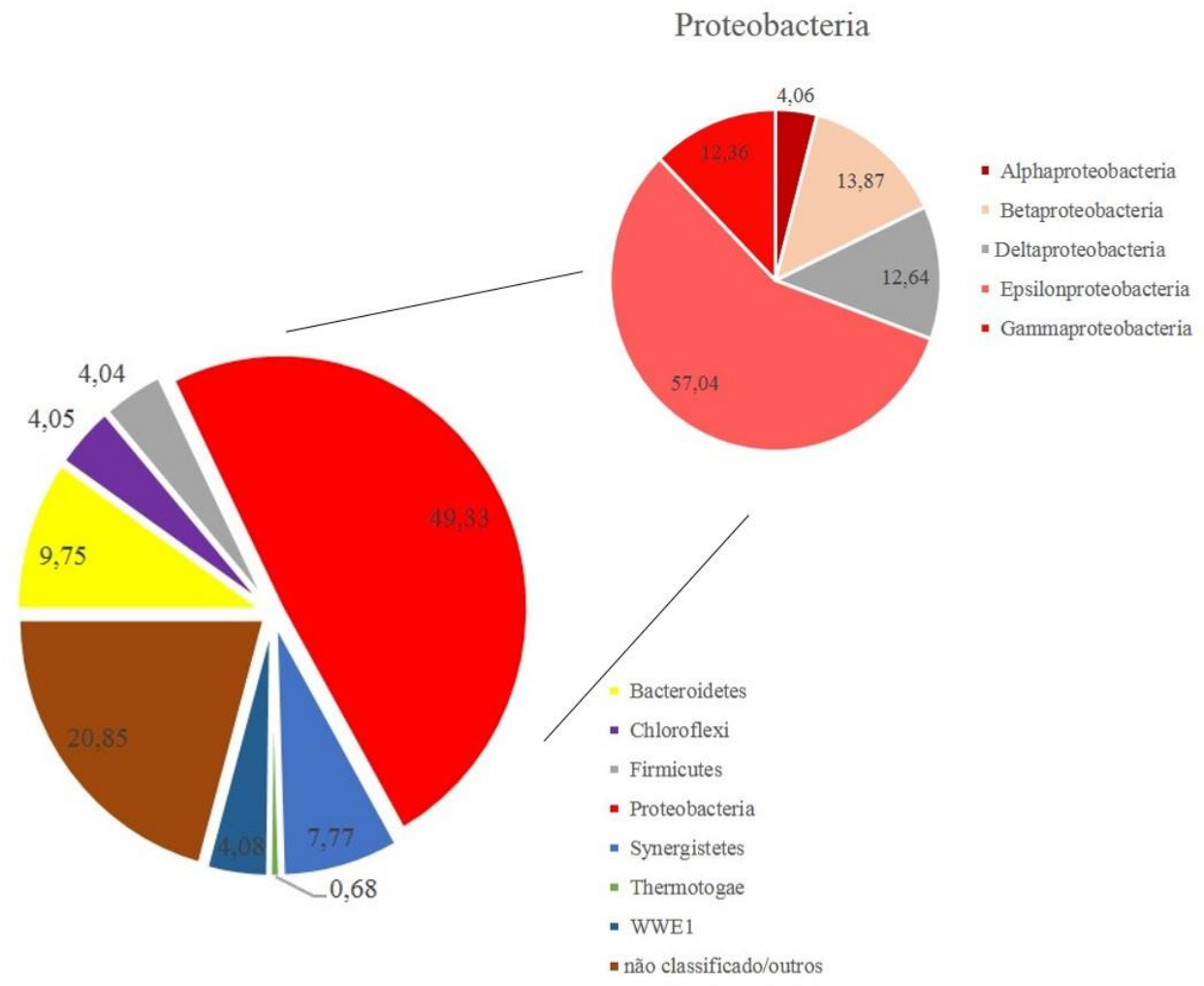

(a)

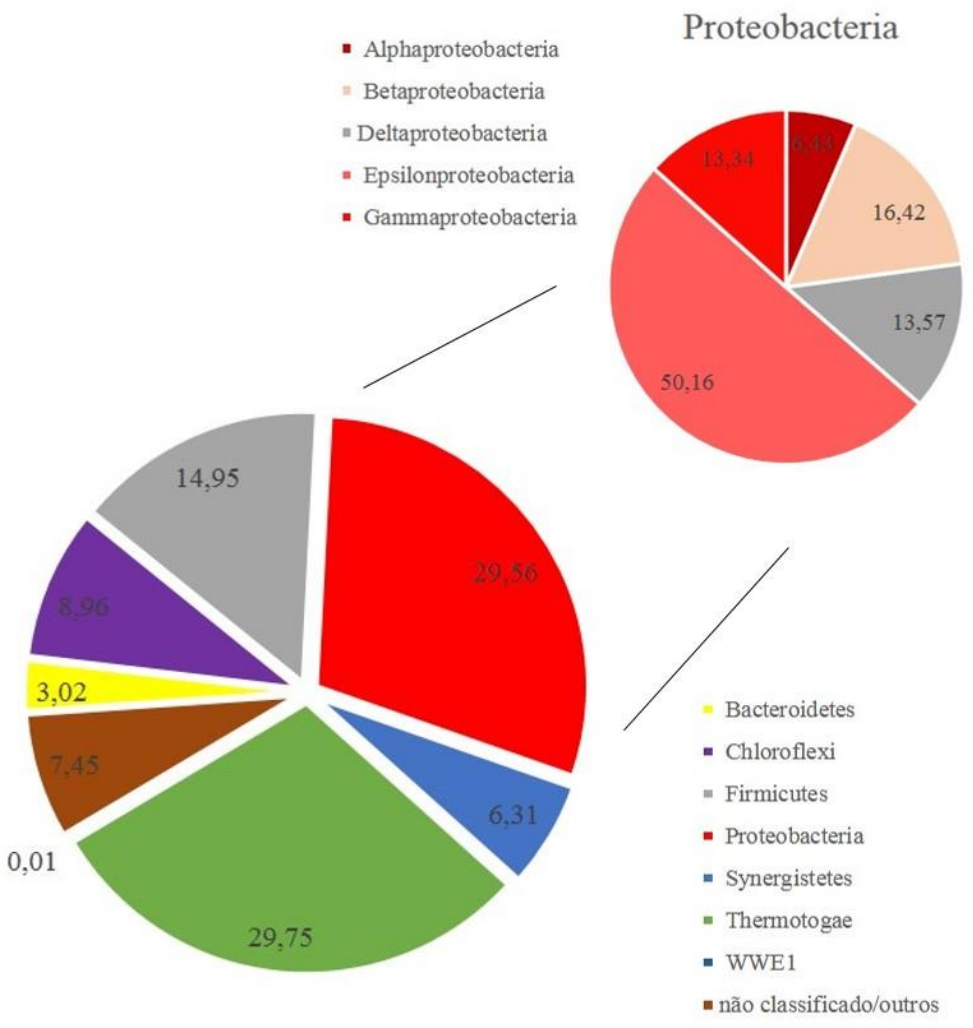

(b)

Figura 5-21 Abundância relativa de classes, dentro do grupo Proteobacteria, e dos filos (similaridade 97\%) nas amostras iniciais MT0 (a) e finais MT2 (b). 
Devido a quantidade de gêneros do Domínio Bacteria classificados (75-180) restringiu-se à descrição dos 10 grupos (ordem, família, gênero e espécie) com maior abundância relativa em cada amostra, MT0 (Tabela A. 1, apêndice) e MT2 (Tabela A. 2, apêndice). A distribuição dos principais grupos identificados nas amostras inicial (MT0) e final (MT2) está apresentada na Figura 5-22.

Dentre esses grupos, dois deles (Sulfurimonas e Cloacamonas) foram identificados apenas no inóculo, e portanto foram relacionados com a pré-existência desses microrganismos no lodo anaeróbio de reator UASB. Apenas um grupo foi identificado (Synergistaceae) nas amostras MT0 e MT1, e foi relacionado com a presença no inóculo e atividade metabólica que favorecia sua manutenção no sistema. Por fim, quatro grupos (Thermotogaceae, Sedimentibacter, Anaerolinaceae e Pseudomonas) foram identificados apenas na amostra MT2, provavelmente, desempenharam papel importante na remoção do PCB.

No inóculo ou reator metanogênico no tempo inicial de operação (MT0), foram identificados representantes semelhantes a Sulfurimonas, caracterizando 26,89\% da microbiota sequenciada. Tal gênero é caracterizado pela anaerobiose facultativa (BOONE et al., 2005) e capacidade de crescer sob condições quimiolitotróficas. Isto significa que os microrganismos deste grupo são capazes de crescer utilizando hidrogênio molecular, enxofre elementar ou tiossulfato como fonte de energia, $\mathrm{CO}_{2}$ como fonte de carbono e amônia ou o nitrato como fonte de nitrogênio (TAKAI et al., 2006).

As próprias características do lodo como a intensa atividade anaeróbia e sua prolongada idade, podem explicar a riqueza observada para Sulfurimonas no inóculo e não no final da operação (MT2). A intensa fermentação acidogênica, bem como a metanogênese, provavelmente, favoreceram elevada produção de elementos mais simples como $\mathrm{CO}_{2}, \mathrm{H}_{2}, \mathrm{NH}_{3}, \mathrm{H}_{2} \mathrm{~S}$ e $\mathrm{CH}_{4}$, possivelmente carreada pelo longo tempo de armazenamento do lodo, onde grande parte da matéria orgânica foi consumida, possibilitando o crescimento de organismos capazes de consumir estes compostos mais simples. Estes microrganismos foram identificados apenas em amostras de sedimentos marinhos e dulcícolas (BRIÉE; MOREIRA; LÓPEZ-GARCÍA, 2007; LIAO; HUANG; HUANG, 2007). A identificação destes microrganismos no presente estudo pode indicar a existência desses microrganismos em habitat distintos daqueles relatados anteriormente, como lodo anaeróbio.

Cloacamonas também foi identificado apenas nas amostras inicias de operação dos reatores (Figura 5-22). Chouari e colaboradores (2005) avaliaram a composição do lodo anaeróbio proveniente de estação de tratamento de esgoto e constataram que por volta de $10 \%$ da composição bacteriana era composta por um novo candidato à divisão, a WWE1, grupo na qual Cloacamonas se classifica. Este grupo realiza preferencialmente a fermentação, sendo capaz de utilizar formiato e produzir $\mathrm{CO}_{2}$ e $\mathrm{H}_{2} \mathrm{e}$, por conseguinte, pode crescer com microrganismos consumidores de $\mathrm{H}_{2}$, como metanogênicos, redutores de sulfato e acetogênicos (PELLETIER et al., 2008). Assim, a identificação destes microrganismos no inóculo pode ser explicada pela sua importância ecológica em reatores metanogênicos. A ausência de identificação desses representantes nas amostras do final da operação, provavelmente, pode estar relacionada com a presença do PCB, que afetou a estrutura microbiana (LIANG et al., 2015) e ocasionou a seleção de microrganismos resistentes.

Também, foram identificadas bactérias semelhantes a Synergistes (família Synergistaceae) (JUMAS-BILAK et al., 2007; JUMAS-BILAK; ROUDIÈRE; MARCHANDIN, 2009), a qual inclui microrganismos anaeróbios com capacidade de realizar a degradação de aminoácidos (JUMAS-BILAK et al., 2007). Em sistemas anaeróbios de tratamento de águas residuárias, estas bactérias estão sempre 
presentes, possivelmente devido à presença de altas concentrações de aminoácidos no sistema (DIGNAC et al., 2000). Assim, a presença deste grupo nas amostras MT0, bem como MT2 é elucidada pela presença natural destes microrganismos no lodo, fato corroborado por outras pesquisas realizadas com o mesmo inóculo (DELFORNO et al., 2012; SILVA, 2012), e com diferentes fontes de inoculação (ROSSETTI, 2003; SOUSA et al., 2007; ITO et al., 2011; SCHERR et al., 2012), os quais identificaram representantes deste grupo nos reatores anaeróbios.

Verificou-se para representantes pertencentes a quatro grupos, Thermotogaceae, Sedimentibacter, Anaerolinaceae e Pseudomonas, baixa abundância relativa nas amostras MT0 (de 0 a $0,04 \%$ ), mas, que foram favorecidas nas amostras MT2, (de 2,5 a 29,6\%).

Os representantes da ordem Thermotogales realizam fermentação e são geralmente classificados como termofílicos e hipertermofílicos (KUEVER; RAINEY; WIDDEL, 2005), entretanto, há relatos de representantes dessa ordem em ambientes mesófilos (HOLOMAN et al., 1998; DAHLE et al., 2011; NESB $\varnothing$ et al., 2012; OKADA, 2012; SILVA, 2012). Membros da família Thermotogaceae foram identificados em sistemas marinhos, terrestre, hidrotermal, reservatórios de petróleo (RAVOT et al., 1995; L'HARIDON et al., 2001; KUEVER; RAINEY; WIDDEL, 2005; MIRANDA-TELLO et al., 2007; CHENG et al., 2013) e em reatores metanogênicos (BALK; WEIJMA; STAMS, 2002; BRIONES et al., 2009; LI et al., 2013a; BHANDARI; GUPTA, 2014). Apesar de nenhum membro desse grupo ter sido comprovadamente responsável pela desalogenação do PCB, vários representantes dessa ordem foram isolados de amostras onde a degradação do PCB foi comprovada (HOLOMAN et al., 1998; WU; SOWERS; MAY, 2000; WATTS et al., 2001; YAN; LAPARA; NOVAK, 2006; ZHAXYBAYEVA et al., 2012). Destaca-se que representantes deste grupo foram apenas identificados nas amostras MT2 e pode indicar que estes microrganismos desempenham papel importante na remoção do PCB.

Sedimentibacter é caracterizado por incluir microrganismos anaeróbios estritos que crescem sob condições de desalogenação redutiva, apesar da sua capacidade de remover halogênios não ter sido comprovada (VOS et al., 2011). Representantes desse gênero foram identificados em sedimentos intensamente contaminados por clorofenóis, $\mathrm{PCB}$ e hidrocarbonetos policíclicos aromáticos do Estuário São Vicente (São Paulo, Brasil) (SAIA et al., 2007). Representantes deste gênero realizam sintrofismo com Dehalobacter sp., espécie reconhecidamente capaz de desalogenar compostos clorados (GROSTERN; EDWARDS, 2009; GROSTERN et al., 2010; MAPHOSA et al., 2012; WANG; HE, 2013b). Esta relação sugere que fatores essenciais para Dehalobacter, são supridos por Sedimentibacter, demonstrando o importante papel deste gênero em ambientes com atividade de desalogenação (MAPHOSA et al., 2012). Assim, o aumento na abundância relativa nas amostras MT2 de Sedimentibacter, cuja remoção de congêneres de PCB foi de até $100 \%$, corrobora com trabalhos anteriores em que a degradação do PCB foi simultânea com o aumento da abundância relativa desse gênero (GOMES et al., 2014), e pode-se indicar sua importância na remoção do PCB.

O filo Cloroflexi é um grupo muito heterogêneo e com poucos representantes cultivados (YAMADA et al., 2006). Representantes do filo Chloroflexi foram identificados em abundância em lodo anaeróbio (CHOUARI et al., 2005) e representam grande parte das culturas filamentosas em sistemas anaeróbios de tratamento de águas residuárias (BJORNSSON et al., 2002), principalmente em reatores UASB (YAMADA et al., 2005). Tais representantes contribuem na degradação de carboidratos e outros componentes celulares como aminoácidos, (YAMADA et al., 2005). Dehalococcoides ethenogenes 195 foi a primeira espécie isolada e descrita (MAYMO-GATELL et al., 1997) pertencente a esse filo, capaz de realizar a desalogenação redutiva do PCB. 
Representantes da classe Anaerolineae foram identificados em diversas amostras ambientais (YAMADA et al., 2006), e há apenas duas espécies classificadas, Anaerolinea thermophila e Calidilinea aerophila, ambas encontradas em condições termofílicas (SEKIGUCHI et al., 2003). Entretanto, Cheng et al (2013) avaliaram o enriquecimento de microrganismos capazes de realizar a degradação de hidrocarbonetos alcanos sob condições metanogênicas em temperatura mesofílica. Os autores identificaram representantes da família Anaerolinaceae nas diluições seriadas. Além disso, Leigh et al. (2007b) identificaram representantes pertencentes a essa classe em amostras de solo contaminado com bifenila. Assim, apesar deste grupo ser filogeneticamente distinto de Dehaloccocoides, podem auxiliar na remoção do PCB nos reatores.

Pseudomonas é caracterizada como microrganismos com metabolismo restrito que utilizam o oxigênio como receptor final de elétrons, entretanto, com alguns representantes capazes de utilizar nitrato como receptor alternativo, permitindo seu crescimento em condições anóxicas (DAUM et al., 1998; BOONE et al., 2005). Além disso, estes microrganismos foram identificados em grânulos de reatores UASB (ATUANYA; AIGBIRIOR, 2002; KEYSER; BRITZ; WITTHUHN, 2007). Assim, a elevada abundância relativa destes microrganismos em MT2 pode ser relacionada com a natural presença destes microrganismos no inóculo.

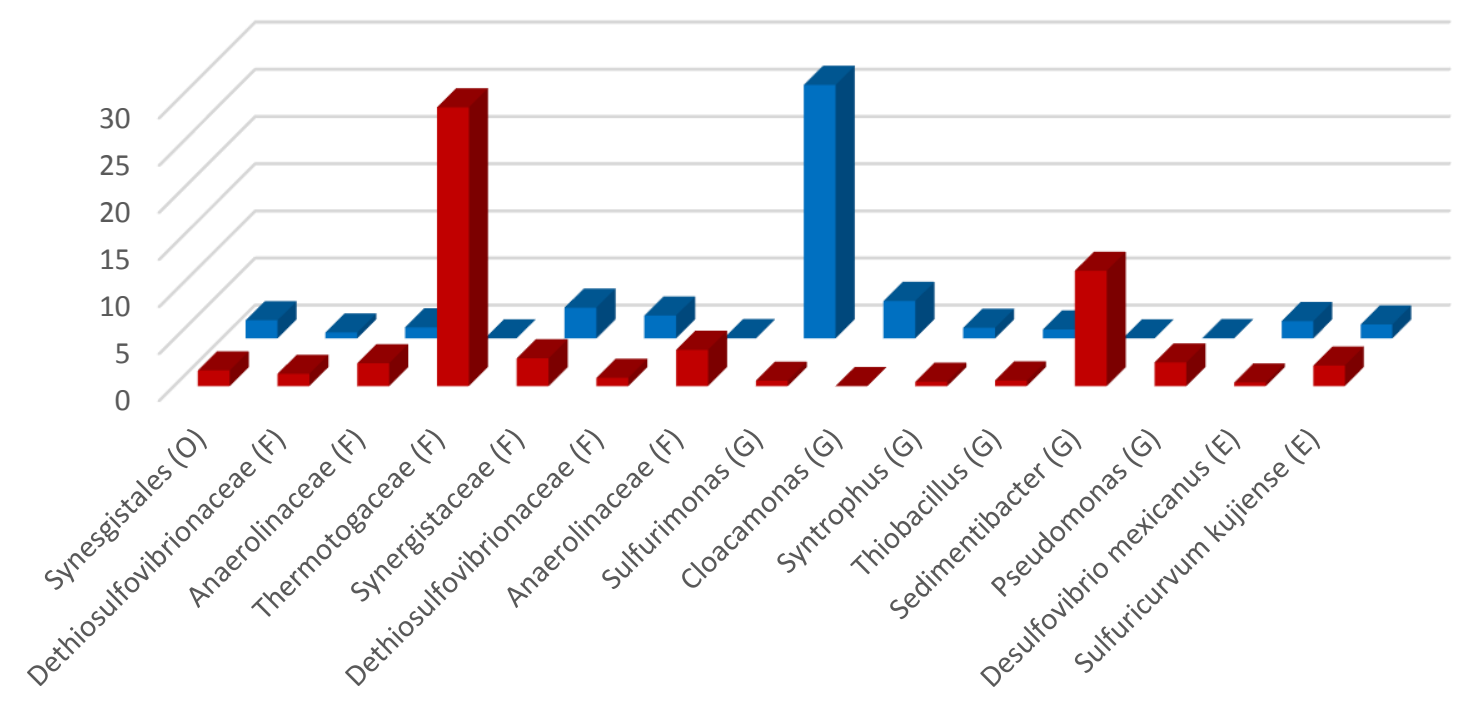

Figura 5-22 Distribuição da abundância relativa dos 10 grupos mais abundantes no início ( $₫$ MT0) e no final (-MT2) da operação dos reatores (97\% de similaridade). (O) representa a classificação em nível de Ordem, (F) representa a classificação em nível de Família, (G) representa a classificação em nível de Gênero e (E) em nível de Espécie.

Em relação aos representantes da comunidade metanogênica verificou-se visível diminuição desse grupo ao longo do tempo de operação dos reatores. Por exemplo, verificou-se para Methanosaeta, 
de 6.025 UTOs identificadas no tempo inicial (MT0) para 548 UTOs no tempo final (MT2) (Tabela 5-21). Arqueias semelhantes a Methanosaeta são estritamente metanogênicas acetoclásticas (DWORKIN et al., 2006). Nos reatores MT1 e MT2 verificou-se elevada produção de ácido acético, respectivamente de $1.077,9 \mathrm{mg} . \mathrm{L}^{-1}$ e $70,9 \mathrm{mg} . \mathrm{L}^{-1}$. Nas condições impostas do MT2, essas arqueias não foram favorecidas, em relação a condição inicial (MT1).

Calli et al. (2005), investigaram a dinâmica populacional em reatores metanogênicos com aumento gradual de amônia, e constataram que Methanosaeta era a mais abundante no início da operação, e que ao longo do tempo de operação foi sendo substituída por Methanosarcina. Os autores atribuíram esse fato a maior sensibilidade de Methanosaeta a maior concentração do composto tóxico. Assim, comparando-se os resultados encontrados no presente estudo e aqueles obtidos por Calli et al. (2005) é possível inferir que Methanosaeta é sensível a presença de PCB, e sua abundancia diminuiu ao longo do tempo de operação (de 6.025 UTOs no MT0 para 548 UTOs no MT2), para 1,5 mg.L.1 de PCB.

Representantes da família Methanoregulaceae, especificamente representantes semelhantes a Methanolinea, são caracterizados pela metanogênese hidrogenotrófica e capacidade de consumir formiato de sódio (SAKAI et al., 2012). Estes microrganismos foram identificados em grânulo de reatores UASB (YAMAMOTO et al., 2014). Assim, a elevada abundância relativa destes microrganismos, tanto em MT0, quanto em MT2 (1.245 UTOs e 801 UTOs) pode ser relacionada com a natural presença destes microrganismos no inóculo e favorecida pela presença de formiato de sódio nos reatores anaeróbios.

Membros do gênero Methanobacterium crescem preferencialmente utilizando $\mathrm{CO}_{2}$ e $\mathrm{H}_{2}$, entretanto, algumas espécies são capazes de utilizar apenas formiato (DWORKIN et al., 2006). Methanobacterium bryantii foi identificada primeiramente em digestores anaeróbio (DWORKIN et al., 2006). Assim, verificou-se para Methanobacterium bryantii e Methanobacterium elevada abundancia em MT2 (de 55 UTOs e 49 UTOs para 100 UTOs e 124 UTOs, respectivamente).

Tabela 5-21 Microrganismos do Domínio Archaea nos reatores metanogênicos no tempo inicial (T0) e final (T2) de operação (97\% de similaridade).

\begin{tabular}{|c|c|c|}
\hline Domínio Archaea & UTOs $^{1}$ & UTOs $^{2}$ \\
\hline Methanosaeta & 6.025 & 548 \\
\hline Methanoregulaceae & 1.245 & 801 \\
\hline Methanolinea & 255 & 410 \\
\hline Methanobacterium bryantii & 55 & 100 \\
\hline Methanobacterium & 49 & 124 \\
\hline TOTAL & 7.629 & 1.983 \\
\hline
\end{tabular}

\subsubsection{Exames Microscópicos}

A comunidade microbiana dos reatores metanogênico $(\mathrm{M})$ e controle metanogênico $(\mathrm{CM})$ do Ensaio de Remoção de PCB foi caracterizada morfologicamente por meio de exames microscópios de contraste de fase e de fluorescência no tempo inicial (T0) e final de operação (T2).

Na caracterização morfológica dos reatores controle no tempo inicial e final (CMT0 e CMT2) (Figura 5-23) foi possível verificar massa amorfa, provavelmente resultado de morte celular por meio 
da inativação por tratamento térmico e bactérias filamentosas. Nas amostras dos reatores no tempo final de operação (CMT2) foi observada também alguns bacilos, microrganismos que possivelmente se restabeleceram no sistema depois do tratamento térmico.

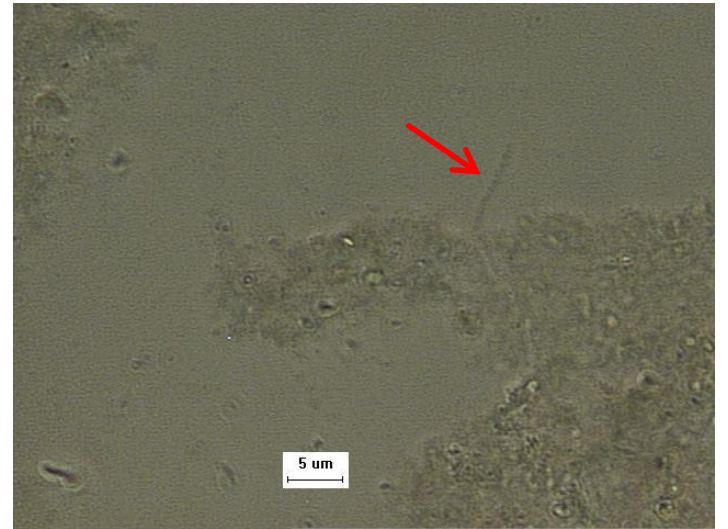

(a)

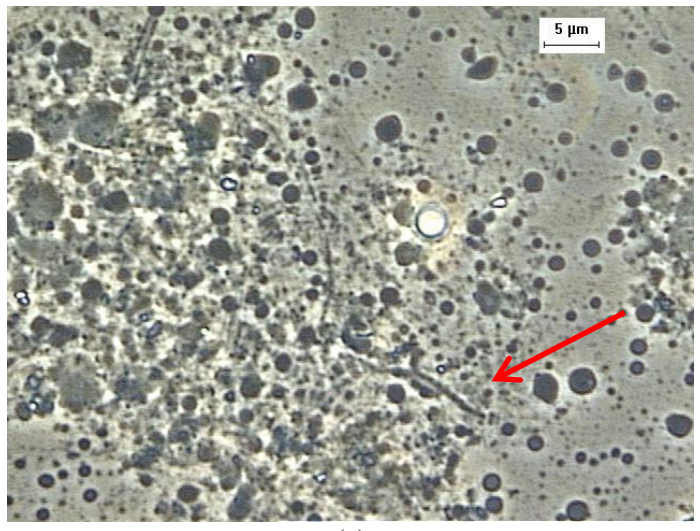

(c)

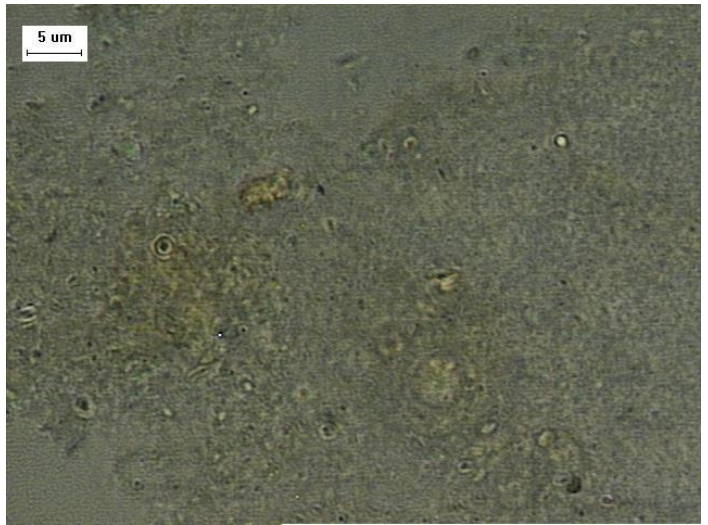

(b)

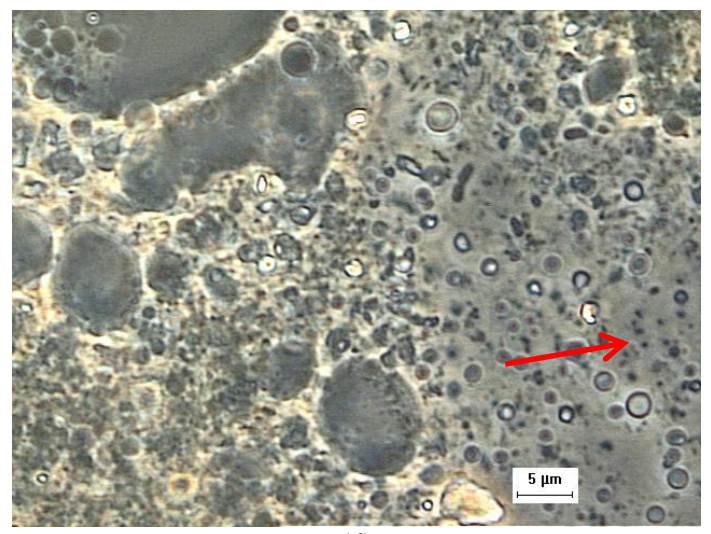

(d)

Figura 5-23. Microscopia óptica comum da biomassa inativada por meio de tratamento térmico do lodo anaeróbio nos reatores controle metanogênico (CMT0 e CMT2). (a) filamentosa no reator CMT0, (b) massa amorfa resultante da inativação da biomassa do reator CMT0, (c) filamentosa da biomassa do reator CMT2, (d) cocos na biomassa do reator CMT2 depois da inativação por meio de tratamento térmico.

$\mathrm{Na}$ caracterização morfológica dos reatores metanogênicos no tempo inicial e final (MT0 e MT2) (Figura 5-24) foi possível verificar predomínio de bacilos, filamentos septados, além de arqueias metanogênicas semelhantes a Methanosarcina e bacilos fluorescentes. Methanosarcina não foi identificada no sequenciamento massivo, mas sua presença na amostra final dos reatores não pode ser verificada por meio do sequenciamento massivo devido a limitação da amplitude do iniciador utilizado nesta técnica. 


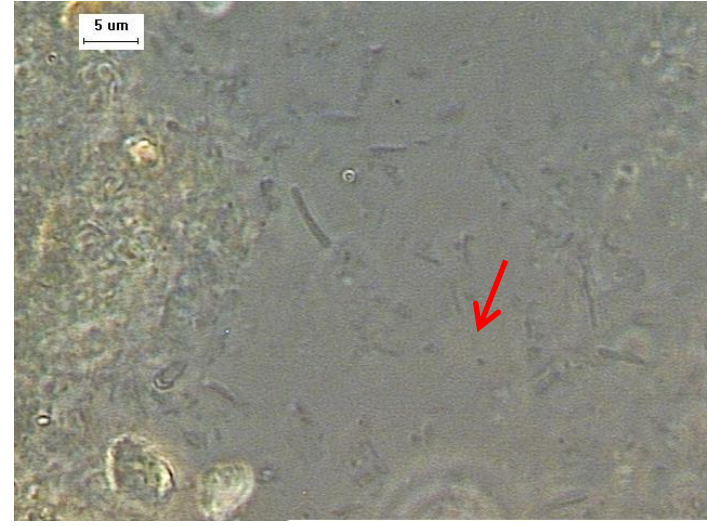

(a)

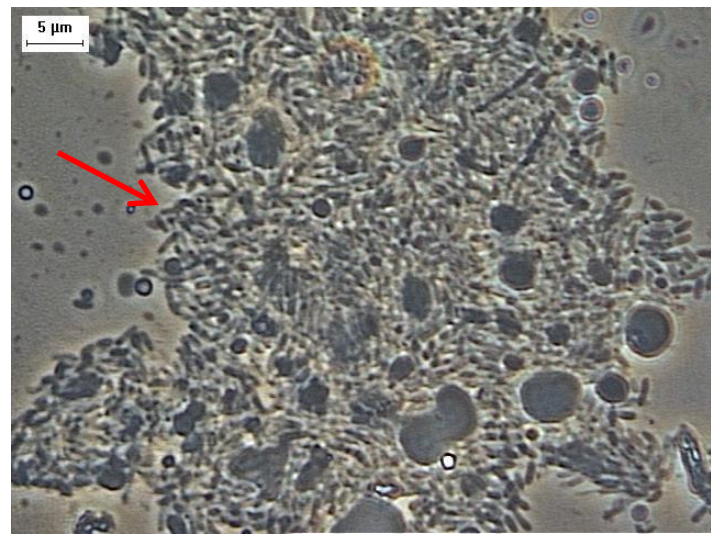

(c)

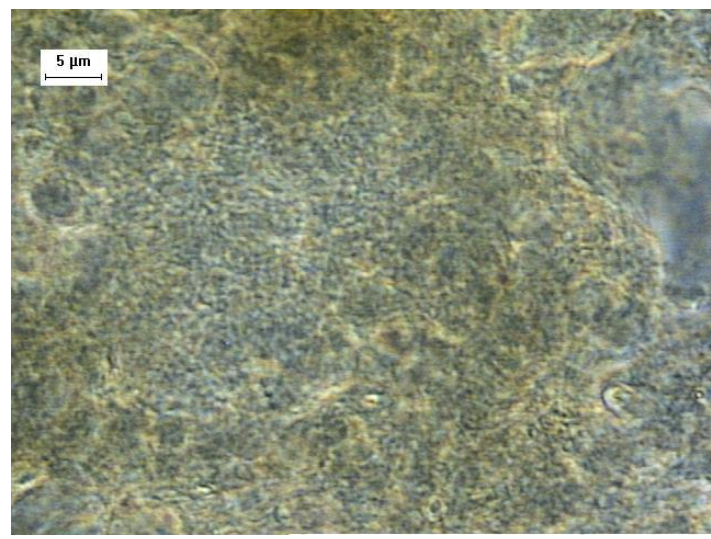

(e)

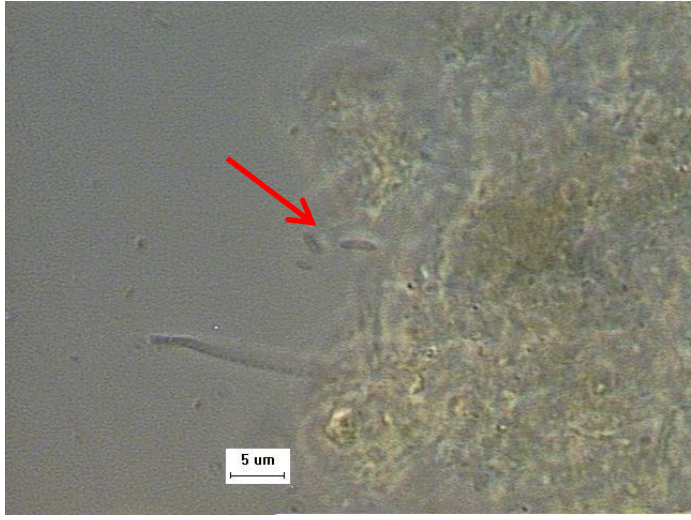

(b)

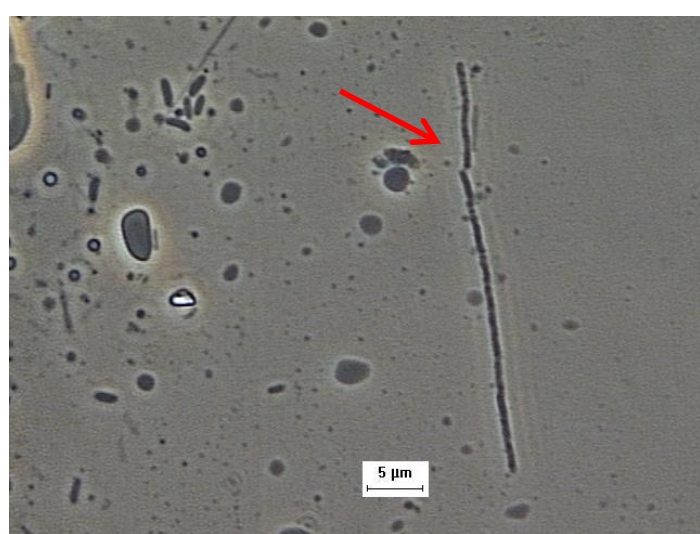

(d)

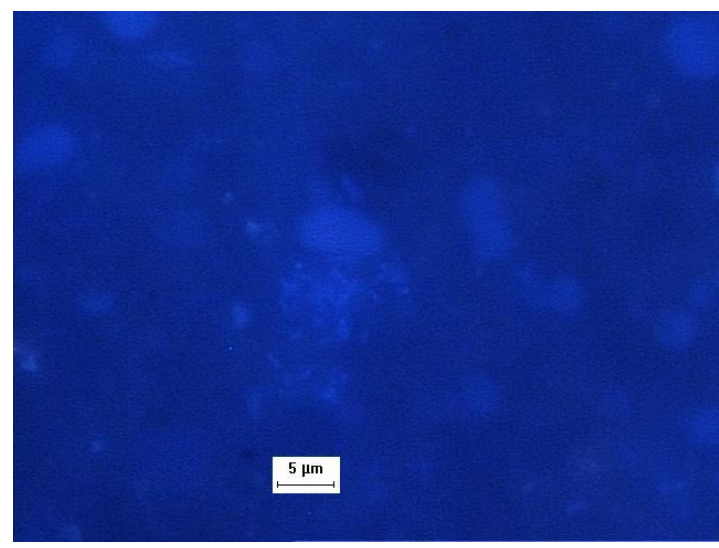

(f)

Figura 5-24. Microscopia óptica comum da biomassa do lodo anaeróbio proveniente dos reatores metanogênicos (MT0 e MT2). (a) e (b) bacilos nos reatores MT0, (c) bacilos envoltos em bolhas inertes na amostra MT0, (d) filamentosas na amostra MT2, (e) e (f) morfologia semelhantes a Methanosarcina na amostra MT2.

\subsubsection{Caracterização da comunidade microbiana}

A comunidade microbiana proveniente do Ensaio de Remoção de PCB, dentre elas amostras do reator controle (CM) e metanogênico (M) no tempo inicial (CMT0 e MT0), com 78 dias de operação (CMT1 e MT1) e no final da operação, com 101 dias (CMT2 e MT2) foram analisadas em termos de composição e diversidade microbiana. A correlação filogenética estabelecida para o Domínio Archaea 
e Bacteria esta apresentada na Figura 5-25 [a] e [b]. A diversidade bacteriana estabelecida a partir dos perfis de DGGE de cada amostra foi medida como índice de diversidade de Shannon-Wiener (H').

Mediante a análise do cluster do perfil de bandas do PCR/DGGE foram observadas mudanças nas populações microbianas, tanto, para o Domínio Bacteria, quanto para o Domínio Archaea. Observou-se maior variação dos coeficientes de similaridade para o Domínio Archaea (de 50\% a 85\%) do que para o Domínio Bacteria (de 57\% a 72\%). Ao longo da operação dos reatores metanogênico (M) e controle (CM) foi possível verificar diferentes padrões de bandas, tanto para o Domínio Archaea, quanto para Bacteria.

Por meio da comparação do perfil de bandas para o Domínio Bacteria observou-se valores de similaridade de $71 \%$ entre as amostras MT0 e MT2, de 76\% entre as amostras MT1 e CMT1 e de 57\% entre CMT0 e as outras amostras.

Ademais, por meio da comparação do perfil de bandas da biomassa para o Domínio Archaea observou-se maior similaridade entre as amostras MT1 e MT2 e entre CMT0 e CMT1, de 85\% e 76\%, respectivamente.

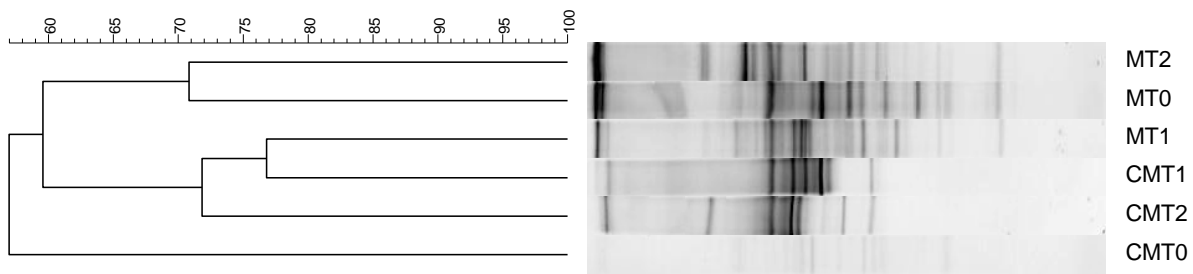

(a)
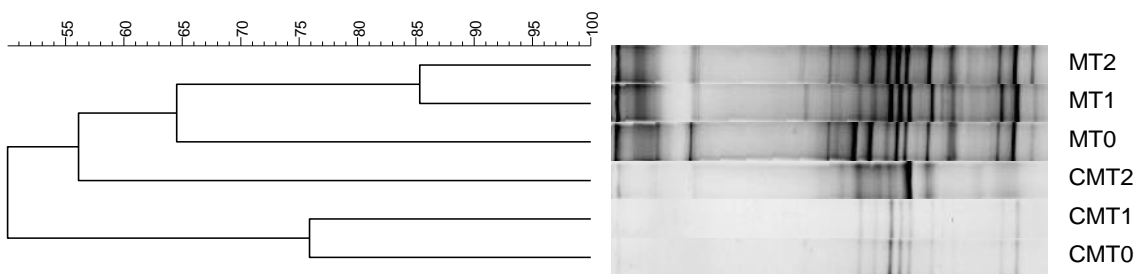

(b)

Figura 5-25 Análise de cluster (Correlação de Pearson) do perfil de bandas do PCR/DGGE para o (a) Domínio Bacteria e (b) Archaea para as amostras reatores metanogênico no início (MT0), no meio (MT1) e final da operação (MT2), bem como para os reatores controle no início (CMT0), no meio (CMT1) e final da operação (CMT2).

Verificou-se para o Domínio Archaea índice de diversidade de Shannon-Wienner (H') similar para a biomassa do reator MT0 e CMT0 (3,13 e 3,16, respectivamente) (Tabela 5-22). Ainda, para o Domínio Archaea verificou-se diminuição dos índices de diversidade ao longo do tempo de operação dos reatores metanogênicos $(\mathrm{M})$, de 3,13, 3,11 e 2,39, respectivamente para MT0, MT1 e MT2. Entretanto, para os reatores controle (CM), evidenciou-se recuperação da diversidade microbiana, por meio do índice de Shannon-Wienner (H'), de 3,16, 2,18 e 2,41, para CMT0, CMT1 e CMT2, respectivamente. 
Entretanto, para o Domínio Bacteria verificou-se menor índice de similaridade no tempo final de operação dos reatores metanogênico (M), de 2,91, 3,01 e 1,97, respectivamente para MT0, MT1 e MT2. Para os reatores controle (CM), evidenciou-se recuperação da diversidade microbiana, por meio do índice de Shannon-Wienner (H'), de 2,01, 2,17 e 3,17, para CMT0, CMT1 e CMT2, respectivamente.

A partir desses resultados pode-se inferir que a presença de PCB afetou a diversidade microbiana da biomassa anaeróbia e que houve restabelecimento da comunidade microbiana nos reatores controle.

Ademais, verificou-se neste estudo, maior índice de diversidade Shannon-Wienner (H') por meio do PCR/DGGE no tempo inicial de operação, MT0 (de 3,13 e 2,91, respectivamente para o Domínio Archaea e Bacteria) em relação ao tempo final de operação do reator, MT2 (de 2,39 e 1,97, respectivamente para o Domínio Archaea e Bacteria).

Por meio do índice de diversidade Shannon-Wienner (H') a partir do sequenciamento massivo das amostras do reator metanogênico (MT0 e MT2) observou-se valores menores (3,58 e 3,81, respectivamente para o Domínio Archaea e Bacteria) no final da operação (MT2), quando comparados com aqueles para as amostras iniciais (MT0), ou seja, de 4,24 e 4,73, respectivamente para o Domínio Archaea e Bacteria.

Comparando-se as duas análises do índice de diversidade Shannon-Wienner (H'), por meio do PCR/DGGE e sequenciamento massivo foi possível verificar menor índice de diversidade para as amostras MT2, em ambas as análises, tanto para o Domínio Archaea quanto Bacteria. Por meio desses resultados pode-se destacar que houve seleção de microrganismos resistentes ao PCB e, consequentemente, diminuição da diversidade microbiana.

Tabela 5-22 Índice de Shannon-Wienner $\left(\mathrm{H}^{\prime}\right)$ para as amostras dos reatores metanogênicos do Ensaio de Remoção de PCB

\begin{tabular}{cccc|ccc} 
& \multicolumn{3}{c|}{ Reator Metanogênico (M) } & \multicolumn{3}{c}{ Reator Controle (CM) } \\
& MT0 & MT1 & MT2 & CMT0 & CMT1 & CMT2 \\
\hline Domínio Archaea & 3,13 & 3,11 & 2,39 & 3,16 & 2,18 & 2,41 \\
\hline Domínio Bacteria & 2,91 & 3,01 & 1,97 & 2,01 & 2,17 & 3,17 \\
\hline
\end{tabular}

\subsection{Ensaio de Relação Carbono e Nitrogênio}

Baseando-se na literatura (SANTOS et al., 2004; PENG; MA; WANG, 2007; ADAV; LEE; LAI, 2010) foi utilizado etanol como única fonte de carbono para a comunidade anóxica e, com o intuito de minimizar as disparidades de operação dos reatores em batelada e garantir a equidade experimental, os reatores operados sob condição anóxica foram suplementados com etanol (598,9 mg.. $\left.\mathrm{L}^{-1}\right)$ em equivalência de DQO dos reatores anaeróbios (DQO de 984,63 $\mathrm{mg} \mathrm{O}_{2} \cdot \mathrm{L}^{-1}$ ).

A condição anóxica foi comprovada com a utilização do indicador de potencial redox, resazurina. Verificou-se coloração azul escuro nos reatores em batelada, e após a incubação de inóculo anóxico observou-se coloração rosa claro nos reatores em todos os ensaios (GUSMÃO, 2005). 
Os parâmetros que interferem diretamente na desnitrificação são os seguintes: concentração de carbono na forma de DQO, concentração de nitrato e a relação C/N do meio (BECCARI et al., 1983). Assim nos ensaios em que se avaliou a condição anóxica, por meio da desnitrificação, procedeu-se inicialmente a avaliação do efeito da adição do PCB na composição da DQO nos reatores anóxicos (Figura 5-26).

Verificou-se que o aumento da concentração de PCB gerou um aumento proporcional na DQO, e a partir da equação gerada pelo gráfico Concentração de PCB versus DQO, foi estimado a DQO nos Ensaios de Relação Carbono e Nitrogênio, Inibição Desnitrificante e Remoção de PCB. Verificou-se que para $0,1 \mathrm{mg} . \mathrm{L}^{-1}$ de PCB obteve-se DQO de 991,25 de $\mathrm{mg} \mathrm{O}_{2} \cdot \mathrm{L}^{-1}$.

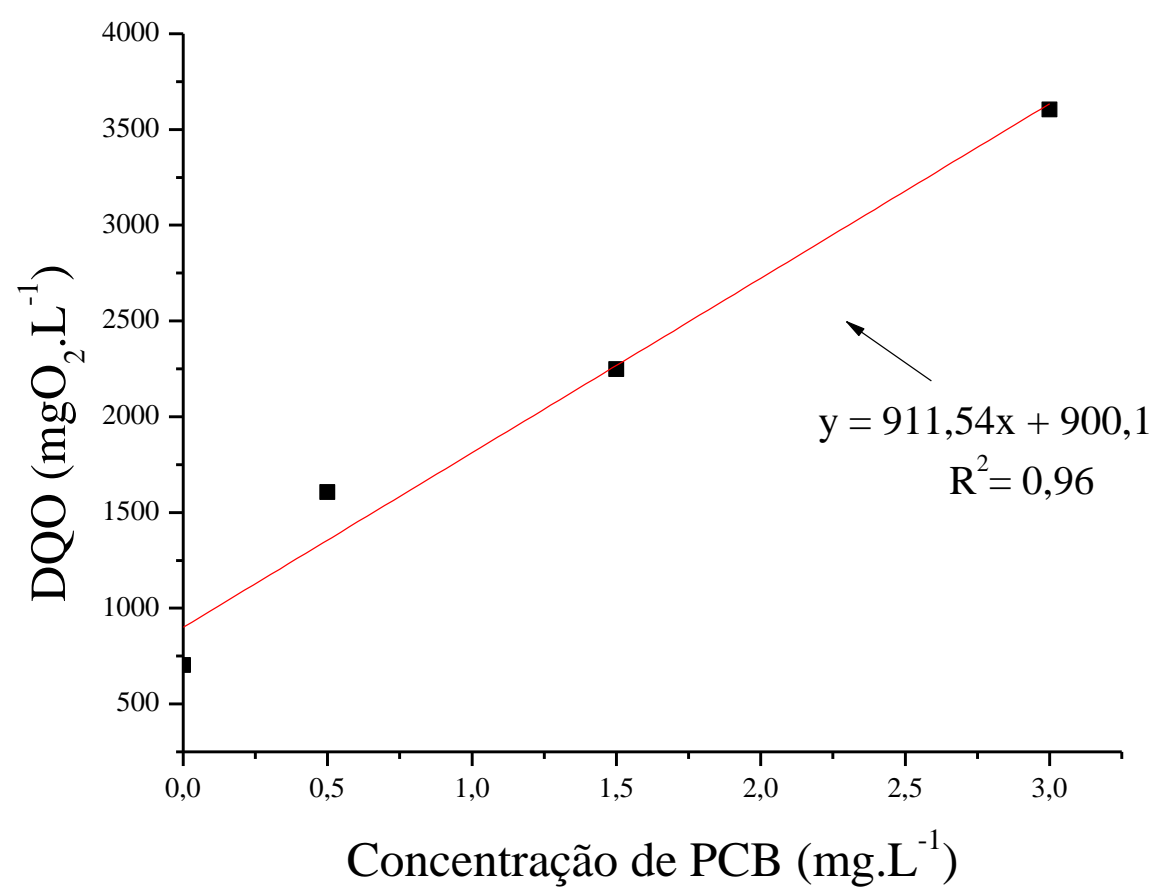

Figura 5-26 Concentração de PCB versus DQO.

A aplicação das relações 3,5:1 C/N-NO ${ }_{3}^{-}$e 1,8:1 C/N-NO ${ }_{3}^{-}$foram baseadas em trabalhos que utilizaram condição desnitrificante para a remoção de compostos aromáticos, como fenol e tolueno

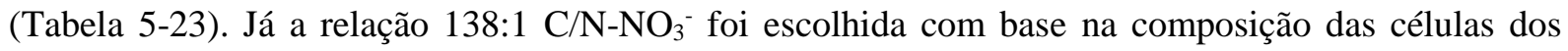
microrganismos, e se refere à concentração de nitrogênio descrita como mínima para atender as necessidades de macronutrientes dos organismos (RITTMANN; MCCARTY, 2001).

Para atingir as diferentes relações $\mathrm{C} / \mathrm{N}^{-N_{3}}{ }_{3}^{-}$fixou-se a concentração de $\mathrm{DQO}$ e variou-se a concentração de nitrato.

Tabela 5-23 Relações C/N em presença de compostos aromáticos.

\begin{tabular}{ccc} 
Referencia & Composto & Relação $\mathrm{C} / \mathrm{N}_{-} \mathrm{NO}_{3}{ }^{-}$ \\
\hline Sarfaraz et al. (2004) & Fenol & $3,4: 1$ \\
\hline Martínez-Hernández et al. (2009) & Tolueno & $1,4: 1$ \\
\hline
\end{tabular}


Neste ensaio a concentração de nitrato nas quatro relações $\mathrm{C} / \mathrm{N}^{-\mathrm{NO}_{3}}{ }^{-}(138: 1,6,6: 1,3,5: 1$ e 1,8:1) com adição de $1,5 \mathrm{mg} . \mathrm{L}^{-1}$ de PCB foram analisadas periodicamente ao longo de 16 dias de operação (408 horas) (Figura 5-27).

Observou-se que nos reatores com relação 138:1, 6,6:1 e 3,5:1 de C/N-NO ${ }_{3}^{-}$, o nitrato adicionado (93,0 mg.L ${ }^{-1}, 1.938,0$ mg.L $\mathrm{L}^{-1}$ e 3.691,0 mg.L $\mathrm{L}^{-1}$, respectivamente) foi todo consumido. Para o reator com relação 138:1, todo nitrato foi consumido em menos de 24 horas, já nos reatores com relação de 6,6:1 e 3,5:1, em 200 horas.

Ademais, foi possível verificar que para relação $1,8: 1$, com $7.150 \mathrm{mg} \cdot \mathrm{L}^{-1}$ de nitrato inicial, não ocorreu consumo total de nitrato, e $525,72 \mathrm{mg} . \mathrm{L}^{-1}$ permaneceram no sistema (nitrato residual). Resultados similares foram observados por Glass; Silverstein (1999). Os autores avaliaram três concentrações de nitrato (2.700 mg.L. $\mathrm{L}^{-1}, 5.400 \mathrm{mg} . \mathrm{L}^{-1}$ e $\left.8.200 \mathrm{mg} . \mathrm{L}^{-1}\right)$ em reatores operados em bateladas sequenciais com água residuária salina. Os autores verificaram que com aumento da concentração de nitrato ocorreu diminuição da taxa de desnitrificação, entretanto, a desnitrificação continuou ocorrendo no sistema.

Comparando-se os resultados apresentados neste trabalho e aqueles de Glass; Silverstein (1999) foi possível concluir que a elevada concentração de $\mathrm{NO}_{3}^{-}$(de $7.150 \mathrm{mg} . \mathrm{L}^{-1}$ e $8.200 \mathrm{mg} . \mathrm{L}^{-1}$, respectivamente) pode diminuir a taxa de consumo de nitrato, entretanto não inibe o metabolismo desnitrificante (KNOWLES, 1982).

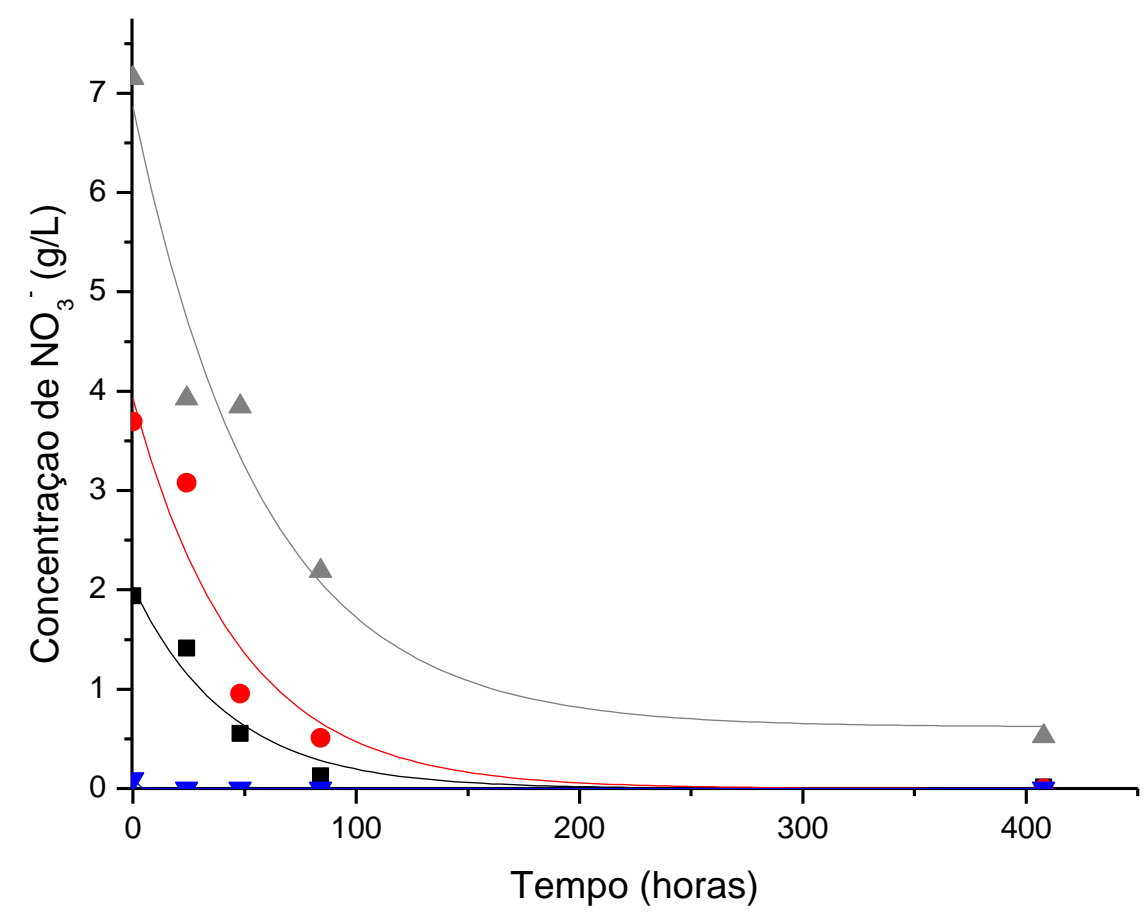

Figura 5-27 Concentração de nitrato para as relações C-DQO/N-NO ${ }^{-}$de 138:1 (- $\nabla$-), de 6,6:1 (- --), de 3,5:1 (-๑-) e de 1,8:1 (- $\triangle$-) na presença de PCB (1,5 mg. $\left.\mathrm{L}^{-1}\right)$. Símbolos representam os dados mensurados e a linha 0 ajuste a equação exponencial de decaimento. 
Os parâmetros de $\mathrm{NO}_{3}$ residual, $\mathrm{NO}_{3}$ consumido e constante de decaimento de $\mathrm{NO}_{3}$ foram obtidos com o ajuste do consumo de nitrato em relação a equação exponencial de decaimento (Tabela 5-24).

Em nenhuma das relações estudadas foi identificado o acúmulo de nitrito. O nitrito é um produto intermediário da desnitrificação e o seu acúmulo não é esperado no sistema desnitrificante (WILDERER; JONES; DAU, 1987; SUN et al., 2009) e está relacionado com insuficiente fonte de carbono suplementada no sistema (HER; HUANG, 1995). Portanto, a ausência de acúmulo de nitrito no presente trabalho confirma suficiente fonte de carbono suplementada e estabelecimento da condição desnitrificante nos reatores.

Para relação 138:1, verificou-se concentração de nitrato próxima aquela do sobrenadante proveniente do inóculo de sistema de lodos ativados $\left(88 \mathrm{mg} . \mathrm{L}^{-1}\right)$. Sob tais condições verificou-se menor constante de decaimento $\left(0,001 \mathrm{gN}-\mathrm{NO}_{3}{ }^{-} \cdot \mathrm{L}^{-1} \cdot \mathrm{h}^{-1}\right)$. A medida que foi elevada a concentração de nitrato, a

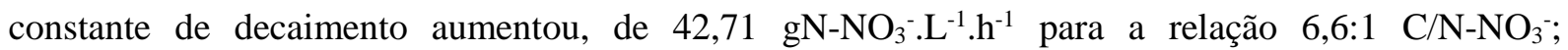
$47,19 \mathrm{gN}-\mathrm{NO}_{3}{ }^{-} \cdot \mathrm{L}^{-1} \cdot \mathrm{h}^{-1}$ para a relação de $3,5: 1 \mathrm{C} / \mathrm{N}^{-N^{2}}{ }_{3}{ }^{-}$e $57,67 \mathrm{gN}-\mathrm{NO}_{3}{ }^{-} \cdot \mathrm{L}^{-1} \cdot \mathrm{h}^{-1}$ para a relação de $1,8: 1$ $\mathrm{C} / \mathrm{N}^{-\mathrm{NO}_{3}}{ }^{-}$(Tabela 5-24). Pode-se inferir que o aumento da concentração de $\mathrm{N}^{-\mathrm{NO}_{3}}{ }^{-}$induziu maior consumo de nitrato, resultando em alta velocidade.

Verificou-se alta eficiência de desnitrificação (100\%) e ausência de $\mathrm{NO}_{3}^{-}$residual para as relações 3,5:1, 6,6:1 e 138:1 (Tabela 5-24). Para a relação 1,8:1 foi observada menor eficiência desnitrificação $(92,7 \%), \log$ o o $\mathrm{NO}_{3}$ residual neste reator foi o maior valor obtido em relação as demais condições; ou seja de 0,62 g.L $\mathrm{L}^{-1}$.

Verificou-se, ainda maior eficiência de remoção de DQO para as relações 138:1 e 6,6:1 (45,1\% e 51,9\%, respectivamente) quando comparadas com as relações 3,5:1 e 1,8:1 (17,0\% e 14,8\%, respectivamente) para $2.900 \mathrm{mg} . \mathrm{L}^{-1}$ de DQO inicial (Tabela 5-24).

Tabela 5-24 Parâmetros do Ensaio de Relação de Carbono e Nitrogênio em diferentes relações C-DQO/N-NO ${ }_{3}^{-}$.

\begin{tabular}{|c|c|c|c|c|}
\hline & $1,8: 1$ & $3,5: 1$ & $6,6: 1$ & $138: 1$ \\
\hline $\mathrm{R}^{2}$ & 0,91 & 0,90 & 0,95 & 1 \\
\hline $\mathrm{NO}_{3}$ residual $\left(\mathrm{g} . \mathrm{L}^{-1}\right)$ & $0,62 \pm 0,71$ & 0 & 0 & 0 \\
\hline $\mathrm{NO}_{3}$ consumido $\left(\mathrm{g} . \mathrm{L}^{-1}\right)$ & $6,24 \pm 0,99$ & $3,93 \pm 0,49$ & $2,03 \pm 0,18$ & $0,093 \pm 0,00008$ \\
\hline $\begin{array}{c}\text { Constante de } \\
\left.\text { deacimento (g.(L.h })^{-1}\right)\end{array}$ & $57,67 \pm 18,62$ & $47,19 \pm 13,00$ & $42,71 \pm 8,40$ & $0,001 \pm 6,0.10^{-15}$ \\
\hline $\begin{array}{c}\text { Eficiencia } \\
\text { desnitrificação } \mathrm{NO}_{\mathrm{x}}\end{array}$ & $92,7 \%$ & $100 \%$ & $100 \%$ & $100 \%$ \\
\hline $\begin{array}{c}\text { Eficiencia remoção } \\
\text { DQO } \\
(\text { DQO inicial = 2.900) }\end{array}$ & $14,8 \%$ & $17,0 \%$ & $51,9 \%$ & $45,1 \%$ \\
\hline
\end{tabular}

$\mathrm{NO}_{3}{ }^{-}$residual, $\mathrm{NO}_{3}{ }^{-}$consumido e constante de decaimento foram calculadas a partir do ajuste a equação de decaimento das concentrações de $\mathrm{NO}_{3}{ }^{-}$. Eficiência de desnitrificação foi calculada a partir dos valores de $\mathrm{NO}_{\mathrm{x}}{ }^{-}\left(\mathrm{NO}_{3}{ }^{-}\right.$e $\left.\mathrm{NO}_{2}^{-}\right)$determinada por cromatografia iônica

A partir da análise da proporção de ácidos orgânicos voláteis nos reatores (Tabela 5-25 e Figura 5-28) foi possível verificar que para relação de 138:1 e 1,8:1, o co-substrato adicionado (etanol) não foi todo consumido, com concentração final de $141,8 \mathrm{mg} . \mathrm{L}^{-1}$ e $11,1 \mathrm{mg} . \mathrm{L}^{-1}$, respectivamente. Estes resultados podem ser explicados pelo fato das bactérias desnitrificantes serem as principais consumidoras de etanol no sistema de lodos ativados (GERARDI, 2003), e tanto a baixa concentração 
de $\mathrm{NO}_{3}{ }^{-}$nos reatores em batelada para relação $138: 1\left(93 \mathrm{mg} \cdot \mathrm{L}^{-1}\right)$, quanto a alta concentração de $\mathrm{NO}_{3}{ }^{-}$ nos reatores da relação 1,8:1 (7.150 mg. $\left.\mathrm{L}^{-1}\right)$ podem ter restringido a atividade das bactérias desnitrificantes, diminuindo o consumo de etanol (GLASS; SILVERSTEIN, 1998).

Em relação aos ácidos orgânicos voláteis para as relações 138:1, 6,6:1, 3,6:1 e 1,8:1 observouse elevada concentração de ácido acético $\left(37,7 \mathrm{mg} . \mathrm{L}^{-1}, 1.333,6 \mathrm{mg} . \mathrm{L}^{-1}, 154,7 \mathrm{mg} . \mathrm{L}^{-1}\right.$ e $20,1 \mathrm{mg} . \mathrm{L}^{-1}$, respectivamente) e ácido propiônico (18,7 mg.L $\mathrm{L}^{-1}, 396,9 \mathrm{mg} . \mathrm{L}^{-1}, 36,8 \mathrm{mg} . \mathrm{L}^{-1}$ e 21,4 mg.L $\mathrm{L}^{-1}$, respectivamente).

Tabela 5-25 Concentração e porcentagem de ácidos orgânicos voláteis no meio sintético mais fonte de carbono, nos reatores no tempo inicial (T0) e final (TF) de operação para as diferentes relações de $\mathrm{C} / \mathrm{N}-\mathrm{NO}_{3}$.

\begin{tabular}{|c|c|c|c|c|c|c|c|c|c|}
\hline Amostra & Unidade & Etanol & $\begin{array}{c}\text { Ac. } \\
\text { Acético }\end{array}$ & $\begin{array}{c}\text { Ac. } \\
\text { Propiônico }\end{array}$ & $\begin{array}{c}\text { Ac. } \\
\text { Isobutírico }\end{array}$ & $\begin{array}{c}\text { Ac. } \\
\text { Butírico }\end{array}$ & $\begin{array}{c}\text { Ac. } \\
\text { Isovalérico }\end{array}$ & $\begin{array}{c}\text { Ac. } \\
\text { Valérico }\end{array}$ & $\begin{array}{c}\text { Ac. } \\
\text { Capróico }\end{array}$ \\
\hline $\begin{array}{c}\text { Co- } \\
\text { substrato } \\
\text { (etanol) }\end{array}$ & $\operatorname{mg} . \mathrm{L}^{-1}$ & 2441,35 & 0,00 & 0,00 & 0,00 & 0,00 & 0,00 & 0,00 & 0,00 \\
\hline 138:1 - T0 & $\mathrm{mg} \cdot \mathrm{L}^{-1}$ & 1707,94 & 15,88 & 17,01 & 0,00 & 17,40 & 17,27 & 15,62 & 8,86 \\
\hline 138:1 - TF & mg.L. ${ }^{-1}$ & 141,82 & 37,75 & 18,73 & 20,51 & 16,92 & 18,37 & 0,00 & 8,77 \\
\hline $6,6: 1-\mathrm{T} 0$ & $\mathrm{mg} \cdot \mathrm{L}^{-1}$ & 1971,30 & 18,37 & 0,00 & 0,00 & 17,43 & 17,83 & 15,95 & 8,83 \\
\hline $6,6: 1-\mathrm{TF}$ & $\mathrm{mg} \cdot \mathrm{L}^{-1}$ & 0,00 & 1333,56 & 396,93 & 1,11 & 0,28 & 205,91 & 6,58 & 3,76 \\
\hline $3,6: 1-$ T0 & $\mathrm{mg} \cdot \mathrm{L}^{-1}$ & 1907,00 & 299,67 & 0,00 & 0,00 & 18,68 & 0,00 & 0,00 & 0,00 \\
\hline $3,6: 1-\mathrm{TF}$ & mg.L $\mathrm{L}^{-1}$ & 0,00 & 154,67 & 35,50 & 23,24 & 20,99 & 23,34 & 15,40 & 9,07 \\
\hline 1,8:1 - T0 & $\mathrm{mg} \cdot \mathrm{L}^{-1}$ & 1724,79 & 79,11 & 36,80 & 20,50 & 18,64 & 17,76 & 0,00 & 0,00 \\
\hline $1,8: 1-\mathrm{TF}$ & mg.L $\mathrm{L}^{-1}$ & 10,98 & 20,11 & 21,45 & 0,00 & 17,83 & 18,11 & 15,47 & 8,89 \\
\hline $\begin{array}{c}\text { Co- } \\
\text { substrato } \\
\text { (etanol) }\end{array}$ & $\%$ & 100,00 & 0,00 & 0,00 & 0,00 & 0,00 & 0,00 & 0,00 & 0,00 \\
\hline 138:1 - T0 & $\%$ & 94,89 & 0,88 & 0,95 & 0,00 & 0,97 & 0,96 & 0,87 & 0,49 \\
\hline 138:1 - TF & $\%$ & 53,95 & 14,36 & 7,13 & 7,80 & 6,44 & 6,99 & 0,00 & 3,34 \\
\hline $6,6: 1-\mathrm{T} 0$ & $\%$ & 96,17 & 0,90 & 0,00 & 0,00 & 0,85 & 0,87 & 0,78 & 0,43 \\
\hline $6,6: 1-\mathrm{TF}$ & $\%$ & 0,00 & 68,45 & 20,37 & 0,06 & 0,01 & 10,57 & 0,34 & 0,19 \\
\hline 3,6:1 - T0 & $\%$ & 85,69 & 13,47 & 0,00 & 0,00 & 0,84 & 0,00 & 0,00 & 0,00 \\
\hline $3,6: 1-\mathrm{TF}$ & $\%$ & 0,00 & 54,81 & 12,58 & 8,24 & 7,44 & 8,27 & 5,46 & 3,21 \\
\hline 1,8:1 - T0 & $\%$ & 90,89 & 4,17 & 1,94 & 1,08 & 0,98 & 0,94 & 0,00 & 0,00 \\
\hline $1,8: 1-\mathrm{TF}$ & $\%$ & 9,73 & 17,82 & 19,01 & 0,00 & 15,80 & 16,05 & 13,71 & 7,88 \\
\hline
\end{tabular}




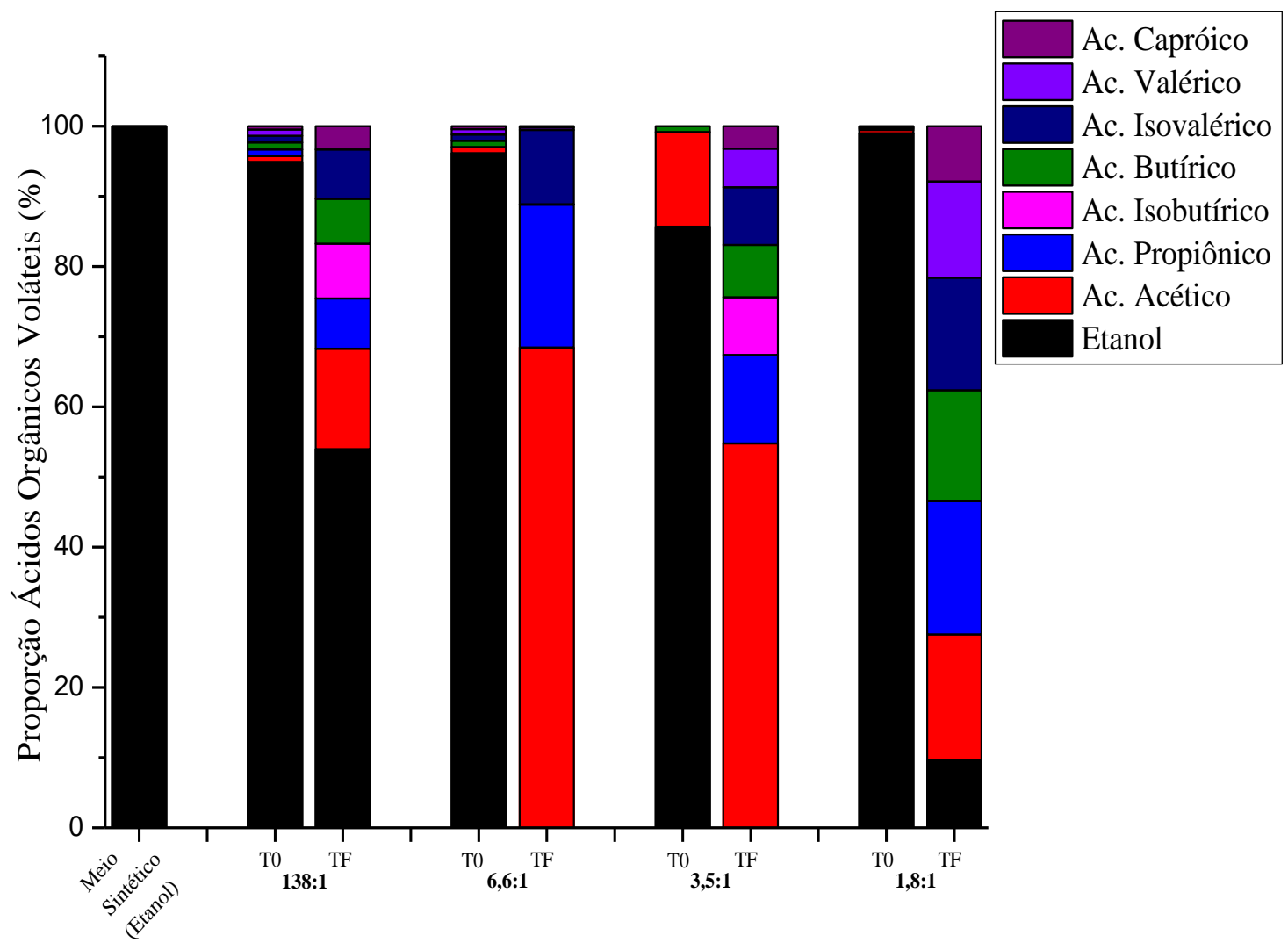

Figura 5-28 Proporção de ácidos orgânicos voláteis no meio sintético mais fonte de carbono, nos reatores no tempo inicial (T0) e final (TF) de operação para as diferentes relações de $\mathrm{C} / \mathrm{N}-\mathrm{NO}_{3}$ -

Destaca-se que para definição da relação ideal $\mathrm{C} / \mathrm{N}$ para determinado sistema deve-se obter máxima remoção de nitrato, mínimo nitrogênio residual e mínima produção de $\mathrm{N}_{2} \mathrm{O}$ (CHIU; CHUNG, 2003). Além disso, essa possibilidade pode ser calculada por meio do modelo de Bernet (BERNET; DELGENES; MOLETTA, 1996), modelo modificado de Bernet (CHIU; CHUNG, 2003), entre outros. O modelo de Bernet estipula a relação ideal de $\mathrm{C} / \mathrm{N}$ por meio da fonte de carbono mínima necessária para que ocorra a completa conversão de nitrato em $\mathrm{N}_{2}$. Já o modelo modificado de Bernet (CHIU; CHUNG, 2003) se baseia no consumo de nitrato, não mais no consumo de carbono, e pode ser utilizado para uma variada gama de fontes de carbono.

Em contrapartida, Chiu; Chung (2003) demonstraram que a utilização do método de $\mathrm{NO}_{3}$ residual para a análise da relação ideal de $\mathrm{C} / \mathrm{N}$ é válida e justificada pela sua eficiência e facilidade no cálculo. Assim, a partir deste método, a intersecção do gráfico de $\mathrm{NO}_{3}$ residual versus relação $\mathrm{C} / \mathrm{N}$ foi estabelecida como a relação ideal de $\mathrm{C} / \mathrm{N}^{-\mathrm{NO}_{3}}{ }^{-}$. No presente estudo, obteve-se relação ideal $\mathrm{C} / \mathrm{N}^{-} \mathrm{NO}_{3}{ }^{-}$ na presença de PCB (1,5 mg.L $\left.\mathrm{L}^{-1}\right)$ de aproximadamente 6,95 (Figura 5-29). 


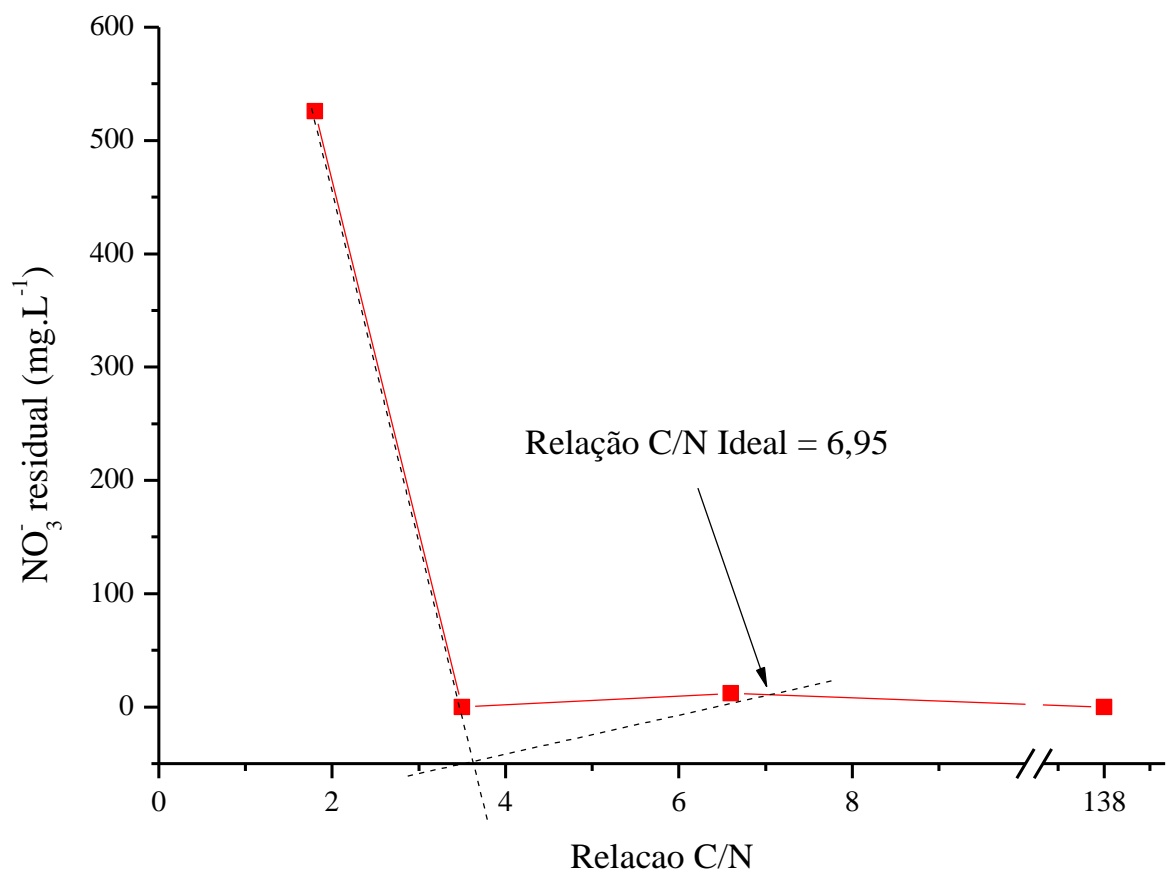

Figura 5-29 Relação $\mathrm{C} / \mathrm{N}$ ideal determinado pelo método de $\mathrm{NO}_{3}$ residual.

Ademais, como para a relação 6,6:1 verificou-se elevada eficiência de desnitrificação (100\%), sem acúmulo de nitrato residual e elevado consumo de DQO (51,9\% para $2.900 \mathrm{mg} . \mathrm{L}^{-1}$ de DQO inicial), esta relação $\mathrm{C} / \mathrm{N}^{-} \mathrm{NO}_{3}{ }^{-}(6,6: 1)$ foi escolhida para ser utilizada nos ensaios posteriores sob condição anóxica em presença de PCB.

\subsection{Ensaio Inibição Desnitrificante}

A redução completa do nitrato a gás nitrogênio envolve quatro etapas metabólicas consecutivas catalisada por diferentes enzimas. Essas enzimas são sensíveis a mudanças de pH, oxigênio dissolvido, fontes de carbono e energia e presença de inibidores, o que pode ocasionar o acúmulo de intermediários e a diminuição do consumo de nitrato (KNOWLES, 1982; FELEKE; SAKAKIBARA, 2002; KARANASIOS et al., 2010).

Neste sentido, objetivou-se no ensaio de inibição desnitrificante avaliar a concentração inibidora de PCB sobre a comunidade desnitrificante em reatores em batelada inoculados com lodo proveniente de lodos ativados, etanol como co-substrato e nitrato de sódio em 11 dias de operação (261 horas).

Por meio de ensaios preliminares, foi estipulada a relação $6,6 \mathrm{C} / \mathrm{N}^{-\mathrm{NO}_{3}}{ }^{-}$para todos os ensaios sob condição desnitrificante. Assim, neste ensaio a relação de $\mathrm{C} / \mathrm{N}-\mathrm{NO}_{3}{ }^{-}$foi mantida $(6,6)$ e para cada reator, RC (sem adição de PCB), R0,5, R1,5 e R3,0, foi adicionado diferentes concentrações de PCB, 
0,5 mg.. $\mathrm{L}^{-1}, 1,5 \mathrm{mg} . \mathrm{L}^{-1}$ e 3,0 mg.L. $\mathrm{L}^{-1}$, respectivamente, e diferentes concentrações de nitrato, 665,8 mg.L${ }^{1}, 1.113,3$ mg.L. $\mathrm{L}^{-1}, 1.544,7 \mathrm{mg} . \mathrm{L}^{-1}$ e $2.434,9 \mathrm{mg} . \mathrm{L}^{-1}$, respectivamente.

Para o reator branco $(\mathrm{RB})$ não verificou-se consumo de nitrato e para os reatores $\mathrm{RC}, \mathrm{R} 0,5, \mathrm{R} 1,5$ e R3,0 verificou-se consumo de nitrato de 665,8 mg.L $\mathrm{L}^{-1}$, 1.039,8 mg.L $\mathrm{L}^{-1}, 382,8 \mathrm{mg} . \mathrm{L}^{-1}$ e $438,8 \mathrm{mg} . \mathrm{L}^{-1}$, respectivamente, resultando em eficiência de desnitrificação de 100,0\%, 93,4\%, 24,8\% e 18,0\%, respectivamente (Tabela 5-26). A partir desses resultados foi possível verificar que com o aumento da concentração de PCB, houve diminuição na eficiência de desnitrificação e consequentemente, aumento da inibição desnitrificante, de 6,6\%, 75,2\% e 82,0\% para os reatores R0,5, R1,5 e R3,0, respectivamente (Tabela 5-26).

Como mostrado anteriormente no Ensaio de Relação Carbono e Nitrogênio, mesmo para elevada concentração de nitrato $\left(3.691,0 \mathrm{mg} . \mathrm{L}^{-1}\right)$ a eficiência de desnitrificação foi de $100 \%$. A partir desses resultados pode-se inferir que as altas concentrações de nitrato nos reatores R0,5, R1,5 e R3,0 (1.113,3 mg.L $L^{-1}, 1.544,7$ mg.L $L^{-1}$ e $2.434,9$ mg.L $L^{-1}$, respectivamente) não foram responsáveis pela taxa de inibição desnitrificante nestes reatores $(6,6 \%, 75,2 \%$ e $82,0 \%$ para os reatores R0,5, R1,5 e R3,0, respectivamente). Assim, a inibição desnitrificante encontrada nesse ensaio deveu-se provavelmente apenas a presença de PCB nos reatores.

Tabela 5-26 $\mathrm{NO}_{3}{ }^{-}$residual, consumo de $\mathrm{NO}_{3}{ }^{-}$e Eficiência de Desnitrificação $\left(\mathrm{E}_{\mathrm{D}}\right)$ nos reatores inoculados com diferentes concentrações de PCB.

\begin{tabular}{ccccc} 
& $\mathrm{RC}$ & $\mathrm{R} 0,5$ & $\mathrm{R} 1,5$ & $\mathrm{R} 3,0$ \\
\hline $\mathrm{NO}_{3}{ }^{-}$residual (mg..-1) & 0 & 73,50 & 1161,91 & 1996,18 \\
\hline $\begin{array}{c}\text { Consumo de } \mathrm{NO}_{3}{ }^{-} \\
\left(\mathrm{mg} . \mathrm{L}^{-1}\right)\end{array}$ & 665,78 & 1039,78 & 382,84 & 438,76 \\
\hline $\begin{array}{c}\text { Eficiência de } \\
\text { Desnitrificação - } \\
(\%)\end{array}$ & 100,0 & 93,4 & 24,8 & 18,0 \\
\hline $\begin{array}{c}\text { Inibição } \\
\text { Desnitrificante - \% } \\
(\%)\end{array}$ & - & 6,6 & 75,2 & 82,0 \\
\hline
\end{tabular}

Neste estudo verificou-se direta relação entre a concentração de PCB e a inibição desnitrificante (Figura 5-30). $\mathrm{O}$ valor de $\mathrm{IC}_{50}$ dos seis congêneres estudado, foi calculado a partir da curva de Doseresposta, ajustada ao gráfico de \% $\mathrm{I}_{\mathrm{D}}$ versus a concentração de $\mathrm{PCB}$, sendo obtido 1,00 mg.. $\mathrm{L}^{-1}$. Desse modo, pode-se inferir que $50 \%$ da eficiência de desnitrificação foi afetada quando $1,00 \mathrm{mg} . \mathrm{L}^{-1}$ desses seis congêneres de PCB foram adicionados nos reatores. 


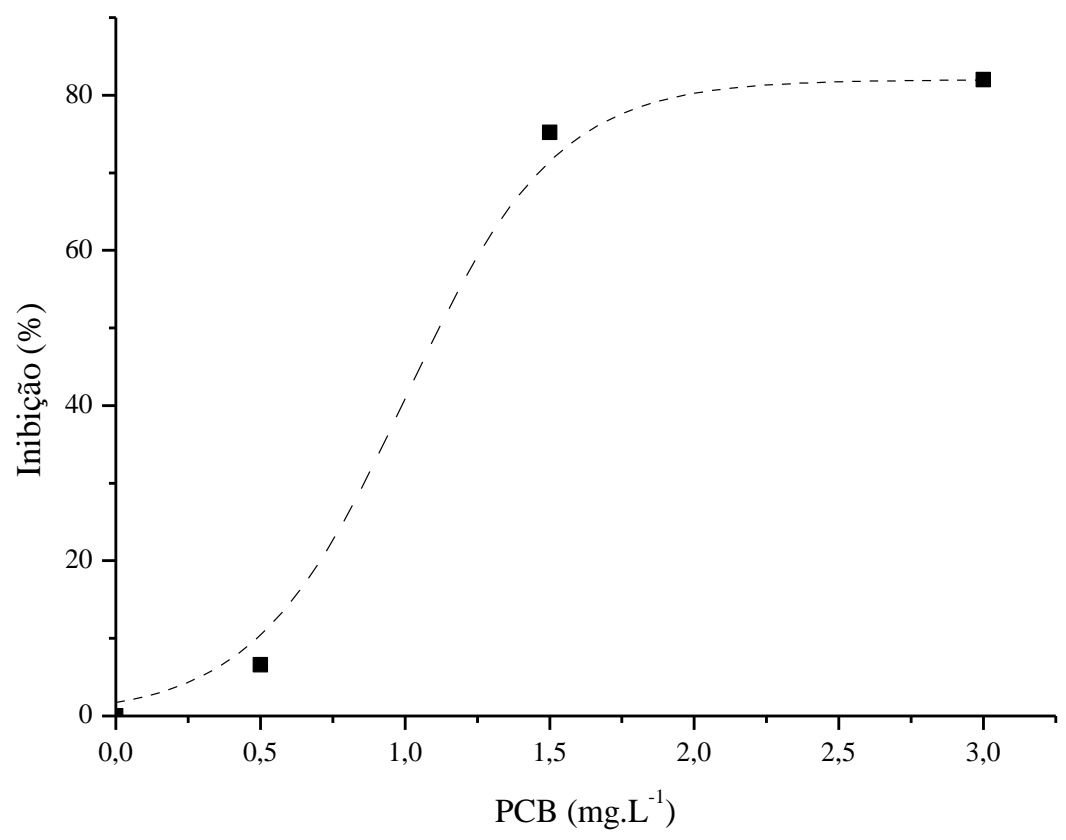

Figura 5-30 Relação entre porcentagem de inibição versus a concentração de PCB. Símbolo representa os dados e linha o ajuste à equação.

Verificou-se diminuição efetiva da remoção de matéria orgânica com o aumento da concentração de PCB (Tabela 5-27). Eficiência de remoção de 89\%, 72\%, 56\% e 17\% foi evidenciada para os reatores RC, R0,5, R1,5 e R3,0, respectivamente. A partir desses resultados pode-se concluir que a presença de PCB nos reatores afetou, tanto o consumo de nitrato, quanto o consumo de matéria orgânica.

Tabela 5-27 Ácidos orgânicos voláteis, DQO inicial e final e eficiência de remoção de DQO no Ensaio de Inibição Desnitrificante.

\begin{tabular}{|c|c|c|c|c|}
\hline Reator & $\begin{array}{c}\text { Ácidos Orgânicos } \\
\text { Voláteis } \\
\left(\mathrm{mg} \cdot \mathrm{L}^{-1}\right)\end{array}$ & $\begin{array}{l}\text { DQO inicial } \\
\left(\mathrm{mg} \cdot \mathrm{L}^{-1}\right)\end{array}$ & $\begin{array}{l}\text { DQO final } \\
\left(\mathrm{mg} \cdot \mathrm{L}^{-1}\right)\end{array}$ & $\begin{array}{c}\text { Eficiência de remoção } \\
\text { de DQO }(\%)\end{array}$ \\
\hline $\mathrm{RC}$ & 134,16 & $\begin{array}{c}936,5 \\
( \pm 8,70)\end{array}$ & $\begin{array}{c}105,76 \\
( \pm 23,59)\end{array}$ & 89 \\
\hline $\mathrm{R} 0,5$ & 178,66 & $\begin{array}{l}1.601,25 \\
( \pm 38,40)\end{array}$ & $\begin{array}{c}448,08 \\
( \pm 25,00)\end{array}$ & 72 \\
\hline $\mathrm{R} 1,5$ & 240,94 & $\begin{array}{l}2.268,25 \\
( \pm 45,70)\end{array}$ & $\begin{array}{c}981,75 \\
( \pm 99,03)\end{array}$ & 56 \\
\hline $\mathrm{R} 3,0$ & 755,31 & $\begin{array}{c}3.603,00 \\
( \pm 251,00)\end{array}$ & $\begin{array}{c}2974,97 \\
( \pm 135,53)\end{array}$ & 17 \\
\hline
\end{tabular}

Constatou-se neste trabalho que conforme aumentava-se a concentração de PCB nos reatores, intensificava-se também o acúmulo de ácidos orgânicos no sistema. Para o reator R0,5, verificou-se no final da operação 178,66 mg. $\mathrm{L}^{-1}$ de ácidos orgânicos totais, sendo $19 \%$ de ácido propiônico. Para os reatores R1,5 e R3,0, verificou-se respectivamente, 240,94 mg.L $\mathrm{L}^{-1}$ e 755,31 mg.L $\mathrm{L}^{-1}$ de ácidos orgânicos totais, sendo 53\% e 82\% de ácido acético, respectivamente (Tabela 5-28 e Figura 5-31). 
Tabela 5-28 Concentração e porcentagem de cada ácido orgânico volátil nos reatores RC (reator controle), R0,5 (reator com 0,5 mg.L ${ }^{-1}$ de PCB), R1,5 (reator com 1,5 mg.L $\mathrm{L}^{-1}$ de PCB) e R3,0 (reator com 3,0 mg.L . $^{-1}$ de PCB).

\begin{tabular}{cccccccc||c} 
Amostra & Unidade & $\begin{array}{c}\text { Ac. } \\
\text { Acético }\end{array}$ & $\begin{array}{c}\text { Ac. } \\
\text { Propiônico }\end{array}$ & Ac. Butírico & $\begin{array}{c}\text { Ac. } \\
\text { Isovalérico }\end{array}$ & $\begin{array}{c}\text { Ac. } \\
\text { Valérico }\end{array}$ & $\begin{array}{c}\text { Ac. } \\
\text { Capróico }\end{array}$ & TOTAL \\
RC & mg.L-1 & 0,00 & 0,00 & 34,29 & 38,78 & 31,88 & 22,19 & 134,16 \\
R0,5 & mg.L ${ }^{-1}$ & 27,70 & 34,65 & 33,66 & 34,67 & 30,28 & 17,71 & 178,67 \\
R1,5 & mg.L ${ }^{-1}$ & 128,30 & 0,00 & 0,00 & 42,41 & 52,42 & 17,81 & 240,94 \\
R3,0 & mg.L-1 & 621,12 & 0,00 & 0,00 & 38,80 & 76,43 & 18,97 & 755,31 \\
\hline RC & $\%$ & 0,00 & 0,00 & 25,56 & 28,91 & 23,76 & 16,54 & 100,00 \\
R0,5 & $\%$ & 15,50 & 19,40 & 18,84 & 19,40 & 16,95 & 9,91 & 100,00 \\
R1,5 & $\%$ & 53,25 & 0,00 & 0,00 & 17,60 & 21,76 & 7,39 & 100,00 \\
R3,0 & $\%$ & 82,23 & 0,00 & 0,00 & 5,14 & 10,12 & 2,51 & 100,00
\end{tabular}

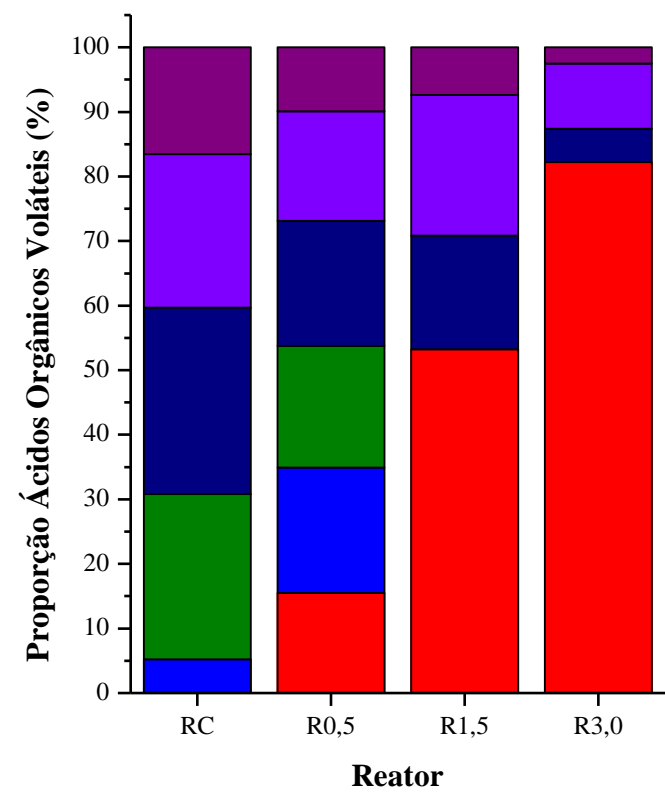

Ácido Capróico Ácido Valérico Ácido Isovalérico Ácido Butírico Ácido Propiônico Ácido Acético

Figura 5-31 Proporção de cada ácido orgânico volátil nos reatores RC (reator controle), R0,5 (reator com 0,5 mg.L $\mathrm{L}^{-1}$ de PCB), R1,5 (reator com 1,5 mg.L $\mathrm{L}^{-1}$ de PCB) e R3,0 (reator com 3,0 mg.L ${ }^{-1}$ de PCB).

Gusmão et al. (2006) verificaram na remoção de BTEX sob condição desnitrificante e etanol como co-substrato menor eficiência de remoção de DQO, quando os reatores eram alimentados com $m$ xileno, etilbenzeno e BTEX em reator anóxico horizontal de leito fixo (RAHLF). Estes autores justificaram a diminuição na eficiência pelo acúmulo de ácido acético após a sobrecarga orgânica, o que afetou a eficiência do sistema. 
No presente estudo, a partir do aumento da concentração de PCB foi observado também acúmulo de ácidos orgânicos (Tabela 5-27), principalmente ácido acético (Figura 5-31). Assim, a inibição desnitrificante pode ter sido causada diretamente pela toxicidade do PCB, bem como, pela toxicidade indireta com o acúmulo de compostos secundários do metabolismo, como o ácido acético.

A comunidade microbiana do inóculo (i), do reator controle (RC), R0.5 (0,5 mg. $\mathrm{L}^{-1}$ de PCB), R1.5 (1,5 mg.L ${ }^{-1}$ de PCB) e R3.0 (3,0 mg.L ${ }^{-1}$ de PCB) para o Domínio Bacteria foram analisados em termos de composição da comunidade microbiana. A correlação filogenética estabelecida e suas respectivas similaridades são apresentadas na Figura 5-32. A diversidade bacteriana estabelecida a partir dos perfis de DGGE de cada amostra foi medida como índice de diversidade de Shannon-Wiener (H').

Mediante análise de cluster do perfil de bandas do DGGE verificou-se que as populações dos reatores afiliaram-se influenciadas pela concentração do PCB. Observou-se índice de similaridade de 93\% para as populações dos reatores com menor concentração de PCB (R0,5 e R1,5).

Foi possível constatar também alteração na composição microbiana após inoculação nos reatores, e verificou-se $62 \%$ de similaridade entre as populações do inóculo (i) e aquelas dos reatores com PCB (RC, R0,5, R1,5 e R3,0).

Verificou-se para cada série experimental padrão de bandas exclusivo. Para as condições dos reatores com PCB (R0,5, R1,5 e R3,0) foi possível verificar padrão de bandas dominantes. Provavelmente, para cada concentração de PCB predominou uma população específica. Todavia, para a biomassa das condições sem PCB (inóculo e RC) não foi observado nenhum padrão de bandas dominante. Provavelmente, a dominância de determinada população de bactérias tenha sido diretamente relacionada com a concentração de PCB.

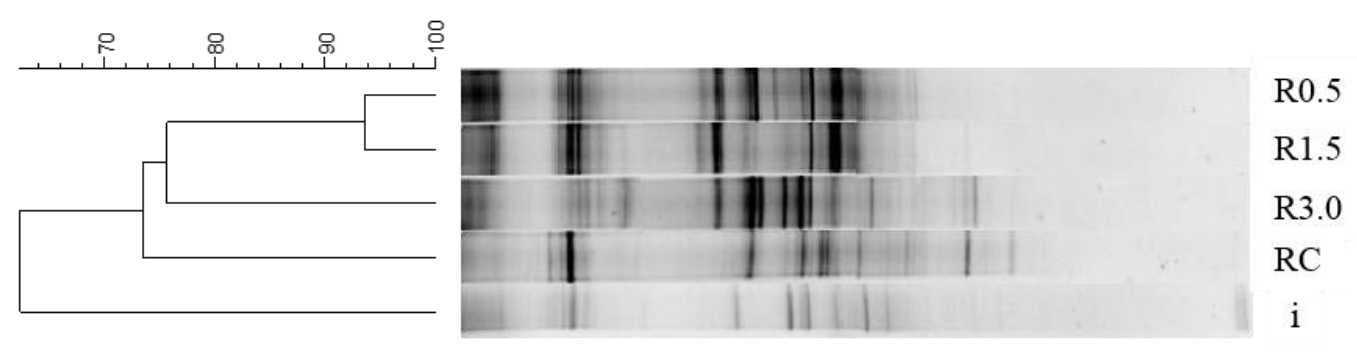

Figura 5-32 Perfis de DGGE de comunidades microbianas em RC (reator controle), i (inóculo), R0.5 (0,5 mg.L ${ }^{-1}$ de PCB), R1.5 (1,5 mg.L $\mathrm{L}^{-1}$ de PCB) e R3.0 (3,0 mg.L . $^{-1}$ de PCB) para o Domínio Bacteria. Dendrogama construído utilizando correlação de Pearson e o método de agrupamento UPGMA.

Verificou-se maior índice de diversidade de Shannon-Wienner ( $\left.\mathrm{H}^{\prime}\right)$ para as condições do Ensaio de Inibição Desnitrificante (Tabela 5-29) para a biomassa do inóculo e RC, cujos valores obtidos foram de 3,55 e 3,25, respectivamente. Para as condições do reator R3,0 verificou-se o menor índice de diversidade (2,04). Provavelmente, as populações de bactérias foram suscetíveis ao PCB e este composto causou efeito negativo no sistema desnitrificante, que sob a concentração de $3,0 \mathrm{mg} \cdot \mathrm{L}^{-1}$ de PCB, o metabolismo desnitrificante foi comprometido (inibição desnitrificante de $82,0 \%$ ) e a remoção de matéria orgânica foi a menor (17\% de eficiência de remoção de DQO). 
Tabela 5-29 Índice de diversidade de Shannon-Wienner (H') para as biomassas dos reatores e inóculo.

\begin{tabular}{|c|c|c|c|c|c|}
\hline & $\mathrm{i}$ & $\mathrm{RC}$ & $\mathrm{R} 0.5$ & $\mathrm{R} 1.5$ & R3.0 \\
\hline Domínio Bacteria & 3,55 & 3,25 & 2,77 & 3,15 & 2,04 \\
\hline
\end{tabular}

\subsection{Ensaio de Remoção PCB sob condição desnitrificante}

\subsubsection{Parâmetros de Monitoramento}

No Ensaio de Remoção de PCB foi avaliado o consumo de PCB sob condição anóxica. Para tanto, reatores em batelada foram inoculados com biomassa proveniente de lodos ativados, etanol como co-substrato $\left(598,9 \mathrm{mg} . \mathrm{L}^{-1}\right)$, nitrato $\left(1.652,2 \mathrm{mg} . \mathrm{L}^{-1}\right)$ e PCB $\left(1,5 \mathrm{mg} . \mathrm{L}^{-1}\right)$ e relação C/N-NO ${ }_{3}^{-}$de 6 por 99 dias. Os reatores desnitrificante (D) foram inoculados com biomassa ativa e os reatores controle (CD) foram inoculados com biomassa desnitrificante inativa. Ao longo do tempo de operação dos reatores foi avaliada a eficiência de desnitrificação $\left(\mathrm{E}_{\mathrm{D}}\right)$, o consumo de nitrato e DQO e a produção de ácidos orgânicos voláteis.

Nos reatores CD, inoculados com biomassa desnitrificante inativada por tratamento térmico, verificou-se consumo de matéria orgânica, sem consumo de nitrato (Tabela 5-30). van de Graaf et al. (1995) demonstraram que a comunidade desnitrificante é sensível ao aumento de temperatura e são inativadas com tratamento térmico. Por meio dos resultados observados no presente estudo pode-se inferir que as populações desnitrificantes do inóculo foram efetivamente inativadas pelo tratamento térmico, entretanto outras populações resistiram à inativação e consumiram matéria orgânica no sistema, cuja eficiência de remoção foi de $76 \%$, para 2.237,04 mg.L $\mathrm{L}^{-1}$ inicial.

A eficiência de remoção de matéria orgânica e eficiência de desnitrificação observadas nos reatores D em 99 dias foram de $94 \%$ e 100\%, respectivamente, para 2.596,06 mg. $\mathrm{L}^{-1}$ de DQO inicial e 1.652,2 mg.L $\mathrm{L}^{-1}$ de nitrato inicial (Tabela 5-30).

No Ensaio de Inibição Desnitrificante verificou-se, para o reator R1,5, com etanol (598,9 mg.L' $\left.{ }^{1}\right)$, nitrato $\left(1.544,7 \mathrm{mg} . \mathrm{L}^{-1}\right)$ e PCB $\left(1,5 \mathrm{mg} \cdot \mathrm{L}^{-1}\right)$, eficiência de remoção de DQO de $56 \%$ para $2.268 \mathrm{mg} . \mathrm{L}^{-}$

${ }^{1}$ de DQO inicial e eficiência de Desnitrificação $\left(E_{D}\right)$ de $24 \%$ em 11 dias.

Comparando-se os resultados apresentados neste ensaio (remoção de matéria orgânica e eficiência de desnitrificação de $94 \%$ e 100\%, respectivamente, em 99 dias) e no Ensaio Inibição Desnitrificante (eficiência de remoção de DQO de 56\% e eficiência de Desnitrificação de $24 \%$ em 11 dias) foi possível concluir que a eficiência de remoção de nitrato e DQO foram maiores no presente ensaio. Possivelmente, devido ao maior tempo de operação dos reatores neste ensaio ( 99 dias de operação) quando comparados com o Ensaio Inibição Desnitrificante (11 dias de operação).

Constatou-se ainda neste trabalho diferentes concentrações e distribuição de ácidos orgânicos voláteis em cada reator ao longo do tempo (Tabela 5-30). Verificou-se concentração de ácidos orgânicos voláteis decrescente com o tempo de operação dos reatores desnitrificantes, DT0, DT1 e DT2, bem como nos reatores controle desnitrificante, CDT0, CDT1 e CDT2, respectivamente de 2.524,50 mg. $\mathrm{L}^{-1}$, 520,75 mg.L ${ }^{-1}, 405,28 \mathrm{mg} . \mathrm{L}^{-1}, 2.452,06 \mathrm{mg} . \mathrm{L}^{-1}, 237,81 \mathrm{mg} . \mathrm{L}^{-1} \mathrm{e}$ 234,79 mg.L. $\mathrm{L}^{-1}$. 
Tabela 5-30 Ácidos orgânicos voláteis, DQO, eficiência de remoção de DQO e eficiência de Desnitrificação (ED) em cada reator no Ensaio de Remoção de PCB.

\begin{tabular}{|c|c|c|c|c|c|}
\hline Reator & Nitrato (mg. $\left.\mathrm{L}^{-1}\right)$ & $\begin{array}{c}\text { Eficiencia } \\
\text { Desnitrificação - } \\
\mathrm{E}_{\mathrm{D}} \\
(\%)\end{array}$ & $\begin{array}{l}\text { Ácidos Orgânicos } \\
\text { Voláteis } \\
\left(\mathrm{mg} \cdot \mathrm{L}^{-1}\right)\end{array}$ & $\begin{array}{c}\text { DQO } \\
\left(\mathrm{mg} \cdot \mathrm{L}^{-1}\right)\end{array}$ & $\begin{array}{c}\text { Eficiência de remoção de } \\
\text { DQO } \\
(\%)\end{array}$ \\
\hline DT0 & $1.652,2$ & \multirow{3}{*}{100,0} & $2.524,50$ & $\begin{array}{l}2.596,06 \\
( \pm 143,86)\end{array}$ & \multirow{3}{*}{94,69} \\
\hline DT1 & 0 & & 520,75 & $\begin{array}{l}1.036,67 \\
( \pm 60,84)\end{array}$ & \\
\hline DT2 & 0 & & 405,28 & $\begin{array}{r}137,80 \\
( \pm 15,00)\end{array}$ & \\
\hline CDT0 & $1.565,6$ & \multirow{3}{*}{0} & $2.452,06$ & $\begin{array}{c}2.237,04 \\
( \pm 43,33)\end{array}$ & \multirow{3}{*}{76,06} \\
\hline CDT1 & $1.569,1$ & & 237,81 & $\begin{array}{l}1.130,30 \\
( \pm 101,00)\end{array}$ & \\
\hline CDT2 & $1.580,8$ & & 234,79 & $\begin{array}{r}535,70 \\
( \pm 14,50)\end{array}$ & \\
\hline & $\begin{array}{r}\text { DT0 } \\
\text { DT1 }=\text { re } \\
\text { DT2 }=\mathrm{r} \\
\text { CDT0 = r } \\
\text { CDT1 }=\text { reato } \\
\text { CDT2 = reat }\end{array}$ & $\begin{array}{l}\text { ator desnitrifican } \\
\text { desnitrificante in } \\
\text { desnitrificante in } \\
\text { controle desnitri } \\
\text { trole desnitrificar } \\
\text { ntrole desnitrifica }\end{array}$ & $\begin{array}{l}\text { oculado com } 1,5 \mathrm{~m} \\
\text { ado com } 1,5 \mathrm{mg} \cdot \mathrm{L} \\
\text { lado com } 1,5 \mathrm{mg} . \mathrm{L} \\
\text { nte inoculado com } \\
\text { noculado com } 1,5 \mathrm{~m} \\
\text { inoculado com } 1,5\end{array}$ & $\begin{array}{l}\text { de PCB n } \\
\text { PCB com } 7 \\
\text { PCB no te } \\
\text { hg. } \mathrm{L}^{-1} \text { de P } \\
{ }^{1} \text { de PCB } \\
{ }^{-1} \text { de PCB }\end{array}$ & $\begin{array}{l}\text { cial, } \\
\text { peração, } \\
99 \text { dias), } \\
\text { po inicial, } \\
\text { de operação, } \\
\text { inal (99 dias) }\end{array}$ \\
\hline
\end{tabular}

Tanto, nos reatores desnitrificantes (D), quanto nos reatores controle (CD) verificou-se consumo do etanol (Tabela 5-31). É conhecido que as bactérias desnitrificantes são as principais consumidoras de etanol em lodos ativados (GERARDI, 2003), entretanto, no caso da inativação deste grupo (comprovado pela taxa de desnitrificação), o consumo deste co-substrato pode ter sido realizado por outros grupos microbianos que sobreviveram ao tratamento térmico.

Em relação a proporção dos ácidos orgânicos voláteis nos reatores D e CD (Tabela 5-31) verificou-se que ácido acético, propiônico e isovalérico foram os principais compostos produzidos nesses sistemas. Constatou-se concentrações no tempo final dos reatores D de 185,8 mg.L $\mathrm{L}^{-1}, 81,2 \mathrm{mg} . \mathrm{L}^{-}$ ${ }^{1}$ e 44,8 mg.L $\mathrm{L}^{-1}$ para os ácidos acético, propiônico e isovalérico, respectivamente. Evidenciou-se também concentrações no tempo final dos reatores CD de 108,4 mg.L $\mathrm{L}^{-1}, 26,6 \mathrm{mg} . \mathrm{L}^{-1}$ e 20,3 mg.L $\mathrm{L}^{-1}$, para os ácidos acético, propiônico e isovalérico, respectivamente. 
Tabela 5-31 Porcentagem e concentração de cada ácido orgânico volátil nos reatores DT0 (reator desnitrificante no tempo 0 dias), DT1 (reator desnitrificante no tempo 78 dias), DT2 (reator desnitrificante no tempo 99 dias), CDT0 (reator controle desnitrificante no tempo 0 dias), CDT1 (reator controle desnitrificante no tempo $\mathbf{7 8}$ dias) e CDT2 (reator controle desnitrificante no tempo 99 dias).

\begin{tabular}{cccccccccc}
$\begin{array}{c}\text { Amostr } \\
\text { a }\end{array}$ & $\begin{array}{c}\text { Unidad } \\
\mathrm{e}\end{array}$ & Etanol & $\begin{array}{c}\text { Ac. } \\
\text { Acético }\end{array}$ & $\begin{array}{c}\text { Ac. } \\
\text { Propiônico }\end{array}$ & $\begin{array}{c}\text { Ac. } \\
\text { Isobutírico }\end{array}$ & $\begin{array}{c}\text { Ac. } \\
\text { Butírico }\end{array}$ & $\begin{array}{c}\text { Ac. } \\
\text { Isovalérico }\end{array}$ & $\begin{array}{c}\text { Ac. } \\
\text { Capróico }\end{array}$ & TOTAL \\
\hline DT0 & mg.L-1 & 2442,11 & 20,23 & 16,68 & 0 & 18,42 & 18,13 & 8,93 & 2524,50 \\
DT1 & mg.L-1 & 4,43 & 403,19 & 28,01 & 22,52 & 18,44 & 19,66 & 9,20 & 520,75 \\
DT2 & mg.L-1 & 0 & 185,86 & 81,26 & 44,87 & 18,86 & 48,73 & 9,98 & 405,28 \\
\hline DT0 & $\%$ & 96,74 & 0,80 & 0,66 & 0 & 0,73 & 0,72 & 0,35 & 100,00 \\
DT1 & $\%$ & 0,85 & 77,42 & 5,38 & 4,32 & 3,54 & 3,77 & 1,77 & 100,00 \\
DT2 & $\%$ & 0 & 45,86 & 20,05 & 11,07 & 4,65 & 12,02 & 2,46 & 100,00 \\
\hline CDT0 & mg.L-1 & 2360,65 & 26,96 & 17,56 & 0 & 18,36 & 19,62 & 8,91 & 2452,06 \\
CDT1 & mg.L-1 & 9,11 & 125,75 & 0 & 0 & 27,28 & 23,44 & 11,34 & 237,81 \\
CMT2 & mg.L-1 & 4,44 & 108,45 & 26,64 & 20,36 & 21,09 & 21,74 & 8,95 & 234,79 \\
\hline CDT0 & $\%$ & 96,27 & 1,10 & 0,72 & 0 & 0,75 & 0,80 & 0,36 & 100,00 \\
CDT1 & $\%$ & 3,83 & 52,88 & 0 & 0 & 11,47 & 9,86 & 4,77 & 100,00 \\
CMT2 & $\%$ & 1,89 & 46,19 & 11,35 & 8,67 & 8,98 & 9,26 & 3,81 & 100,00 \\
\hline
\end{tabular}




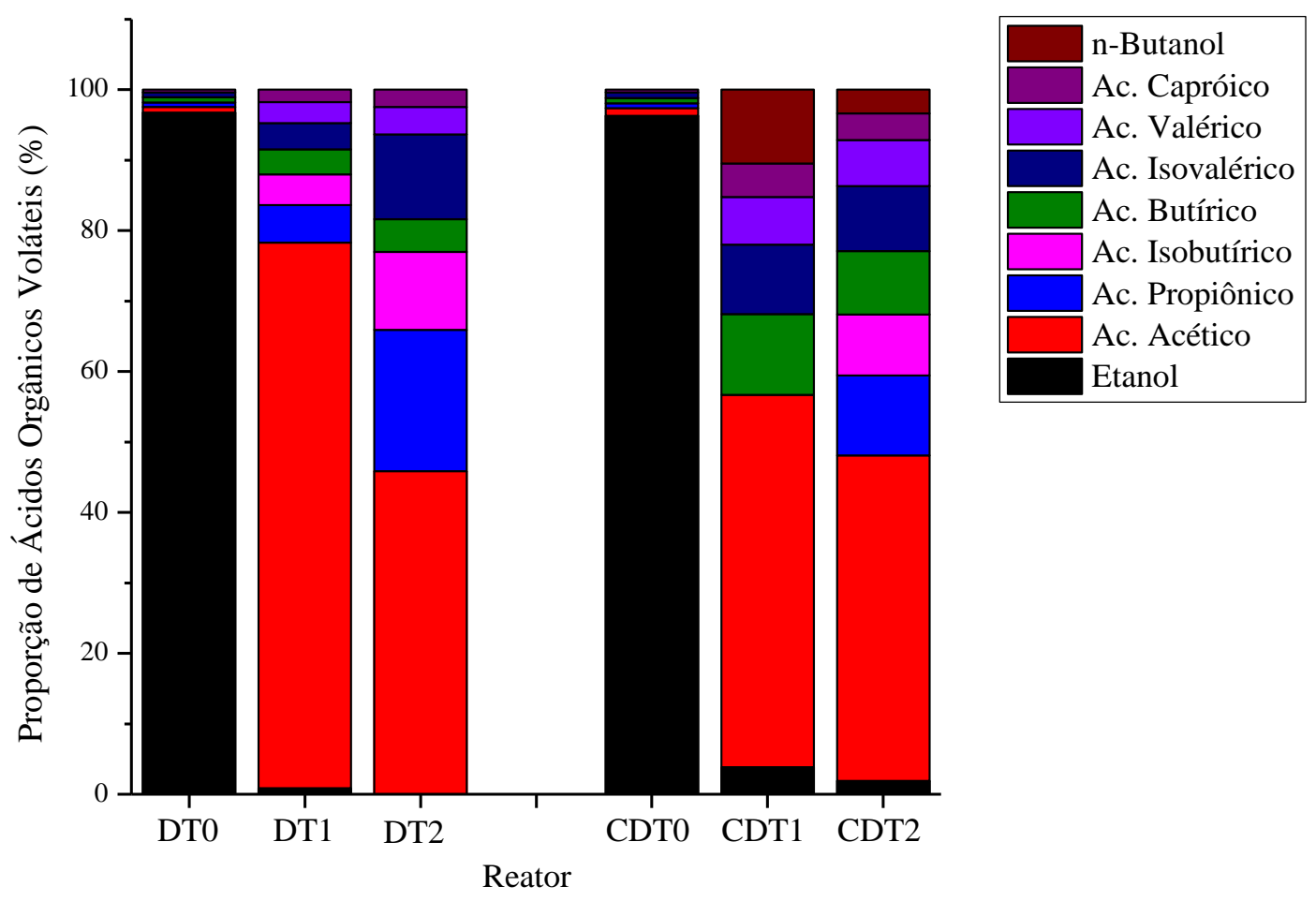

Figura 5-33 Proporção de cada ácido orgânico volátil nos reatores DT0 (reator desnitrificante no tempo 0 dias), DT1 (reator desnitrificante no tempo 78 dias), DT2 (reator desnitrificante no tempo 99 dias), CDT0 (reator controle desnitrificante no tempo 0 dias), CDT1 (reator controle desnitrificante no tempo 78 dias) e CDT2 (reator controle desnitrificante no tempo 99 dias).

\subsubsection{Remoção de PCB}

Similar ao observado para os reatores do Ensaio de Remoção de PCB na condição anaeróbia, por meio das análises preliminares da amostra dos reatores em batelada sob condição anóxica verificou-se que a matriz interferiu diretamente na determinação do PCB. Assim, o método de adição do padrão, ou Standard addiction, foi utilizado para quantificar a amostra dos reatores sob condição anóxica.

Para tanto, analisou-se a remoção de PCB nos reatores em batelada desnitrificantes (D), com etanol (598,9 mg.L $\left.\mathrm{L}^{-1}\right)$, nitrato (1.652,2 mg.. $\left.\mathrm{L}^{-1}\right)$, PCB (1,5 mg.L $\mathrm{L}^{-1}$ ) e inóculo ativo (Figura A. 13 a Figura A. 18, apêndice) no tempo inicial (T0), com 78 dias de operação (T1) e no tempo final, com 99 dias de operação (T2) e nos reatores controle (CM), com etanol (598,9 mg. $\left.\mathrm{L}^{-1}\right)$, nitrato $\left(1.652,2 \mathrm{mg} . \mathrm{L}^{-1}\right), \mathrm{PCB}$ (1,5 mg. $\left.\mathrm{L}^{-1}\right)$ e inóculo inativo (Figura A. 19 a Figura A. 24, apêndice) no tempo inicial (T0) e no tempo final, com 99 dias de operação (T2).

A remoção de poluentes orgânicos em reatores biológicos envolve, tanto o mecanismo de biodegradação, quanto de biossorção (TSEZOS; BELL, 1989), entretanto a cinética de biossorção por meio de isotermas não foi avaliado neste trabalho, como esclarecido no Ensaio de Remoção de PCB sob condição fermentativa-metanogênica. 
Assim, a análise de biossorção foi avaliada por meio da análise da concentração dos congêneres de PCB nos reatores controle (CD), inoculados com biomassa inativa no tempo inicial (T0) e final de operação (T2) (Tabela 5-17). Como as concentrações para cada congênere permaneceu constante ao longo do tempo, o valor de adsorção foi calculada a partir dessas concentrações e da concentração teórica adicionada de cada congênere $\left(1,5 \mathrm{mg} \cdot \mathrm{L}^{-1}\right)$.

Observou-se diferentes concentrações iniciais para cada congênere (Tabela 5-32). Verificou-se concentrações mais elevadas para os congêneres PCB 10, 28, 52 e 153, de 1,13 mg.L $\mathrm{L}^{-1}$, 1,33 mg.L $\mathrm{L}^{-1}$, 1,35 mg.L $\mathrm{L}^{-1}$ e 1,43 mg. $\mathrm{L}^{-1}$, respectivamente. Em contrapartida, notou-se concentrações menores para o PCB 138 e 180 , de $0,36 \mathrm{mg} . \mathrm{L}^{-1}$ e $0,17 \mathrm{mg} . \mathrm{L}^{-1}$, respectivamente.

Comparando-se as diferentes concentrações dos congêneres de PCB foi possível inferir que exista diferentes afinidades desses congêneres de PCB com a biomassa. A diferença entre as concentrações biossorvidas pode ser explicada pelo variado número de átomos de cloro em cada molécula e posição, o qual confere distintas conformações moleculares e características particulares a cada congênere.

Patureau; Trably (2006) verificaram para lodos anaeróbios maior capacidade de induzir perdas abióticas de PCB. Os autores observaram entre 10 a 30\% de perda para os PCB 52, 101, 118, 138, 153 e 180. Neste trabalho foram encontrados valores de biossorção de $25 \%, 11 \%, 10 \%, 5 \%, 75 \%$ e $88 \%$ para as PCBs 10, 28, 52, 153, 138 e 180, respectivamente, para condição anóxica. Provavelmente, a diferença observadas neste trabalho em relação aos resultados de Patureau e Trably (2006) estejam relacionadas com a influência, tanto da estrutura molecular do PCB (PATUREAU; TRABLY, 2006), quanto das características da biomassa usada como inóculo dos reatores anaeróbios (TSEZOS; WANG, 1991) na adsorção.

Ademais, como já no tempo inicial de operação (T0) a biossorção foi evidenciada, foi possível inferir que o PCB foi prontamente adsorvido na biomassa.

Tabela 5-32 Concentração dos seis congêneres de PCB (PCB 10, 28, 52, 153, 138 e 180) nos reatores controle (CD) ao longo do tempo de operação (T0 e T2) do ensaio em batelada.

\begin{tabular}{|c|c|c|c|c|c|c|}
\hline & PCB 10 & PCB 28 & PCB 52 & PCB 153 & PCB 138 & PCB 180 \\
\hline & $\mathrm{CD}^{1}$ & $\mathrm{CD}^{1}$ & $\mathrm{CD}^{1}$ & $\mathrm{CD}^{1}$ & $\mathrm{CD}^{1}$ & $\mathrm{CD}^{1}$ \\
\hline $\mathrm{T} 0$ & 1,13 & 1,33 & 1,35 & 1,43 & 0,36 & 0,17 \\
\hline $\mathrm{T} 2$ & 1,13 & 1,34 & 1,36 & 1,42 & 0,38 & 0,2 \\
\hline Biossorção $^{2}$ & 0,37 & 0,17 & 0,15 & 0,08 & 1,13 & 1,32 \\
\hline \% biossorção & 24,7 & 11,0 & 9,7 & 5,0 & 75,3 & 87,7 \\
\hline
\end{tabular}

Pelos resultados observados, por meio da análise de adsorção de PCB nas condições dos reatores controle pode-se inferir que ocorreu remoção e degradação de PCB nos reatores desnitrificantes. Verificou-se remoção de PCB nos reatores desnitrificantes (D) de 1,02 mg.L $\mathrm{L}^{-1}, 0,85 \mathrm{mg} . \mathrm{L}^{-1}, 1,31 \mathrm{mg} . \mathrm{L}^{-}$ 1, 1,02 mg.L $\mathrm{L}^{-1}, 0,03 \mathrm{mg} . \mathrm{L}^{-1}$ e $0,09 \mathrm{mg} . \mathrm{L}^{-1}$ para os PCBs 10, 28, 52, 153, 138 e 180, respectivamente (Tabela 5-33), com remoção média de PCBs totais de 0,72 mg.L $\mathrm{L}^{-1}(74,0 \%)$.

No Ensaio de Remoção de PCB sob condição fermentativa-metanogênica verificou-se remoção de PCB de 0,92 mg.L $\mathrm{L}^{-1}, 0,19 \mathrm{mg} . \mathrm{L}^{-1}, 0,18 \mathrm{mg} . \mathrm{L}^{-1}, 0,07 \mathrm{mg} . \mathrm{L}^{-1}, 0,55 \mathrm{mg} . \mathrm{L}^{-1}$ e $0,47 \mathrm{mg} . \mathrm{L}^{-1}$ para os PCBs $10,28,52,153,138$ e 180 , respectivamente. 
Comparando-se os resultados reportados neste trabalho sob condição desnitrificante (remoção de PCB de 1,02 mg.L $\mathrm{L}^{-1}$, 0,85 mg. $\mathrm{L}^{-1}$, 1,31 mg.L. $\mathrm{L}^{-1}, 1,02 \mathrm{mg} . \mathrm{L}^{-1}, 0,03 \mathrm{mg} . \mathrm{L}^{-1}$ e $0,09 \mathrm{mg} . \mathrm{L}^{-1}$ para os PCBs 10, 28, 52, 153, 138 e 180, respectivamente) e aqueles do Ensaio de Remoção de PCB sob condição fermentativa-metanogênica (remoção de PCB de $0,92 \mathrm{mg} \cdot \mathrm{L}^{-1}, 0,19 \mathrm{mg} \cdot \mathrm{L}^{-1}, 0,18 \mathrm{mg} \cdot \mathrm{L}^{-1}, 0,07 \mathrm{mg} \cdot \mathrm{L}^{-1}$, 0,55 mg.L $\mathrm{L}^{-1}$ e $0,47 \mathrm{mg} . \mathrm{L}^{-1}$ para os PCBs $10,28,52,153,138$ e 180, respectivamente), pode-se evidenciar que para a primeira condição, a remoção dos PCBs 28,52 e 153, foi favorecida e a remoção dos PCBs 138 e 180 foi reduzida.

A distinta remoção de PCB pode ter ocorrido por diferença na comunidade microbiana no inóculo (lodos ativados e UASB). Chang et al. (1999) concluíram que a capacidade de degradação de PCB está relacionada com a fonte de inóculo utilizado nos reatores, bem como os doadores de elétrons e receptores finais.

Ao mesmo tempo, a partir dos resultados apresentados neste trabalho pode-se inferir que o inóculo anóxico não adaptado foi capaz de remover PCB em 99 dias.

Tabela 5-33 Concentração dos seis congêneres de PCB (PCB 10, 28, 52, 153, 138 e 180) nos reatores desnitrificantes (D) ao longo do tempo de operação (T0, T1 e T2) do ensaio em batelada.

\begin{tabular}{|c|c|c|c|c|c|c|c|}
\hline & PCB 10 & PCB 28 & PCB 52 & PCB 153 & PCB 138 & PCB 180 & PCBs totais ${ }^{2}$ \\
\hline T0 & 1,13 & 1,45 & 1,37 & 1,42 & 0,30 & 0,17 & 0,97 \\
\hline $\mathrm{T} 1$ & 0,17 & 0,44 & 0,48 & 1,28 & 0,27 & 0,08 & 0,45 \\
\hline $\mathrm{T} 2$ & 0,11 & 0,60 & 0,06 & 0,40 & 0,27 & 0,08 & 0,25 \\
\hline Remoção $^{1}$ & $\bar{~} 1,02$ & 0,85 & 1,31 & 1,02 & 0,03 & 0,09 & 0,72 \\
\hline$\%$ remocao & 90,27 & 58,62 & 95,62 & 71,91 & 10,00 & 52,94 & 73,99 \\
\hline
\end{tabular}

Aos 78 dias de operação dos reatores desnitrificantes (T1) verificou-se diminuição acentuada na concentração apenas dos PCBs menos clorados, PCB 10, 28 e 52 (de 0,96 mg.L $\mathrm{L}^{-1}, 1,01 \mathrm{mg} . \mathrm{L}^{-1}$ e 0,89 mg.L ${ }^{-1}$, respectivamente) (Figura 5-34). Entre 78 e 99 dias (T1 e T2, respectivamente) de operação dos reatores verificou-se diminuição acentuada da concentração do PCB 52 e $153\left(0,42 \mathrm{mg} . \mathrm{L}^{-1}\right.$ e $0,88 \mathrm{mg} . \mathrm{L}^{-}$ ${ }^{1}$, respectivamente), e ligeiro aumento da concentração do PCB 28 (de $0,16 \mathrm{mg} \cdot \mathrm{L}^{-1}$ ).

Dudková; Demnerová; Bedard (2012) evidenciaram a desalogenação de hexa-, hepta-, octa- e nonaclorobifenil observaram como consequência diminuição dos PCB mais clorados e aumento dos menos clorados no meio reacional. Assim, provavelmente nos reatores do presente estudo, os PCBs mais clorados foram removidos pela comunidade anóxica e consequentemente, ligeiro acréscimo da concentração do PCB menos clorado (PCB 28).

Desse modo, pode-se inferir que no primeiro período de operação (de 0 a 78 dias) a remoção foi efetiva para os PCBs menos clorados (PCB 10, 28 e 52) e no segundo período de operação (de 78 a 99 dias) foi efetiva para os PCB mais clorados (PCB 52 e 153). 


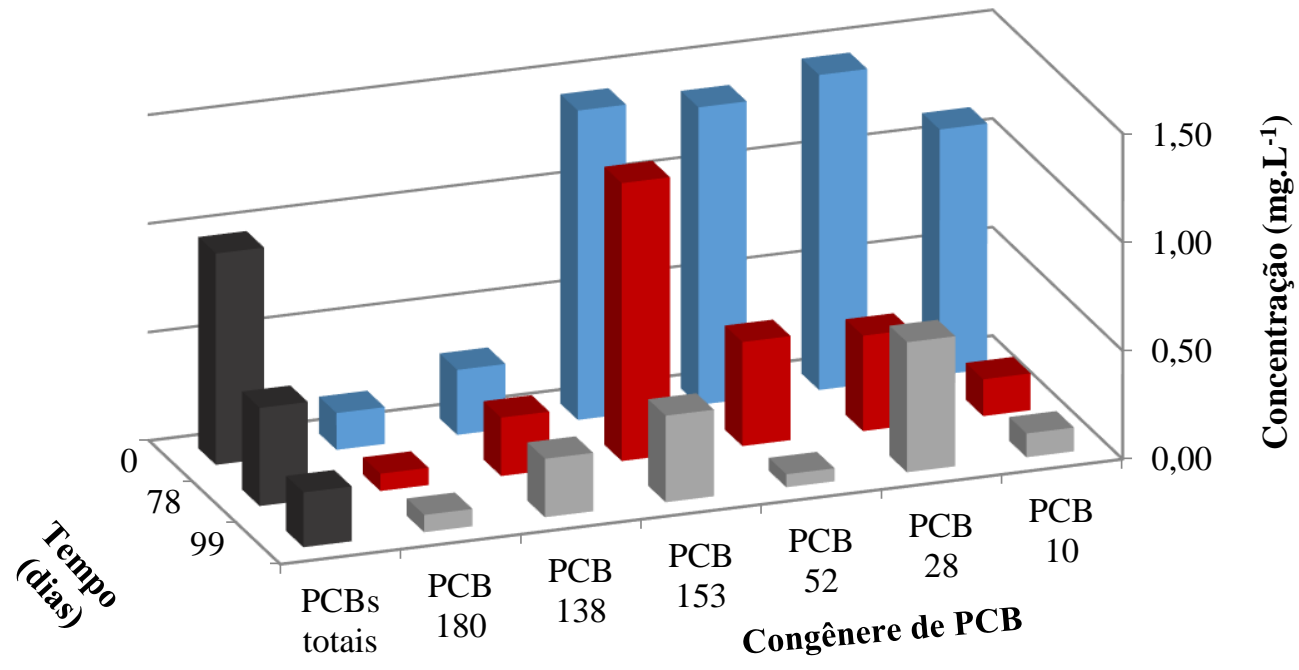

Figura 5-34 Concentração dos seis congêneres de PCB (PCB 10, 28, 52, 153, 138 e 180) e concentração média dos PCBs ( $\bullet$ PCBs totais) nos reatores desnitrificantes (D) ao longo do tempo de operação ( $\square$ T0, $\backsim$ T1 e $\backsim$ T2) do ensaio em batelada.

Ademais, a partir dos resultados de remoção de PCB dos reatores desnitrificantes (D) e controle (CD) foi possível atribuir a remoção de PCB ao estabelecimento do metabolismo desnitrificante, visto que a remoção de PCB foi observada somente nos reatores em que o metabolismo desnitrificante foi estabelecido (D).

\subsection{3 Índices ecológicos}

A região hipervariável V3-V4 do gene RNAr 16S foi utilizada para o sequenciamento massivo das biomassas dos reatores desnitrificantes do Ensaio de Remoção de PCB. Obteve-se total de 185.977 sequências (somando as duas amostras do início e final da operação) (Tabela 5-34).

Dentre as sequencias selecionadas, 118.838 e 67.139 delas foram atribuídas para cada amostra, respectivamente, ao inóculo, ou reator no tempo inicial de operação (DT0), e as amostras dos reatores no tempo final de operação (DT2). Ao todo foram definidas 6.678 UTOs, sendo 3.563 das UTOs atribuídas a biomassa do DT0, e 3.115 UTOs atribuídas a biomassa do DT2.

Tabela 5-34 Quantidade de sequencias e UTOs atribuídas a cada amostra (97\% de similaridade).

\begin{tabular}{ccc} 
Amostra & Sequencias & UTOs \\
\hline Inóculo ou reator no tempo inicial de operação (DT0) & 118.838 & 3.563 \\
\hline Reator no tempo final de operação (DT2) & 67.139 & 3.115 \\
\hline TOTAL & 185.977 & 6.678 \\
\hline
\end{tabular}

Para avaliar a complexidade da comunidade microbiana das amostras dos reatores em batelada desnitrificante, DT0 e DT2, foram calculados índices ecológicos de diversidade, dominância, equitabilidade e riqueza (Tabela 5-35). 
Por meio da análise do índice de Simpson (1-D), complemento do índice de dominância, foi possível verificar igual valor para ambas as amostras, de 0,96 para DT0 e DT2. Desse modo, pode-se inferir que não houve diferença na dominância em função do tempo de operação dos reatores.

Por meio da análise do índice de Shannon-Wienner (H') verificou-se que no final da operação (DT2) os valores obtidos foram relativamente menores $(4,58)$, quando comparados com aqueles para as amostras iniciais (DT0), ou seja, de 4,78. Pode-se inferir que no final da operação verificou-se menor diversidade da comunidade microbiana.

Verificou-se também abundancia distinta entre as espécies no final da operação (DT2) $(0,57)$, quando comparados com aqueles para as amostras iniciais (DT0) $(0,58)$ por meio da análise de equitabilidade de Pielou (J').

A cobertura (C) foi utilizada para avaliar se o tamanho da biblioteca de UTOs era suficiente para estimar índices ecológicos confiáveis e significativos. Os valores de C observados foram 98,6\% e $97,4 \%$, respectivamente, para as amostras DT0 e DT2. Por meio dessa análise obteve-se boa representatividade das espécies de microrganismos identificados, cujos índices ecológicos calculados foram confiáveis e significativos (PENG et al., 2012).

Comunidades naturais microbianas normalmente são caracterizadas pela presença de algumas espécies com muitos indivíduos, e muitas espécies com poucos indivíduos. Na presença de um fator limitante pode ocorrer alterações detectáveis na estrutura da comunidade microbiana (WILHM; DORRIS, 1968). Peng et al. (2012) demonstraram que ao se enriquecer uma comunidade com adições temporais de um composto tóxico, como o tetra-bromobisfenol, ocorreu seleção de microrganismos resistentes e capazes de degradar o composto.

Verificou-se para as amostras finais (DT2) tendência a baixos valores de diversidade $(0,58) \mathrm{e}$ equitabilidade $(0,57)$ de espécies. Com isso, levanta-se a hipótese de que a estrutura da comunidade microbiana é diferente nos reatores com PCB em relação àquela do inóculo.

Tabela 5-35 Índices ecológicos de diversidade, dominância, equitabilidade e riqueza para o Domínio Bacteria nas amostras DT0 e DT2.

\begin{tabular}{ccc} 
Número de Sequencias & DT0 & DT2 \\
\cline { 2 - 3 } & 118.838 & 67.139 \\
\hline UTOs & 3.563 & 3.115 \\
\hline Simpson (1-D) ou Doninância & $0,961 \pm 0,001$ & $0,960 \pm 0,001$ \\
\hline Shannon-Wienner (H') ou Diversidade & $4,78 \pm 0,02$ & $4,58 \pm 0,02$ \\
\hline Pielou (J') ou Equitabilidade & $0,585 \pm 0,002$ & $0,569 \pm 0,003$ \\
\hline Singletons & 1.613 & 1.744 \\
\hline Cobertura (C) & $98,64 \%$ & $97,40 \%$ \\
\hline
\end{tabular}

Por fim, por meio da análise das curvas de rarefação verificou-se maior riqueza para amostra do reator no tempo inicial (DT0) quando comparada com aquela do reator no tempo final (DT2) (Figura 5-35). Atribuiu-se então a menor riqueza da amostra do reator DT2 ao PCB e, consequentemente, seleção de microrganismos resistentes a este composto. 


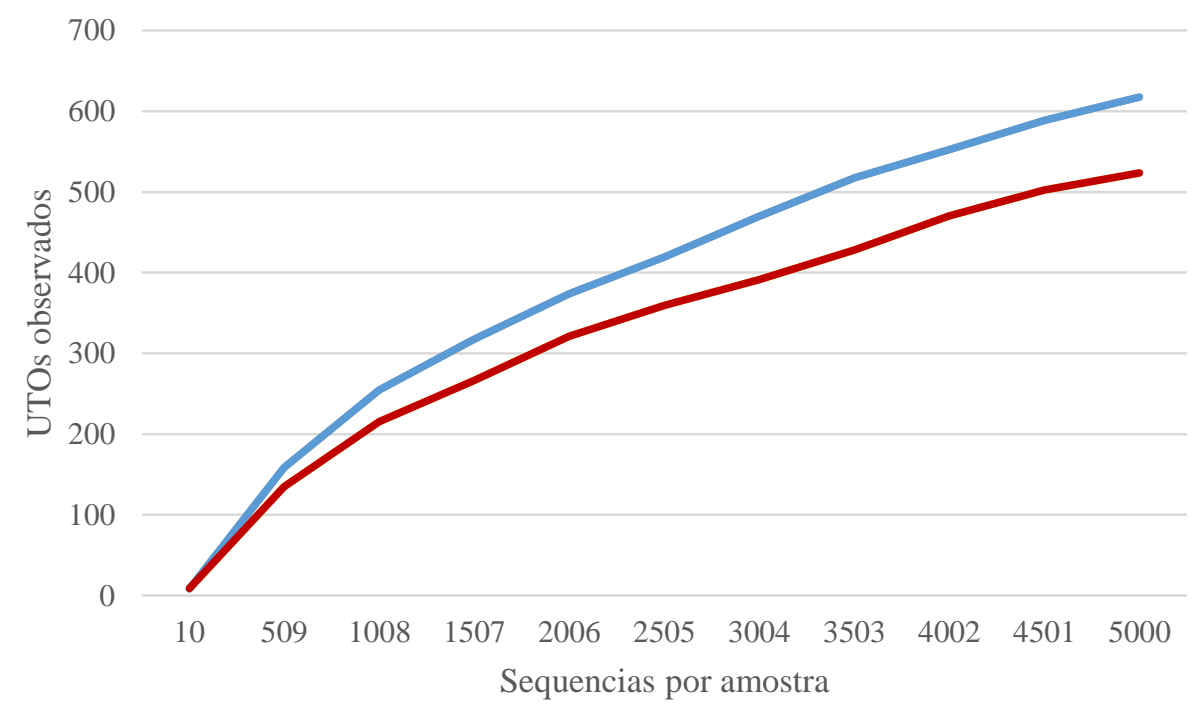

Figura 5-35 Curva de rarefação definida das sequencias de amostras do inóculo, ou reator desnitrificante no tempo incial ( - DT0) e tempo final (-DT2) $(97 \%$ de similaridade).

\subsubsection{Análise Taxonômica}

Por meio da aplicação do RDP-classifier obteve-se classificação em filos do Domínio Bacteria para cada amostra. Em relação aos filos observados nas amostras iniciais (DT0) e finais (DT2) dos reatores desnitrificantes em batelada destaca-se a identificação de representantes de Proteobacteria (3349\%), Chloroflexi (19-3\%), Firmicutes (15-24\%), Bacteroidetes (10-5\%) e Acidobacteria (6-0,9\%) (Figura 5-36).

Pode-se mencionar que para as amostras DT0 e DT2 houve mudança na composição microbiana dos reatores em batelada. Ao longo do tempo de operação verificou-se diminuição na abundância relativa de Chloroflexi, de $19 \%$ para 3\%, Bacteroidetes, de $10 \%$ para 5\% e Acidobacteria, de 6\% para 0,9\%. Em contrapartida, para outros filos verificou-se aumento da abundância relativa, como por exemplo para Proteobacteria, de 33\% para 49\% e Firmicutes, de 15\% para 24\%.

Pode-se salientar ainda que ocorreu alteração da composição microbiana para os representantes do filo Proteobacteria (Figura 5-21). Ao longo do tempo de operação verificou-se alteração da abundância relativa de Alpha-proteobacteria, (de 54\% para 16\%), Beta-proteobacteria (9\% para 9,3\%), Delta-proteobacteria (de $8 \%$ para $2 \%$ ), Episilon-proteobacteria (de $1 \%$ para $0 \%$ ) e Gammaproteobacteria (de $27 \%$ para $72 \%$ ).

Desse modo, pode-se destacar que houve seleção na microbiota dos reatores anóxicos, provavelmente relacionada com a adição de PCB nos reatores. Destaca-se a capacidade das bactérias pertencentes ao filo Firmicutes em realizar a desalogenação, a qual tem sido descrita com frequência na literatura (KITAGAWA; KAMAGATA, 2014), bem como, a identificação de membros pertencentes a Proteobacteria em sistemas onde foi comprovada a remoção de PCB (CORREA et al., 2010; MERCIER et al., 2014). 


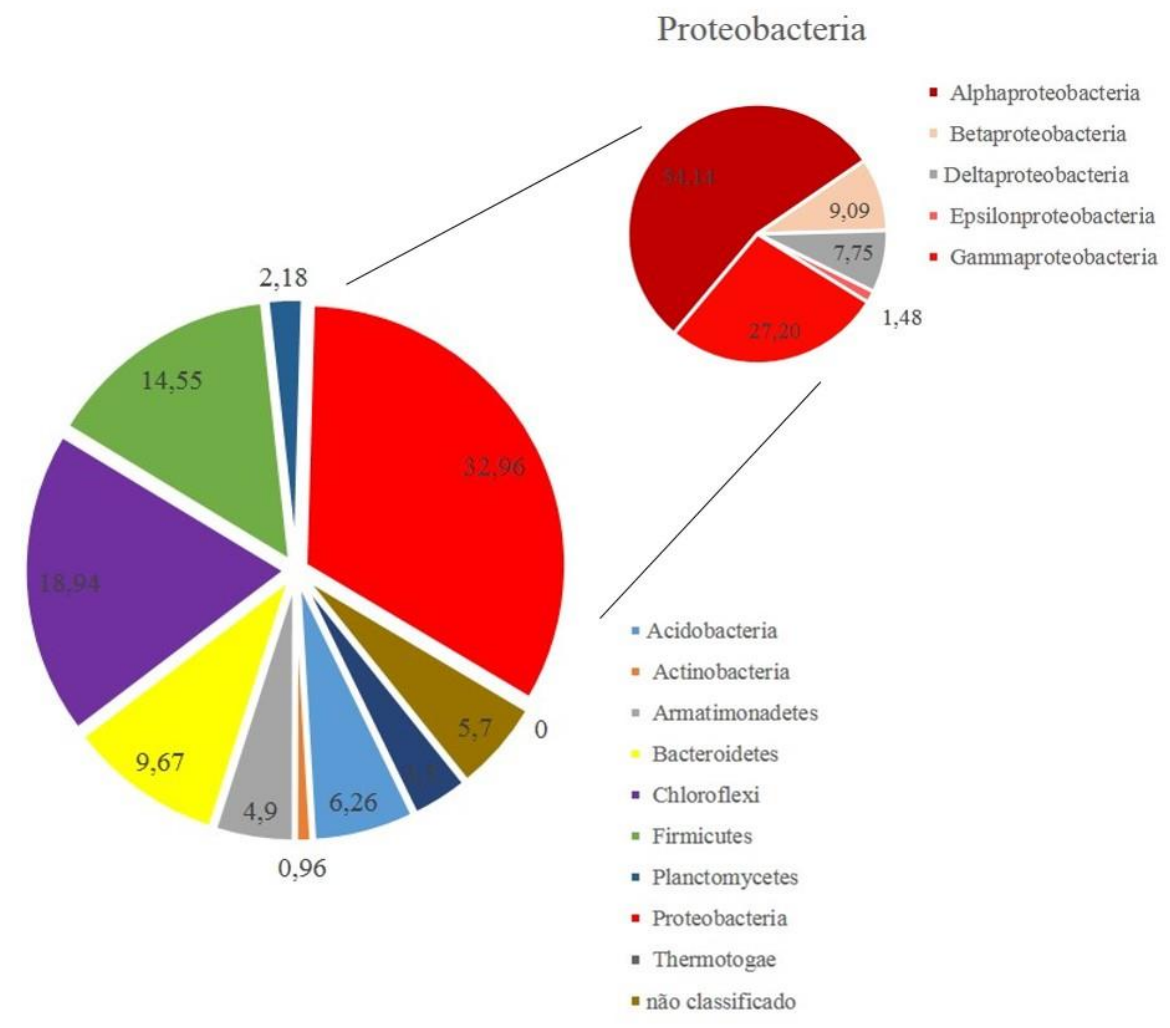

(a)

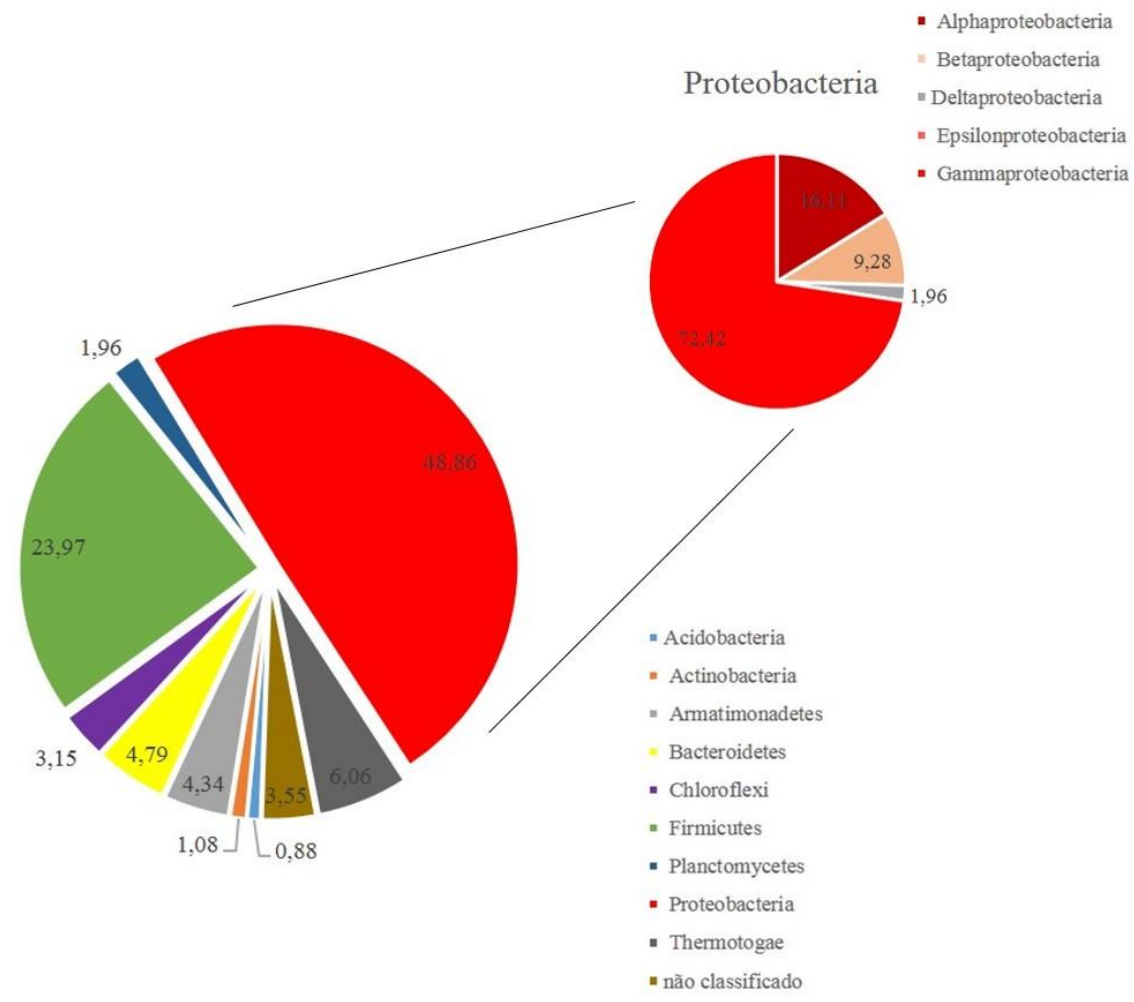

(b)

Figura 5-36 Abundância relativa dos filos e classes do grupo de Proteobacteria (similaridade 97\%) nas amostras iniciais DT0 (a) e finais DT2 (b). 
Devido a quantidade de gêneros do Domínio Bacteria classificados (75-180) restringiu-se a descrição dos 10 grupos (ordem, família, gênero e espécie) com maior abundância relativa em cada amostra, DT0 (Tabela A. 3, apêndice) e DT2 (Tabela A. 4, apêndice). A comparação entre os grupos identificados na amostra inicial (DT0) e final (DT2) estão apresentado na Figura 5-37.

Dentre esses grupos, representantes de sete deles (Rhizobiales, Clostridiaceae, Caldilineaceae, Prosthecobacter, Chloracidobacteria, Thermomonas e Kouleothrix) foram identificados apenas no inóculo, e portanto relacionado com a pré-existência desses microrganismos no lodo anóxico. Representantes de outros três (Chitinophagaceae, Hyphomonadaceae e Fimbriimonas) foram identificados nas amostras DT0 e DT2 e relacionados com a presença no inóculo e atividade metabólica que favorecia sua manutenção no sistema. Outros dois grupos (Chitinophagaceae e Hyphomonadaceae) foram relacionados com o metabolismo estabelecido nos reatores desnitrificantes e quatro grupos (Aeromonadaceae, Lutispora, Sedimentibacter e Thermotogaceae), foram identificados apenas na amostra DT2, os quais possivelmente desempenharam papel importante na remoção do PCB.

Representantes pertencentes a ordem Rhizobiales, as famílias Clostridiaceae e Caldilineaceae e ao gênero Prosthecobacter foram identificados em sistemas de lodos ativados. Tais representantes foram identificados em estações de tratamento de lodos ativados de diferentes efluentes com distintos parâmetros operacionais e localidades geográficas (Wang et al., 2012).

No presente estudo verificou-se para representantes da ordem Rhizobiales, das famílias Clostridiaceae e Caldilineaceae e gênero Prosthecobacter abundancia relativa de 3,9\%, 9,1\%, 3,5\%, $4,0 \%$, respectivamente, para DT0. Todavia, para DT2 verificou-se abundância relativa próxima a $0 \%$ para todos esses grupos. Neste sentido, a identificação destes grupos de microrganismos, neste trabalho, foi relacionada com a natural presença deles no inóculo proveniente de sistema de lodos ativados, sendo possível sugerir que estes microrganismos foram afetados ou inibidos pelo PCB nos reatores desnitrificantes.

A classe Chloroflexi é representado por bactérias filamentosas (KUEVER; RAINEY; WIDDEL, 2005) que comumente são consideradas responsáveis pela formação de flocos em estações de tratamento com lodos ativados (BEER et al., 2002). Nesta classe estão incluídas representantes do gênero Kouleothrix, primeiramente isolado de lodos ativados e capaz de utilizar carboidratos e biopolímeros (BEER et al., 2002; KOHNO; SEI; MORI, 2002). Identificou-se elevada abundância $(15,2 \%)$ deste gênero no DT0, que pode ser explicada pela sua presença no tratamento de lodos ativados. A baixa abundância relativa em DT2 (próximo a $0 \%$ ) pode ser relacionada com a sensibilidade deste grupo ao PCB.

A familia Chitinophagaceae possui representantes, tanto, aeróbios, quanto anaeróbios facultativos, com capacidades fermentativas limitadas e que realizam o metabolismo desnitrificante (KÄMPFER; LODDERS; FALSEN, 2011). Ainda, representantes desta família foram encontrados em estações de tratamento de lodos ativados estudadas por Wang et al. (2012) com elevada taxa de abundancia relativa (entre $7 \%$ e 59\%). No presente estudo, verificou-se abundancia relativa deste grupo de $6,7 \%$ e $1,1 \%$, respectivamente para amostras DT0 e DT2.

Membros da família Hyphomonadaceae, principalmente isolados de habitats marinhos, formam um clade robusto que apresenta similaridades morfológica, fisiológica e biológica (MOORE; WEINER; GEBERS, 1984; SCHLESNER et al., 1990; ABRAHAM et al., 1999; STRÖMPL et al., 2003; LEE et al., 2005). Seus representantes apresentam metabolismo aeróbio e anaeróbio facultativo e algumas 
espécies são capazes de realizar desnitrificação (LEE et al., 2005). No presente estudo, verificou-se abundancia relativa deste grupo de $5,7 \%$ e 2,4\%, respectivamente para amostras DT0 e DT2.

Assim, neste trabalho, observou-se elevada abundancia relativa em DT0 de membros da família Chitinophagaceae $(6,7 \%)$ e Hyphomonadaceae $(5,7 \%)$. A partir desses resultados pode-se supor que estes microrganismos contribuíram para o estabelecimento do metabolismo desnitrificante nos reatores no início da operação, entretanto com o consumo do nitrato adicionado desde o tempo T1 de operação, dia 78 (de 1.652,2 mg.L $\mathrm{L}^{-1}$ a $0 \mathrm{mg} . \mathrm{L}^{-1}$ ), foi possível observar a diminuição desses microrganismos e o estabelecimento de grupos relacionados com a degradação do PCB no final da operação (99 dias).

Verificou-se para quatro grupos, Aeromonadaceae, Lutispora, Sedimentibacter e Thermotogaceae, baixa abundância relativa nas amostras DT0 (de 0,2\%,0\%,0\% e 0\%, respectivamente) e alta abundancia relativa nas amostras DT2, cujas abundâncias relativas obtidas foram $28,4 \%, 8,9 \%$, $8,0 \%$ e $6,1 \%$, respectivamente.

A família Aeromonadaceae é composta por representantes anaeróbios facultativos que realizam a redução do nitrato, mas não a desnitrificação, e são encontrados em lodos, sedimentos e biofilmes (BOONE et al., 2005). Representantes deste grupo foram isolados de amostras de estação de tratamento de água e sedimentos em meio contendo PCB, e foi suposto que estes isolados ou possuíam a capacidade de degradação de PCB ou realizaram a metabolização de nutrientes do inóculo (SAYLER; SHON; COLWELL, 1977).

Shuai et al. (2010) identificaram a microbiota isolada de solos contaminados, crescendo em meio de cultura com nitrato de amônia e PCB como única fonte de carbono. Estes autores utilizaram iniciadores específicos para Pseudomonas fluorescens, e representantes da família Aeromonadaceae foram identificados.

Sayler et al. (1977) e Shuai et al. (2010) indicaram que espécies desta família sejam capazes de realizar a degradação do PCB. Neste sentido a identificação de representantes da família Aeromonadaceae apenas na amostra final do presente trabalho com elevada abundancia relativa $(28,4 \%)$ pode indicar que este grupo foi provavelmente responsável pela remoção de PCB nos reatores.

Lutispora é caracterizado pela termofilia moderada, anaerobiose e quimiorganotrofismo, além da capacidade de formar endósporo (SHIRATORI et al., 2008). Representantes deste gênero foram enriquecidos provenientes de cultura de reator metanogênico termofilico $\left(55^{\circ} \mathrm{C}\right)$ usado no tratamento de resíduos sólidos (SHIRATORI et al., 2008). Membros deste grupo foram identificados também em sistema anaeróbio, onde a mineralização do pentaclorofenol foi alcançada com lactato como única fonte externa de carbono (LI et al., 2013b). A identificação deste grupo no presente estudo (8,9\% de abundância relativa no DT2) pode indicar a existência de representantes mesofilicos que crescem na presença de PCB.

Sedimentibacter é caracterizado por incluir microrganismos anaeróbios que crescem sob condições de desalogenação redutiva, apesar de sua capacidade de remover halogênios não ter sido comprovada (VOS et al., 2011). Representantes desse gênero foram identificados em sedimentos intensamente contaminados por clorofenóis, $\mathrm{PCB}$ e hidrocarbonetos policíclicos aromáticos do Estuário São Vicente (São Paulo, Brasil). Além de membros desse grupo terem sido identificados em reator em batelada sequencial usado no tratamento de lixiviado com remoção de $97 \%$ de N-amoniacal (XIAO et al., 2009). Assim, a abundância relativa nas amostras DT2 de Sedimentibacter $(8,0 \%)$ indica a 
importância deste grupo na remoção do PCB e a possibilidade de estabelecimento desta comunidade em condições anóxicas.

Os representantes da ordem Thermotogales (anaeróbios e fermentativos) são geralmente classificados como termofílicos e hipertermofílicos (KUEVER; RAINEY; WIDDEL, 2005), entretanto recentes trabalhos evidenciaram a presença destes microrganismos em ambientes mesófilos (HOLOMAN et al., 1998; DAHLE et al., 2011; NESBØ et al., 2012; OKADA, 2012; SILVA, 2012). Membros da família Thermotogaceae foram identificados em sistemas marinhos, terrestre, hidrotermal, reservatórios de petróleo (RAVOT et al., 1995; L'HARIDON et al., 2001; KUEVER; RAINEY; WIDDEL, 2005; MIRANDA-TELLO et al., 2007; CHENG et al., 2013). Li et al. (2015) identificaram representantes da família Thermotogaceae em reator anaeróbio que uniu os processos de hidrólise e desnitrificação com altas eficiências de remoção de nitrogênio e compostos aromáticos.

Apesar de nenhum membro desse grupo ter sido comprovadamente responsável pela desalogenação do PCB, ele foi isolado em diversos trabalhos onde a degradação do PCB foi comprovada (HOLOMAN et al., 1998; WU; SOWERS; MAY, 2000; WATTS et al., 2001; YAN; LAPARA; NOVAK, 2006). A presença de representantes deste grupo apenas nas amostras DT2 (com 6,1\% de abundancia relativa) indica que estes microrganismos podem desempenhar importante papel na remoção do PCB.

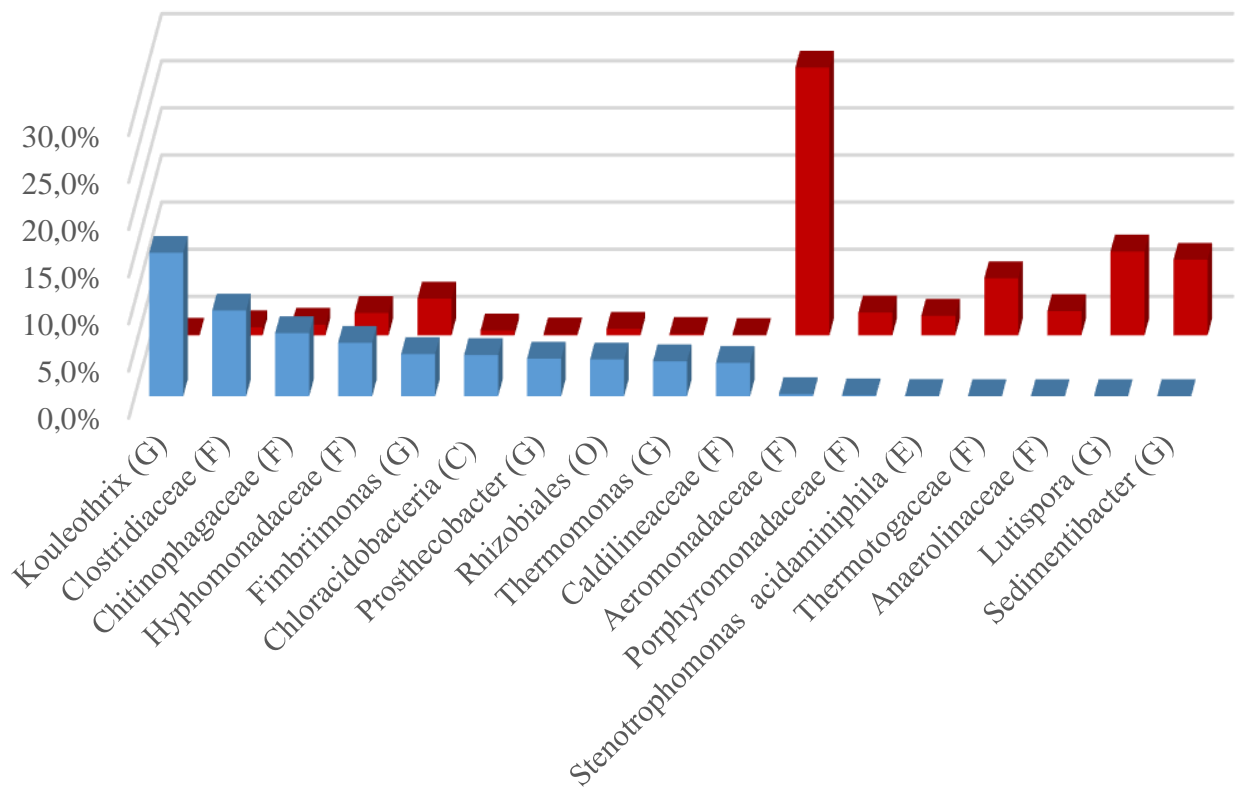

Figura 5-37 Distribuição da abundância relativa dos 10 grupos mais abundantes no início ( $\square$ DT0) e no final (-DT2) da operação dos reatores (97\% de similaridade). (F) representa a classificação em nível de Família, (G) representa a classificação em nível de Gênero e (E) em nível de Espécie. 


\subsubsection{Exames Microscópicos}

A comunidade microbiana dos reatores desnitrificante (D) e controle (CD) do Ensaio de Remoção de PCB foi caracterizada morfologicamente por meio de exames microscópios de contraste de fase e de fluorescência no tempo inicial T0 e final de operação T2 (98 dias).

A partir das análises microscópicas verificou-se a presença de morfologias semelhantes a Euglypha na amostra no tempo inicial (DT0) (Figura 5-38 [a] e [b]), comumente encontradas em lodos ativados (SEVIOUR; NIELSEN, 2010) e ovos de rotíferos. Em ambas as amostras DT0 e DT2 observouse morfologia semelhante a fungo filamentoso e cocos (Figura 5-38 [c], [d], [e] e [f]), entretanto, observou-se presença mais acentuada de morfologia semelhante a fungos filamentosos no tempo final (98 dias). 


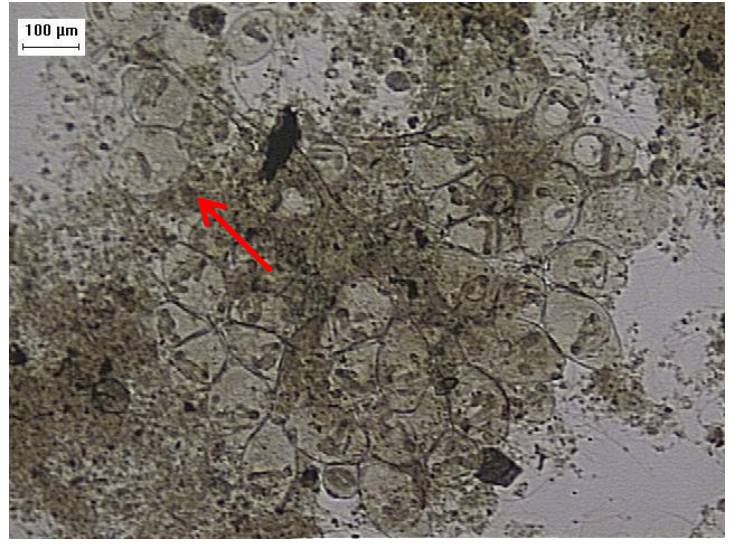

(a)

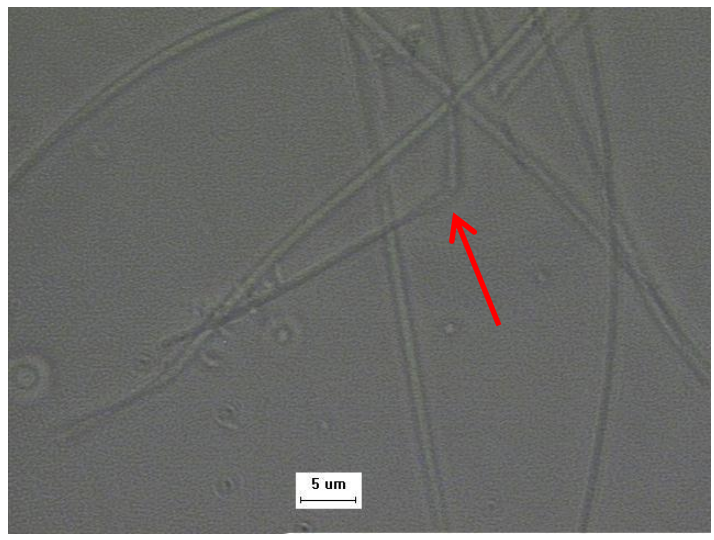

(c)

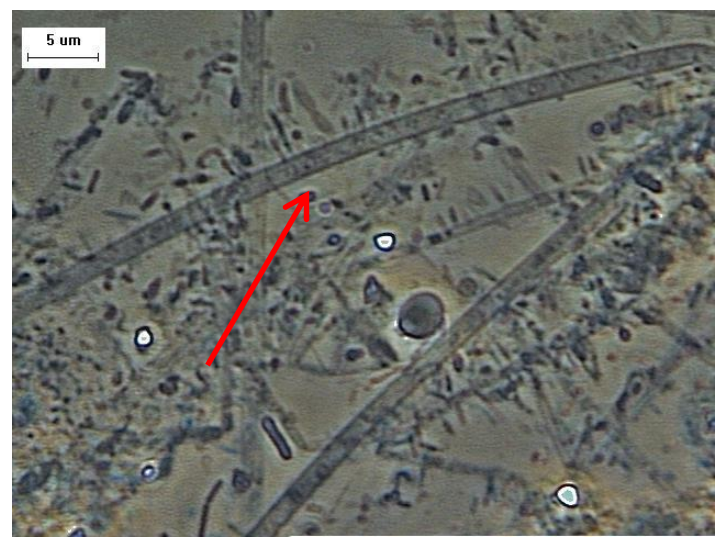

(e)

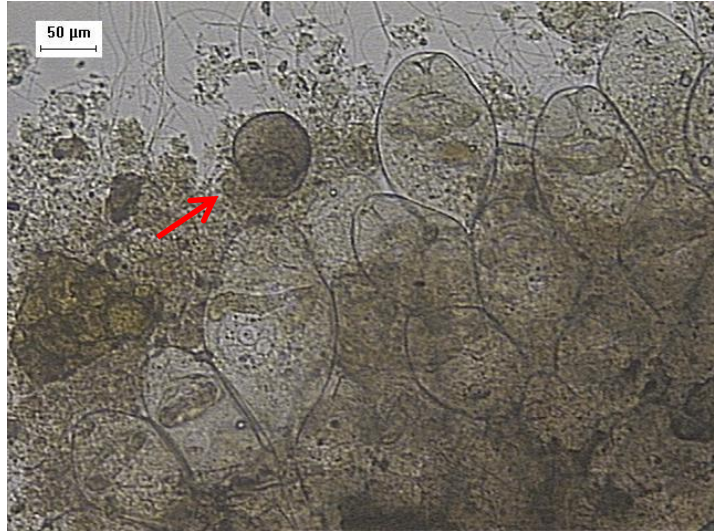

(b)

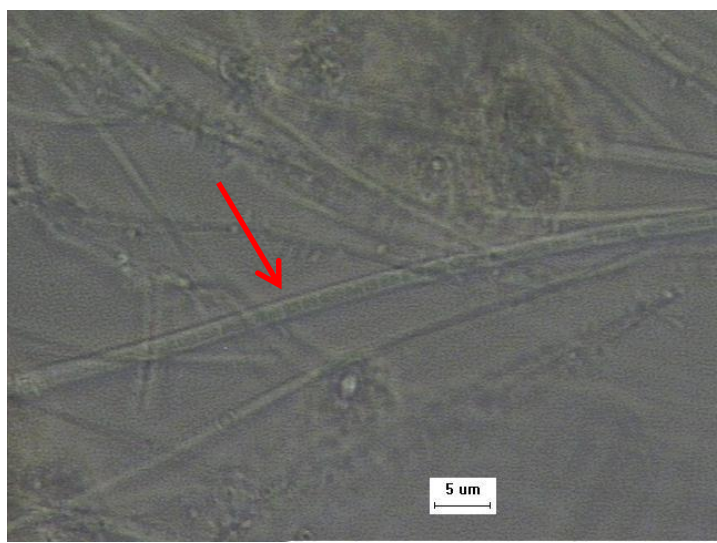

(d)

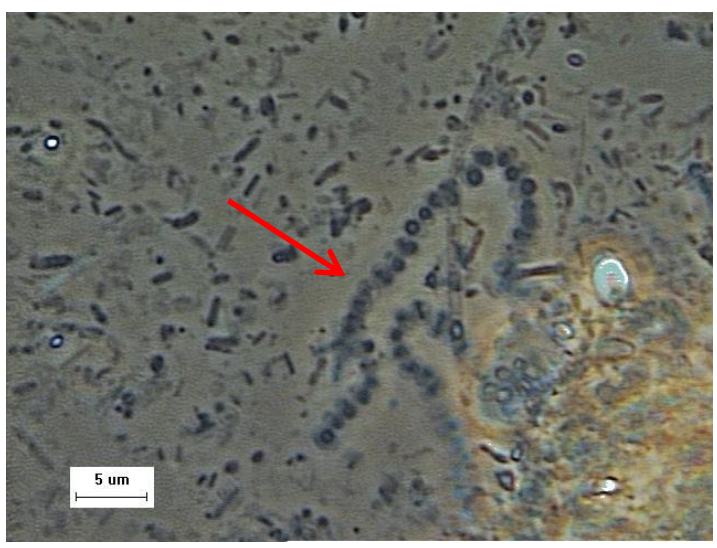

(f)

Figura 5-38. Microscopia óptica comum da biomassa de lodos ativados utilizado para inoculação nos reatores DT0 e DT2. (a) morfologia semelhante a Euglypha nos reatores DT0, (b) ovos de rotíferos nos reatores DT0, (c) morfologia semelhante a fungo filamentoso na amostra DT0, (d) morfologia semelhante a fungo filamentoso septado na amostra DT0, (e) morfologia semelhante a fungo filamentoso na amostra DT2, (e) cocos (estreptococos) na amostra DT2.

$\mathrm{Na}$ caracterização morfológica dos reatores controle desnitrificante no tempo inicial (CDT0) e final (CDT2) (Figura 5-39) foi possível verificar predomínio de fungos, filamentosas e bacilos. A partir da presença desses organismos, tanto na amostra DT0, quanto DT2 pode-se confirmar os dados de consumo de DQO e a produção de ácidos orgânicos no reator inoculado com biomassa inativada. 


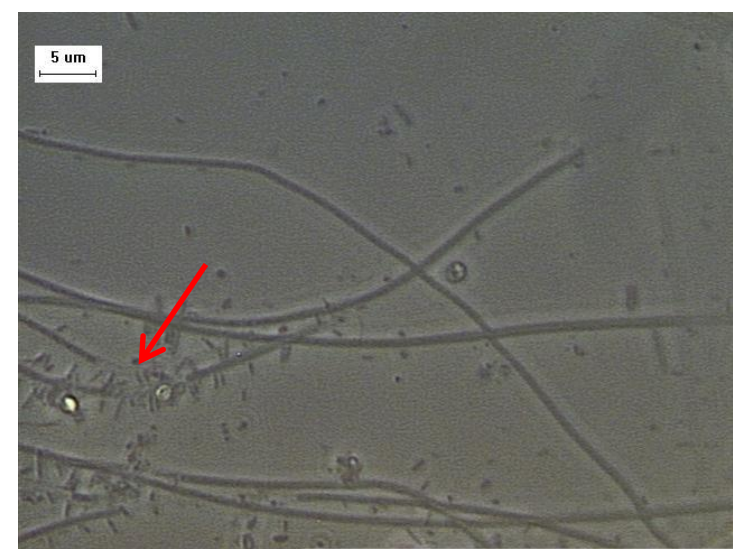

(a)

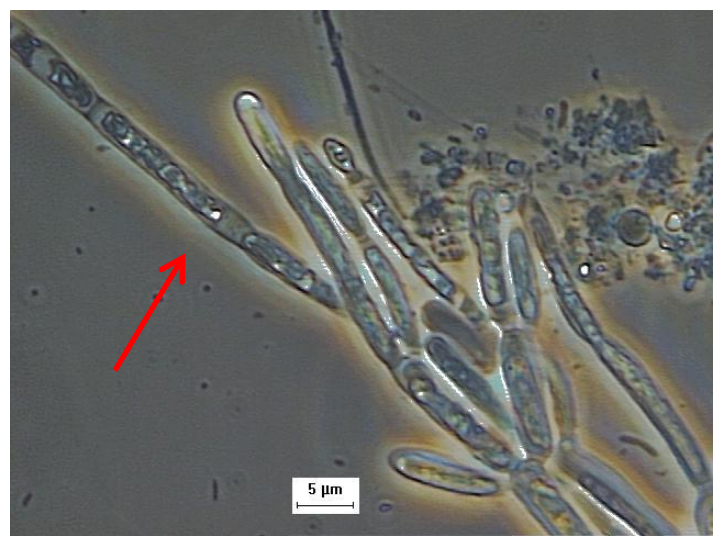

(c)

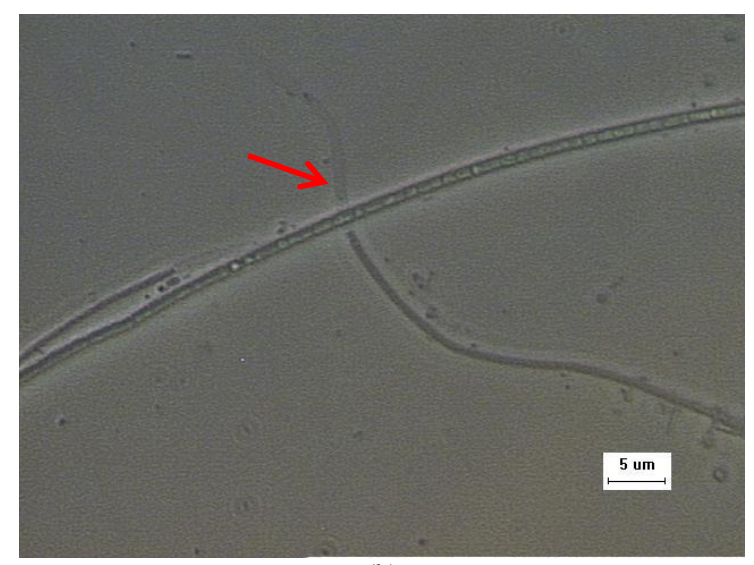

(b)

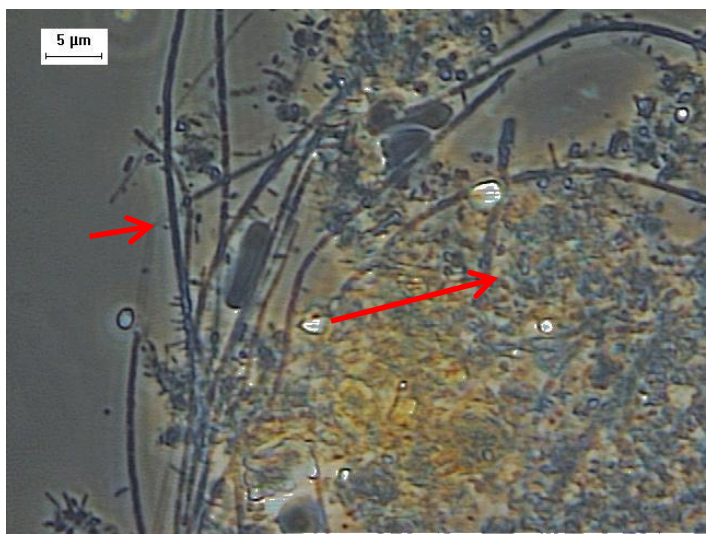

(d)

Figura 5-39. Microscopia óptica comum da biomassa inativada por meio de tratamento térmico da biomassa anóxica proveniente dos reatores controle desnitrificante (CDT0 e CDT2). (a) e (b) filamentosas no reator DT0, (c) fungos no reator DT2, (d) filamentosas e bacilos no reator DT2.

\subsubsection{Caracterização microbiana}

Por meio da análise de DGGE e do perfil de bandas para o Domínio Bacteria foram comparadas amostras provenientes do reator controle (CD) e desnitrificante (D) no tempo inicial (CDT0 e DT0), no meio da operação (CDT1 e DT1) e no final da operação (CDT2 e DT2) (Figura 5-40). Observou-se maior variação dos coeficientes de similaridade entre os reatores desnitrificante e controle $(42 \%$ de similaridade), sendo possível distinguir dois grupos bem distintos, reatores inoculados com a biomassa ativa (D) e os reatores inoculados com a biomassa inativada (CD). Esta variação foi devido principalmente ao baixo índice de similaridade das populações desnitrificantes após o tratamento térmico do inóculo. Esse resultado era esperado, porque a inativação por meio de tratamento térmico afetou diretamente as bactérias desnitrificantes, visto que nos reatores controles não houve consumo de nitrato. 

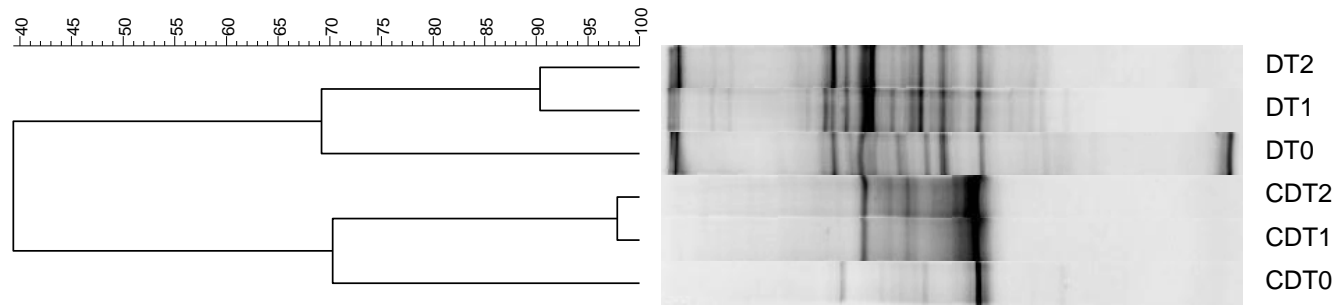

Figura 5-40 Análise de cluster (Correlação de Pearson) do perfil de bandas do PCR/DGGE dos fragmentos RNAr 16S para o Domínio Bacteria para as amostras reatores desnitrificante no início (DT0), no meio (DT1) e final da operação (DT2), bem como para os reatores controle no início (CDT0), no meio (CDT1) e final da operação (CDT2).

Ao longo da operação dos reatores verificou-se diminuição do índice de diversidade ShannonWienner (H') por meio do PCR/DGGE (Tabela 5-36) para as populações dos reatores controle e desnitrificante. Observou-se índice de diversidade de 3,17, 3,02 e 2,64, para DT0, DT1 e DT2, respectivamente. Ademais, verificou-se índice de similaridade de 3,06, 2,30 e 2,20 para CDT0, CDT1 e CDT2, respectivamente.

Assim, constatou-se os menores valores para as amostras do tempo final (2,64 e 2,20, para DT2 e CDT2, respectivamente). A partir desse resultado, pode-se inferir que ocorreu seleção das populações nos reatores, e apenas aquelas resistentes ao PCB continuaram no sistema.

Verificou-se neste estudo, maior índice de diversidade Shannon-Wienner (H') por meio do PCR/DGGE no tempo inicial de operação, DT0 $(3,17)$ em relação ao tempo final de operação do reator, DT2 $(2,64)$. Por meio do índice de diversidade Shannon-Wienner (H') a partir do sequenciamento massivo das amostras do reator desnitrificante (DT0 e DT2) observou-se que no final da operação (DT2) valores menores $(4,58)$, quando comparados com aqueles para as amostras iniciais (DT0), ou seja, de 4,78 .

Comparando-se as duas analises do índice de diversidade Shannon-Wienner $\left(\mathrm{H}^{\prime}\right)$, por meio do PCR/DGGE e por meio do sequenciamento massivo, é possível verificar menor índice de diversidade nas amostras de DT2 em ambas as análises. Por meio desses resultados pode-se destacar que houve seleção de microrganismos resistentes ao PCB e, consequentemente, diminuição da diversidade microbiana.

Tabela 5-36 Índice de Shannon-Wienner $\left(\mathrm{H}^{\prime}\right)$ para as amostras dos reatores desnitrificante do Ensaio de Remoção de PCB

\begin{tabular}{cccc|ccc} 
& \multicolumn{3}{c|}{ Reator Desnitrificante (D) } & \multicolumn{3}{c}{ Reator Controle (CD) } \\
& DT0 & DT1 & DT2 & CDT0 & CDT1 & CDT2 \\
\hline Domínio Bacteria & 3,17 & 3,02 & 2,64 & 3,06 & 2,30 & 2,20 \\
\hline
\end{tabular}




\subsection{Análise Comparativa}

Por meio do índice de dissimilaridade de Bray-Curtis (BRAY; CURTIS, 1957) calcula-se estatisticamente quanto a composição microbiana é diferente entre as amostras a partir da abundância relativa das UTOs em cada amostra e o total de sequencias em ambas as amostras. Usualmente, os valores do índice são maiores para as amostras que apresentam menores similaridades, mas para facilitar a interpretação, os valores de dissimilaridade (ID) foram convertidos em similaridade (IS).

Assim, no presente estudo realizou-se a comparação entre a comunidade microbiana do inóculo e dos reatores, tanto metanogênico quanto desnitrificante, depois de 101 e 99 dias, respectivamente. Observou-se índice de similaridade de Bray-Curtis de 19\% entre as amostras MT0 (inóculo) e MT2, do reator metanogênico, e 12\% entre as amostras dos reatores DT0 (inóculo) e DT2, do reator desnitrificante (Figura 5-41).

A seleção da microbiota em reatores metanogênicos em batelada foi verificada por Gomes et al. (2014). Os autores compararam a composição microbiana entre os reatores com PCB $\left(0,7 \mathrm{mg} . \mathrm{L}^{-1}\right)$ e sem PCB depois de 60 dias, e encontraram índice de similaridade de Bray-Curtis de $42 \%$.

Comparando-se os resultados similaridade de Bray-Curtis do presente estudo (19\% entre as amostras dos reatores metanogênicos em 101 dias e $12 \%$ entre as amostras dos reatores desnitrificantes em 99 dias) e de Gomes et al. (2014) (42\% entre os reatores com PCB e sem PCB depois de 60 dias) foi possível inferir a obtenção de menores índices no presente estudo. A partir desses resultados pode-se inferir que as mudanças na estrutura da comunidade microbiana foram relacionadas com o tempo de operação dos reatores, de 101 dias e 99 dias para o presente estudo e 60 dias para de Gomes et al. (2014), bem como, em relação às características do inóculo usado no presente estudo e aquele de Gomes et al. (2014).

Allison; Martiny (2008) afirmaram que a composição da maioria dos grupos microbianos são sensíveis a perturbações, entretanto, não imediatamente resistentes, independentemente da diversidade taxonômica ou do tipo de perturbação. A partir dos resultados apresentados neste trabalho pode-se afirmar que ocorreram alterações na comunidade dos reatores, quando comparada com os respectivos inóculos, possivelmente devido a respostas a presença de PCB nos reatores. 


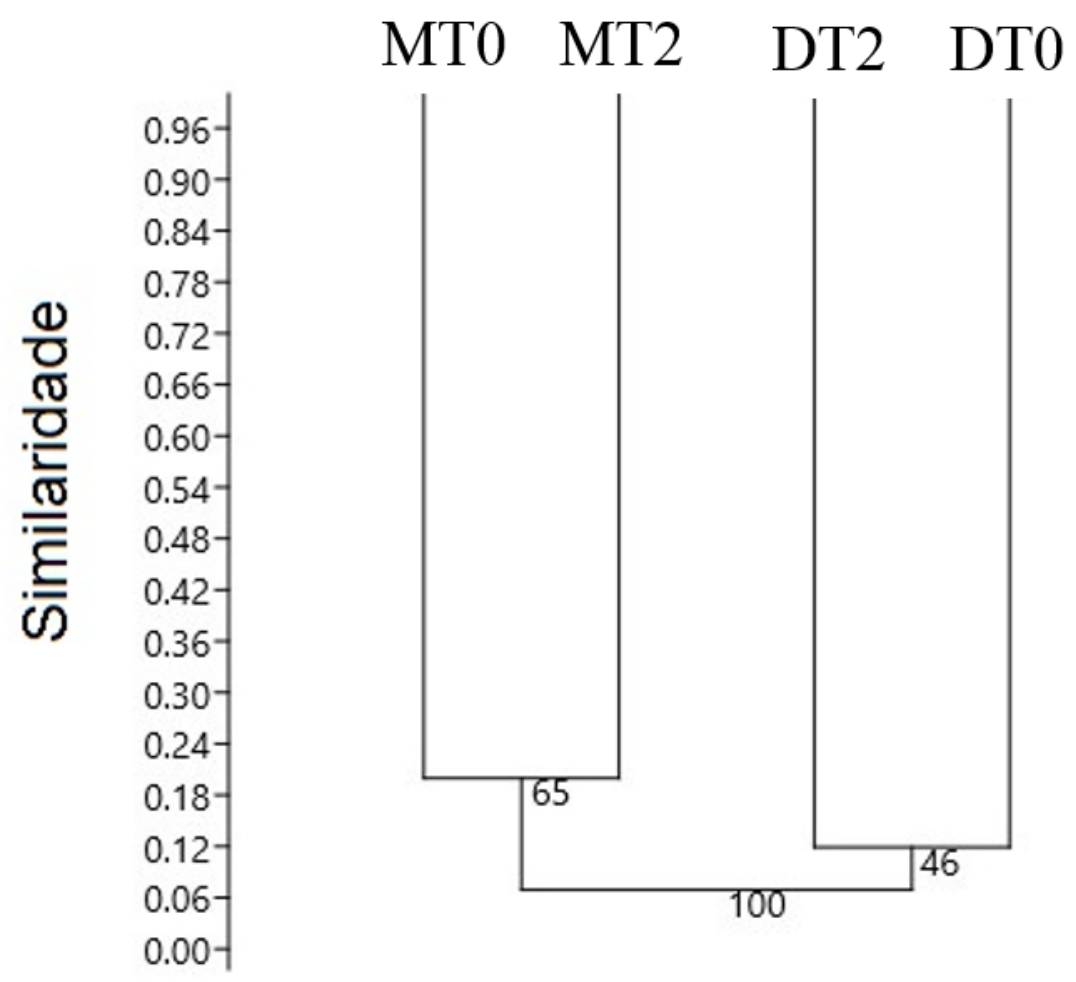

Figura 5-41 Dendograma da análise de agrupamento das amostras dos reatores MT0, MT2, DT0 e DT2. Índice de similaridade calculado através do índice de dissimilaridade de Bray-Curtis e agrupamento UPGMA.

Observou-se 4.611 OTUS com no mínimo duas sequencias (doubletons) para Domínio Bacteria, sendo 65.000 e 66.000 sequencias para os reatores DT2 e MT2.

Em virtude da abundância relativa dos filos classificados foram descritos e comparados os quatro grupos mais abundantes em cada amostra dos reatores metanogênico (MT2) e desnitrificante (DT2) no final da operação (Tabela 5-37 e Figura 5-42).

Tabela 5-37 Quatro grupos mais abundantes em cada amostra MT2 e DT2, relação de UTO representativa, filiação a partir do RDP classifier e abundância relativa em cada amostra.

\begin{tabular}{cccc} 
UTO & & MT2 & DT2 \\
S000005395 & Aeromonadaceae (F) & & $28,4 \%$ \\
\hline S000437409 & Lutispora (G) & $8,9 \%$ \\
\hline S001151153 & Sedimentibacter (G) & $12,26 \%$ & $8,0 \%$ \\
\hline S003322713 & Thermotogaceae (F) & $29,59 \%$ & $6,1 \%$ \\
\hline S000115171 & Anaerolinaceae (F) & $3,86 \%$ & \\
\hline S000502111 & Synergistaceae (F) & $2,98 \%$ & \\
\hline
\end{tabular}

Identificou-se dois grupos em ambas as amostras (MT2 e DT2), sendo uma UTO que se afiliou ao gênero Sedimentibacter (S001151153) e outra que se afiliou a família Thermotogaceae 
(S003322713). Ambos os grupos foram identificados em sistemas onde a degradação de PCB foi evidenciada (HOLOMAN et al., 1998; WU; SOWERS; MAY, 2000; WATTS et al., 2001; YAN; LAPARA; NOVAK, 2006). A partir desses resultados pode-se inferir que provavelmente estes microrganismos desempenharam importante papel na remoção do PCB.

Representantes da família Aeromonadaceae (S000005395) e gênero Lutispora (S000437409) foram identificados apenas nas amostras dos reatores anóxicos (DT2), enquanto, representantes das famílias Anaerolinaceae (S000115171) e Synergistaceae (S000502111) foram identificadas apenas nos reatores metanogênicos.

Neste trabalho, em ambas as condições não foram identificados grupos clássicos degradadores de PCB, como e Dehalococcoides (PIEPER; SEEGER, 2008a), entretanto a remoção do PCB foi evidente, tanto, nos reatores metanogênicos, quanto, nos anóxicos, com 81,5\% e 74,0\% de remoção média, respectivamente. Por meio destes resultados pode-se salientar a importância da heterogeneidade da comunidade microbiana no processo de remoção de tóxicos, bem como a capacidade de degradação de PCB de diferentes microrganismos. 


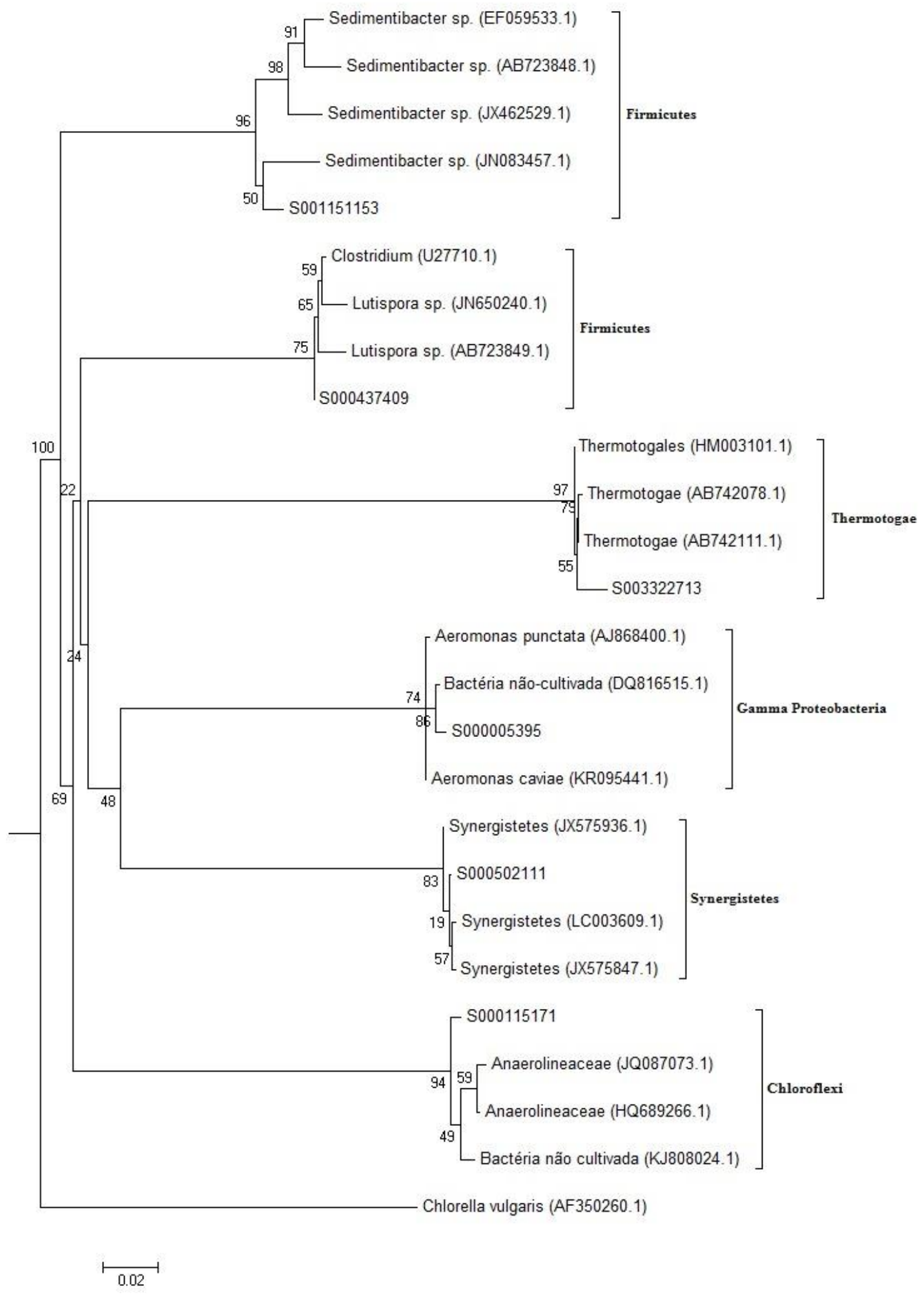

Figura 5-42 Árvore filogenética da biomassa dos reatores CD e CM construída com as quatro UTOs com maior abundancia relativa em cada amostra. A barra da escala refere-se a distância filogenética e Chlorella vulgaris foi escolhida como outgroup de 1.000 amostragens. $O$ número de acesso do GenBank está entre parênteses. 
Evidenciou-se distintas taxas de biossorção de cada congênere em cada inóculo. Para o inóculo anaeróbio, observou-se biossorção de 38,3\%, 74,3\%, 89,0\%, 48,7\% e 39,7\%, respectivamente para PCB $10,28,52,153,138$ e 180. Para o inóculo anóxico, constatou-se biossorção de 24,7\%, 11,0\%, 9,7\%, $5,0 \%, 75,3 \%$ e $87,7 \%$, respectivamente para PCB 10, 28, 52, 153, 138 e 180.

A concentração de sólidos do inóculo anaeróbio foi 48,06 g.L $\mathrm{L}^{-1}$ de STV nos reatores controle (CM), e 22,38 g.L-1 de STV nos reatores controle com inóculo anóxico (CD). Observou-se maior biossorção média na biomassa anaeróbia (de 61,1\%) em relação ao inóculo anóxico, com 35,6\% de biossorção média (Tabela 5-38).

Chang et al. (1999) demonstraram que a taxa de biossorção é diretamente proporcional a concentração de sólidos do inóculo, e maior adsorção de PCB foi encontrado no lodo com maior concentração de sólidos.

Tabela 5-38 Comparação entre a concentração biossorvida dos seis congêneres de PCB (PCB 10, 28, 52, 153,138 e 180) nos reatores controle desnitrificante $(C D)$ e metanogênico $(C M)$.

\begin{tabular}{cc|c|c|c|c|c||c} 
& PCB 10 & PCB 28 & PCB 52 & PCB 153 & PCB 138 & PCB 180 & Média \\
\hline Biossorção D ${ }^{1}$ & 0,37 & 0,17 & 0,15 & 0,08 & 1,13 & 1,32 & 0,53 \\
\hline \% biossorção D & 24,7 & 11,0 & 9,7 & 5,0 & 75,3 & 87,7 & 35,6 \\
\hline \hline Biossorção M ${ }^{2}$ & 0,58 & 1,12 & 1,18 & 1,34 & 0,73 & 0,57 & 0,92 \\
\hline \% biossorção M & 38,3 & 74,3 & 78,7 & 89,0 & 48,7 & 37,7 & 61,1 \\
\hline \multicolumn{7}{c}{ Reator Controle desnitrificante: Biomassa inativada por tratamento térmico } \\
${ }^{2}{ }^{1}$ Reator Controle metanogênico: Biomassa inativada por tratamento térmico
\end{tabular}

A concentração média removida dos PCBs totais na condição metanogênica foi de $0,40 \mathrm{mg} \cdot \mathrm{L}^{-1}$, representando remoção de $81,5 \%$, e na condição desnitrificante foi de $0,72 \mathrm{mg} . \mathrm{L}^{-1}$, o que representou remoção de $74,0 \%$, para concentração inicial de $1,5 \mathrm{mg} . \mathrm{L}^{-1}$.

Por meio da eficiência de remoção tem-se quão eficiente é o sistema, relacionando o quanto está biodisponível e o quanto é removido. Assim, na condição metanogênica verificou-se concentração final no sistema de $0,09 \mathrm{mg} \cdot \mathrm{L}^{-1}$, enquanto para os reatores desnitrificantes, a concentração final foi de 0,25 mg.L $\mathrm{L}^{-1}$. A partir desses resultados, pode-se afirmar que a maior eficiência de remoção do PCB foi encontrada sob condição anaeróbia.

Resultados similares foram encontrados por Chang et al. (1999), que avaliaram a desalogenação de PCB por meio de consórcio proveniente de lodo adaptado ao clorofenol. Estes autores evidenciaram que a taxa de remoção de cloro foi maior sob condições metanogênicas comparada com a condição desnitrificante. 


\section{Considerações Finais}

\section{Hipótese 1: O SPME é uma metodologia eficaz da avaliação de PCB de amostras de reatores.}

A metodologia de extração de PCB pelo método de SPME para a identificação e quantificação de seis congêneres de PCB em reatores é eficaz e confiável.

* Hipótese aceita: Por meio da análise dos resultados verificou-se que a utilização da técnica de SPME para avaliação de PCB foi adequada. A partir da obtenção de picos cromatográficos com resolução apropriada, faixa de linearidade ampla, seletividade frente a várias possíveis substâncias interferentes e robustez, foi possível confirmar a utilidade e confiabilidade desse método na identificação e quantificação específica dos seis congêneres de PCB em reatores biológicos. Mais especificamente foi possível concluir que:

- A utilização da técnica de adição de padrão solucionou a problemática de biossorção do PCB no lodo, conferindo à técnica simplicidade na extração dos analitos, minimizando o acréscimo de solventes visando a diminuição da interferência da matriz e de erros operacionais. 


\section{Hipótese 2: A condição fermentativa-metanogênica abriga comunidade resistente a presença de PCB e capaz de removê-lo}

\section{Sub-Hipótese 2A: A presença do PCB inibe a comunidade fermentativa- metanogênica}

A adição de PCB em reatores em batelada, inoculados com lodo anaeróbio não-adaptado, proveniente de reator UASB, com etanol $\left(547 \mathrm{mg} . \mathrm{L}^{-1}\right)$ e formiato de sódio $\left(680 \mathrm{mg} . \mathrm{L}^{-1}\right)$ como cosubstratos e meio sintético (ANGELIDAKI et al., 2009) é capaz de inibir a comunidade fermentativametanogênica.

* Hipótese aceita: Por meio da análise dos resultados observou-se correlação direta entre a concentração de PCB adicionada no reator e a produção máxima de metano. Verificou-se ainda que a crescente adição de PCB em reatores fermentativosmetanogênicos inibiu o consumo de matéria orgânica e o metabolismo acidogênico, além de alterar a estrutura da comunidade microbiana nos reatores. Mais especificamente foi possível concluir que:

- Nos reatores em que foi adicionado menor concentração de PCB, apenas a comunidade metanogênica foi inibida.

- Nos reatores em que foi adicionado maiores concentrações de PCB, tanto a comunidade metanogênica quanto acidogênica foram inibidas.

- $\mathrm{O}$ valor de $\mathrm{IC}_{50}$ calculado nos reatores fermentativos-metanogênicos foi de $0,03 \mathrm{mg} \cdot \mathrm{L}^{-1}$.

\section{Sub-Hipótese 2B: A comunidade fermentativa-metanogênica é capaz de remover o PCB, e a presença do PCB altera a comunidade microbiana.}

$\mathrm{O}$ PCB é removido em reatores em batelada inoculados com lodo anaeróbio não-adaptado proveniente de reator UASB, com etanol $\left(547 \mathrm{mg} . \mathrm{L}^{-1}\right)$ e formiato de sódio $\left(680 \mathrm{mg} . \mathrm{L}^{-1}\right)$ como cosubstratos e meio sintético (ANGELIDAKI et al., 2009). Ademais, observou-se alteração na comunidade microbiana no final da operação dos reatores em batelada.

* Hipótese aceita: Por meio da análise dos resultados observou-se que os seis congêneres de PCB adicionados nos reatores foram removidos. Mais especificamente foi possível concluir que:

- Evidenciou-se remoção média de PCBs totais de $0,40 \mathrm{mg} \cdot \mathrm{L}^{-1}$, representando taxa de remoção de $81,5 \%$.

- Por meio da análise dos índices ecológicos confirmou-se para a amostra do reator no tempo inicial (MT0) maior riqueza, dominância, diversidade e equitabilidade comparada com amostra do reator no tempo final (MT2), tanto para o Domínio Bacteria quanto para o Archaea.

- Por meio do sequenciamento massivo do gene RNAr 16S, notou-se alteração das populações do inóculo, quando comparadas com aquelas no final do experimento. 138 
- Por meio do sequenciamento massivo do gene RNAr 16S, notou-se enriquecimento de quatro grupos (Thermotogaceae, Sedimentibacter, Anaerolinaceae e Pseudomonas) apenas na amostra no final do experimento.

\section{Hipótese 3: A condição desnitrificante abriga comunidade resistente a presença de PCB e capaz de removê-lo.}

\section{Sub-Hipótese 3A: A relação $\mathrm{C} / \mathrm{N}-\mathrm{NO}_{3}{ }^{-}$para a comunidade desnitrificante é especifica na presença do PCB.}

A relação ideal $\mathrm{C} / \mathrm{N}^{-\mathrm{NO}_{3}}{ }^{-}$para a comunidade desnitrificante em reatores em batelada inoculados com lodo não-daptado proveniente de lodos ativados, com etanol $\left(598,9 \mathrm{mg} . \mathrm{L}^{-1}\right)$ como co-substrato, meio sintético (ANGELIDAKI et al., 2009) e nitrato de sódio (de 93,0 mg.L.-1 a 7.150,0 mg.L.-1 de $\mathrm{NO}_{3}$ ) é específica na presença de PCB $\left(1,5 \mathrm{mg} \cdot \mathrm{L}^{-1}\right)$.

Hipótese aceita: Por meio da análise dos resultados observou-se que a relação ideal $\mathrm{C} / \mathrm{N}-\mathrm{NO}_{3}{ }^{-}$para a comunidade desnitrificante em reatores em batelada é especifica na presença de PCB. Mais especificamente foi possível concluir que:

- Na presença de PCB, a desnitrificação ocorreu, uma vez que em todos os reatores com diferentes concentrações de nitrato, houve consumo desta fonte de nitrogênio.

- Ademais, a relação ideal estabelecida para $\mathrm{C} / \mathrm{N}^{-} \mathrm{NO}_{3}{ }^{-}$na presença de $\mathrm{PCB}$ foi 6,95 .

\section{Sub-Hipótese 3B: A concentração de PCB inibe a comunidade desnitrificante.}

A adição de PCB em reatores em batelada, inoculados com lodos ativados não-adaptado, etanol (589,9 mg. $\mathrm{L}^{-1}$ ) como co-substrato, meio sintético (ANGELIDAKI et al., 2009) e nitrato de sódio (de $665,78 \mathrm{mg} . \mathrm{L}^{-1}$ a $2.434,94 \mathrm{mg} . \mathrm{L}^{-1}$ de $\mathrm{NO}_{3}$ ) é capaz de inibir a comunidade desnitrificante.

* Hipótese aceita: Por meio da análise dos resultados observou-se que existe correlação direta entre a concentração de PCB e a inibição desnitrificante. Mais especificamente foi possível concluir que:

- O valor de $\mathrm{IC}_{50}$ calculado nos reatores desnitrificantes foi de $1,0 \mathrm{mg} \cdot \mathrm{L}^{-1}$.

\section{Sub-Hipótese 3C: Sob condição desnitrificante o PCB é removido e a presença do tóxico afeta a composição da comunidade microbiana.}

O PCB é removido em reatores em batelada inoculados com lodos ativados não-adaptado, etanol (589,9 mg.. $\mathrm{L}^{-1}$ ) como co-substrato, meio sintético (ANGELIDAKI et al., 2009) e nitrato de sódio 
(1.652,2 mg.L $\mathrm{L}^{-1}$ de $\mathrm{NO}_{3}$ ). Ademais, observou-se alteração na comunidade microbiana no final da operação dos reatores em batelada.

* Hipótese aceita: Por meio da análise dos resultados observou-se que os seis congêneres de PCB adicionados nos reatores foram removidos. Mais especificamente foi possível concluir que:

- Evidenciou-se remoção média de PCBs totais de $0,72 \mathrm{mg} . \mathrm{L}^{-1}$, representando taxa de remoção de $74,0 \%$.

- Por meio da análise dos índices ecológicos confirmou-se para a amostra do reator no tempo inicial (DT0) maior diversidade e equitabilidade comparada com amostra do reator no tempo final (DT2) para o Domínio Bacteria.

- Por meio do sequenciamento massivo do gene RNAr 16S, notou-se alteração da das populações do inóculo quando comparadas com aquelas do final do experimento.

- Por meio do sequenciamento massivo do gene RNAr 16S, notou-se o enriquecimento de quatro grupos (Aeromonadaceae, Lutispora, Sedimentibacter e Thermotogaceae) apenas na amostra no final do experimento.

\section{Hipótese 4: A remoção de PCB e a composição microbiana foi distinta em cada condição.}

A remoção de PCB em reatores em batelada inoculados com lodos ativados não-adaptado, etanol (589,9 mg.L $\mathrm{L}^{-1}$ ) como co-substrato, meio sintético (ANGELIDAKI et al., 2009) e nitrato de sódio (1.652,2 mg. $\mathrm{L}^{-1}$ de $\mathrm{NO}_{3}$ ) e em reatores em batelada inoculados com lodo anaeróbio não-adaptado proveniente de reator UASB, com etanol $\left(547 \mathrm{mg} . \mathrm{L}^{-1}\right)$ e formiato de sódio (680 mg.L $\left.\mathrm{L}^{-1}\right)$ como cosubstratos e meio sintético (ANGELIDAKI et al., 2009) foi distinta. Ademais, observou-se diferentes populações microbianas em cada reator no final da operação.

* Hipótese aceita: Por meio da análise dos resultados observou-se maior eficiência de remoção do PCB para a condição anaeróbia quando comparada com a condição anóxica. Mais especificamente foi possível concluir que:

- Evidenciou-se taxa de remoção de PCBs totais de $81,5 \%$ e $74,0 \%$, respectivamente para condição anaeróbia e anóxica.

- Por meio da análise de similaridade de Bray-Curtis confirma-se que houve alteração na composição microbiana nos reatores e obteve-se valores de similaridade de $19 \%$ e $12 \%$, entre MT0 e MT2 e entre DT0 e DT2, respectivamente.

- Por meio do sequenciamento massivo do gene RNAr 16S, notou-se o enriquecimento de dois grupos (Sedimentibacter e Thermotogaceae) em ambos os reatores no final do experimento.

- $\quad$ Entretanto, mesmo verificando-se elevada abundancia relativa de dois grupos nas amostras DT2 e MT2, evidenciou-se diferença significativa entre as biomassas em cada condição. 


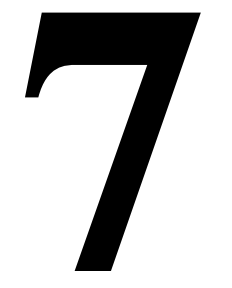

\section{Conclusões}

* Verificou-se a eficácia da metodologia de extração de PCB pelo método de SPME para a identificação e quantificação de seis congêneres de PCB.

* O PCB inibiu a comunidade fermentativa-metanogênica em reatores em batelada, inoculados com lodo anaeróbio não-adaptado.

* A remoção efetiva de PCB nos ensaios em batelada inoculados com lodo anaeróbio nãoadaptado foi de $81,5 \%$.

* Notou-se enriquecimento de quatro grupos (Thermotogaceae, Sedimentibacter, Anaerolinaceae e Pseudomonas) apenas na amostra no final do Ensaio de Remoção de PCB sob condição fermentativa-metanogênica.

Observou-se, na presença de $\mathrm{PCB}$, relação ideal $\mathrm{C} / \mathrm{N}^{-\mathrm{NO}_{3}}{ }^{-}$de 6,95 .

- O PCB inibiu a comunidade desnitrificante em reatores em batelada, inoculados com lodos ativados não-adaptado.

A remoção efetiva de PCB nos ensaios em batelada inoculados com lodos ativados não-adaptado foi de $74,0 \%$. 
* Notou-se enriquecimento de quatro grupos (Aeromonadaceae, Lutispora, Sedimentibacter e Thermotogaceae) apenas na amostra no final do Ensaio de Remoção de PCB sob condição desnitrificante.

* A remoção de PCB é mais efetiva sob condição fermentativa-metanogênica.

A partir do Ensaio de Remoção de PCB, observou-se a presença de dois grupos em ambas as amostras DT2 e MT2 (Sedimentibacter e Thermotogaceae). 


\section{Referências Bibliográficas}

ABRAHAM, W. R. et al. Phylogeny and polyphasic taxonomy of Caulobacter species. Proposal of Maricaulis gen. nov. with Maricaulis maris (Poindexter) comb. nov. as the type species, and emended description of the genera Brevundimonas and Caulobacter. International journal of systematic bacteriology, v. 49 Pt 3, p. 1053-73, jul. 1999.

ABRAMOWICZ, D. A. Aerobic and Anaerobic Biodegradation of PCBs: A Review. Critical Reviews in Biotechnology, v. 10, n. 3, p. 241-251, 27 jan. 1990

ADAV, S. S.; LEE, D.-J.; LAI, J. Y. Enhanced biological denitrification of high concentration of nitrite with supplementary carbon source. Applied microbiology and biotechnology, v. 85, n. 3, p. 773-8, jan. 2010

ADORNO, M. A. T. Desenvolvimento de métodos de extração e determinação de Bifenilas Policloradas por cromatografia gasosa e detector de captura de elétrons em óleo Ascarel, reator anaeróbio e solo. [s.1.] Universidade de São Paulo, 2013.

ADORNO, M. A. T. Desenvolvimento e validação de método para determinação de nitrogênio, hidrogênio, metano e gás carbônico por CG/DCT37a. Reunião Anual da Sociedade Brasileira de Química - SBQ, em Natal, RN, Brasil. Anais...2014

ADORNO, M. A. T.; HIRASAWA, J. S.; VARESCHE, M. B. A. Development and Validation of Two Methods to Quantify Volatile Acids (C2-C6) by GC/FID: Headspace (Automatic and Manual) and Liquid-Liquid Extraction (LLE). American Journal of Analytical Chemistry, v. 05, n. 07, p. 406-414, 6 maio 2014 .

AHMED, M.; FOCHT, D. D. Oxidation of polychlorinated biphenyls by achromobacter pCB. Bulletin of environmental contamination and toxicology, v. 10, n. 2, p. 70-2, ago. 1973.

AKUNNA, J. C.; BIZEAU, C.; MOLETTA, R. Denitrification in anaerobic digesters: possibilities and influence of wastewater COD/N-NOX ratio. Environmental Technology, v. 13, n. 9, p. 825-836, 17 set. 1992

ALDER, A. C. et al. Reductive dechlorination of polychlorinated biphenyls in anaerobic sediments. Environmental Science \& Technology, v. 27, n 3, p. $530-538$, mar. 1993 .

ALLISON, S. D.; MARTINY, J. B. H. Resistance, resilience, and redundancy in microbial communities. Proceedings of the National Academy of Sciences of the United States of America, v. 105, p. 11512-11519, 2008.

ALMEIDA, C. M. M.; BOAS, L. V. Analysis of BTEX and other substituted benzenes in water using headspace SPME-GC-FID: method validation. Journal of environmental monitoring : JEM, v. 6, n. 1, p. 80-8, jan. 2004. 
ANGELIDAKI, I. et al. Defining the biomethane potential (BMP) of solid organic wastes and energy crops : a proposed protocol for batch assays. Water Science and Technology, v. 59, n. 5, p. 927-934, 2009.

ANGERER, J.; SCHALLER, K.-H. Analyses of Hazardous Substances in Biological Materials, Volume 1. Weinheim, Germany: VCH, 1985.

ANTONELLO, I. et al. Determinação de ascarel em óleo isolante de transformadores. Química Nova, v. 30, n. 3, p. 709-711, jun. 2007. DC: [s.n.].

APHA AMERICAN PUBLIC HEALTH ASSOCIATION. Standard methods for the examination of water and wastewater. 21. ed. Washington,

ARNDT, D. et al. METAGENassist: a comprehensive web server for comparative metagenomics. Nucleic acids research, v. 40, n. Web Server issue, p. W88-95, 29 jul. 2012

ARTHUR, C. L.; PAWLISZYN, J. Solid phase microextraction with thermal desorption using fused silica optical fibers. Analytical Chemistry, v. 62, n. 19, p. 2145-2148, out. 1990.

ASANTE, K. A. et al. Human exposure to PCBs, PBDEs and HBCDs in Ghana: Temporal variation, sources of exposure and estimation of daily intakes by infants. Environment international, v. 37, n. 5, p. 921-8, jul. 2011.

ASTURIAS, J. A.; TIMMIS, K. N. Three different 2,3-dihydroxybiphenyl-1,2-dioxygenase genes in the gram-positive polychlorobiphenyl-degrading bacterium Rhodococcus globerulus P6. J. Bacteriol., v. 175, n. 15, p. 4631-4640, 1 ago. 1993.

ATSDR AGENCY FOR TOXIC SUBSTANCES AND DISEASE REGISTRY. Toxicological profile for Polychlorinated Biphenyls (PCBs). Atlanta, GA: U.S. Department of Health and Human Services, Public Health Service: [s.n.]. Disponível em: 〈http://www.atsdr.cdc.gov/toxprofiles/tp17.pdf〉. Acesso em: 20 jan. 2015

ATUANYA, E. I.; AIGBIRIOR, M. Mesophilic biomethanation and treatment of poultry waste-water using pilot scale UASB reactor. Environmental Monitoring and Assessment, v. 77, n. 2, p. 139-147, 2002.

BABA, D. et al. Anaerobic biodegradation of polychlorinated biphenyls by a microbial consortium originated from uncontaminated paddy soil. World Journal of Microbiology \& Biotechnology, v. 23, p. 1627-1636, 2007.

BAIRD, C.; CANN, M. Environmental Chemistry. 5. ed. [s.1.] W. H. Freeman, 2012.

BALK, M.; WEIJMA, J.; STAMS, A. J. M. Thermotoga lettingae sp. nov., a novel thermophilic, methanol-degrading bacterium isolated from a thermophilic anaerobic reactor. International Journal of Systematic and Evolutionary Microbiology, v. 52, n. 4, p. 1361-1368, 2002.

BARRET, M. et al. Influence of feed characteristics on the removal of micropollutants during the anaerobic digestion of contaminated sludge. Journal of hazardous materials, v. 181, n. 1-3, p. 241-7, 15 set. 2010

BASHEER, C. et al. Determination of organophosphorous pesticides in wastewater samples using binary-solvent liquid-phase microextraction and solid-phase microextraction: a comparative study. Analytica chimica acta, v. 605, n. 2, p. 147-52, 19 dez. 2007.

BECCARI, M. et al. Kinetcs of dissimilatory nitrate and nitrite reduction in suspended growth culture. Water Environment Federation, v. 55, n. 1, p. 58-64, 1983

BEDARD, D. L. A Case Study for Microbial Biodegradation : Anaerobic Bacterial Reductive Dechlorination of Polychlorinated Biphenyls — From Sediment to Defined Medium. n. May, 2008.

BEDARD, D. L. PCB dechlorinases revealed at last. Proceedings of the National Academy of Sciences of the United States of America, v. 111, n. 33, p. 11919-20, 19 ago. 2014.

BEER, M. et al. Phylogeny of the filamentous bacterium Eikelboom Type 1851, and design and application of a 16S rRNA targeted oligonucleotide probe for its fluorescence in situ identification in activated sludge. FEMS microbiology letters, v. 207, n. 2, p. 179-83, 5 fev. 2002

BERNET, N.; DELGENES, N.; MOLETTA, R. Denitrification by Anaerobic Sludge in Piggery Wastewater. Environmental Technology, v. 17, n. 3, p. 293-300, 11 mar. 1996.

BERTIN, L. et al. Biotransformation of a highly chlorinated PCB mixture in an activated sludge collected from a Membrane Biological Reactor (MBR) subjected to anaerobic digestion. Journal of hazardous materials, v. 186, n. 2-3, p. 2060-7, 28 fev. 2011.

BHANDARI, V.; GUPTA, R. S. Molecular signatures for the phylum (class) Thermotogae and a proposal for its division into three orders (Thermotogales, Kosmotogales ord. Nov. and Petrotogales ord. Nov.) containing four families (Thermotogaceae, Fervidobacteriaceae fam. Nov., Kosmotoga. Antonie van Leeuwenhoek, International Journal of General and Molecular Microbiology, v. 105, n. 1, p. 143-168, 2014.

BJORNSSON, L. et al. Filamentous Chloroflexi (green non-sulfur bacteria) are abundant in wastewater treatment processes with biological nutrient removal. Microbiology, v. 148, n. 8, p. 2309-2318, 1 ago. 2002.

BOONE, D. R. et al. ECOLOGY AND MICROBIOLOGY OF BIOGASIFICATION. Biomass and Bioenergy, v. 5, n. 3, p. $191-202,1993$. 
BOONE, D. R. et al. Bergey's Manual of Systematic Bacteriology Volume 2: The Proteobacteria. 2nd. ed. [s.l: s.n.].

1986

BOPP, L. H. Degradation of highly chlorinated PCBs byPseudomonas strain LB400. Journal of Industrial Microbiology, v. 1, n. 1, p. 23-29, mar.

BORJA, J. et al. Polychlorinated biphenyls and their biodegradation. Process Biochemistry, v. 40, n. 6, p. 1999-2013, maio 2005.

BOSSERT, I. D.; HÄGGBLOM, M. A X. M.; YOUNG, L. Y. CHAPTER 2: Microbial ecology of dehalogenation. Dehalogenation: Microbial processes and environmental applications, p. 33-52, 2003.

BOYLE, A. W. et al. Bacterial PCB biodegradation. Biodegradation, v. 3, n. 2-3, p. 285-298, 1992.

BOYLE, A. W. et al. Effects of Polychlorinated Biphenyl Congener Concentration and Sediment Supplementation on Rates of Methanogenesis and 2,3,6-Trichlorobiphenyl Dechlorination in an Anaerobic Enrichment. Appl. Envir. Microbiol., v. 59, n. 9, p. 3027-3031, 1 set. 1993. $349,1957$.

BRAY, J. R.; CURTIS, J. T. An Ordination of the Upland Forest Communities of Southern Wisconsin. Ecological Monographs, v. 27, n. 4, p. 325-

BREIVIK, K. et al. Towards a global historical emission inventory for selected PCB congeners - a mass balance approach1. Global production and consumption. The Science of The Total Environment, v. 290, n. 1-3, p. 181-198, 6 maio 2002

BRIÉE, C.; MOREIRA, D.; LÓPEZ-GARCÍA, P. Archaeal and bacterial community composition of sediment and plankton from a suboxic freshwater pond. Research in Microbiology, v. 158, n. 3, p. 213-227, abr. 2007.

BRIONES, A. M. et al. Characterization of microbial trophic structures of two anaerobic bioreactors processing sulfate-rich waste streams. Water research, v. 43, n. 18 , p. 4451-60, out. 2009

BROWN JR, J. F. et al. ENVIRONMENTAL DECHLORTNATION OF PCBs. Environmental Toxicology and Chemistry, v. 6, p. 579-593, 1987.

CAINES, J. Diversity of dechlorinating bacteria. In: Dehalogenation: Microbial Processes and Environmental Applications. [s.1.] Kluer Academic Publishers, 2003. p. 53-87.

CALLI, B. et al. Community changes during start-up in methanogenic bioreactors exposed to increasing levels of ammonia. Environmental technology, v. 26, n. 1, p. 85-91, 2005 .

CÁMARA, B. et al. From PCBs to highly toxic metabolites by the biphenyl pathway. Environmental microbiology, v. 6, n. 8, p. 842-850, ago. 2004.

CAPORASO, J. G. et al. QIIME allows analysis of high-throughput community sequencing data. Nature methods, v. 7, n. 5, p. 335-6, maio 2010.

CASSERLY, C.; ERIJMAN, L. Molecular monitoring of microbial diversity in an UASB reactor. International Biodeterioration \& Biodegradation v. 52 , n. 1, p. $7-12$, jul. 2003 .

CETESB. Sistema Estuarino de Santos e São Vicente. p. 183, 2001

CHANG, B. V; CHOU, S. W.; YUAN, S. Y. Microbial dechlorination of polychlorinated biphenyls in anaerobic sewage sludge. Chemosphere, v. 39 , n. 1, p. 45-54, jul. 1999

CHANG, B. V; LIU, W. G.; YUAN, S. Y. Microbial dechlorination of three PCB congeners in river sediment. Chemosphere, v. 45, p. 849-856, 2001

CHASIN, A. M. et al. Validação de métodos em análises toxicológicas: uma abordagem geral. Revista Brasileira de Toxicologia, v. 11, n. 1, p. 1-6, 1998.

CHEN, M. et al. Anaerobic Biodegradation of Polychlorinated Biphenyls by Bacteria from Hudson River Sediments. ECOTOXICOLOGY AND ENVIRONMENTAL SAFETY, v. 16, p. 95-105, 1988.

CHENG, L. et al. Enrichment and dynamics of novel syntrophs in a methanogenic hexadecane-degrading culture from a Chinese oilfield. FEMS microbiology ecology, v. 83, n. 3, p. 757-66, 1 mar. 2013.

CHIU, Y.-C.; CHUNG, M.-S. Determination of optimal COD/nitrate ratio for biological denitrification. International Biodeterioration \& Biodegradation, v. 51, n. 1, p. 43-49, jan. 2003.

CHOUARI, R. et al. Novel major bacterial candidate division within a municipal anaerobic sludge digester. Applied and environmental microbiology, v. 71, n. 4, p. 2145-53, 1 abr. 2005.

CLINE, T. et al. Method for evaluating anaerobic digester performance. Bioresource technology, v. 101, n. 22, p. 8623-6, nov. 2010.

COLE, J. R. et al. Ribosomal Database Project: data and tools for high throughput rRNA analysis. Nucleic acids research, v. 42, n. Database issue, p. D633-42, jan. 2014. 
CORREA, P. A. et al. The effects of individual PCB congeners on the soil bacterial community structure and the abundance of biphenyl dioxygenase genes. Environment international, v. 36, n. 8, p. 901-6, 1 nov. 2010.

CORTAZAR, E. et al. MultiSimplex optimisation of the solid-phase microextraction-gas chromatographic-mass spectrometric determination of polycyclic aromatic hydrocarbons, polychlorinated biphenyls and phthalates from water samples. Journal of chromatography. A, v. 978, n. 1-2, p. 165-175, 29 nov. 2002.

CUTTER, L. A. et al. Identification of a microorganism that links its growth to the reductive dechlorination of 2,3,5,6-chlorobiphenyl. Environmental Microbiology, v. 3, n. 11, p. 699-709, nov. 2001.

D'ANGELO, E.; NUNEZ, A. Effect of environmental conditions on polychlorinated biphenyl transformations and bacterial communities in a river sediment. Journal of Soils and Sediments, v. 10, n. 6, p. 1186-1199, 21 abr. 2010.

DAHLE, H. et al. Evolution of temperature optimum in Thermotogaceae and the prediction of trait values of uncultured organisms. Extremophiles : life under extreme conditions, v. 15, n. 4, p. 509-16, jul. 2011.

DAUM, M. et al. Physiological and Molecular Biological Characterization of Ammonia Oxidation of the Heterotrophic Nitrifier Pseudomonas putida. Current Microbiology, v. 37, n. 4, p. 281-288, 1 out. 1998.

DELFORNO, T. P. et al. Microbial characterization and removal of anionic surfactant in an expanded granular sludge bed reactor. Bioresource Technology, v. 107, p. 103-109, 2012

DELFORNO, T. P. Degradação de surfactante aniônico em reator EGSB sob condição metanogênica e ferro redutora com água residuária de lavanderia comercial. [s.l: s.n.].

DEROUICHE, A. et al. Simultaneous analysis of polychlorinated biphenyls and organochlorine pesticides in water by headspace solid-phase microextraction with gas chromatography-tandem mass spectrometry. Journal of chromatography. A, v. 1138, n. 1-2, p. $231-43,5$ jan. 2007.

DIGNAC, M.-F. et al. Fate of wastewater organic pollution during activated sludge treatment: nature of residual organic matter. Water Research, v. 34 , n. 17 , p. 4185-4194, dez. 2000.

DOBBINS, D. C. Biodegradation of pollutants. [s.1.] Academic Press Inc., 1995. v. 1

DRTIL, M. et al. Acidobasic balances in the course of heterotrophic denitrification. Water Research, v. 29, n. 5, p. 1353-1360, maio 1995.

DUDKOVÁ, V.; DEMNEROVÁ, K.; BEDARD, D. L. Sediment-free anaerobic microbial enrichments with novel dechlorinating activity against highly chlorinated commercial PCBs. Journal of Chemical Technology \& Biotechnology, v. 87, n. 9, p. 1254-1262, 12 set. 2012.

DWORKIN, M. et al. Archaea. Bacteria: Firmicutes, Actinomycetes. In: DWORKIN, M. et al. (Eds.). . The Prokaryotes. 3. ed. [s.1.] Springer, 2006. p. 1143.

2010

EDGAR, R. C. Search and clustering orders of magnitude faster than BLAST. Bioinformatics (Oxford, England), v. 26, n. 19, p. 2460-1, 1 out.

EL-HADJ, T. B. et al. PCB and AOX removal in mesophilic and thermophilic sewage sludge digestion. Biochemical Engineering Journal, v. 36, n. 3, p. 281-287, out. 2007.

ENDO, S.; PFENNIGSDORFF, A.; GOSS, K.-U. Salting-out effect in aqueous $\mathrm{NaCl}$ solutions: trends with size and polarity of solute molecules. Environmental science \& technology, v. 46, n. 3, p. 1496-503, 7 fev. 2012.

ERICKSON, B. D.; MONDELLO, F. J. Nucleotide sequencing and transcriptional mapping of the genes encoding biphenyl dioxygenase, a multicomponent polychlorinated-biphenyl-degrading enzyme in Pseudomonas strain LB400. J. Bacteriol., v. 174, n. 9, p. $2903-2912$, 1 maio 1992.

FAGERVOLD, S. K. et al. Sequential Reductive Dechlorination of meta -Chlorinated Polychlorinated Biphenyl Congeners in Sediment Microcosms by Two Different Chloroflexi Phylotypes. v. 71, n. 12, p. 8085-8090, 2005.

FANG, H. H. P.; CHAN, O.-C. Toxicity of phenol towards anaerobic biogranules. Water Research, v. 31, n. 9, p. 2229-2242, set. 1997.

FAVA, F.; GENTILUCCI, S.; ZANAROLI, G. Anaerobic biodegradation of weathered polychlorinated biphenyls ( PCBs ) in contaminated sediments of Porto Marghera ( Venice Lagoon, Italy ). Chemosphere, v. 53, p. 101-109, 2003.

FELEKE, Z.; SAKAKIBARA, Y. A bio-electrochemical reactor coupled with adsorber for the removal of nitrate and inhibitory pesticide. Water research, v. 36, n. 12, p. 3092-102, jul. 2002.

FENNELL, D. E. et al. Dehalococcoides ethenogenes Strain 195 Reductively Dechlorinates Diverse Chlorinated Aromatic Pollutants. Environmental Science and Technology, v. 38, n. 7, p. 2075-2081, abr. 2004.

FIELD, J. A.; SIERRA-ALVAREZ, R. Microbial transformation and degradation of polychlorinated biphenyls. v. 155, 2008. 
FRAME, G. M.; COCHRAN, J. W.; BØWADT, S. S. Complete PCB congener distributions for 17 aroclor mixtures determined by 3 HRGC systems optimized for comprehensive, quantitative, congener-specific analysis. Journal of High Resolution Chromatography, v. 19, n. 12, p. 657-668, dez. 1996.

FUKUDA, M. et al. Identification of the bphA and bphB Genes of Pseudomonas sp. Strain KKS102 Involved in Degradation of Biphenyl and Polychlorinated Biphenyls. Biochemical and Biophysical Research Communications, v. 202, n. 2, p. 850-856, jul. 1994.

FURUKAWA, K. Modification of PCBs by Bacteria and Other Microorganisms. In: WAID, J. S. (Ed.). . PCBs and the environment. [s.1.] CRC Press, Inc.,Boca Raton, FL, 1986. p. 89-100.

FURUKAWA, K.; MATSUMURA, F. Microbial metabolism of polychlorinated biphenyls. Studies on the relative degradability of polychlorinated biphenyl components by Alkaligenes sp. Journal of agricultural and food chemistry, v. 24, n. 2, p. 251-6, jan. 1976.

FURUKAWA, K.; MIYAZAKI, T. Cloning of a gene cluster encoding biphenyl and chlorobiphenyl degradation in Pseudomonas pseudoalcaligenes. Journal of Bacteriology, v. 166, n. 2, p. 392-398, 1 maio 1986.

FURUKAWA, K.; SUENAGA, H.; GOTO, M. Biphenyl dioxygenases: functional versatilities and directed evolution. Journal of bacteriology, v. 186, n. 16, p. 5189-96, 15 ago. 2004.

GARCÍA-MORALES, J. L. et al. Comparison Between Acidogenic and Methanogenic Inhibition Caused by Linear Alkylbenzene-Sulfonate ( LAS ). Chemical and Biochemical Engineering Quarterly, v. 15, n. 1, p. 13-19, 2001.

GERARDI, M. H. Nitrification and Denitrification in the Activated Sludge Process. [s.1.] John Wiley \& Sons, 2003.

GHAFARI, S.; HASAN, M.; AROUA, M. K. Bio-electrochemical removal of nitrate from water and wastewater--a review. Bioresource technology, v. 99 , n. 10 , p. $3965-74$, jul. 2008.

GIOIA, R. et al. Polychlorinated biphenyls (PCBs) in Africa: a review of environmental levels. Environmental science and pollution research international, v. 21 , n. 10 , p. $6278-89$, maio 2014

GLASS, C.; SILVERSTEIN, J. Denitrification kinetics of high nitrate concentration water: $\mathrm{pH}$ effect on inhibition and nitrite accumulation. Water Research, v. 32, n. 3, p. 831-839, mar. 1998

GLASS, C.; SILVERSTEIN, J. Denitrification of high-nitrate, high-salinity wastewater. Water Research, v. 33, n. 1, p. 223-229, jan. 1999.

GOMES, B. C. et al. Analysis of a microbial community associated with polychlorinated biphenyl degradation in anaerobic batch reactors. Biodegradation, v. 25, n. 6, p. 797-810, nov. 2014.

GÓRECKI, T. Effect of Sample Volume on Quantitative Analysis by Solid-phase MicroextractionPart 1. Theoretical Considerations. The Analyst, v. 122, n. 10, p. 1079-1086, 1 jan. 1997.

GÓRECKI, T.; KHALED, A.; PAWLISZYN, J. The effect of sample volume on quantitative analysis by solid phase microextraction Part $2 . \dagger$ Experimental verification. The Analyst, v. 123, n. 12, p. 2819-2824, 1 jan. 1998.

GRIFFITHS, R. I. et al. Rapid Method for Coextraction of DNA and RNA from Natural Environments for Analysis of Ribosomal DNA- and rRNABased Microbial Community Composition. Applied and environmental microbiology, v. 66, n. 12, p. 5488-5491, 2000.

GRISHEHENKOV, V. G.; SLEPEN'KIN, A. V.; BORONIN, A. M. Anaerobic degradation of biphenyl by the facultative anaerobic strain Citrobacter freundii BS2211. Applied Biochemistry and Microbiology, v. 38, n. 2, p. 125-128, 2002. 60, abr. 2010

GROSTERN, A. et al. Chloroform respiration to dichloromethane by a Dehalobacter population. Environmental microbiology, v. 12, n. 4, p. 1053-

GROSTERN, A.; EDWARDS, E. A. Characterization of a Dehalobacter coculture that dechlorinates 1,2-dichloroethane to ethene and identification of the putative reductive dehalogenase gene. Applied and environmental microbiology, v. 75, n. 9, p. 2684-93, 1 maio 2009.

GUSMÃO, V. R. DE. Caracterização Microbiológica de Cultura Desnitrificante de Reator Anaeróbio Horizontal de Leito Fixo Utilizado na Remoção de BTEX. [s.l.] Universidade de Sao Paulo, 2005.

GUSMÃO, V. R. et al. BTEX and ethanol removal in horizontal-flow anaerobic immobilized biomass reactor, under denitrifying condition. Process Biochemistry, v. 41, n. 6, p. 1391-1400, 2006

GUSMÃO, V. R. et al. Performance of a reactor containing denitrifying immobilized biomass in removing ethanol and aromatic hydrocarbons (BTEX) in a short operating period. Journal of hazardous materials, v. 139, n. 2, p. 301-9, 10 jan. 2007.

HANSEN, T. L. et al. Method for determination of methane potentials of solid organic waste. Waste management, v. 24, n. 4, p. 393-400, jan. 2004

HARDMAN, D. J.; MCELDOWNEY, S.; WAITE, S. Pollution: ecology and biotreatment. [s.1.] Longman Scientific \& Technical, 1993.

HER, J.-J.; HUANG, J.-S. Influences of carbon source and C/N ratio on nitrate/nitrite denitrification and carbon breakthrough. Bioresource Technology, v. 54, n. 1, p. 45-51, jan. 1995. 
HOFER, B.; BACKHAUS, S.; TIMMIS, K. N. The biphenyl/polychlorinated biphenyl-degradation locus (bph) of Pseudomonas sp. LB400 encodes four additional metabolic enzymes. Gene, v. 144, n. 1, p. 9-16, jun. 1994.

HOLLIGER, C.; WOHLFARTH, G.; DIEKERT, G. Reductive dechlorination in the energy metabolism of anaerobic bacteria. FEMS Microbiology Reviews, v. 22, p. 383-398, 1998.

HOLOMAN, T. R. P. et al. Characterization of a Defined 2,3,5,6-Tetrachlorobiphenyl-ortho-Dechlorinating Microbial Community by Comparative Sequence Analysis of Genes Coding for 16S rRNA. Appl. Envir. Microbiol., v. 64, n. 9, p. 3359-3367, 1 set. 1998.

HUTZINGER, O.; SAFE, S.; ZITKO, V. The Chemistry of PCB's. Cleveland: CRC Press, 1974.

INMETRO, I. N. DE M. N. E Q. I. Orientações sobre Validação de Métodos de Ensaios Químicos, DOQ-CGCRE-008. [s.l: s.n.].

ITO, T. et al. Identification of a novel acetate-utilizing bacterium belonging to Synergistes group 4 in anaerobic digester sludge. The ISME journal, v. 5 , n. 12 , p. $1844-56$, dez. 2011

IVANOV, V. Environmental Microbiology for Engineers. [s.l.] CRC Press, 2010. v. 17

JANSSEN, D. B.; OPPENTOCHT, J. E.; POELARENDS, G. J. Chapter 7 BACTERIAL GROWTH ON HALOGENATED ALIPHATIC HYDROCARBONS : GENETICS AND BIOCHEMISTRY. p. 207-226, 2003.

JERIS, J. S.; MCCARTY, P. L. The Biochemistry of Methane Fermentation Using C14 Tracers. Journal Water Pollution Control Federation, v. 37, n. 2, p. $178-192,1965$

JONES, R. D. Carbon monoxide and methane distribution and consumption in the photic zone of the Sargasso Sea. Deep Sea Research Part A. Oceanographic Research Papers, v. 38, n. 6, p. 625-635, jun. 1991

JUMAS-BILAK, E. et al. Jonquetella anthropi gen. nov., sp. nov., the first member of the candidate phylum "Synergistetes" isolated from man. International journal of systematic and evolutionary microbiology, v. 57, n. Pt 12, p. 2743-8, 1 dez. 2007.

JUMAS-BILAK, E.; ROUDIÈRE, L.; MARCHANDIN, H. Description of "Synergistetes" phyl. nov. and emended description of the phylum "Deferribacteres" and of the family Syntrophomonadaceae, phylum "Firmicutes". International journal of systematic and evolutionary microbiology, v. 59, n. Pt 5, p. 1028-35, 1 maio 2009.

KÄMPFER, P.; LODDERS, N.; FALSEN, E. Hydrotalea flava gen. nov., sp. nov., a new member of the phylum Bacteroidetes and allocation of the genera Chitinophaga, Sediminibacterium, Lacibacter, Flavihumibacter, Flavisolibacter, Niabella, Niastella, Segetibacter, Parasegetibacter, Terrimonas, Fer. International journal of systematic and evolutionary microbiology, v. 61, n. Pt 3, p. 518-23, mar. 2011.

KARANASIOS, K. A. et al. Hydrogenotrophic denitrification of potable water: a review. Journal of hazardous materials, v. 180, n. 1-3, p. 20-37, 15 ago. 2010

KAYA, D.; IMAMOGLU, I.; SANIN, F. D. Impact of PCB-118 and transformer oil toxicity on anaerobic digestion of sludge: anaerobic toxicity assay results. Chemosphere, v. 92, n. 7, p. 821-7, ago. 2013a.

KAYA, D.; IMAMOGLU, I.; SANIN, F. D. Anaerobic mesophilic digestion of waste activated sludge in the presence of $2,3^{\prime}, 4,4^{\prime}, 5$ pentachlorobiphenyl. International Biodeterioration \& Biodegradation, v. 83, p. 41-47, set. 2013b.

KEYSER, M.; BRITZ, T. J.; WITTHUHN, R. C. Fingerprinting and identification of bacteria present in UASB granules used to treat winery, brewery, distillery or peach-lye canning wastewater. South African Journal of Enology and Viticulture, v. 28, n. 1, p. 69-79, 2007.

KIM, I. S.; YOUNG, J. C.; TABAK, H. H. Kinetics of acetogenesis and methanogenesis in anaerobic reactions under toxic condictions. Water Environment Research, v. 66, n. 2, p. 119-132, 1994.

KIM, J.; RHEE, G. Population Dynamics of Polychlorinated Biphenyl-Dechlorinating Microorganisms in Contaminated Sediments. Applied and environmental microbiology, v. 63, n. 5, p. 1771-1776, 1997.

KITAGAWA, W.; KAMAGATA, Y. Genetic System of Organohalide-Respiring Bacteria. In: NOJIRI, H. et al. (Eds.). . Biodegradative Bacteria: How Bacteria Degrade, Survive, Adapt, and Evolve. Tokyo: Springer Japan, 2014. p. 43-57.

KJELlERUP, B.; PAUL, P.; GHOSH, U. Spatial distribution of PCB dechlorinating bacteria and activities in contaminated soil. ... and Environmental Soil ..., v. 2012, p. 11, 2012.

KLINDWORTH, A. et al. Evaluation of general 16S ribosomal RNA gene PCR primers for classical and next-generation sequencing-based diversity studies. Nucleic acids research, v. 41, n. 1, p. e1, 7 jan. 2013

KNOWLES, R. Denitrification. Microbiological reviews, v. 46, n. 1, p. 43-70, mar. 1982.

KO, F.-C.; BAKER, J. E. Seasonal and annual loads of hydrophobic organic contaminants from the Susquehanna River basin to the Chesapeake Bay. Marine pollution bulletin, v. 48, n. 9-10, p. 840-51, maio 2004. 
KOENIG, J.; LEE, M.; MANEFIELD, M. Aliphatic organochlorine degradation in subsurface environments. Reviews in Environmental Science and Bio/Technology, v. 14, n. 1, p. 49-71, 7 ago. 2014.

KOHNO, T.; SEI, K.; MORI, K. Characterization of type 1851 organism isolated from activated sludge samples. Water science and technology : a journal of the International Association on Water Pollution Research, v. 46, n. 1-2, p. 111-4, jan. 2002.

KOROM, S. F. Natural denitrification in the saturated zone: A review. Water Resources Research, v. 28, n. 6, p. 1657-1668, 9 jun. 1992.

KOUZUMA, A.; KATO, S.; WATANABE, K. Microbial interspecies interactions: recent findings in syntrophic consortia. FRONTIERS IN MICROBIOLOGY, v. 6, n. 477, 2015.

KOWALSKI, C. H. et al. Application of Kohonen neural network for evaluation of the contamination of Brazilian breast milk with polychlorinated biphenyls. Talanta, v. 116, p. 315-21, 15 nov. 2013.

KROCKER, E. J. et al. Anaerobic treatment process stability. Water Pollution Control Federation, v. 51, n. 4, p. 718-727, 1979.

KUDO, Y. et al. Methanogen flora of paddy soils in Japan. FEMS Microbiology Ecology, v. 23, n. 1, p. 39-48, 17 jan. 1997.

KUEVER, J.; RAINEY, F. A.; WIDDEL, F. Bergey's Manual of Systematic Bacteriology Volume 1: The Archaea and the Deeply Branching and Phototrophic Bacteria. In: GARRITY, G. (Ed.). . Bergey's Manual of Systematic Bacteriology. 2. ed. New York: Springer-Verlag New York, 2005. p. 10071010 .

KUMAR, A. Environmental contamination \& bioreclamation. [s.l.] APH Publishing, 2004.

L'HARIDON, S. et al. Thermosipho geolei sp. nov., a thermophilic bacterium isolated from a continental petroleum reservoir in Western Siberia. Int J Syst Evol Microbiol, v. 51, n. 4, p. 1327-1334, 1 jul. 2001.

LANDÍN, P. et al. Determination of tri- through heptachlorobiphenyls in water samples by SPME-GC-MS-MS: Comparison of PDMS and PDMSDVB coatings. Journal of Microcolumn Separations, v. 13, n. 7, p. 275-284, 2001.

LAROE, S. L.; FRICKER, A. D.; BEDARD, D. L. Dehalococcoides mccartyi strain JNA in pure culture extensively dechlorinates Aroclor 1260 according to polychlorinated biphenyl (PCB) dechlorination Process N. Environmental science \& technology, v. 48, n. 16, p. 9187-96, 19 ago. 2014.

LAWRENCE, J.; TOSINE, H. M. Adsorption of polychlorinated biphenyls from aqueous solutions and sewage. Environmental Science \& Technology, v. 10, n. 4, p. 381-383, 1 abr. 1976.

LEE, K.-B. et al. The hierarchical system of the "Alphaproteobacteria": description of Hyphomonadaceae fam. nov., Xanthobacteraceae fam. nov. and Erythrobacteraceae fam. nov. International journal of systematic and evolutionary microbiology, v. 55, p. 1907-1919, set. 2005.

LEIGH, M. B. et al. Biphenyl-utilizing bacteria and their functional genes in a pine root zone contaminated with polychlorinated biphenyls (PCBs). The ISME journal, v. 1, p. 134-148, 2007a.

LEIGH, M. B. et al. Biphenyl-utilizing bacteria and their functional genes in a pine root zone contaminated with polychlorinated biphenyls (PCBs). The ISME journal, v. 1, n. 2, p. 134-48, 24 jun. 2007b.

LEISTER, D. L.; BAKER, J. E. Atmospheric deposition of organic contaminants to the chesapeake bay. Atmospheric Environment, v. 28, n. 8, p. 1499-1520, maio 1994.

LI, A. et al. A pyrosequencing-based metagenomic study of methane-producing microbial community in solid-state biogas reactor. Biotechnology for biofuels, v. 6, n. 1, p. 3, 1 jan. 2013a.

LI, C. et al. Pilot-scale study on nitrogen and aromatic compounds removal in printing and dyeing wastewater by reinforced hydrolysis-denitrification coupling process and its microbial community analysis. Environmental science and pollution research international, v. 22, n. 12, p. 9483-93, jun. 2015.

LI, Z. et al. Long-term anaerobic mineralization of pentachlorophenol in a continuous-flow system using only lactate as an external nutrient. Environmental science $\&$ technology, v. 47, n. 3, p. 1534-41, 5 fev. 2013b.

LIANG, Y. et al. Potential for Polychlorinated Biphenyl Biodegradation in Sediments from Indiana Harbor and Ship Canal. International biodeterioration \& biodegradation, v. 89, p. 50-57, 1 abr. 2014.

LIANG, Y. et al. Microbial community analysis of switchgrass planted and unplanted soil microcosms displaying PCB dechlorination. Applied microbiology and biotechnology, 31 mar. 2015.

LIAO, P.-C.; HUANG, B.-H.; HUANG, S. Microbial community composition of the Danshui river estuary of Northern Taiwan and the practicality of the phylogenetic method in microbial barcoding. Microbial ecology, v. 54, n. 3, p. 497-507, out. 2007.

LIGIERO, C. B. P. et al. Comparação entre métodos de quantificação em cromatografia gasosa: um experimento para cursos de química. Quimica Nova, v. 32, n. 5, p. 1338-1341, 2009. 
LLOMPART, M.; LI, K.; FINGAS, M. Solid-phase microextraction and headspace solid-phase microextraction for the determination of polychlorinated biphenyls in water samples. Analytical chemistry, v. 70, n. 13, p. 2510-5, 1 jul. 1998.

LÖFFLER, F. E. et al. Dehalococcoides mccartyi gen. nov., sp. nov., obligately organohalide-respiring anaerobic bacteria relevant to halogen cycling and bioremediation, belong to a novel bacterial class, Dehalococcoidia classis nov., order Dehalococcoidales ord. nov. and famil. International journal of systematic and evolutionary microbiology, v. 63, n. Pt 2, p. 625-35, 1 fev. 2013.

MADSEN, T.; AAMAND, H. Anaerobic transformation and toxicity of trichlorophenols in a stable enrichment culture. Appl. Envir. Microbiol., v. 58, n. 2, p. 557-561, 1 fev. 1992.

MAPHOSA, F. et al. Metagenome analysis reveals yet unexplored reductive dechlorinating potential of Dehalobacter sp. E1 growing in co-culture with Sedimentibacter sp. Environmental microbiology reports, v. 4, n. 6, p. 604-16, dez. 2012.

MARTÍNEZ-GUTIÉRREZ, E. et al. Effect of phenol and acetate addition on 2-chlorophenol consumption by a denitrifying sludge. Environmental Technology, v. 33, n. November 2014, p. 1375-1382, 2012.

MARTÍNEZ-HERNÁNDEZ, S. et al. Acetate enhances the specific consumption rate of toluene under denitrifying conditions. Archives of environmental contamination and toxicology, v. 57, n. 4, p. 679-87, nov. 2009.

MASAI, E. et al. Characterization of biphenyl catabolic genes of gram-positive polychlorinated biphenyl degrader Rhodococcus sp. strain RHA1. Appl. Envir. Microbiol., v. 61, n. 6, p. 2079-2085, 1 jun. 1995.

MAY, H. D. et al. Stimulatory and Inhibitory Effects of Organohalides on the Dehalogenating Activities of PCB-Dechlorinating Bacterium o -17. Environmental Science \& Technology, v. 40, n. 18, p. 5704-5709, set. 2006.

MAYMO-GATELL, X. et al. Isolation of a Bacterium That Reductively Dechlorinates Tetrachloroethene to Ethene. Science, v. 276, n. 5318, p. 15681571,6 jun. 1997

MERCIER, A. et al. Evaluation of three activated carbons for combined adsorption and biodegradation of PCBs in aquatic sediment. Water research, v. 59, p. 304-15, 1 ago. 2014.

MILLER, J. C.; MILLER, J. N. Statistics for analytical chemistry, 2nd edition. 1 jan. 1988.

MILLER, J. C.; MILLER, J. N. Statistics for Analytical Chemistry. 3. ed. New York: Ellis Horwood PTR Prentice Hall, 1993.

MIRANDA-TELLO, E. et al. Petrotoga halophila sp. nov., a thermophilic, moderately halophilic, fermentative bacterium isolated from an offshore oil well in Congo. International journal of systematic and evolutionary microbiology, v. 57, n. Pt 1, p. 40-4, 1 jan. 2007.

MONTEITH, H.; BRIDLE, T.; SUTTON, P. Industrial waste carbon sources for biological denitrification. [s.l: s.n.]. v. 12

MOORE, R. L.; WEINER, R. M.; GEBERS, R. Notes: Genus Hyphomonas Pongratz 1957 nom. rev. emend., Hyphomonas polymorpha Pongratz 1957 nom. rev. emend., and Hyphomonas neptunium (Leifson 1964) comb. nov. emend. (Hyphomicrobium neptunium). International Journal of Systematic Bacteriology, v. 34, n. 1, p. 71-73, 1 jan. 1984.

MUYZER, G.; WAAL, E. C. D. E.; UITIERLINDEN, A. G. Profiling of Complex Microbial Populations by Denaturing Gradient Gel Electrophoresis Analysis of Polymerase Chain Reaction-Amplified Genes Coding for 16S rRNA. Applied and environmental microbiology, v. 59, n. 3, p. 695-700, 1993.

NESB $\varnothing$, C. L. et al. Mesotoga prima gen. nov., sp. nov., the first described mesophilic species of the Thermotogales. Extremophiles : life under extreme conditions, v. 16, n. 3, p. 387-93, maio 2012. 310,2005

NOLLET, H. et al. Carbon / electron source dependence of polychlorinated biphenyl dechlorination pathways for anaerobic granules. v. 58, p. 299-

NÜBEL, U. et al. Sequence heterogeneities of genes encoding 16S rRNAs in Paenibacillus polymyxa detected by temperature gradient gel electrophoresis. Journal of bacteriology, v. 178, n. 19, p. 5636-43, out. 1996.

OCHOA-HERRERA, V. et al. Toxicity of fluoride to microorganisms in biological wastewater treatment systems. Water research, v. 43, n. 13, p. 3177-86, jul. 2009.

OEFJORD, G. D.; PUHAKKA, J. A.; FERGUSON, J. F. Reductive dechlorination of aroclor 1254 by marine sediment cultures. Environmental science \& technology, v. 28, n. 13, p. 2286-94, 1 dez. 1994.

OHMORI, T. et al. Utilization of Polyphenyl and Polyphenyl-related Compounds by Microorganisms. Part I. Agricultural and Biological Chemistry, v. 37 , n. 7, p. $1599-1605,27$ nov. 1973.

OKADA, D. Y. Degradação de surfactante aniônico em reator UASB com água residuária de lavanderia. [s.l.] Escola de Engenharia de São Carlos - USP, 2012.

2010

OLIVEIRA, L. L. D. E. Remoção de Alquilbenzeno Linear Sulfonado ( LAS ) e Caracterização Microbiana em Reator Anaeróbio de Leito Fluidificado. 
OUYANG, G.; PAWLISZYN, J. A critical review in calibration methods for solid-phase microextraction. Analytica chimica acta, v. 627, n. 2, p. 184-97, 10 out. 2008

OWEN, W. F. et al. BIOASSAY FOR MONITORING BIOCHEMICAL METHANE POTENTIAL AND ANAEROBIC TOXICITY. Water research, v. 13, n. 5, p. 485-492, 1979 .

PATUREAU, D.; TRABLY, E. Impact of anaerobic and aerobic processes on polychlorobiphenyl removal in contaminated sewage sludge. Biodegradation, v. 17, n. 1, p. 9-17, fev. 2006.

PAYNE, R. B. et al. Remediation of polychlorinated biphenyl impacted sediment by concurrent bioaugmentation with anaerobic halorespiring and aerobic degrading bacteria. Environmental science \& technology, v. 47, n. 8, p. 3807-15, 16 abr. 2013.

PAYNE, R. B.; MAY, H. D.; SOWERS, K. R. Enhanced reductive dechlorination of polychlorinated biphenyl impacted sediment by bioaugmentation with a dehalorespiring bacterium. Environmental science $\boldsymbol{\&}$ technology, v. 45 , n. 20 , p. $8772-9,15$ out. 2011

PELLETIER, E. et al. "Candidatus Cloacamonas acidaminovorans": genome sequence reconstruction provides a first glimpse of a new bacterial division. Journal of bacteriology, v. 190, n. 7, p. 2572-9, 1 abr. 2008.

PENG, X. et al. $16 \mathrm{~S}$ ribosomal DNA clone libraries to reveal bacterial diversity in anaerobic reactor-degraded tetrabromobisphenol A. Bioresource technology, v. 112, p. 75-82, maio 2012.

PENG, Y.-Z.; MA, Y.; WANG, S.-Y. Denitrification potential enhancement by addition of external carbon sources in a pre-denitrification process. Journal of environmental sciences (China), v. 19, n. 3, p. 284-9, jan. 2007

PENTEADO, E. D. et al. Influence of seed sludge and pretreatment method on hydrogen production in packed-bed anaerobic reactors. International Journal of Hydrogen Energy, v. 38, n. 14, p. 6137-6145, 2013.

PENTEADO, J. C. P.; VAZ, J. M. O Legado das Bifenilas Policloradas (PCBs). Quimica Nova, v. 24, n. 3, p. 390-398, 2001.

PERCHERON, G. et al. Nitrate and nitrite reduction of a sulphide-rich environment. Journal of Chemical Technology \& Biotechnology, v. 72, n. 3, p. 213-220, 1 jul. 1998.

PETTIGREW, C. A. et al. Chlorinated biphenyl mineralization by individual populations and consortia of freshwater bacteria. Appl. Envir. Microbiol., v. 56, n. 7, p. 2036-2045, 1 jul. 1990.

PIEPER, D. H.; SEEGER, M. Bacterial metabolism of polychlorinated biphenyls. Journal of Molecular Microbiology and Biotechnology, v. 15, n. 2-3, p. $121-138,2008$ a

PIEPER, D. H.; SEEGER, M. Bacterial metabolism of polychlorinated biphenyls. Journal of molecular microbiology and biotechnology, v. 15, $\mathrm{n}$. 2-3, p. 121-38, jan. 2008b

POTTER, D. W.; PAWLISZYN, J. Rapid determination of polyaromatic hydrocarbons and polychlorinated biphenyls in water using solid-phase microextraction and GC/MS. Environmental science \& technology, v. 28, n. 2, p. 298-305, 1 fev. 1994

PROVIDENTI, M. A.; LEE, H.; TREVORS, J. T. Selected factors limiting the microbial degradation of recalcitrant compounds. Journal of Industrial Microbiology, v. 12, n. 6, p. 379-395, 1993.

QUENSEN III, J. F.; TIEDJE, J. M.; BOYD, S. A. Reductive Dechlorination of Polychlorinated Biphenyls by Anaerobic Microorganisms from Sediments. Science, v. 242, p. 752-754, 1988.

RAVOT, G. et al. Thermotoga elfii sp. nov., a Novel Thermophilic Bacterium from an African Oil-Producing Well. International Journal of Systematic Bacteriology, v. 45, n. 2, p. 308-314, 1 abr. 1995.

REDDY, C. M. et al. The West Falmouth oil spill after thirty years: the persistence of petroleum hydrocarbons in marsh sediments. Environmental science \& technology, v. 36, n. 22, p. 4754-60, 15 nov. 2002

REN, Y. et al. An accurate QSRR model for the prediction of the GCxGC-TOFMS retention time of polychlorinated biphenyl (PCB) congeners. Analytical and bioanalytical chemistry, v. 388, n. 1, p. 165-72, maio 2007.

RHEE, G. Y. et al. Anaerobic dechlorination of aroclor 1242 as affected by some environmental conditions. Environmental Toxicology and Chemistry, v. 12, p. 1033-1039, 1993.

RIBANI, M. et al. Validação em métodos cromatográficos e eletroforéticos. Quimica Nova, v. 27, n. 5, p. 771-780, out. 2004. Hill Companies, 2001.

RITTMANN, B.; MCCARTY, P. Environmental Biotechnology: Principles and Applications. McGrew-Hill Companies. New York: McGrew-

ROBINSON, G. K.; LENN, M. J. The Bioremediation of Polychlorinated Biphenyls (PCBs): Problems and Perspectives. Biotechnology and Genetic Engineering Reviews, v. 12, n. 1, p. 139-188, dez. 1994. 
RODIL, R. et al. Selective extraction of trace levels of polychlorinated and polybrominated contaminants by supercritical fluid-solid-phase microextraction and determination by gas chromatography/mass spectrometry. Application to aquaculture fish feed and cultured marine . Analytical chemistry, v. 77 , n. 7, p. 2259-65, 1 abr. 2005. 469, 1 fev. 2003

ROSSETTI, S. Kinetic and phylogenetic characterization of an anaerobic dechlorinating microbial community. Microbiology, v. 149, n. 2, p. 459-

SABATINI, C. et al. Validação de método por cromatografia iônica para monitoramento de reatores de utilizados no tratamento de águas residuárias $37^{\mathrm{a}}$ Reunião Anual da Sociedade Brasileira de Química. Anais...2014

SAFE, S. H. Polychlorinated biphenyls (PCBs): environmental impact, biochemical and toxic responses, and implications for risk assessment. Critical reviews in toxicology, v. 24, n. 2, p. 87-149, 25 jan. 1994.

SAIA, F. T. et al. Anaerobic biodegradation of pentachlorophenol in a fixed-film reactor inoculated with polluted sediment from Santos-São Vicente Estuary, Brazil. Applied microbiology and biotechnology, v. 75, n. 3, p. 665-72, jun. 2007.

SAKAI, S. et al. Methanolinea mesophila sp. nov., a hydrogenotrophic methanogen isolated from rice field soil, and proposal of the archaeal family Methanoregulaceae fam. nov. within the order Methanomicrobiales. International journal of systematic and evolutionary microbiology, v. 62, n. Pt 6, p. 138995, jun. 2012.

SANFORD, R. A.; TIEDJE, J. M. Chlorophenol dechlorination and subsequent degradation in denitrifying microcosms fed low concentrations of nitrate. Biodegradation, v. 7, p. 425-434, 1997.

SANTOS, S. G. DOS et al. Comparison of Methanol, Ethanol, and Methane as Electron Donors for Denitrification. Environmental Engineering Science, v. 21, n. 3, p. 313-320, 29 maio 2004.

SARFARAZ, S. et al. Anoxic treatment of phenolic wastewater in sequencing batch reactor. Water research, v. 38, n. 4, p. 965-71, fev. 2004

SAYLER, G. S.; SHON, M.; COLWELL, R. R. Growth of an estuarinePseudomonas sp. on polychlorinated biphenyl. Microbial ecology, v. 3, n. 3, p. 241-55, set. 1977.

SCHERR, K. E. et al. Changes in bacterial communities from anaerobic digesters during petroleum hydrocarbon degradation. Journal of biotechnology, v. 157 , n. 4 , p. $564-72,20$ fev. 2012.

SCHLESNER, H. et al. Taxonomic and phylogenetic studies on a new taxon of budding, hyphal Proteobacteria, Hirschia baltica gen. nov., sp. nov. International journal of systematic bacteriology, v. 40, n. 4, p. 443-51, out. 1990.

SCHÖLLHORN, A. et al. Comparison of different substrates for the fast reductive dechlorination of trichloroethene under groundwater conditions. Water Research, v. 31, n. 6, p. 1275-1282, jun. 1997.

SEKIGUCHI, Y. et al. Anaerolinea thermophila gen. nov., sp. nov. and Caldilinea aerophila gen. nov., sp. nov., novel filamentous thermophiles that represent a previously uncultured lineage of the domain Bacteria at the subphylum level. International journal of systematic and evolutionary microbiology, v. 53, n. Pt 6, p. 1843-51, nov. 2003

SEVIOUR, R. J.; NIELSEN, P. H. Microbial Ecology of Activated Sludge. [s.1.] IWA Publishing, 2010

SHIRATORI, H. et al. Lutispora thermophila gen. nov., sp. nov., a thermophilic, spore-forming bacterium isolated from a thermophilic methanogenic bioreactor digesting municipal solid wastes. International journal of systematic and evolutionary microbiology, v. 58, n. Pt 4, p. 964-9, abr. 2008.

SHUAI, J.-J. et al. Identification and analysis of polychlorinated biphenyls (PCBs)-biodegrading bacterial strains in Shanghai. Current microbiology, v. 61 , n. 5, p. $477-83$, nov. 2010.

SIERRA-ALVAREZ, R.; LETTINGA, G. The effect of aromatic structure on the inhibition of acetoclastic methanogenesis in granular sludge. Applied Microbiology and Biotechnology, v. 34, n. 4, jan. 1991.

SILVA, M. R. DE L. E. Caracterização da comunidade microbiana de biofilme anaeróbio em presença de bifenilas policloradas. [s.1.] Universidade de São Paulo, 27 abr. 2012.

SKRINDE, J. R.; BHAGAT, S. K. Industrial Wastes as Carbon Sources in Biological Denitrification on JSTOR. Water Pollution Control Federation, v. 54 , n. 4 , p. $370-377,1982$.

SONG, B.; PALLERONI, N. J.; HÄGGBLOM, M. M. Isolation and characterization of diverse halobenzoate-degrading denitrifying bacteria from soils and sediments. Applied and environmental microbiology, v. 66, n. 8, p. 3446-53, ago. 2000

SOUSA, D. Z. et al. Molecular assessment of complex microbial communities degrading long chain fatty acids in methanogenic bioreactors. FEMS microbiology ecology, v. 60 , n. 2, p. 252-65, 1 maio 2007

SOUZA, T. S. O. DE. Desnitrificação autotrófica usando sulfeto como doador de elétrons para remoção de nitrogênio de efluentes de reatores anaeróbios. [s.l: s.n.]. 
STAMS, A. J. M. Metabolic interactions between anaerobic bacteria in methanogenic environments. Antonie van Leeuwenhoek, v. 66, n. 1-3, p. 271-294, 1994.

STRÖMPL, C. et al. Oceanicaulis alexandrii gen. nov., sp. nov., a novel stalked bacterium isolated from a culture of the dinoflagellate Alexandrium tamarense (Lebour) Balech. International journal of systematic and evolutionary microbiology, v. 53, n. Pt 6, p. 1901-6, nov. 2003.

SUN, H. et al. Nitrite Accumulation during the Denitrification Process in SBR for the Treatment of Pre-treated Landfill Leachate. Chinese Journal of Chemical Engineering, v. 17, n. 6, p. 1027-1031, dez. 2009

SYLVESTRE, M. Isolation Method for Bacterial Isolates Capable of Growth on p-Chlorobiphenyl. Appl. Envir. Microbiol., v. 39, n. 6, p. 12231224, 1 jun. 1980.

SYLVESTRE, M.; SONDOSSI, M. Selection of enhanced polychlorinated biphenyl-degrading bacterial strains for bioremediation: consideration of branching pathways. In: CHAUDHRY, G. R. (Ed.). . Biological degradation and bioremediation of toxic chemicals. Portland, Oregon: Dioscorides Press, 1994. p. 33-73.

TAIRA, K. et al. Analysis of bph operon from the polychlorinated biphenyl-degrading strain of Pseudomonas pseudoalcaligenes KF707. Journal of Biological Chemistry, v. 267, n. 7, p. 4844-4853, 5 mar. 1992.

TAKAHASHI, S. et al. Development of a prokaryotic universal primer for simultaneous analysis of bacteria and archaea using next-generation sequencing. PloS one, v. 9, n. 8, p. e105592, jan. 2014.

TAKAI, K. et al. Sulfurimonas paralvinellae sp. nov., a novel mesophilic, hydrogen- and sulfur-oxidizing chemolithoautotroph within the Epsilonproteo-bacteria isolated from a deep-sea hydrothermal vent polychaete nest, reclassification of Thiomicrospira denitrificans as S. International Journal of Systematic and Evolutionary Microbiology, v. 56, n. 8, p. 1725-1733, 2006.

TAMAOKA, J.; HA, D.-M.; KOMAGATA, K. Reclassification of Pseudomonas acidovorans den Dooren de Jong 1926 and Pseudomonas testosteroni Marcus and Talalay 1956 as Comamonas acidovorans comb. nov. and Comamonas testosteroni comb. nov., with an Emended Description of the Genus Comamonas. International Journal of Systematic Bacteriology, v. 37, n. 1, p. 52-59, 1 jan. 1987.

TARTAKOVSKY, B.; HAWARI, J.; GUIOT, S. R. ENHANCED DECHLORINATION OF AROCLOR 1242 IN AN ANAEROBIC CONTINUOUS BIOREACTOR. Water Research, v. 34, n. 1, p. 85-92, 2000.

TCHOBAnOGlOUS, G.; BURTON, F. L.; STENSEL, H. D. Wastewater Engineering: Treatment and Reuse. [s.l.] Metcalf \& Eddy (Inc), 2003.

TIEDJE, J. M. et al. Microbial reductive dechlorination of PCBs. Biodegradation, v. 4, p. 231-240, 1993.

TOBISZEWSKI, M.; NAMIEŚNIK, J. Determination of chlorinated solvents in industrial water and wastewater by DAI-GC-ECD. Analytical and bioanalytical chemistry, v. 399, n. 10, p. 3565-72, abr. 2011.

TRZCINSKI, A. P.; OFOEGBU, N.; STUCKEY, D. C. Anaerobic toxicity assay of plasticisers. Journal of environmental science and health. Part A, Toxic/hazardous substances \& environmental engineering, v. 47, n. 8, p. 1082-6, 16 jan. 2012.

TSEZOS, M.; BELL, J. P. Significance of biosorption for the hazardous organics removal efficiency of a biological reactor. Water Research, v. 22, n. 3, p. 391-394, mar. 1988 .

TSEZOS, M.; BELL, J. P. Comparison of the biosorption and desorption of hazardous organic pollutants by live and dead biomass. Water Research, v. 23 , n. 5 , p. $561-568,1989$.

TSEZOS, M.; WANG, X. Study on the Kinetics of Hazardous Pollutants Adsorption and Desorption by Biomass: Mechanistic Considerations. Journal of Chemical Technology and Biotechnology, v. 50, n. 4, p. 507-521, 24 abr. 1991.

UNEP UNITED NATIONS ENVIRONMENT PROGRAMME. Conference of the Parties to the Stockholm Convention on Persistent Organic Pollutants Fifth meeting: Reports of the meetings of the advisory committee of the polychlorinated biphenyls elimination network. Geneva: [s.n.]. Disponível em: <http://www.popsalgerie.com/en/uploads/webmaster/english/UNEP-POPS-COP.5-INF-4.English.pdf〉. Acesso em: 24 fev. 2015.

US EPA, U. S. E. P. Polychlorinated Biphenyls (PCBs)| US EPA. Disponível em: <http://www.epa.gov/epawaste/hazard/tsd/pcbs/index.htm>. Acesso em: 5 ago. 2015 .

VALOR, I. et al. SPME of 52 pesticides and polychlorinated biphenyls: Extraction efficiencies of the SPME coatings poly(dimethylsiloxane), polyacrylate, poly(dimethylsiloxane)-divinylbenzene, Carboxen-poly(dimethylsiloxane), and Carbowax-divinylbenzene. Journal of Separation Science, v. 24, n. 1, p. 39-48, 1 jan. 2001.

VAN BODEGOM, P. Microbial maintenance: a critical review on its quantification. Microbial ecology, v. 53, n. 4, p. 513-23, maio 2007. 1 abr. 1995 .

VAN DE GRAAF, A. et al. Anaerobic oxidation of ammonium is a biologically mediated process. Appl. Envir. Microbiol., v. 61, n. 4, p. 1246-1251,

VAZOLLER, R. F. Avaliação do ecossistema microbiano de um biodigestor anaeróbio de fluxo ascendente e manta de lodo, operado com vinhaça sob condições termofílicas. [s.l.] Universidade de São Paulo, 1995. 
VOGELS, G. D.; KELTJENS, J. T.; VAN DER DRIFT, C. Biogeochemistry of methane production. In: ZEHNDER, A. (Ed.). . Biology of anaerobic microorganisms. New York: John Wiley \& Sons, 1988. p. 707-770.

VOS, P. et al. Bergey's Manual of Systematic Bacteriology - Vol 3: The Firmicutes. [s.l.] Springer Science \& Business Media, 2009.

VOS, P. et al. Bergey's Manual of Systematic Bacteriology: Volume 3: The Firmicutes. [s.1.] Springer Science \& Business Media, 2011.

WANG, Q. et al. Naive Bayesian classifier for rapid assignment of rRNA sequences into the new bacterial taxonomy. Applied and environmental microbiology, v. 73, n. 16, p. 5261-7, ago. 2007.

WANG, S.; HE, J. Phylogenetically Distinct Bacteria Involve Extensive Dechlorination of Aroclor 1260 in Sediment-Free Cultures. PLoS ONE, v. 8, n. 3, p. e59178, 15 mar. 2013a.

WANG, S.; HE, J. Dechlorination of commercial PCBs and other multiple halogenated compounds by a sediment-free culture containing Dehalococcoides and Dehalobacter. Environmental science \& technology, v. 47, n. 18, p. 10526-34, 17 set. 2013 b.

WANG, X. et al. Pyrosequencing analysis of bacterial diversity in 14 wastewater treatment systems in China. Applied and environmental microbiology, v. 78 , n. 19 , p. $7042-7,1$ out. 2012.

WARMUTH, A.; OHNO, K. The PCBs elimination network: the information exchange platform created for the risk reduction of polychlorinated biphenyls (PCBs). Journal of epidemiology and community health, v. 67, n. 1, p. 4-5, 29 jan. 2013.

WARREN, E. et al. Inhibition of Acetoclastic Methanogenesis in Crude Oil- and Creosote-Contaminated Groundwater. Bioremediation Journal, v. 7, n. 3-4, p. 139-149, 2003.

WATTS, J. E. M. et al. Comparative analysis of polychlorinated biphenyl-dechlorinating communities in enrichment cultures using three different molecular screening techniques. Environmental Microbiology, v. 3, n. 11, p. 710-719, nov. 2001.

WIEGEL, J.; WU, Q. Microbial reductive dehalogenation of polychlorinated biphenyls. FEMS Microbiology Ecology, v. 32, p. 1-15, 2000.

WIEGEL, J.; ZHANG, X.; WU, Q. Anaerobic dehalogenation of hydroxylated polychlorinated biphenyls by Desulfitobacterium dehalogenans. Applied and Environmental Microbiology, v. 65, n. 5, p. 2217-2221, maio 1999.

WILDEMAN, S. DE et al. Growth-Substrate Dependent Dechlorination of 1,2-Dichloroethane by a Homoacetogenic Bacterium. Biodegradation, v. 14, n. 4, p. 241-247, 1 ago. 2003.

WILDERER, P. A.; JONES, W. L.; DAU, U. Competition in denitrification systems affecting reduction rate and accumulation of nitrite. Water Research, v. 21, n. 2, p. 239-245, fev. 1987.

WILHM, J. L.; DORRIS, T. C. Biological Parameters for Water Quality Criteria. BioScience, v. 18, n. 6, p. 477-481, 1968.

WU, Q. et al. Identification of a Bacterium That Specifically Catalyzes the Reductive Dechlorination of Polychlorinated Biphenyls with Doubly Flanked Chlorines. Applied and environmental microbiology, v. 68, n. 2, p. 807-812, 2002.

WU, Q.; SOWERS, K. R.; MAY, H. D. Establishment of a Polychlorinated Biphenyl-Dechlorinating Microbial Consortium , Specific for Doubly Flanked Chlorines, in a Defined, Sediment-Free Medium. v. 66, n. 1, p. 49-53, 2000.

XIAO, Y. et al. Coexistence of nitrifiers, denitrifiers and Anammox bacteria in a sequencing batch biofilm reactor as revealed by PCR-DGGE. Journal of applied microbiology, v. 106, n. 2, p. 496-505, fev. 2009.

$\mathrm{XU}$, K. et al. Typical methanogenic inhibitors can considerably alter bacterial populations and affect the interaction between fatty acid degraders and homoacetogens. Applied Microbiology and Biotechnology, v. 87, p. 2267-2279, 2010

YAMADA, T. et al. Diversity, localization, and physiological properties of filamentous microbes belonging to Chloroflexi subphylum I in mesophilic and thermophilic methanogenic sludge granules. Applied and environmental microbiology, v. 71, n. 11, p. 7493-503, 1 nov. 2005.

YAMADA, T. et al. Anaerolinea thermolimosa sp. nov., Levilinea saccharolytica gen. nov., sp. nov. and Leptolinea tardivitalis gen. nov., sp. nov., novel filamentous anaerobes, and description of the new classes Anaerolineae classis nov. and Caldilineae classis nov. in the. INTERNATIONAL JOURNAL OF SYSTEMATIC AND EVOLUTIONARY MICROBIOLOGY, v. 56, n. 6, p. 1331-1340, 1 jun. 2006.

YAMAMOTO, K. et al. Complete Genome Sequence of Methanoregula formicica SMSPT, a Mesophilic Hydrogenotrophic Methanogen Isolated from a Methanogenic Upflow Anaerobic Sludge Blanket Reactor. Genome announcements, v. 2, n. 5, p. e00870-14, 31 jan. 2014.

YAN, T.; LAPARA, T. M.; NOVAK, P. J. The reductive dechlorination of 2,3,4,5-tetrachlorobiphenyl in three different sediment cultures: evidence for the involvement of phylogenetically similar Dehalococcoides-like bacterial populations. FEMS microbiology ecology, v. 55, n. 2, p. 248-61, fev. 2006.

YE, D. et al. Evidence for para dechlorination of polychlorobiphenyls by methanogenic bacteria. Applied and environmental microbiology, v. 61, n. 6 , p. 2166-71, jun. 1995 . 
YOSHIDA, N. et al. Reductive Dechlorination of Polychlorinated Biphenyls and Dibenzo-p-Dioxins in an Enrichment Culture Containing Dehalobacter Species. Microbes and Environments, v. 24, n. 4, p. 343-346, 1 jan. 2009.

ZANAROLI, G. et al. Characterization of the microbial community from the marine sediment of the Venice lagoon capable of reductive dechlorination of coplanar polychlorinated biphenyls (PCBs). Journal of hazardous materials, v. 178, n. 1-3, p. 417-26, 15 jun. 2010.

ZANAROLI, G. et al. A Chloroflexi bacterium dechlorinates polychlorinated biphenyls in marine sediments under in situ-like biogeochemical conditions. Journal of Hazardous Materials, v. 209-210, p. 449-457, mar. 2012a.

ZANAROLI, G. et al. Enhancement of microbial reductive dechlorination of polychlorinated biphenyls (PCBs) in a marine sediment by nanoscale zerovalent iron (NZVI) particles. Journal of Chemical Technology \& Biotechnology, v. 87, n. 9, p. 1246-1253, 28 set. 2012 b.

ZHANG, C.; BENNETT, G. N. Biodegradation of xenobiotics by anaerobic bacteria. Applied microbiology and biotechnology, v. 67, n. 5, p. 60018 , jun. 2005

ZHAXYBAYEVA, O. et al. Genome Sequence of the Mesophilic Thermotogales Bacterium Mesotoga prima MesG1.Ag.4.2 Reveals the Largest Thermotogales Genome To Date. GENOME BIOLOGY AND EVOLUTION, v. 4, n. 8, p. 812-820, 2012.

ZWIERNIK, M. J.; QUENSEN III, J. F.; BOYD, S. A. FeSO4 Amendments Stimulate Extensive Anaerobic PCB Dechlorination. Environmental Science \& Technology, v. 32, p. 3360-3365, 1998.

ZWIETERING, M. H. et al. Modeling of the Bacterial Growth Curve Modeling of the Bacterial Growth Curve. Applied and environmental microbiology, v. 56, n. 6, p. 1875-1881, 1990 


\section{Apêndices}

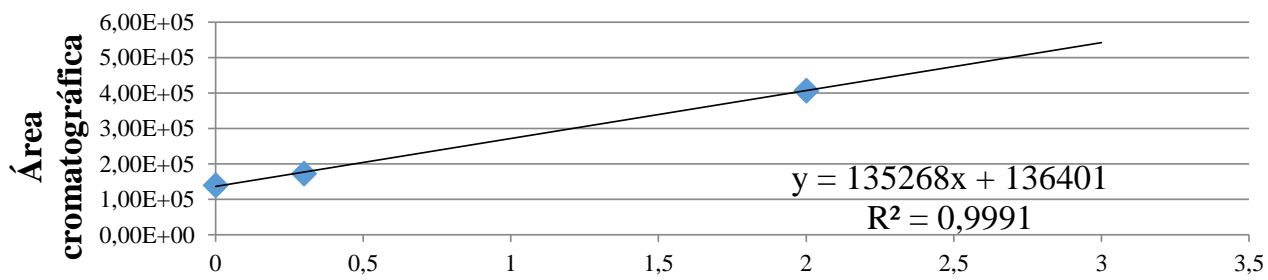

(a)

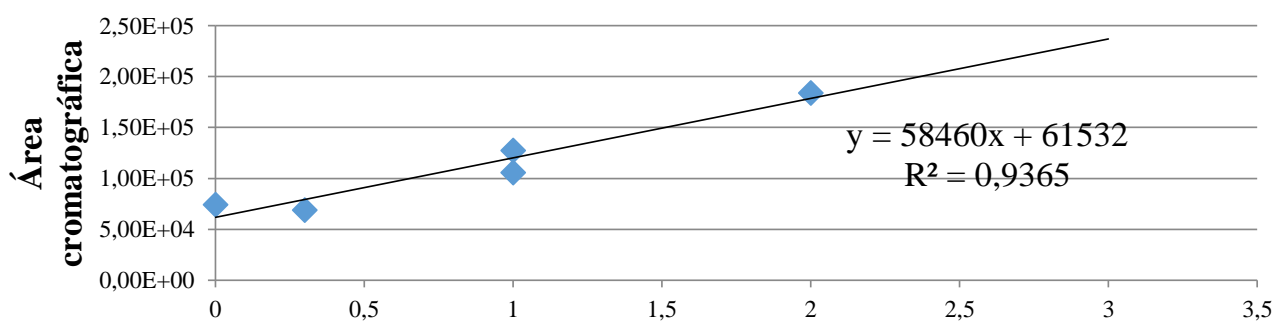

(b)

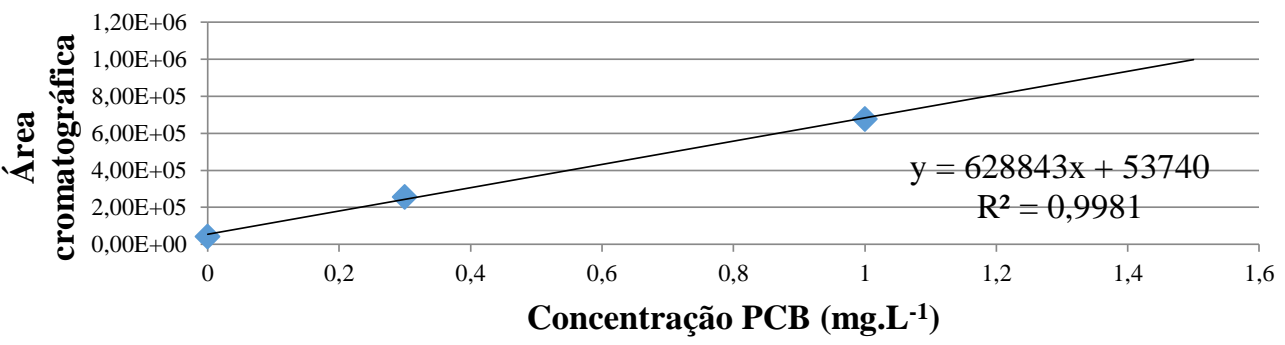

(c)

Figura A. 1 Curva de extração utilizando a técnica de SPME com Adição de Padrão nos Reatores Anaeróbios para o PCB 10. (a) Análise no MT0, (b) Análise no MT1 e (c) Análise no MT2. 


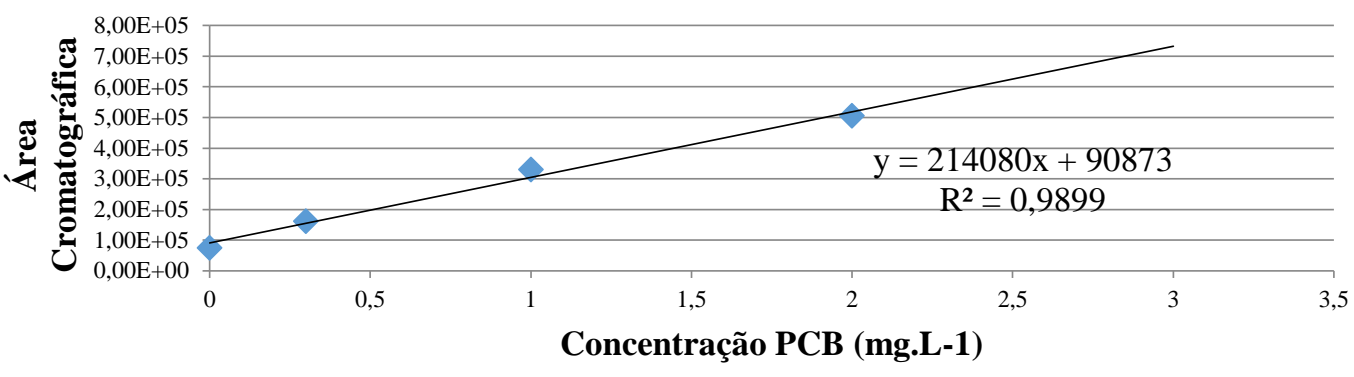

(a)

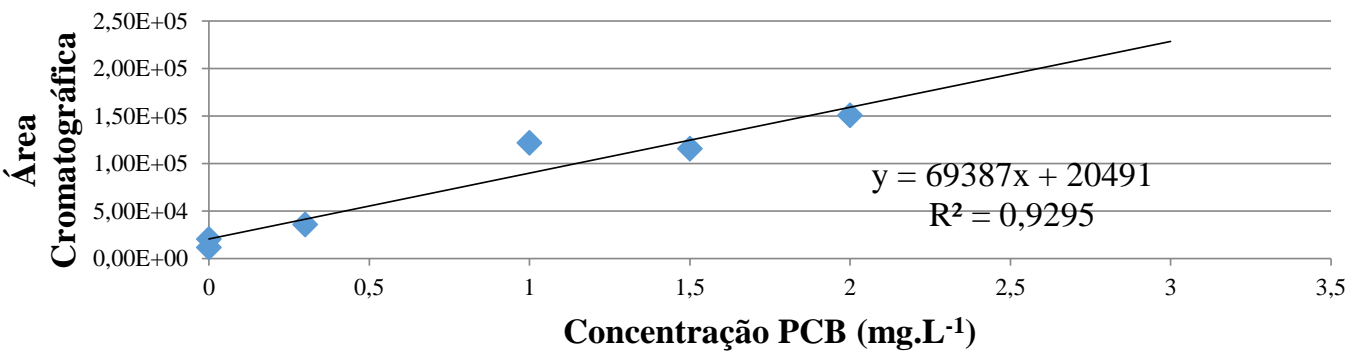

(b)

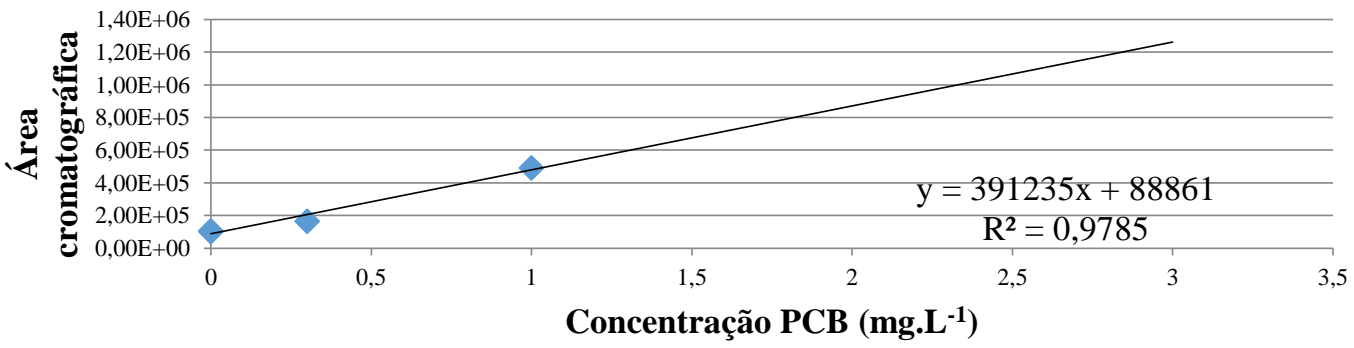

(c)

Figura A. 2 Curva de extração utilizando a técnica de SPME com Adição de Padrão nos Reatores Anaeróbios para o PCB 28. (a) Análise no MT0, (b) Análise no MT1 e (c) Análise no MT2. 


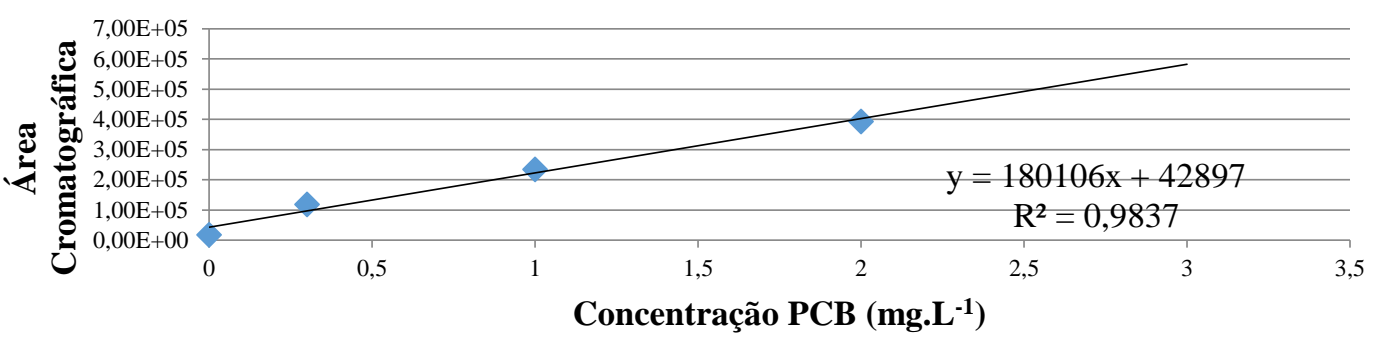

(a)

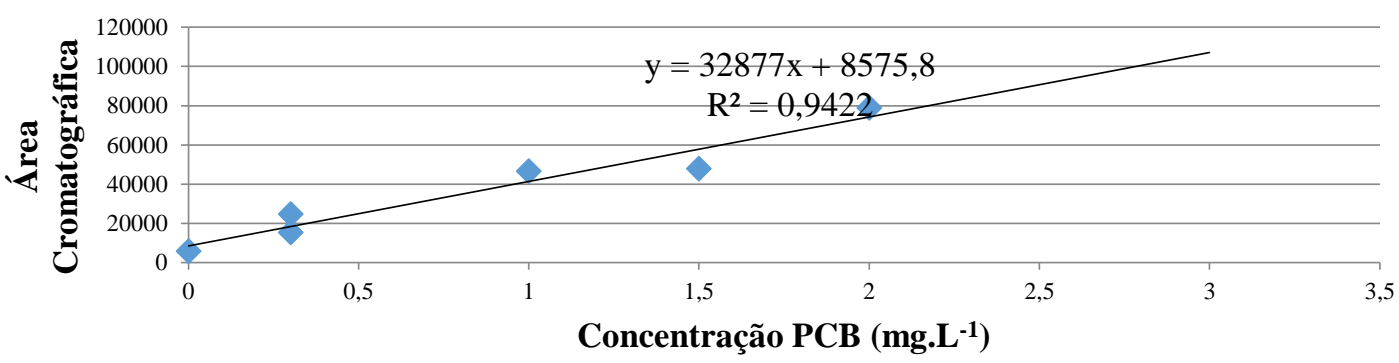

(b)

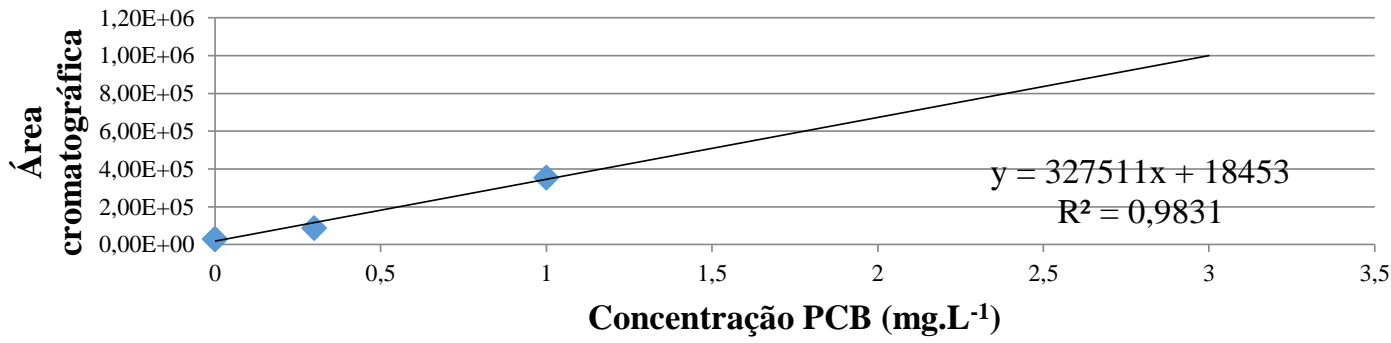

(c)

Figura A. 3 Curva de extração utilizando a técnica de SPME com Adição de Padrão nos Reatores Anaeróbios para o PCB 52. (a) Análise no MT0, (b) Análise no MT1 e (c) Análise no MT2. 


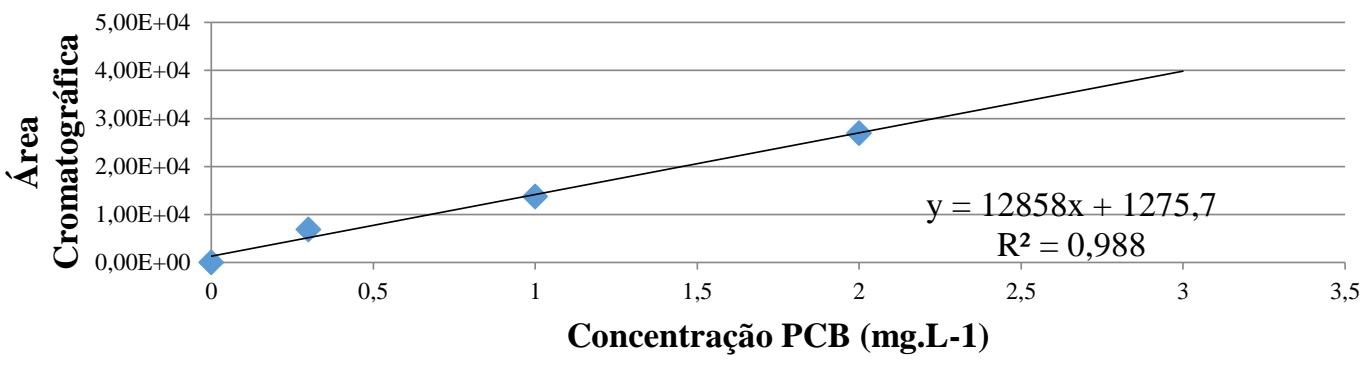

(a)

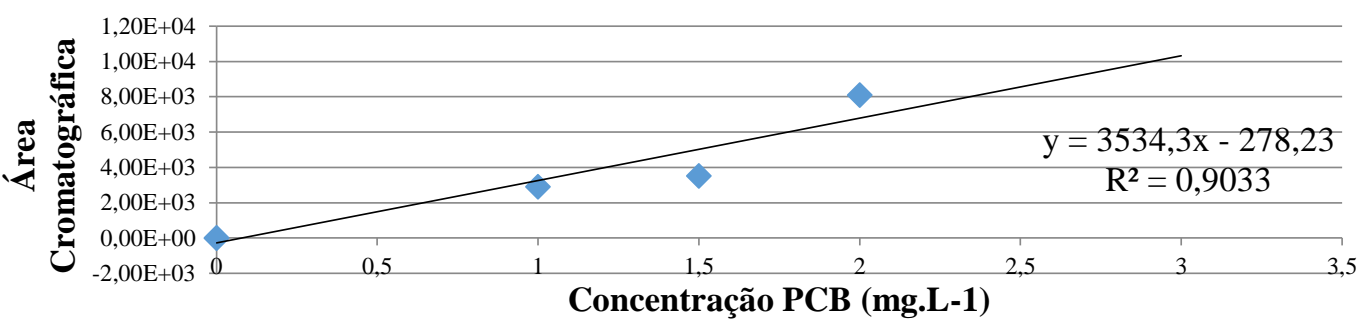

(b)

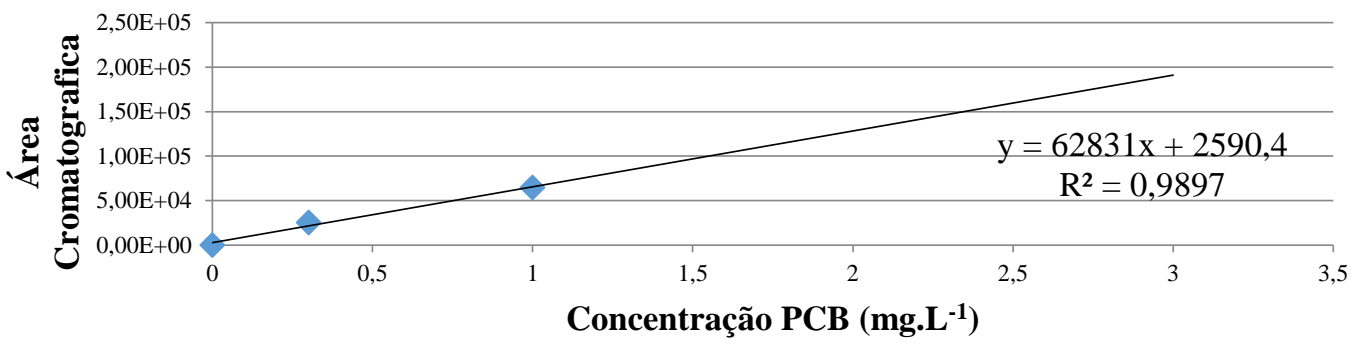

(c)

Figura A. 4 Curva de extração utilizando a técnica de SPME com Adição de Padrão nos Reatores Anaeróbios para o PCB 153. (a) Análise no MT0, (b) Análise no MT1 e (c) Análise no MT2. 


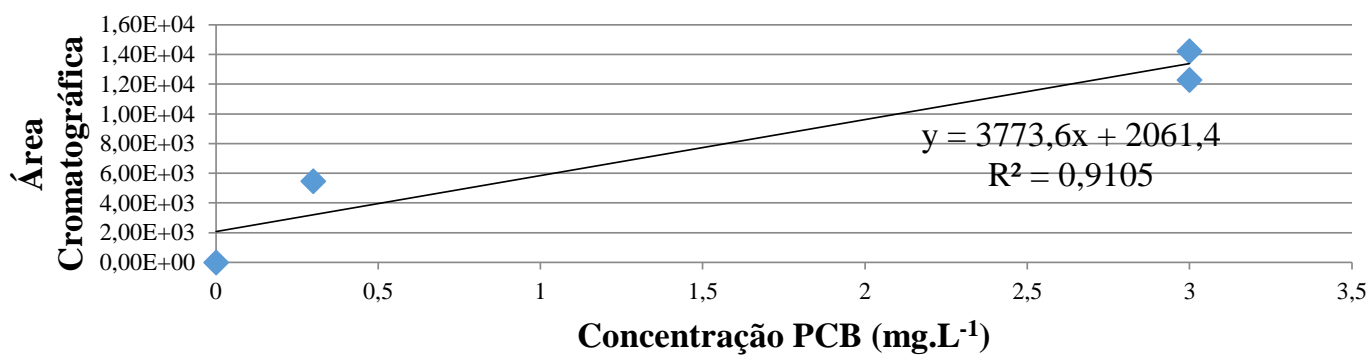

(a)

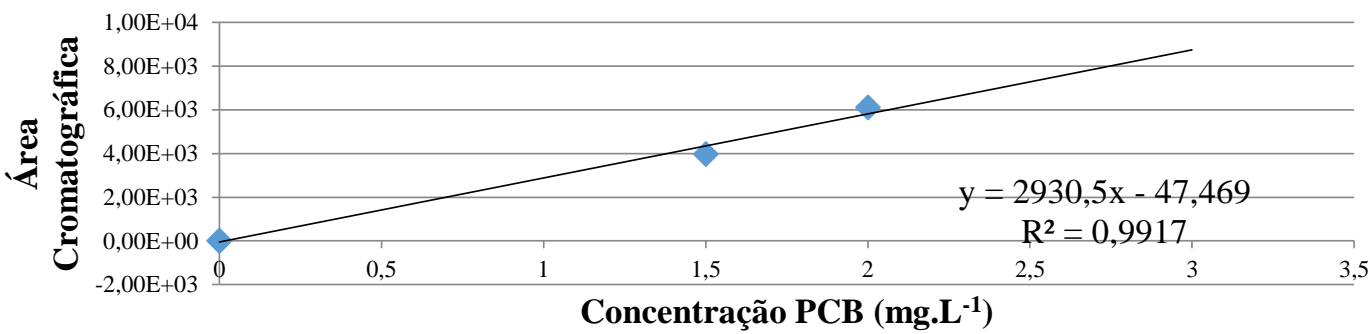

(b)

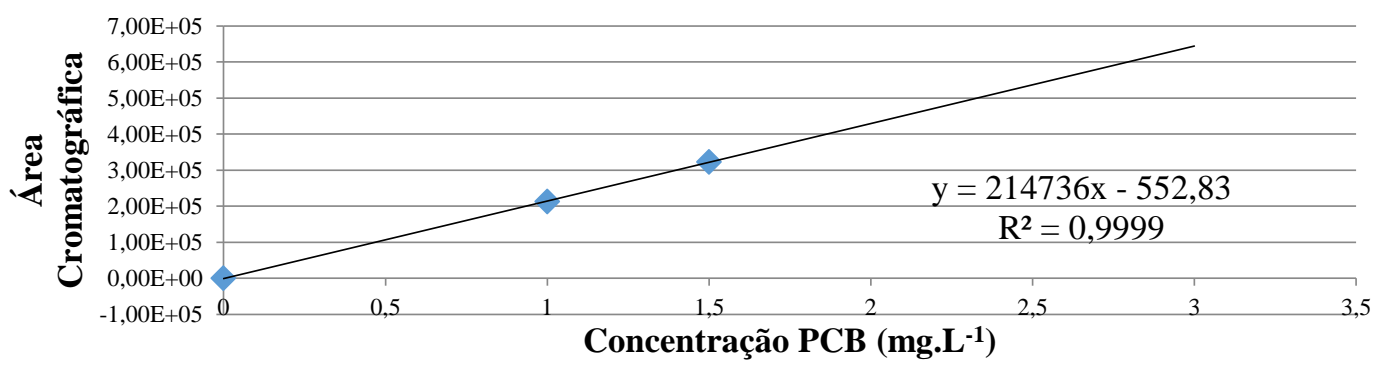

(c)

Figura A. 5 Curva de extração utilizando a técnica de SPME com Adição de Padrão nos Reatores Anaeróbios para o PCB 138. (a) Análise no MT0, (b) Análise no MT1 e (c) Análise no MT2. 


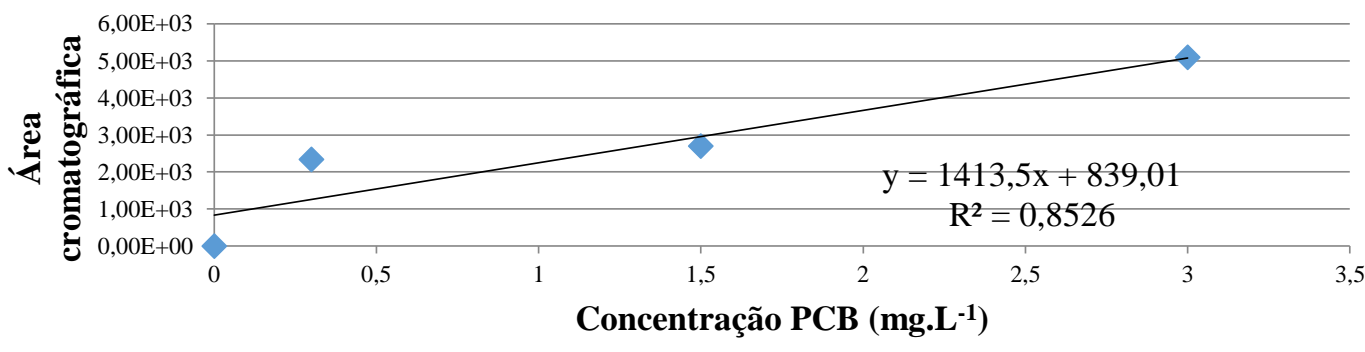

(a)

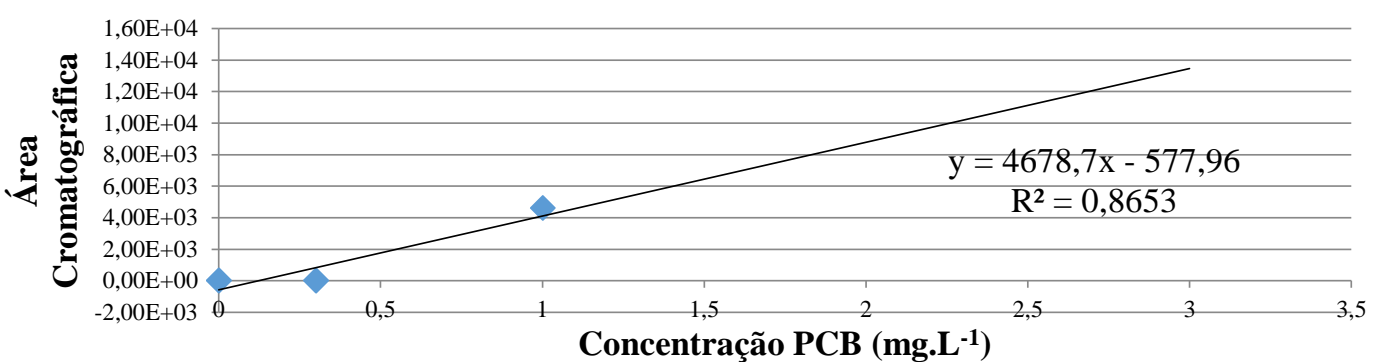

(b)

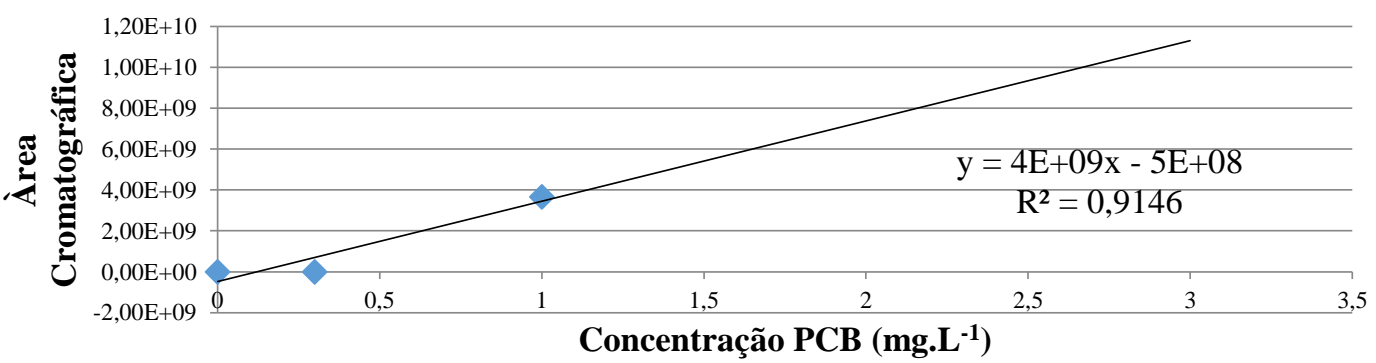

(c)

Figura A. 6 Curva de extração utilizando a técnica de SPME com Adição de Padrão nos Reatores Anaeróbios para o PCB 180. (a) Análise no MT0, (b) Análise no MT1 e (c) Análise no MT2. 


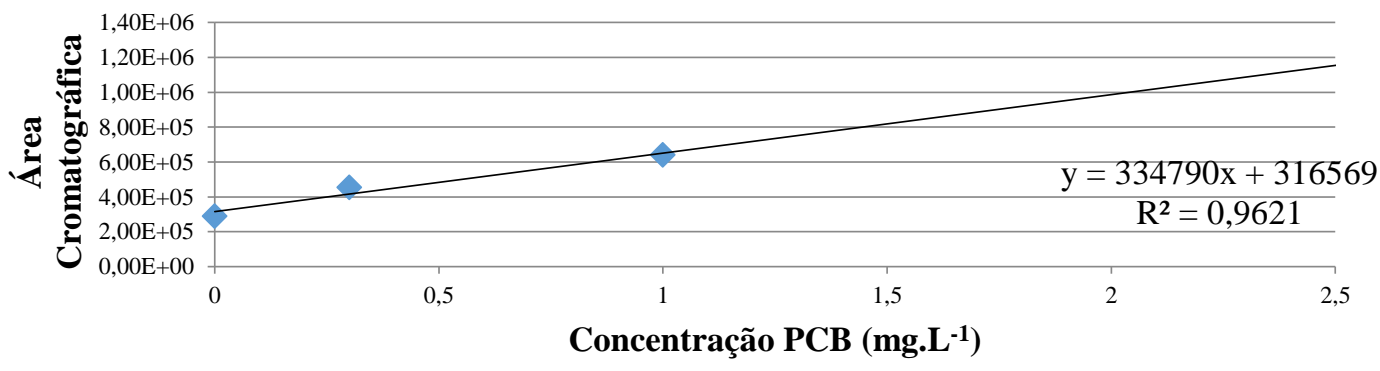

(a)

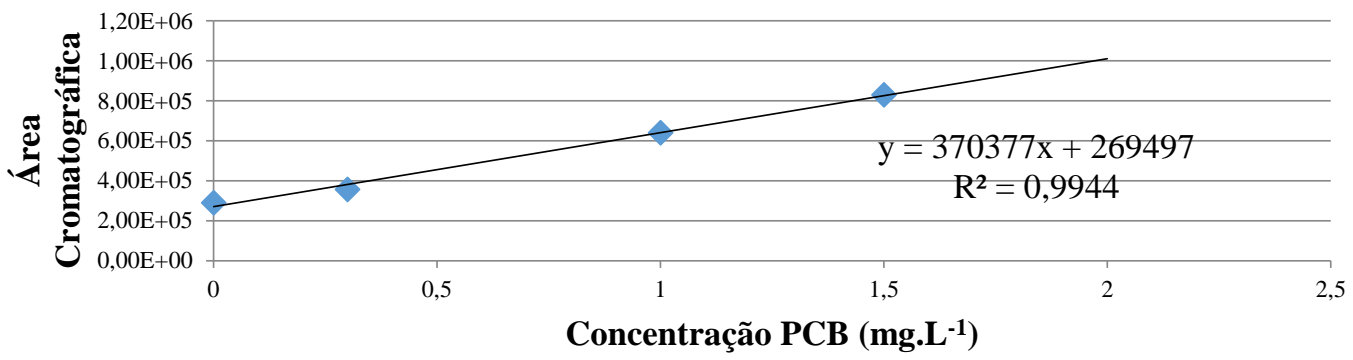

(b)

Figura A. 7 Curva de extração utilizando a técnica de SPME com Adição de Padrão nos Reatores Controle Anaeróbio para o PCB 10. (a) Análise no CMT0 e (b) Análise no CMT2.

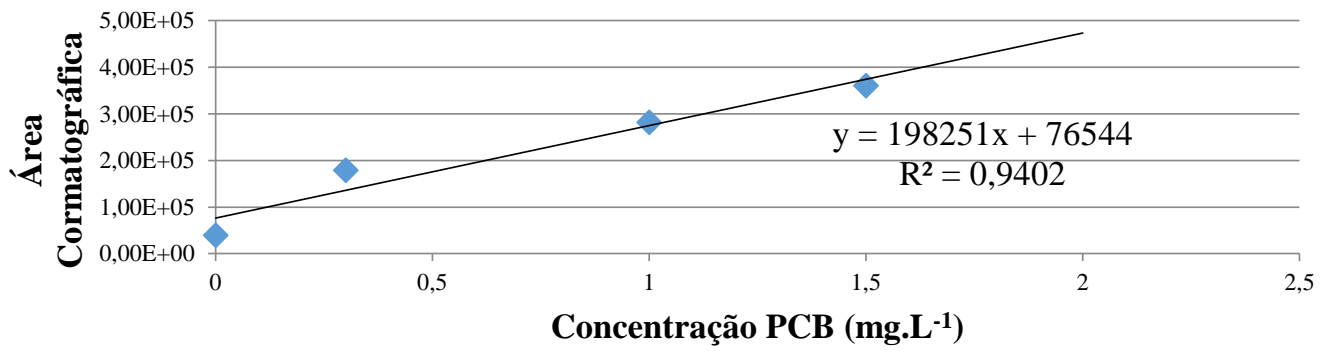

(a)

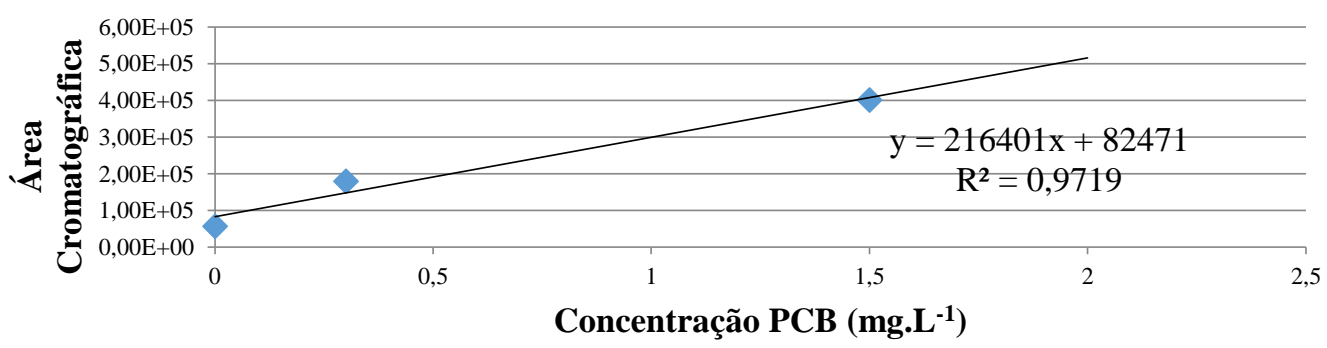

(b)

Figura A. 8 Curva de extração utilizando a técnica de SPME com Adição de Padrão nos Reatores Controle Anaeróbio para o PCB 28. (a) Análise no CMT0 e (b) Análise no CMT2. 


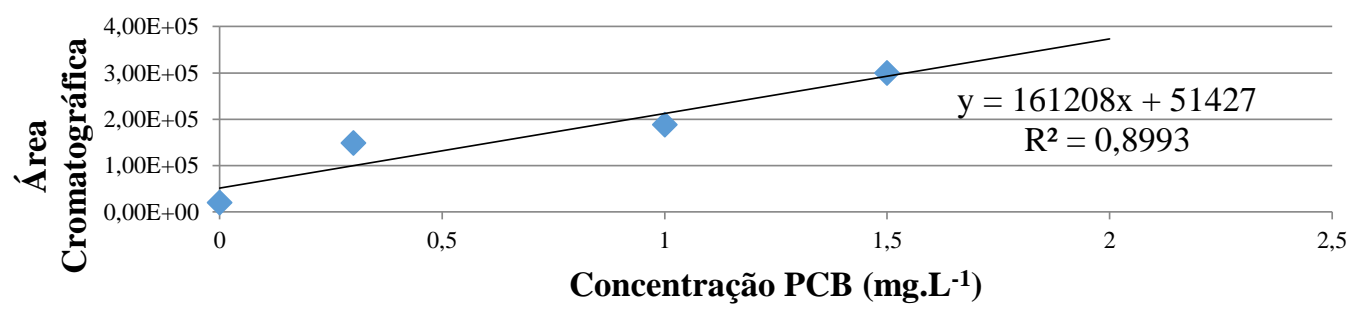

(a)

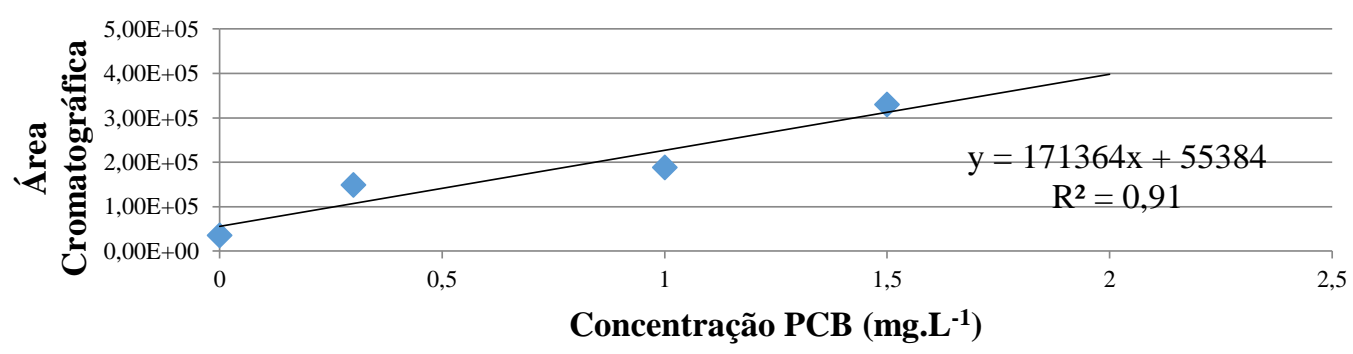

(b)

Figura A. 9 Curva de extração utilizando a técnica de SPME com Adição de Padrão nos Reatores Controle Anaeróbio para o PCB 52. (a) Análise no CMT0 e (b) Análise no CMT2.

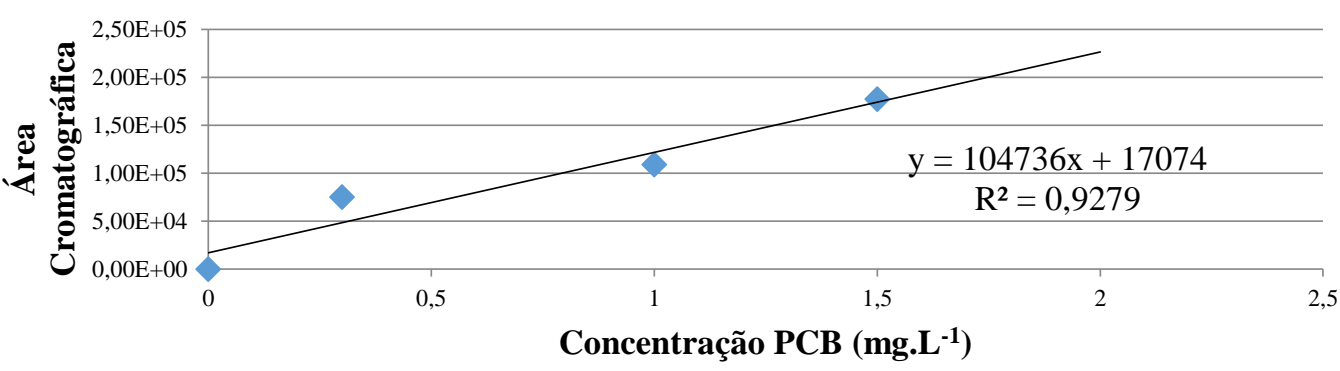

(a)

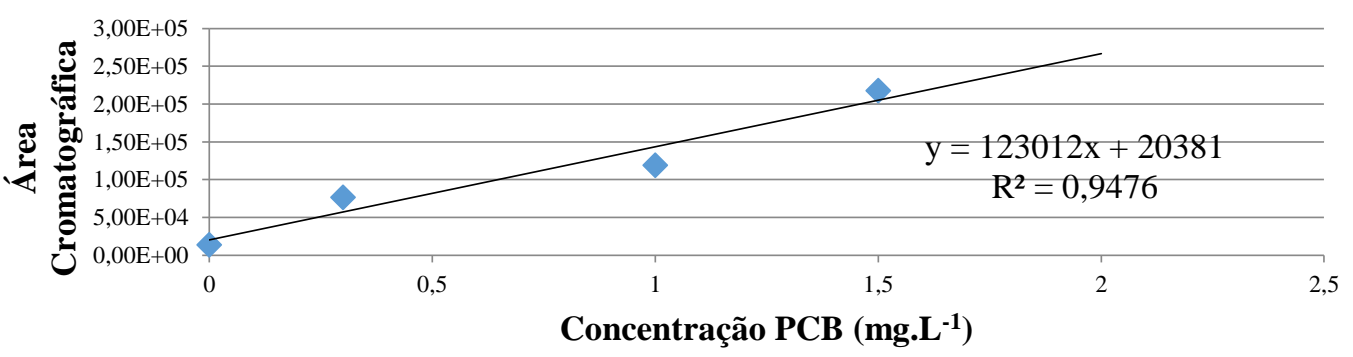

(b)

Figura A. 10 Curva de extração utilizando a técnica de SPME com Adição de Padrão nos Reatores Controle Anaeróbio para o PCB 153. (a) Análise no CMT0 e (b) Análise no CMT2. 


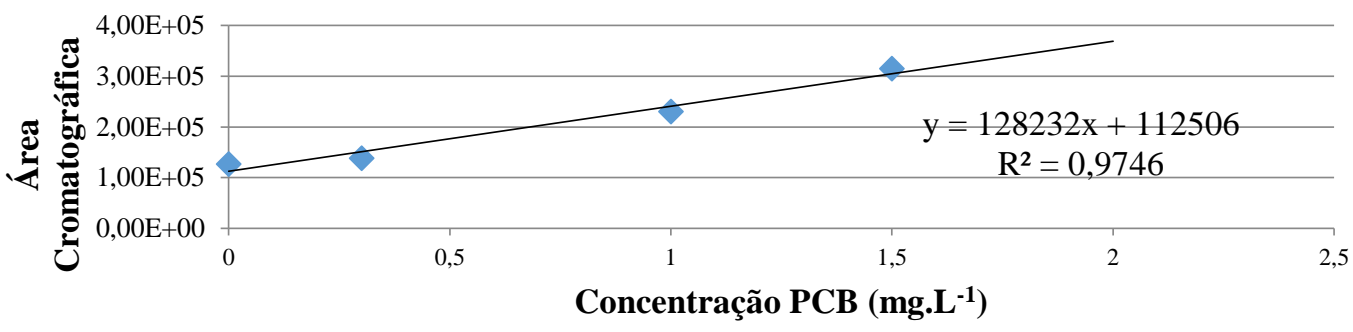

(a)

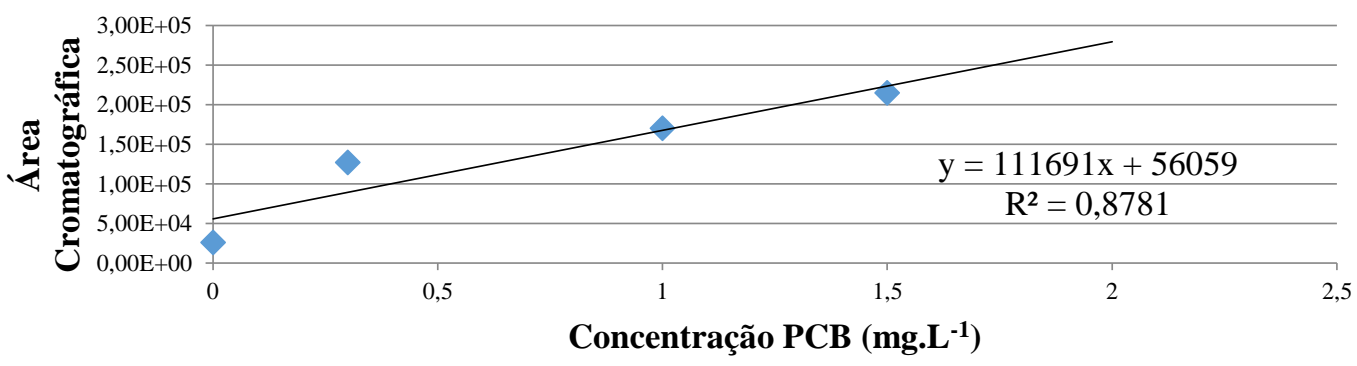

(b)

Figura A. 11 Curva de extração utilizando a técnica de SPME com Adição de Padrão nos Reatores Controle Anaeróbio para o PCB 138. (a) Análise no CMT0 e (b) Análise no CMT2.

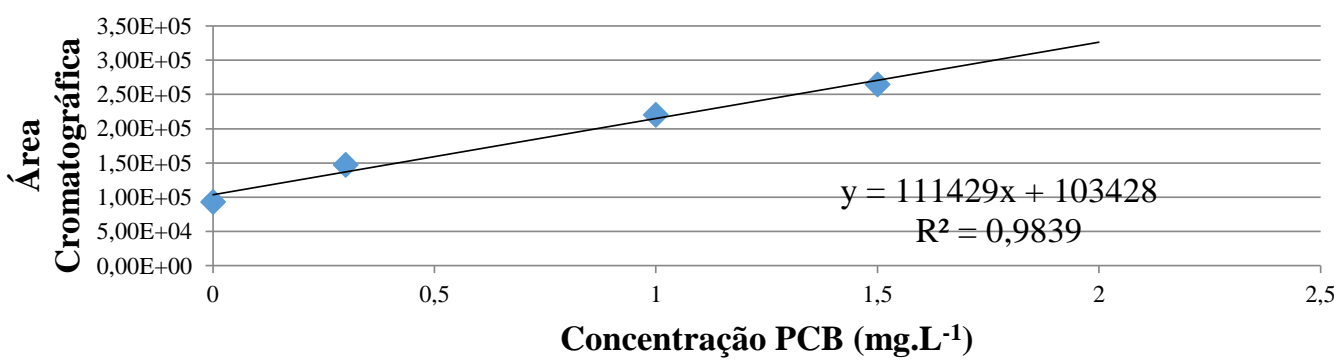

T0

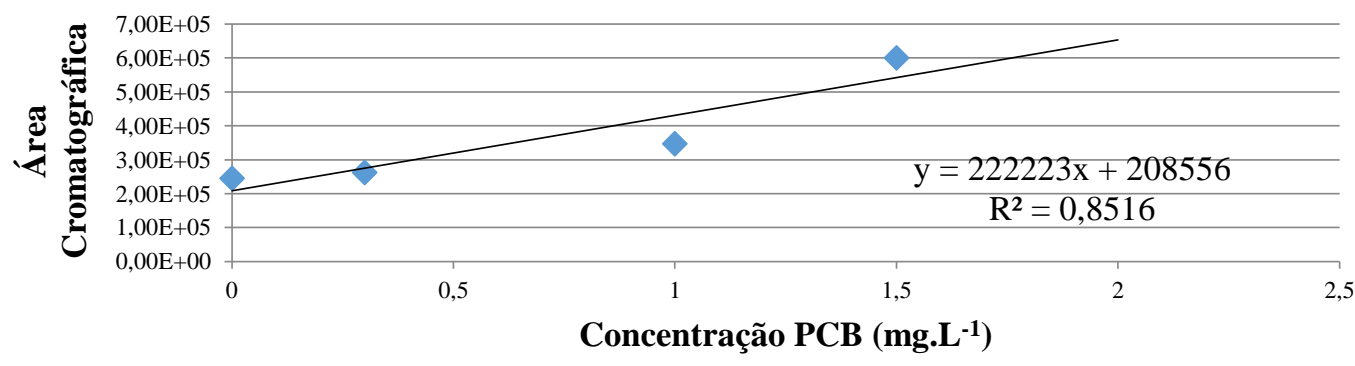

$\mathrm{T} 2$

Figura A. 12 Curva de extração utilizando a técnica de SPME com Adição de Padrão nos Reatores Controle Anaeróbio para o PCB 180. (a) Análise no CMT0 e (b) Análise no CMT2. 


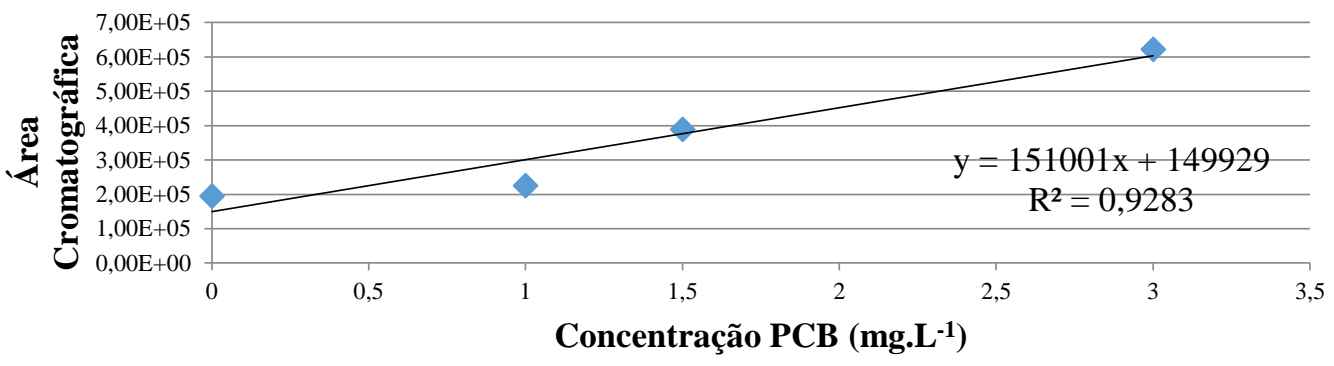

(a)

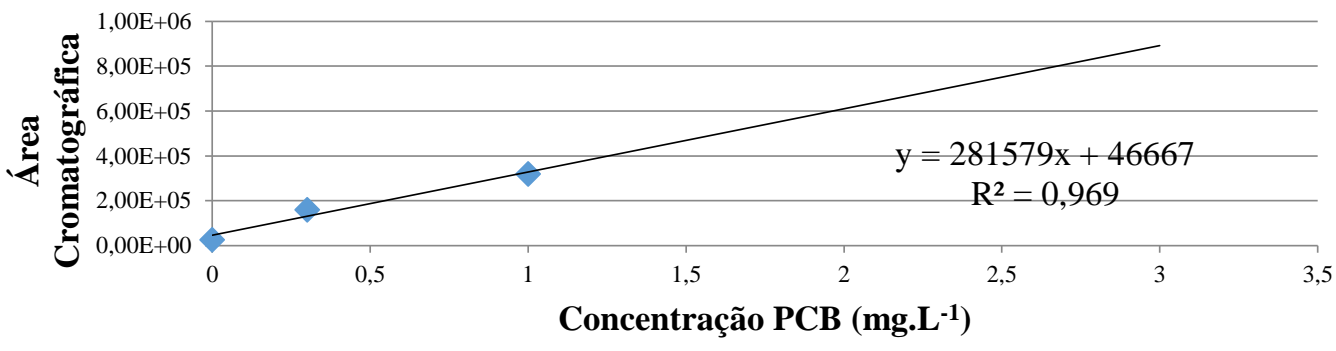

(b)

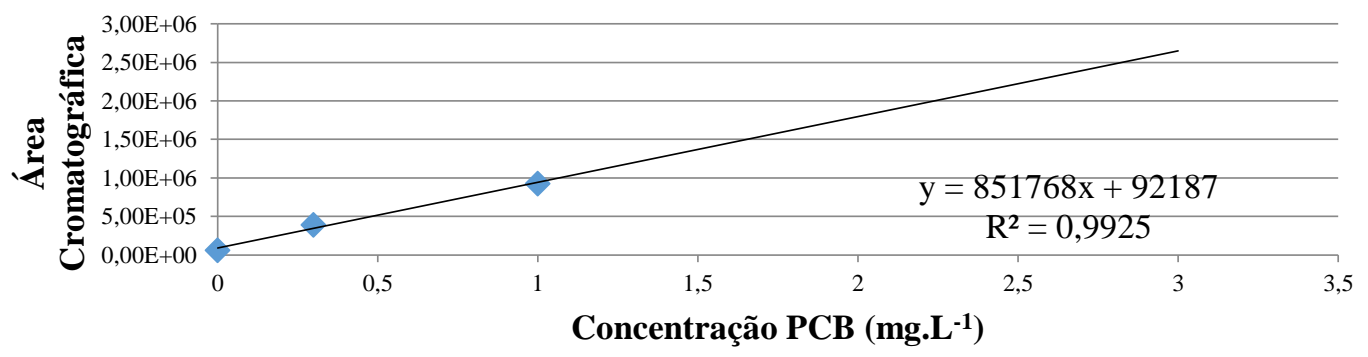

(c)

Figura A. 13 Curva de extração utilizando a técnica de SPME com Adição de Padrão nos Reatores Anóxico para o PCB 10. (a) Análise no DT0, (b) Análise no DT1 e (c) Análise no DT2. 


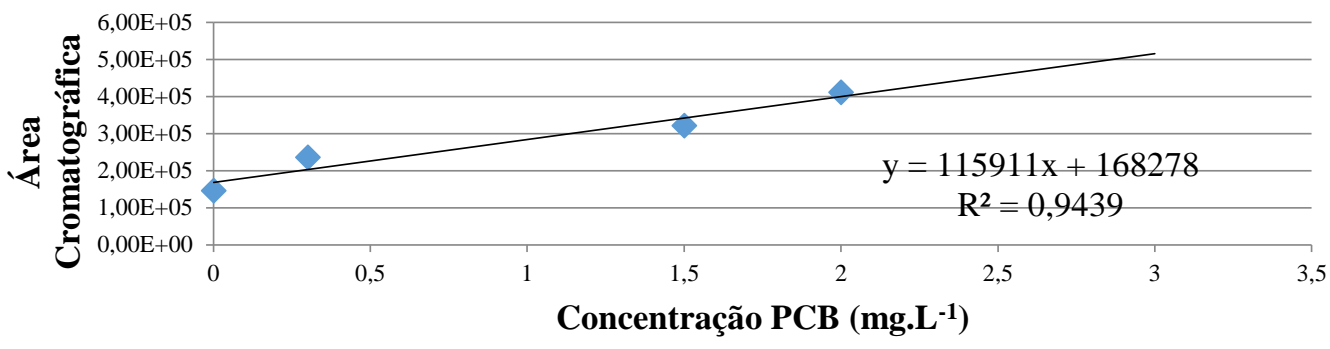

(a)

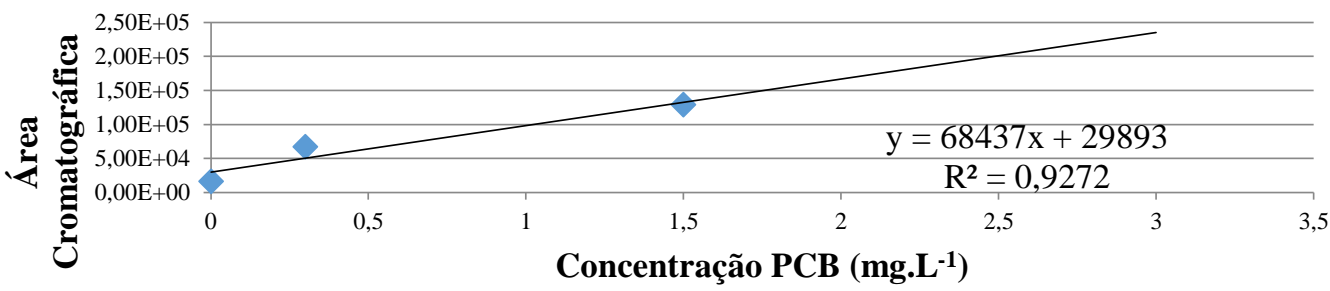

(b)

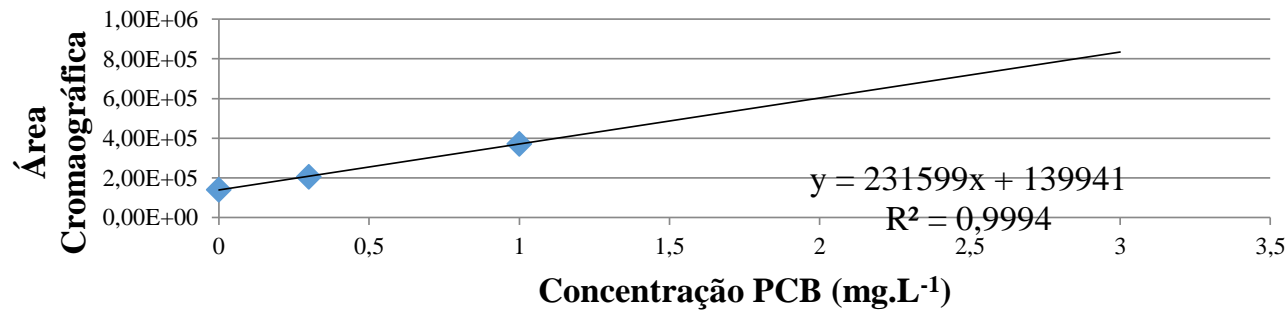

(c)

Figura A. 14 Curva de extração utilizando a técnica de SPME com Adição de Padrão nos Reatores Anóxico para o PCB 28. (a) Análise no DT0, (b) Análise no DT1 e (c) Análise no DT2. 


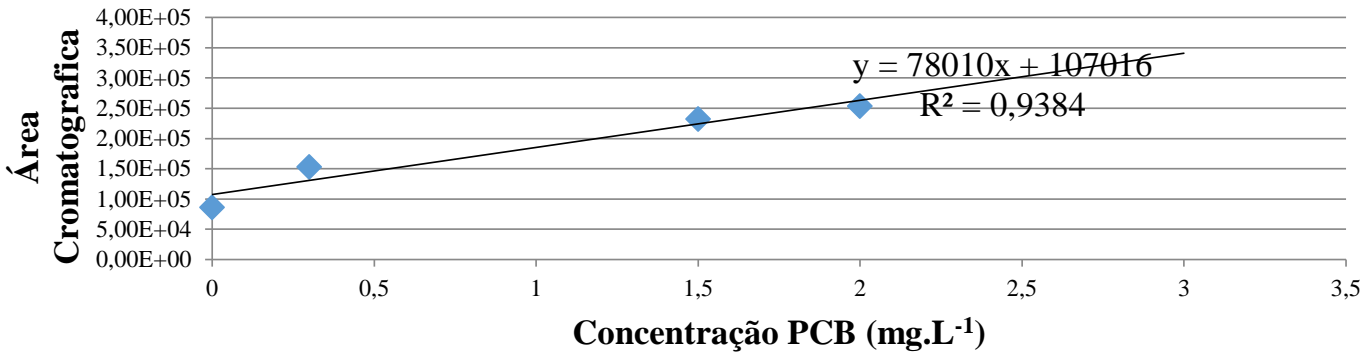

(a)

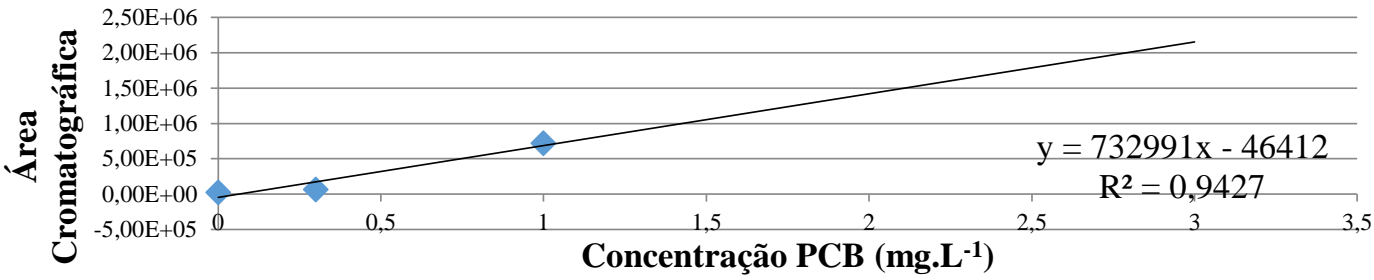

(b)

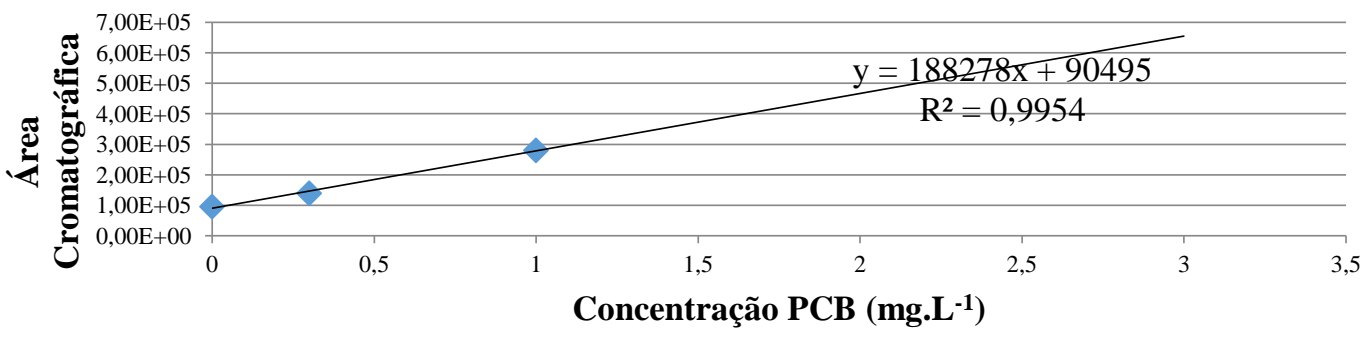

(C)

Figura A. 15 Curva de extração utilizando a técnica de SPME com Adição de Padrão nos Reatores Anóxico para o PCB 52. (a) Análise no DT0, (b) Análise no DT1 e (c) Análise no DT2. 


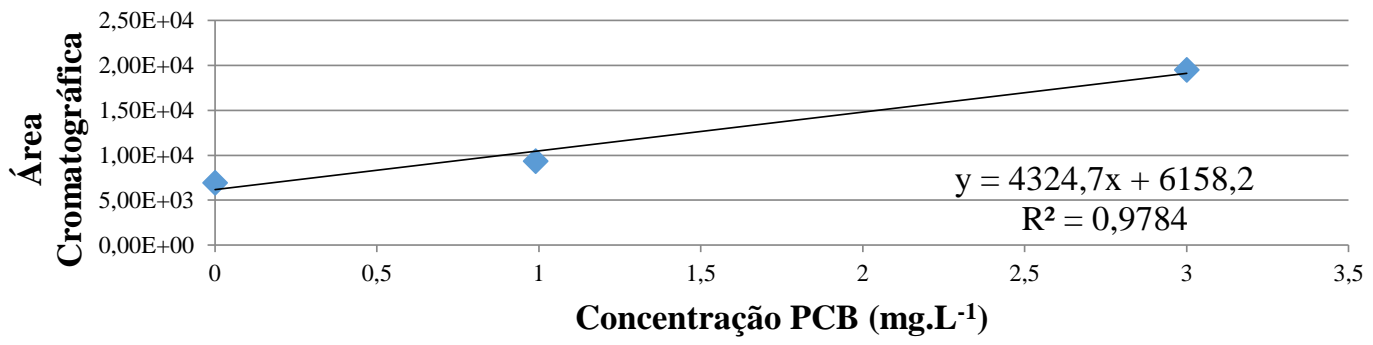

(a)

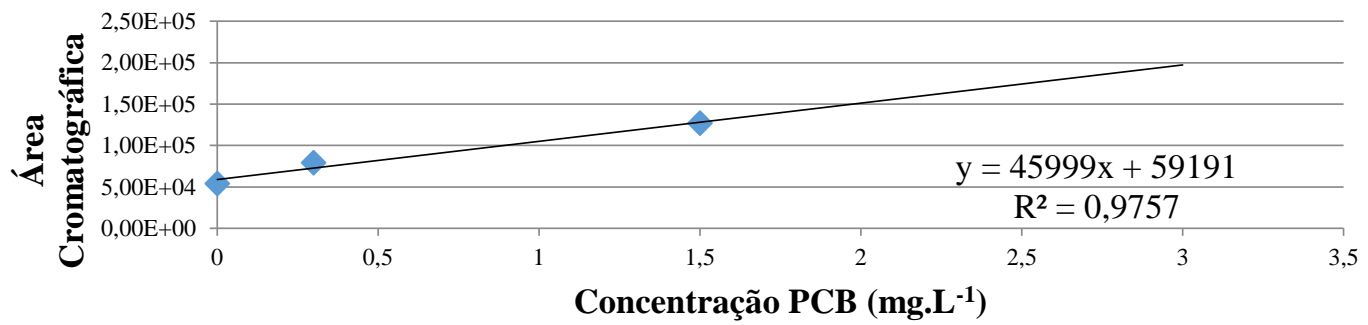

(b)

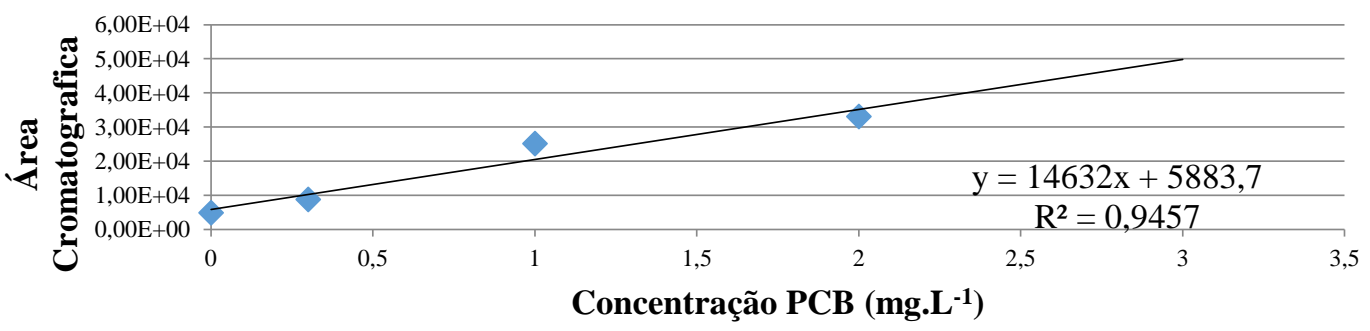

(c)

Figura A. 16 Curva de extração utilizando a técnica de SPME com Adição de Padrão nos Reatores Anóxico para o PCB 153. (a) Análise no DT0, (b) Análise no DT1 e (c) Análise no DT2. 


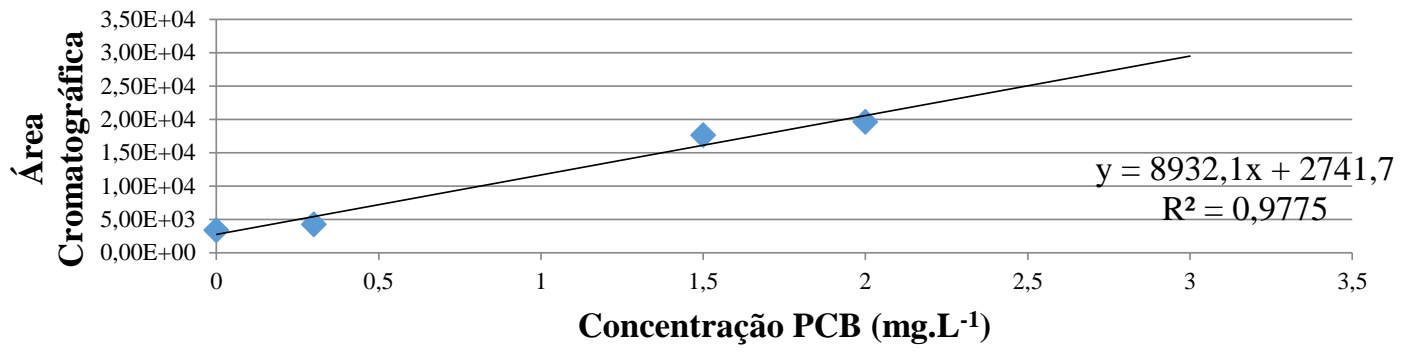

(a)

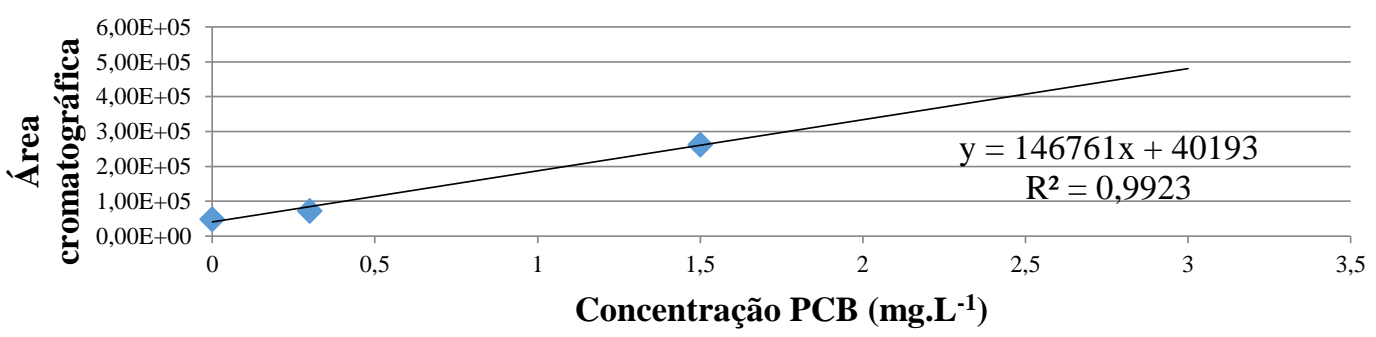

(b)

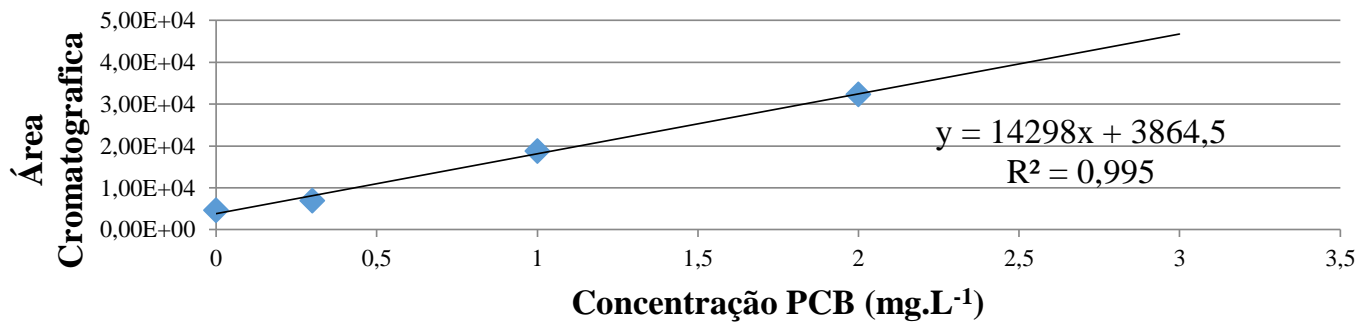

(c)

Figura A. 17 Curva de extração utilizando a técnica de SPME com Adição de Padrão nos Reatores Anóxico para o PCB 138. (a) Análise no DT0, (b) Análise no DT1 e (c) Análise no DT2. 
PCB 180

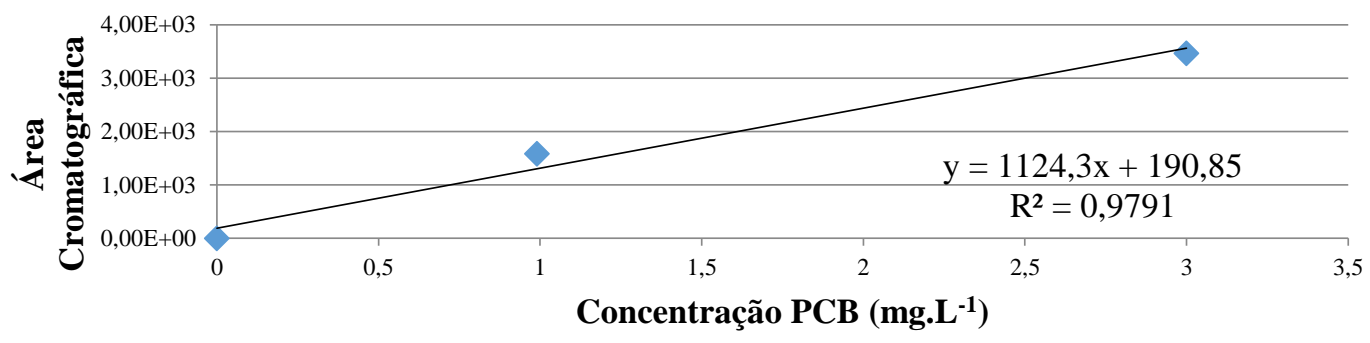

(a)

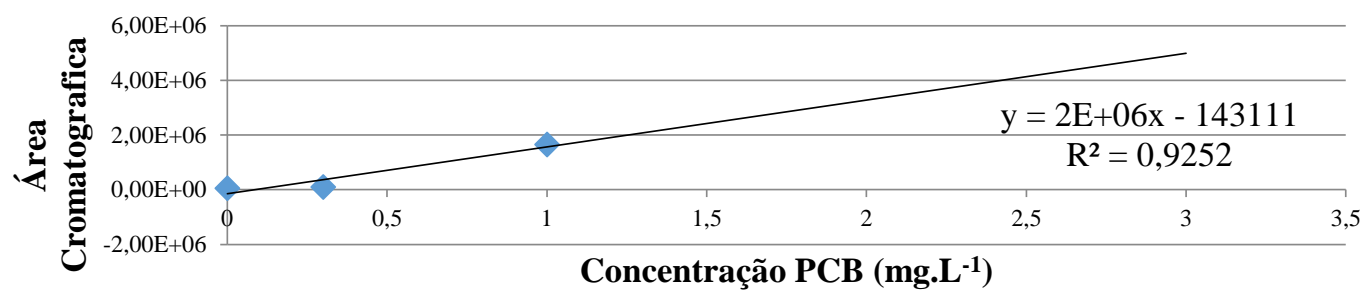

(b)

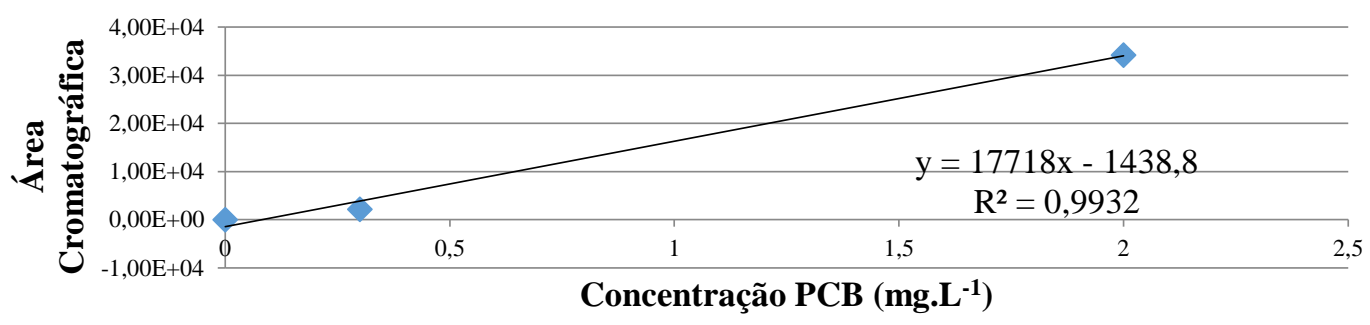

(c)

Figura A. 18 Curva de extração utilizando a técnica de SPME com Adição de Padrão nos Reatores Anóxico para o PCB 180. (a) Análise no DT0, (b) Análise no DT1 e (c) Análise no DT2. 


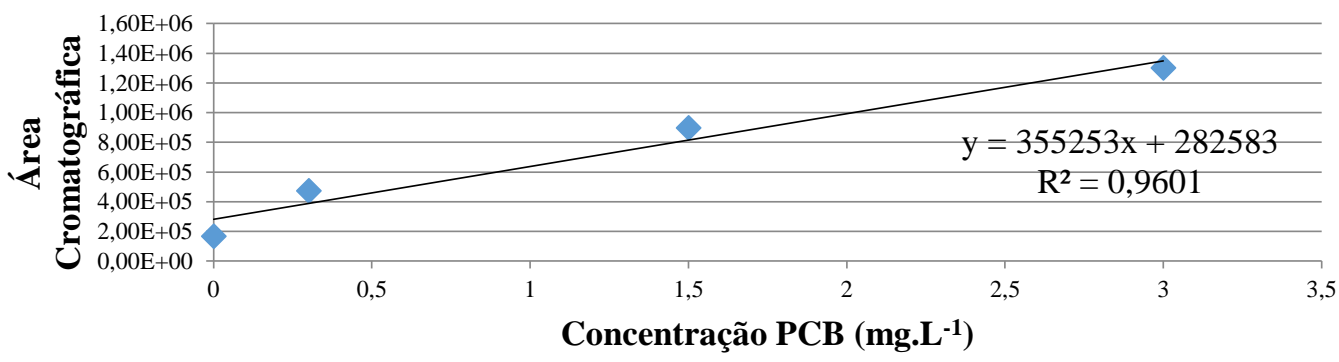

(a)

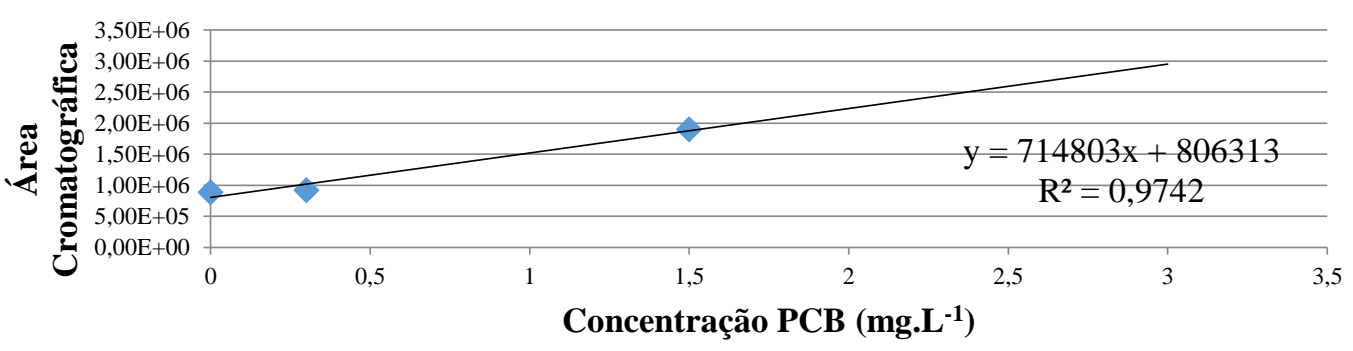

(b)

Figura A. 19 Curva de extração utilizando a técnica de SPME com Adição de Padrão nos Reatores Controle Anóxico para o PCB 10. (a) Análise no CDT0 e (b) Análise no CDT2.

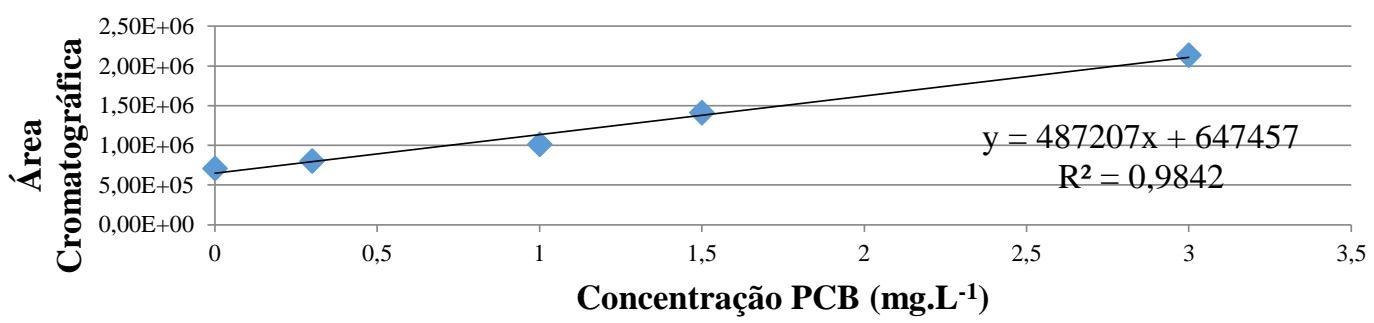

(a)

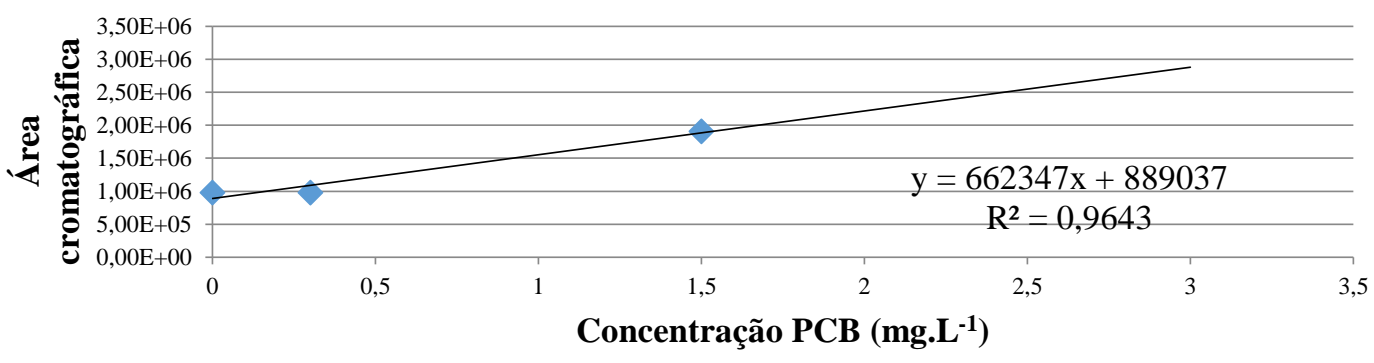

(b)

Figura A. 20 Curva de extração utilizando a técnica de SPME com Adição de Padrão nos Reatores Controle Anóxico para o PCB 28. (a) Análise no CDT0 e (b) Análise no CDT2. 


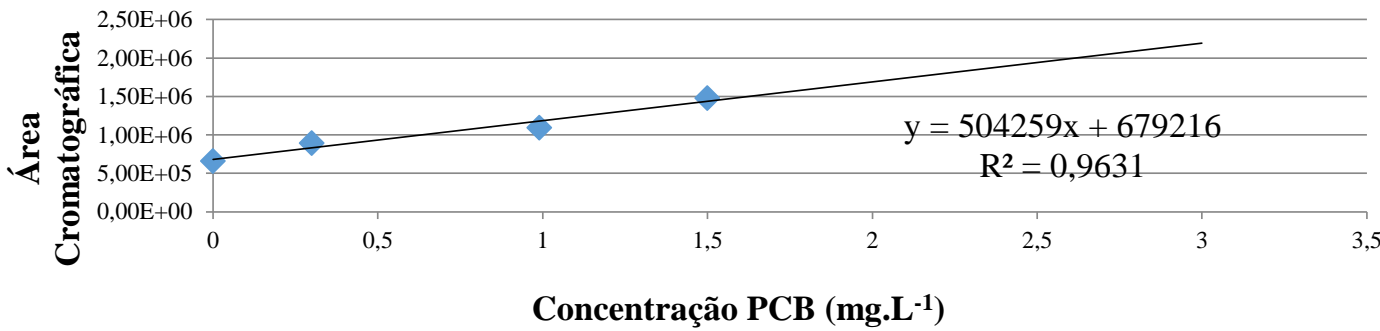

(a)

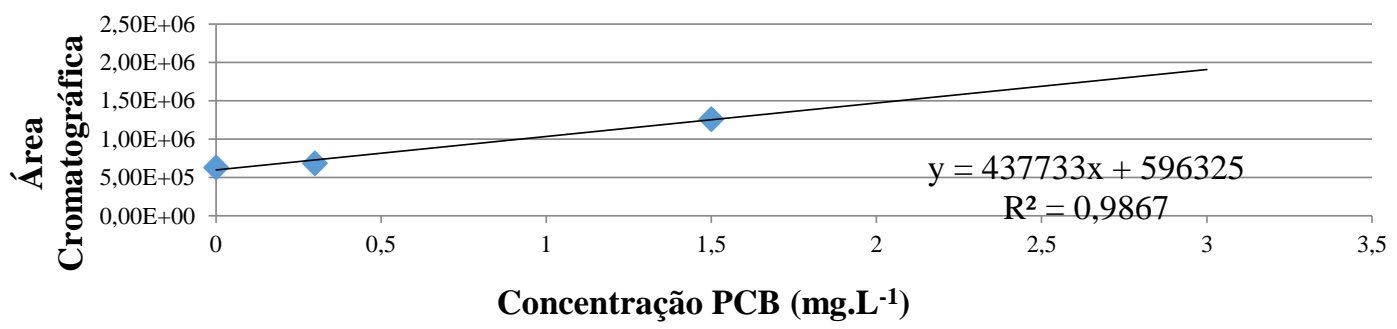

(b)

Figura A. 21 Curva de extração utilizando a técnica de SPME com Adição de Padrão nos Reatores Controle Anóxico para o PCB 52. (a) Análise no CDT0 e (b) Análise no CDT2.

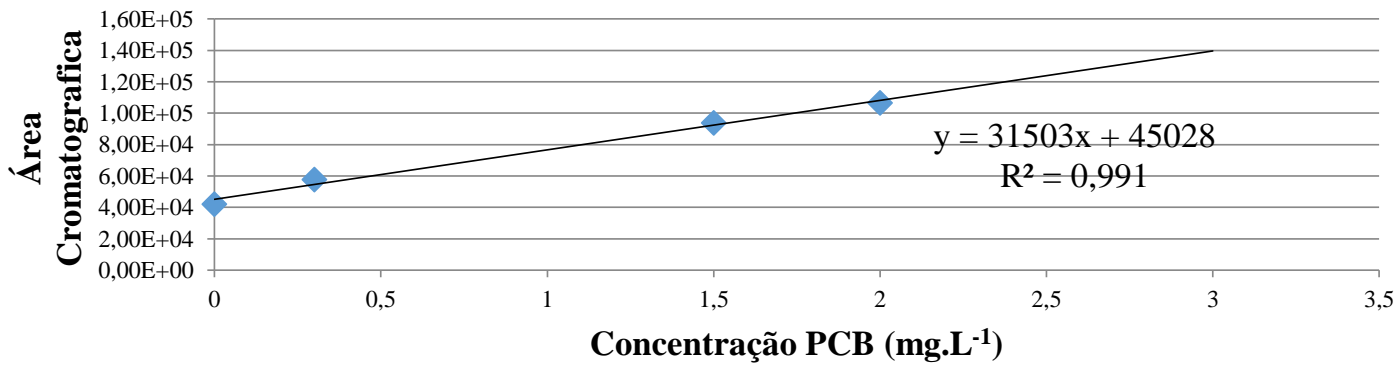

(a)

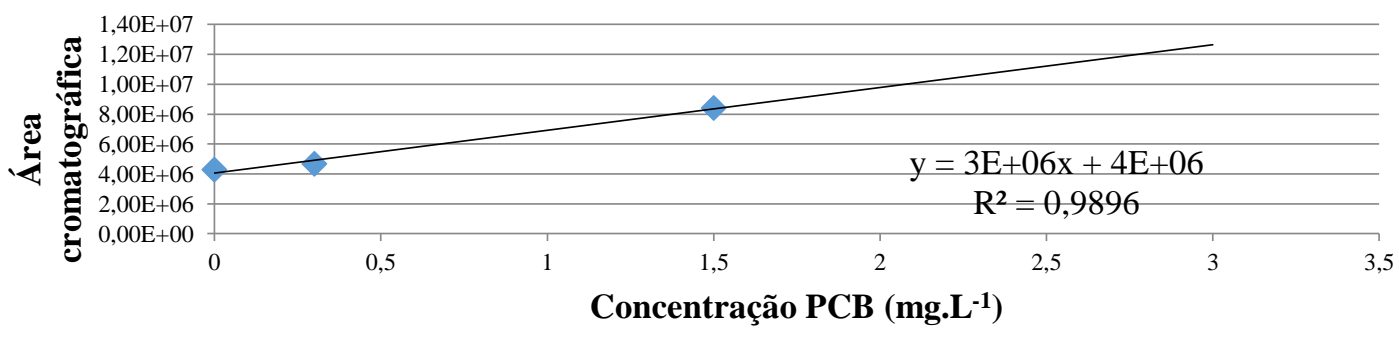

(b)

Figura A. 22 Curva de extração utilizando a técnica de SPME com Adição de Padrão nos Reatores Controle Anóxico para o PCB 153. (a) Análise no CDT0 e (b) Análise no CDT2. 


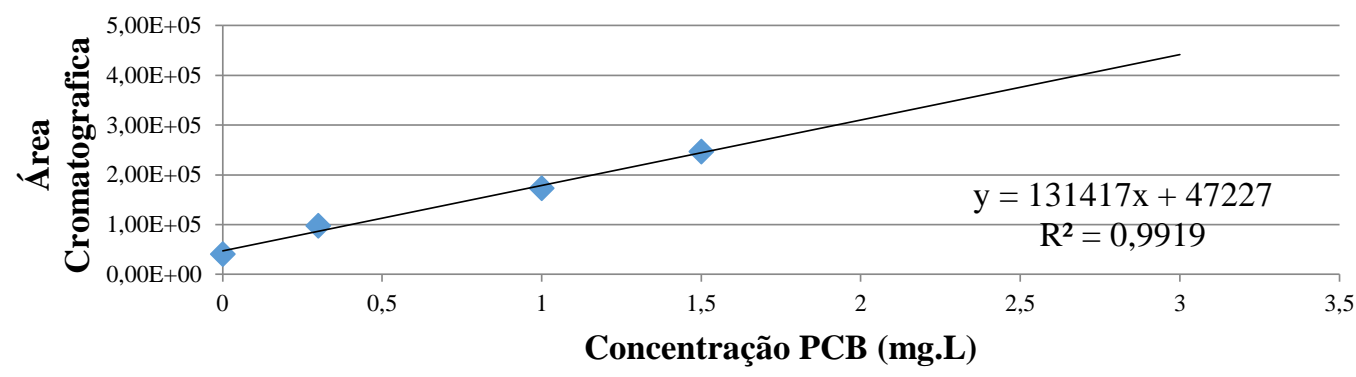

(a)

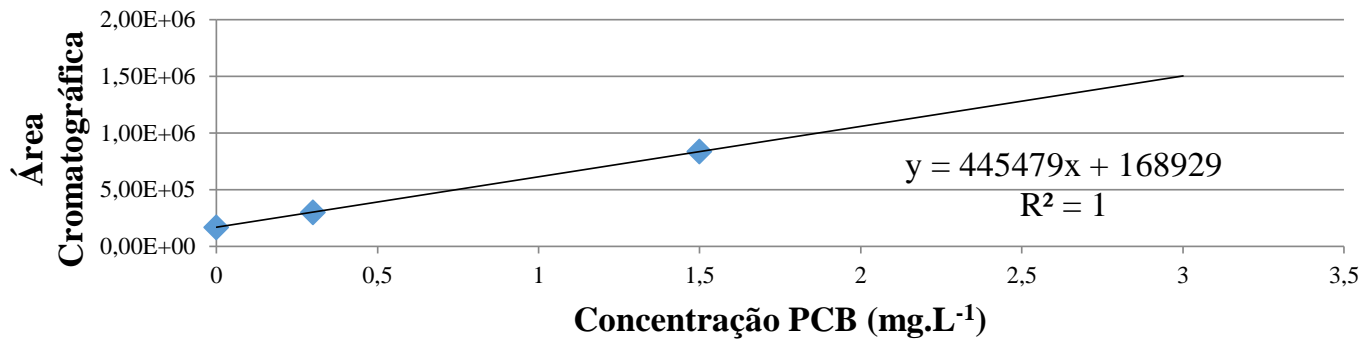

(b)

Figura A. 23 Curva de extração utilizando a técnica de SPME com Adição de Padrão nos Reatores Controle Anóxico para o PCB 138. (a) Análise no CDT0 e (b) Análise no CDT2.

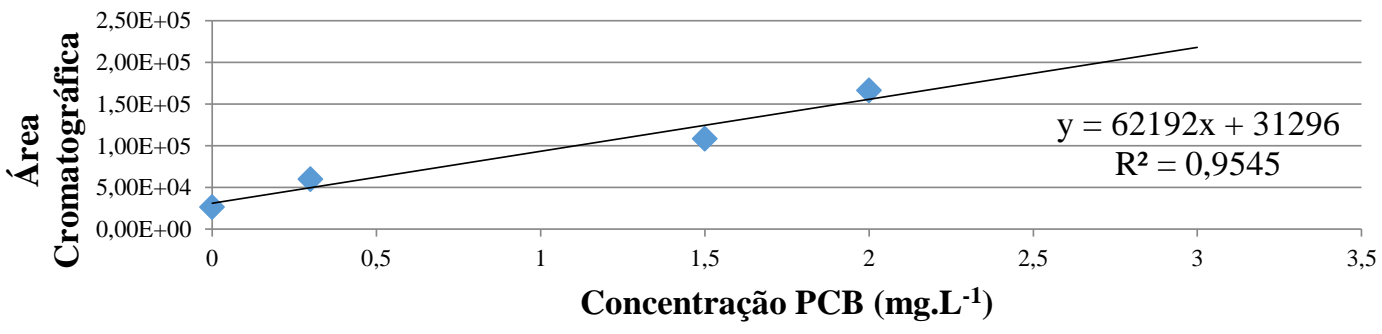

(a)

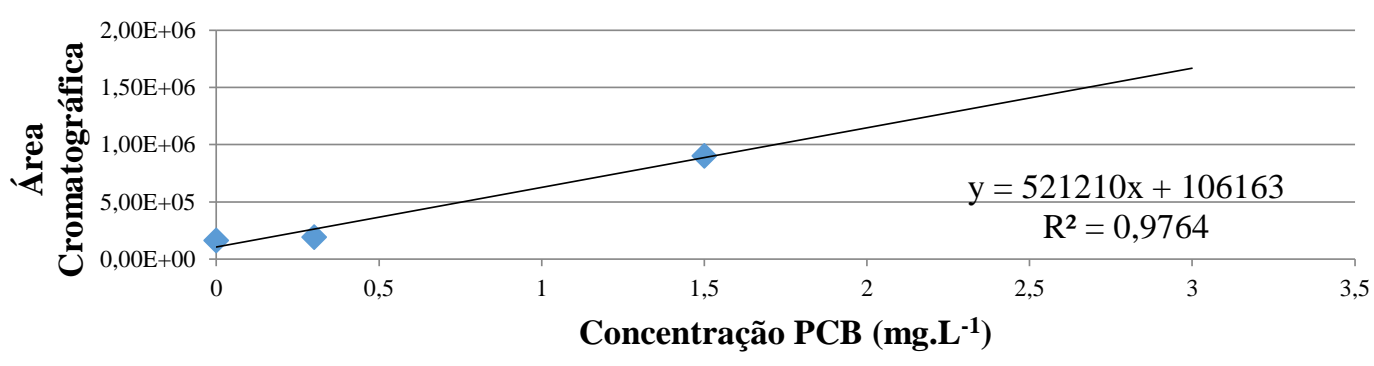

(b)

Figura A. 24 Curva de extração utilizando a técnica de SPME com Adição de Padrão nos Reatores Controle Anóxico para o PCB 180. (a) Análise no CDT0 e (b) Análise no CDT2. 
Tabela A. 1 Microrganismo do Domínio Bacteria mais abundantes no inoculo metanogênico, ou nos reatores no tempo inicial (MT0) (97\% similaridade).

\begin{tabular}{cc} 
Microrganismo & Abundância relativa \\
\hline Sulfurimonas $(\mathrm{G})$ & $26,89 \%$ \\
\hline Cloacamonas $(\mathrm{G})$ & $3,99 \%$ \\
\hline Synergistaceae $(\mathrm{F})$ & $3,27 \%$ \\
\hline Dethiosulfovibrionaceae $(\mathrm{F})$ & $2,43 \%$ \\
\hline Synesgistales $(\mathrm{O})$ & $1,94 \%$ \\
\hline Desulfovibrio mexicanus $(\mathrm{E})$ & $1,84 \%$ \\
\hline Sulfuricurvum kujiense $(\mathrm{E})$ & $1,48 \%$ \\
\hline Anaerolinaceae $(\mathrm{F})$ & $1,18 \%$ \\
\hline Syntrophus $(\mathrm{G})$ & $1,13 \%$ \\
\hline Thiobacillus $(\mathrm{G})$ & $0,95 \%$
\end{tabular}

Tabela A. 2 Microrganismos do Domínio Bacteria mais abundantes nos reatores metanogênicos no tempo final (MT2) (97\% de similaridade).

\begin{tabular}{cc} 
Microrganismo & Abundancia relativa \\
\hline Thermotogaceae $(\mathrm{F})$ & $29,59 \%$ \\
\hline Sedimentibacter $(\mathrm{G})$ & $12,26 \%$ \\
\hline Anaerolinaceae $(\mathrm{F})$ & $3,86 \%$ \\
\hline Synergistaceae $(\mathrm{F})$ & $2,98 \%$ \\
\hline Pseudomonas $(\mathrm{G})$ & $2,53 \%$ \\
\hline Anaerolinaceae $(\mathrm{F})$ & $2,43 \%$ \\
\hline Sulfuricurvum kujiense $(\mathrm{E})$ & $2,19 \%$ \\
\hline Synesgistales $(\mathrm{O})$ & $1,68 \%$ \\
\hline Dethiosulfovibrionacea $(\mathrm{F})$ & $1,31 \%$ \\
\hline Dethiosulfovibrionaceae $(\mathrm{F})$ & $0,89 \%$
\end{tabular}


Tabela A. 3 Microrganismo do Domínio Bacteria mais abundantes no inoculo desnitrificante, ou nos reatores no tempo inicial (DT0) (97\% similaridade).

\begin{tabular}{cc} 
Microrganismo & Abundância relativa \\
\hline Kouleothrix $(\mathrm{G})$ & $15,2 \%$ \\
\hline Clostridiaceae $(\mathrm{F})$ & $9,1 \%$ \\
\hline Chitinophagaceae $(\mathrm{F})$ & $6,7 \%$ \\
\hline Hyphomonadaceae $(\mathrm{F})$ & $5,7 \%$ \\
\hline Fimbriimonas $(\mathrm{G})$ & $4,5 \%$ \\
\hline Chloracidobacteria $(\mathrm{C})$ & $4,4 \%$ \\
\hline Prosthecobacter $(\mathrm{G})$ & $4,0 \%$ \\
\hline Rhizobiales $(\mathrm{O})$ & $3,9 \%$ \\
\hline Thermomonas $(\mathrm{G})$ & $3,7 \%$ \\
\hline Caldilineaceae $(\mathrm{F})$ & $3,5 \%$
\end{tabular}

Tabela A. 4 Microrganismo do Domínio Bacteria mais abundantes no inoculo desnitrificante, ou nos reatores no tempo final (DT2) (97\% similaridade).

\begin{tabular}{cc} 
Microrganismo & Abundância relativa \\
\hline Aeromonadaceae $(\mathrm{F})$ & $28,4 \%$ \\
\hline Lutispora $(\mathrm{G})$ & $8,9 \%$ \\
\hline Sedimentibacter $(\mathrm{G})$ & $8,0 \%$ \\
\hline Thermotogaceae $(\mathrm{F})$ & $6,1 \%$ \\
\hline Fimbriimonas $(\mathrm{G})$ & $3,9 \%$ \\
\hline Anaerolinaceae $(\mathrm{F})$ & $2,6 \%$ \\
\hline Porphyromonadaceae $(\mathrm{F})$ & $2,4 \%$ \\
\hline Hyphomonadaceae $(\mathrm{F})$ & $2,4 \%$ \\
\hline Stenotrophomonas acidaminiphila $(\mathrm{E})$ & $2,1 \%$ \\
\hline Chitinophagaceae $(\mathrm{F})$ & $1,1 \%$
\end{tabular}

